UNIVERSIDADE DE SÃO PAULO

FACULDADE DE ECONOMIA, ADMINISTRAÇÃO E CONTABILIDADE Departamento de Administração

\title{
INDICADORES EMPRESARIAIS DE QUALIDADE DE VIDA NO TRABALHO
}

esforço empresarial e satisfação dos empregados no ambiente de manufaturas com certificação ISO 9000

\begin{abstract}
Ana Cristina Limongi França
orientador: Prof. Dr. Lindolfo Galvão de Albuquerque

Tese apresentada à Faculdade de Economia, Administração e Contabilidade da Universidade de São Paulo para obtenção do título de Doutor em Administração.
\end{abstract}

São Paulo

1996 
Aos meus filhos Caio Augusto e Ana Alice pelo carinho e maturidade constantes

Aos meus pais Maria Thereza (in memorian), Rubens e irmãos: Ana Isabel, Antonio de Sant'Ana, Ana Carlota, Vicente de Paulo, Stefan, Ana Judite e Carlos Otávio pelos muitos exemplos de luta e jovialidade

A Profa. Dra. Maria Tereza Leme Fleury pela admiração que tenho como pessoa e como profissional 


\section{AGRADECIMENTOS}

Agradeço com muito carinho e reconhecimento às pessoas aqui relacionadas, por todas as oportunidades de aprendizado para elaboração desta tese.

Ao Prof. Dr. Lindolfo Galvão de Albuquerque, meu orientador, pela confiança, otimismo e respeito profissional o que gerou um processo agradável de convivência e discussão de dados e conceitos.

Ao Prof. Dr. Roberto Sbragia por todas as contribuições metodológicas e conceituais, paciente acompanhamento e respeitosa amizade.

Aos colegas professores doutores Mario de Biasi pela elaboração do cartograma, Ademir Antonio Ferreira, Ana Akemi Ikeda, Celso Grisi, Edgar Monforte Mello, Daniel Augusto Moreira, Claudio Felizoni, Geraldo Luciano Toledo, Fauze Mattar, Gilberto Teixeira, Joel Dutra, Antonio Carlos Aidar Sauaia, Dante Martolucci, José Augusto Gualhardi, Hélio e Odete Teixeira, Marcos Cortez Campomar, Maria Tereza Leme Fleury, Marisa Eboli, Maria Aparecida Gouveia, Osvaldo Scaicco, Rosa Maria Fischer, Reinaldo, Sigfrield Bender, René Mendes, José Joaquim do Amaral Ferreira, Pedro Luiz de Oliveira Costa Neto, Eda Conte Fernandes e Yuchi Tsukamoto, pelas preciosas contribuições.

Ao Paulo Mendes, que cumpriu com sabedoria a tarefa de estagiário e aos meus alunos pelas contínuas oportunidades inesperadas de reflexão.

Aos colegas do pós-graduação, especialmente ao Sandro. Ao pessoal da FIA e da Administração da FEA, que me apoiou em diversos momentos de conciliação de atividades, principalmente Ivanete, Elton, Magda, Miriam, Regina, Sheyla, Denise, Lúcia, Elaine, Valéria, Ana Cristina, Cida, Heloisa e Fabiana.

A Luciana Dias Rickes, Daniela Ozella Fonseca, Dulcinéia - Chefe da Biblioteca, Eliana, Andréa e Mônica, da Assestec, que deram todo suporte, de maneira muito dedicada. Ao Delfim Galizi Domingues pela rapidez e criatividade na elaboração dos gráficos. 
A Sigrid, da Siemens, Ricardo de Marchi, Luiz Antônio, da Plascar, Peixe da Mercedes-Benz, Francesco de Cicco, Francisco da Walita, Massarenti, da Telesp e Célia da CPFL pelas sugestões.

A Reni Chehter Berezini que não mediu esforços para dar suporte estatístico nos desafios da pesquisa. Agradeço também ao professor Canton pelo esclarecimento de dúvidas.

Um agradecimento especial à competência e dedicação de Adilson Souza Gobbes e Ailton Bonfim pelo apoio.

Aos amigos Enilde Machado da Costa, Octávio Jordão, Davida e Avelino Luiz Rodrigues, Valda Bernardes, Fernando Toledo Ferraz, Leni Sato, Jorge Matsubara, Rosa Nagi, Rosa Spinelli, Eva, Sandra Márcia Motta Liger, Nilo Torturella, Mayza Rocha - pelas traduções de emergência, Renato Skaf dos Santos e Katy Beraldo pelo apoio, companhia e carinho.

Muito especialmente agradeço aos diretores e gerentes que permitiram a realização das atividades de campo nas suas empresas, porque sem eles este não seria possível.

Finalmente, agradeço aos meus filhos queridos Caio Augusto e Ana Alice, por terem ajudado, criado os desenhos e compartilhado muitos momentos difíceis destes anos de pesquisa. 


\section{RESUMO}

Este trabalho examina Qualidade de Vida no Trabalho nas manufaturas, de médio porte que obtiveram certificação ISO 9000. Nosso principal objetivo foi investigar as prováveis relações entre esforço da empresa e satisfação dos empregados através de indicadores empresariais selecionados com critérios da abordagem biopsicossocial. O método de pesquisa foi estudo de campo, com o modelo de variáveis dependentes e independentes. Os dados foram coletados em 26 empresas e 446 questionários, na Região de São Paulo.

Os resultados demonstram inicialmente comparações através de análise exploratória entre gerência de recursos humanos e empregados. A seguir, levantaram-se fatores de satisfação dos empregados, quais sejam: atuação organizacional, necessidades biológicas, inclusão social, prestação de serviços; e fatores de esforço das empresas: imagem, desenvolvimento profissional, administração de recursos humanos, saúde e ética, demandas legais e reposição de energias.

Através de análise de conglomerados foram obtidos perfis de atitudes dos empregados. Os perfis são diferenciados entre realização, desconfiança ou crítica à empresa. Finalmente, obtivemos resultados sobre tipos de gestão. Os tipos identificados foram estruturado, reativo e aleatório. Relacionando-se esses tipos de gestão e perfis dos empregados, constatou-se que a satisfação dos empregados localiza-se mais na imagem da empresa e em programas de atendimento a saúde e benefícios, que no tipo de gestão. 


\section{ABSTRACT}

This work deals with Life Quality at Work at medium-sized manufacturers that had been awarded ISO 9000 certificate. We targeted investigating the potential relationship between company's effort and employee's satisfaction through the selected company's indicators based on criteria of the bio-psychosocial approach. Research method was the field study with the model of dependent and independent variables. Data were collected at 26 companies by 446 questionnaires in the São Paulo Region.

Results show first comparisons through exploratory analysis of human resources management and employees. Following, employee's satisfaction factors were identified as follows: organizational acting, biological needs, social integration, service rendering; so were the company's effort factors: image, professional development, human resources management, health and ethics, legal actions and energy recovery.

By means of a cluster analysis, the employee's attitude profile was obtained. They were made distinct among accomplishment, discredit or criticism about the company.

Finally, we have obtained results related to kinds of management. Identified kinds were structured, reactive and random. After relating these kinds of management and employee's profiles, we could find out that employee's satisfaction is based more on the company's image and on medical services and benefits than on the kind of management. 


\section{Introdução}

A globalização econômica tem levado as empresas a adotar mudanças radicais, como flexibilidade de produção, custos enxutos, decisões rápidas, atitudes assertivas, ausência de desperdício, impactos tecnológicos.

Investigar qualidade de vida no trabalho em cenário de competitividade empresarial pode representar, à primeira vista, um problema de caráter contraditório. A contradição parece estar nas decisões em que se avalia se é possível privilegiar a pessoa e a empresa com os mesmos resultados de produtividade e qualidade.

Nas empresas, vivem-se constantes esforços de mudanças que mobilizam pessoas: no entanto, ações sobre as condições de trabalho raramente recebem investimento específico. Este fato fragiliza as pessoas e freqüentemente compromete os projetos da empresa, em termos de continuidade, de otimização das metas e o processo de aprendizado organizacional. Externamente, a busca é a prestação de serviços para o cliente e a conquista do mercado. No ambiente da empresa, este cenário é composto por clientes internos, que, para responderem ao mercado, devem apresentar atitudes, conhecimentos e operações com todo potencial biopsicossocial preservado e continuamente aperfeiçoado. 
Esta intensa variedade de pressões cria um cenário dinâmico e exigente para as organizações que pretendem sobreviver nas próximas gerações. As pessoas nesse cenário têm sido submetidas a desafios intensos, que, de um lado, ameaçam a estabilidade e o conhecimento adquirido, de outro, têm sido a grande oportunidade de mudança, como modernização, evolução quanto à performance, maturidade crítica, criação de novos paradigmas e valores de preservação, qualidade de compromisso e autonomia profissional.

Obter a certificação não significa necessariamente que a empresa conseguiu maior qualidade em seus produtos e serviços, nem em qualidade de vida no trabalho. As mudanças têm sido realizadas a curto prazo e muitas vezes com inovações que podem ser alavancadas para melhores condições de vida no trabalho.

Por pressão, falta de técnicas comportamentais ou estilo de gestão, o foco dos sistemas de qualidade tem sido os processos de produção e preparação da documentação.

Pouco tem sido construído na cultura organizacional sobre a valorização do bem-estar no trabalho. Exigências disciplinares pouco têm que ver com o desempenho global da empresa. As formas de proteção dos riscos ocupacionais são estabelecidas mais para atender a pressão da legislação do que promover a saúde. A responsabilidade social fica restrita ao estilo da alta direção e das pressões sindicais.

A ênfase na subsistência, como propulsora do compromisso com o trabalho, algumas vezes tem sido substituída pela supervalorização do trabalho. O 
significado do trabalho como fonte de enriquecimento e realização existencial (Harman e Hormann, 1990:100) é algo que se aceita como valor, mas se pratica pouco como política de recursos humanos.

A necessidade humana de performance capacitada e saudável é obtida de forma casual. O gerenciamento da qualidade de vida no trabalho tem sido compreendido de forma parcial e incompleta. A atuação da qualidade voltada para pessoas freqüentemente traz um referencial assistencialista, como benemerência ou, simplesmente, ações para Qualidade de Vida no Trabalho que são ignoradas nas políticas das empresas.

Existem dificuldades reais de gerenciamento da Qualidade de Vida no Trabalho, como a heterogeneidade de perfis individuais e socio-econômicos das pessoas que formam a força de trabalho de cada empresa, a natureza dos impactos dos sistemas de qualidade na performance de bem-estar e saúde da empresa em seus níveis individual, grupal e organizacional, com impactos políticoorganizacionais.

A escolha do tema Qualidade de Vida no Trabalho como linha de pesquisa é o caminho de volta percorrido durante a dissertação de mestrado sobre manifestações psicossomáticas e ambiente organizacional. Agora, na humanização do trabalho, propusemo-nos entender com maior profundidade o que e como estão sendo gerenciados os programas e as ações que geram melhores condições de vida humana no trabalho. O paradigma é que o ser humano em condições favoráveis à expressão de sua humanidade gera resultados visíveis na organização como um todo. 
Os conceitos tratados na fundamentação teórica são:

Qualidade de vida no trabalho: evolução histórica, demandas socioeconômicas, abordagens, revisão histórica dos conceitos de relações de trabalho, administração de recursos humanos.

Ações empresariais voltadas para Qualidade de Vida no Trabalho: critérios adotados, programas existentes nas empresas, fenômenos humanos e organizacionais: abordagem biopsicossocial.

Indicadores de qualidade de vida, abordagem biopsicossocial, Índice de Desenvolvimento Humano e outros indicadores que contribuiram para a construção do desenho do problema.

A competitividade: fundamentos sociais das empresas, a era da qualidade, demandas estratégicas da gestão de recursos humanos, pressão empresarial em busca da competitividade.

Qualidade e Certificação ISO 9000: Histórico, caracterização, abrangência e objetivos da certificação ISO 9000, Prêmio Nacional da Qualidade - PNQ, mitos e problemas da certificação. Finalizando uma breve abordagem sobre as tendências de certificação.

A metodologia de coleta de dados adotada foi pesquisa de campo. O problema foi desenhado através da análise de problemas organizacionais, e as variáveis escolhidas foram esforço da empresa x satisfação dos empregados em ações e programas de qualidade de vida no trabalho.

A escolha dos procedimentos de campo, de aplicação dos questionários na própria empresa, visou ter contato direto com os empregados em seu ambiente de trabalho, durante o autopreenchimento dos dados. 
A análise dos resultados foi exploratória, dado o estágio inicial de pesquisas no tema. Um segundo conjunto de análise apresenta tratamentos estatísticos de análises univariadas e multivariadas. Pretendemos obter dados de análise fatorial, conglomerados de perfis dos empregados e índices específicos de estruturação da gestão da Qualidade de Vida no Trabalho das empresas.

A metodologia de análise dos resultados será essencialmente exploratória, sem no entanto desprezar a contribuição instigadora de prováveis relações e explicações das ações de qualidade de vida no trabalho. 
Organizamos esses temas de acordo com a ilustração a seguir.

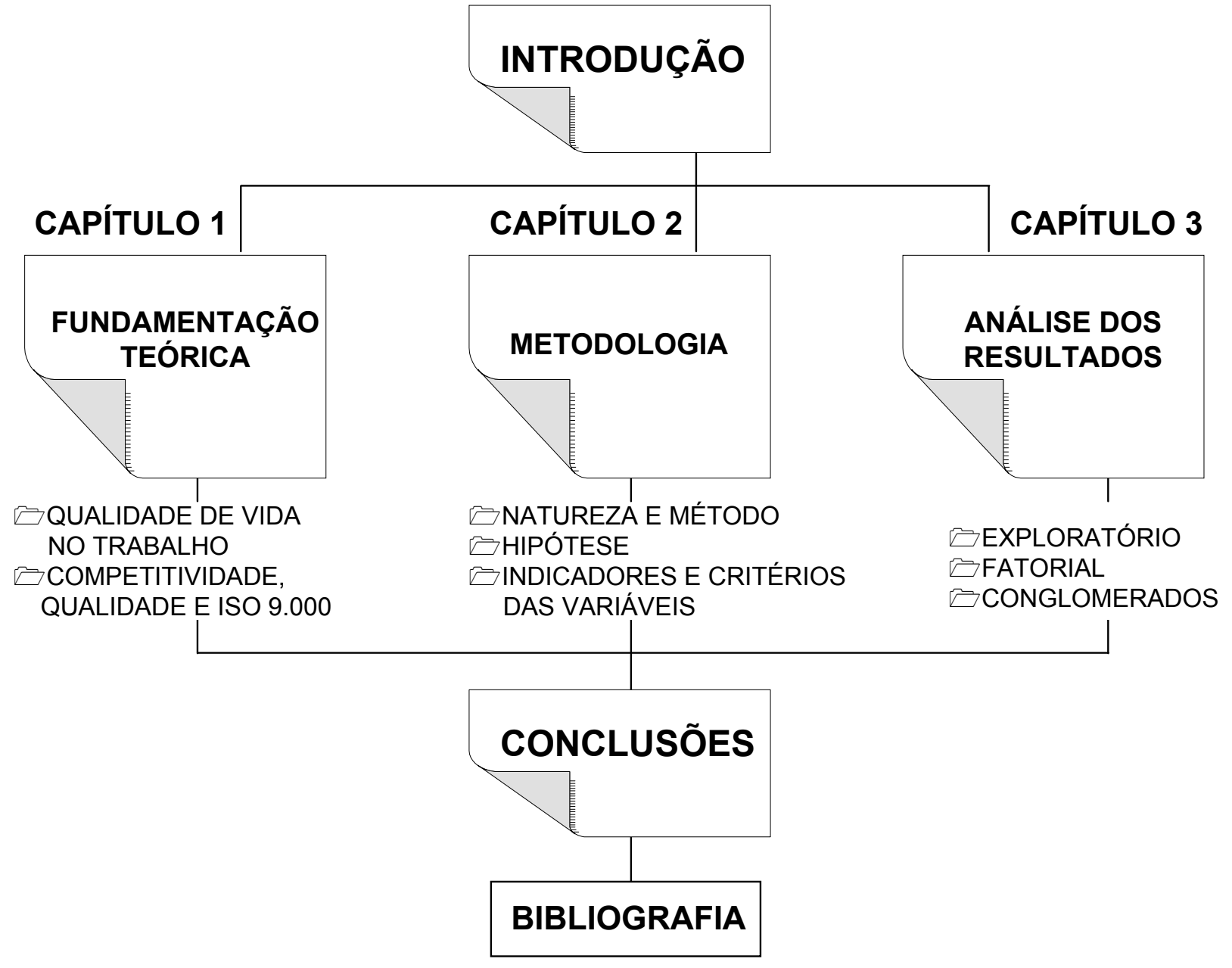

Estrutura do texto

Algumas contribuições foram idealizadas como resultado do esforço científico. Inicialmente, este estudo pretende situar, no mesmo grau de importância de outras políticas e ações empresariais, a gestão da qualidade de vida no trabalho associada à competitividade empresarial, mas com alma. 
Esta busca atende às tendências de humanização no trabalho, em que diante da complexidade e da crescente presença de tarefas que exigem raciocínio abstrato e atenção seletiva, cada pessoa deve ter suportes sociais de bem-estar e capacitação ocupacionais.

Os resultados deverão contribuir para instrumentalização da implementação de ações, políticas e programas dentro de critérios da abordagem biopsicossocial.

Espera-se também revelar e aprofundar a compreensão sobre valores culturais associados à oposição entre expectativas individuais e necessidades de resultados da empresa.

Algumas características, que podem levar a limitações deste tipo de estudo, referem-se a:

- Práticas de gestão de recursos humanos pouco consolidadas na grande maioria das empresas brasileiras.

- Ambiente mercadológico em franco crescimento com novas exigências associadas a requisitos de qualidade.

- Medo dos funcionários de expressar a real opinião, em função do crescente desemprego.

- Falta de hábito de pesquisa junto aos funcionários, que gera necessidade de cuidados das gerências em levantar expectativas.

Em decorrência da complexidade e de certa tradição em tratar o tema de forma mais individualizada e subjetiva, há mais perguntas do que respostas. Por isso espera-se que as experiências aqui relatadas sejam uma contribuição correta para novas perspectivas de gestão no que se refere à valorização da condição humana no trabalho. 


\section{1 \\ FUNDAMENTAÇÃO TEÓRICA}

1.1 QUALIDADE DE VIDA NO TRABALHO 9

$\begin{array}{ll}\text { 1.1.1 Conceitos } & 9\end{array}$

$\begin{array}{ll}\text { 1.1.2 Visão biopsicossocial } & 12\end{array}$

1.1.3 Abordagens sobre a Qualidade de Vida no Trabalho 20

$\begin{array}{ll}\text { 1.1.4 Contribuição das ciências } & 23\end{array}$

1.2 BASES CONCEITUAIS DOS INDICADORES DAS VARIÁVEIS 25

1.2.1 Construção dos indicadores 29

1.2.2 Importância da Qualidade de Vida no Trabalho 36

1.2.3 Qualidade de Vida no Trabalho no Brasil 40

1.2.4 Fenômenos humanos e organizacionais 45

1.3 COMPETITIVIDADE, QUALIDADE E ISO 9000

1.3.1 Competitividade: da sobrevivência às implicações éticas 58

1.3.2 Gurus da qualidade: idéias e conceitos 66

$\begin{array}{ll}\text { 1.3.3 Sistema de certificação } & 72\end{array}$

1.3.4 Visão crítica da gestão de recursos humanos 82

$\begin{array}{ll}\text { 1.3.5 Ambiente manufatura } & 87\end{array}$ 


\subsection{QUALIDADE DE VIDA NO TRABALHO}

"O mais valioso de todo capital é o que é investido em seres humanos."

Alfred Marshall

\subsubsection{Conceitos}

Qualidade de Vida no Trabalho é considerada neste estudo o conjunto das ações de uma empresa que envolvem a implantação de melhorias e inovações gerenciais, tecnológicas e estruturais no ambiente de trabalho. Portanto, o foco proposto é qualidade de vida no trabalho como ferramenta gerencial construída na cultura organizacional.

As demandas de Qualidade de Vida no Trabalho surgiram há mais de duas décadas com os conceitos em que são trabalhados hoje nas empresas e junto aos cientistas. Os cientistas franceses trazem uma contribuição metodológica voltada para a criação do espaço coletivo, conscientização e participação nas decisões da empresa sobre condições ergonômicas e de gestão mais participativa (especialmente Dejours e seguidores).

Além da participação, outros processos foram estudados em linha de pesquisa de qualidade de vida. Em estudos na Volvo sueca, Werther e Davis (In Fernandes, 1988:7) enfatizam a valorização do ambiente mais humano de trabalho, com base no desenho da planta e dos cargos. Alvesson (1987) cita três pontos-chave da moderna vida no trabalho: autodeterminação versus controle, 
monotonia versus variabilidade e demanda qualificada. Estudos e experiências documentadas demonstram uma tendência de mapear incidentes críticos e identificar indicadores de stress visando ao Wellness - bem-estar -, para posterior controle e conseqüente conforto físico, elevação da auto-estima e produtividade do grupo pesquisado.

Vários autores voltados para estudos do comportamento organizacional, promoção da saúde, patologia do trabalho e, mais recentemente, programas de qualidade total têm-se dedicado ao exame da qualidade de vida no trabalho. De forma geral, observam-se conceitos de Qualidade de Vida no Trabalho - QVT, com os seguintes enfoques: (a) grau de satisfação da pessoa com a empresa; (b) condições ambientais gerais; (c) promoção da saúde. Ao revisar a bibliografia, selecionamos no Quadro 1.1 alguns desses conceitos.

\section{Quadro 1.1 Conceitos em Qualidade de Vida no Trabalho}

\begin{tabular}{|c|c|c|}
\hline Autor & Definição & Ênfase \\
\hline Drucker, 1981 & $\begin{array}{l}\text { Avaliação qualitativa da qualidade relativa das } \\
\text { condições de vida, incluindo-se atenção aos } \\
\text { agentes poluidores, barulho, estética, } \\
\text { complexidade etc. }\end{array}$ & $\begin{array}{l}\text { Responsabilidade social da } \\
\text { empresa nos movimentos sociais, } \\
\text { culturais e políticos. }\end{array}$ \\
\hline Walton, 1973 & $\begin{array}{l}\text { Atendimento de necessidades e aspirações } \\
\text { humanas, calcado na idéia de humanização e } \\
\text { responsabilidade social da empresa }\end{array}$ & $\begin{array}{l}\text { Humanização e responsabilidade } \\
\text { social, com foco no poder da } \\
\text { empresa. }\end{array}$ \\
\hline Fernandes, 1992 & $\begin{array}{l}\text { Conjunto de fatores que, quando presentes } \\
\text { numa situação de trabalho, tornam os cargos } \\
\text { mais satisfatórios e produtivos, incluindo } \\
\text { atendimento de necessidades e aspirações } \\
\text { humanas. }\end{array}$ & Humanização do cargo. \\
\hline
\end{tabular}


(continuação)

Autor

Definição

Ênfase

\begin{tabular}{|c|c|c|}
\hline Werther \& Davis, 1983 & $\begin{array}{l}\text { Esforços para melhorar a qualidade de vida, } \\
\text { procurando tornar os cargos mais produtivos } \\
\text { e satisfatórios. }\end{array}$ & $\begin{array}{l}\text { Valorização dos cargos, mediante } \\
\text { análise de elementos. } \\
\text { organizacionais, ambientais e } \\
\text { comportamentais. }\end{array}$ \\
\hline Nadler e Lawler, 1983 & $\begin{array}{l}\text { Maneira de pensar a respeito das pessoas, } \\
\text { participação na resolução de problemas, } \\
\text { enriquecimento do trabalho, melhoria no } \\
\text { ambiente de trabalho. }\end{array}$ & $\begin{array}{l}\text { Visão humanista no ambiente de } \\
\text { trabalho. }\end{array}$ \\
\hline Neri, A.M , 1992 & $\begin{array}{l}\text { Atendimento das expectativas quanto a se } \\
\text { pensar a respeito de pessoas, trabalho e } \\
\text { organização, de forma simultânea e } \\
\text { abrangente. }\end{array}$ & Visão holística. \\
\hline Lippitt, 1978 & $\begin{array}{l}\text { Oportunidade para o indivíduo satisfazer a } \\
\text { grande variedade de necessidades pessoais. }\end{array}$ & $\begin{array}{l}\text { Trabalho, crescimento pessoal, } \\
\text { tarefas completas, sistemas } \\
\text { abertos. }\end{array}$ \\
\hline Berlanger, 1992 & $\begin{array}{l}\text { Melhorar as condições de trabalho, de modo } \\
\text { a proporcionar aos indivíduos melhores } \\
\text { condições de vida e cargos mais satisfatórios } \\
\text { para a própria pessoa, com reflexos na } \\
\text { produtividade. }\end{array}$ & $\begin{array}{l}\text { Condições de vida e cargos mais } \\
\text { satisfatórios. }\end{array}$ \\
\hline Ginzberg et alii, 1979 & $\begin{array}{l}\text { Experiências de humanização do trabalho sob } \\
\text { dois aspectos: reestruturação do emprego e } \\
\text { grupos semi-autonômos. }\end{array}$ & $\begin{array}{l}\text { Posto individual de trabalho e } \\
\text { processo decisório. }\end{array}$ \\
\hline Bergeron, 1982 & $\begin{array}{l}\text { Aplicação concreta de uma filosofia humanista } \\
\text { pela introdução de métodos participativos. }\end{array}$ & $\begin{array}{l}\text { Mudança e participação } \\
\text { com foco sociotécnico. }\end{array}$ \\
\hline Camacho, 1995 & $\begin{array}{l}\text { Classificação de programas: orientação } \\
\text { familiar, saúde, ambiente, contato e convívio, } \\
\text { evolução/desenvolvimento, cultura e } \\
\text { desligamento. }\end{array}$ & $\begin{array}{l}\text { Foco motivacional: sobrevivência } \\
\text { com dignidade, segurança, } \\
\text { participação, auto-realização e } \\
\text { perspectiva de futuro. }\end{array}$ \\
\hline Dantas, 1996 & $\begin{array}{l}\text { Gerência pela Qualidade Total - GQT: } \\
\text { Utilização de } 5 \text { s, diagrama de causa e efeito e } \\
\text { procedimentos da Qualidade Total nos } \\
\text { programas de saúde. }\end{array}$ & $\begin{array}{l}\text { Foco: promoção da saúde: controle } \\
\text { do colesterol, capacidade física e } \\
\text { aeróbica, doenças coronárias. }\end{array}$ \\
\hline
\end{tabular}

Fonte: Dados de pesquisa, 1996 


\subsubsection{Visão biopsicossocial}

A construção da Qualidade de Vida no Trabalho ocorre a partir do momento em que se olham as pessoas como um todo, o que chamamos de enfoque biopsicossocial.

Esta será a visão adotada para a análise diferencial de Qualidade de Vida no Trabalho. O conceito biopsicossocial origina-se da Medicina Psicossomática, que propõe visão integrada, holística do ser humano, em oposição à abordagem cartesiana, que divide o ser humano em partes.

Toda pessoa é um complexo biopsicossocial, isto é, tem potencialidades biológicas, psicológicas e sociais que respondem simultaneamente às condições de vida. Estas respostas apresentam variadas combinações e intensidades nestes três níveis e podem ser mais visíveis em um deles, embora todos sejam sempre interdependentes.

O nível biológico refere-se às características físicas herdadas ou adquiridas ao nascer e durante toda a vida. Inclui metabolismo, resistências e vulnerabilidades dos órgãos ou sistemas.

O nível psicológico refere-se aos processos afetivos, emocionais e de raciocínio, conscientes ou inconscientes, que formam a personalidade de cada pessoa e o seu modo de perceber e posicionar-se diante das pessoas e das circunstâncias que vivência. 
O nível social revela os valores, as crenças, o papel na família, no trabalho e em todos os grupos e comunidades a que cada pessoa pertence e de que participa. O meio ambiente e a localização geográfica também formam a dimensão social.

Esta conceituação é descrita por Lipowski (1986) como resgate de uma visão mais ampla do conceito de saúde, que tem sido a tendência nas últimas décadas. A saúde não é apenas ausência de doença, mas também o completo bem-estar biológico, psicológico e social. Esta conceituação, adotada pela Organização Mundial de Saúde (OMS), em 1986, foi citada por Dejours (1986) e abre um campo significativo para a compreensão dos fatores psicossociais na vida moderna e, especificamente, na performance e cultura organizacional da saúde do trabalho.

Esta compreensão do ser humano, em que o indivíduo é o seu corpo, revela condições de vida e marcas das experiências vividas e desejadas. Situa-se na mesma proposta conceitual da visão holística de homem. Daí ele ser o eixo conceitual de Qualidade de Vida no Trabalho.

Alvesson (1988:78) cita estudos de Bolinder e Ohlström's, em que se estabelece clara correlação entre experiências de stress mental e pressões no trabalho e sintomas psicossomáticos. As causas observadas destas correlações são trabalhos com exaustivo esforço físico, padrões forçados de trabalho (forced rates of work), problemas salariais, atividades estúpidas e desinteressantes.

A escola sociotécnica cita em seus estudos a introdução de um método de trabalho que, num primeiro momento, não gerou maior produtividade, mas fez com 
que as taxas de absenteísmo e rotatividade se elevassem, juntamente com incidência epidêmica de desordens psicossomáticas entre os mineiros (Biazzi Jr., 1994).

Esses exemplos demonstram, juntamente com o destaque a seguir, a importância da abordagem psicossomática para a compreensão da vida no trabalho.

"O distúrbio psicossomático entendido como mensagem, como comunicação, como linguagem arcaica, não verbal, é um dos meios que o homem tem para comunicar, e a linguagem do corpo, e linguagem do órgão; carregados de significados indiretos, que encontram a sua simplificação na interpretação simbólica, analógica ou metafórica do sintoma. Entender o que quer dizer um determinado sintoma significa aumentar o conhecimento de si mesmo e a consciência do que se é" (Petrone,1994:29).

Associado aos distúrbios psicossomáticos está o stress: estado de tensão do organismo sob situação de pressão imediata ou situação experenciada, que gera diversos estados de ansiedade. Rodrigues A. L. (1992) faz detalhada revisão sobre os aspectos psicossociais do stress, o que leva a concluir que não há Qualidade de Vida no Trabalho, se as condições em que se trabalha não permitem viver em um bom nível de stress, tendo de preferência como meta o eustresse e não o distress, tensão nociva que gera, entre outros motivos, os distúrbios psicossomáticos.

Samulsk et alii (1996:64) propõem a compreensão do fenômeno do stress "como transação que envolve risco, perda ou situação, na qual capacidades a mais devem ser mobilizadas, e quanto maior é o esforço, mais duvidoso se torna o acontecimento". Apresentam-se assim dois componentes básicos para a 
ocorrência de stress: exigências e capacidade. Exigências condicionadas ao meio externo. Exigências internas relacionam-se com metas desejáveis, valores, disposição de avaliação.

O stress é vivido no trabalho a partir da capacidade de adaptação, que envolve sempre o equilíbrio obtido entre exigência e capacidade. Se o equilíbrio for atingido, obtém-se o bem-estar; se for negativo, gerará diferentes graus de incerteza, conflitos e sensação de desamparo.

O stress é, talvez, a melhor medida do estado de bem-estar obtido ou não pela pessoa, isto é, a qualidade de vida no trabalho é individualizada na pessoa por meio de suas diferentes manifestações de stress.

No contexto do trabalho, esta abordagem associa-se à ética da condição humana. Esta ética busca desde a identificação, eliminação, neutralização ou controle dos riscos ocupacionais observáveis no ambiente físico, padrões de relações de trabalho, carga física e mental requerida para cada atividade, implicações políticas e ideológicas, dinâmica da liderança empresarial e do poder formal ou informal até o significado do trabalho em si, relacionamento e satisfação no trabalho (Cerquinho, 1994).

De forma geral, as pesquisas clássicas sobre condição humana no trabalho voltaram-se inicialmente para a questão do moral no grupo a partir da demonstração de que uma fábrica é uma instituição social (Mayo, 1945 in Tragtenberg, 1985:88), para necessidades e suas diversas hierarquias e classes, tais como necessidades básicas de segurança, de associação, de prestígio e autorealização (Maslow, 1965), de motivação com incentivos ou manutenção com 
benefícios que geram estabilidade de interesse e comportamento de continuidade (Herzberg, 1966), estilos de liderança e resultados entre líder, liderados e alvo a ser atingido, maturidade e processos decisoriais (McGregor, 1944, Argyris, 1953, apud Hersey e Blanchard, 1977).

As novas contribuições para o estudo do comportamento organizacional são: as abordagens sistêmicas, a administração participativa, o avanço das pesquisas e o interesse das questões prevencionistas, ergonômicas e da saúde mental do trabalho, os movimentos sociais e a escola francesa, especialmente Dejours (1987, 1994), com enfoque na psicopatologia do trabalho. Sua principal contribuição é a análise do sofrimento mental no trabalho e a utilização de uma metodologia que atua sobre os espaços coletivos de trabalho, de forma a diferenciar e resgatar o sofrimento desagregador e o sofrimento criativo.

\footnotetext{
"A organização do trabalho foi então conceituada pelo contraste com as condições de trabalho, sobre as quais a maioria dos pesquisadores médicos e ergonômicos focalizavam seus estudos. Por condições de trabalho deve-se entender as pressões físicas, mecânicas, químicas e biológicas do posto de trabalho. As pressões de trabalho têm por alvo principal o corpo dos trabalhadores, onde elas podem ocasionar desgaste, envelhecimento e doenças somáticas. (Dejours, Abdoucheli, Jayet, 1994:125).
}

Chanlat e colaboradores (1992) consolidaram processos referentes às dimensões esquecidas na organização, como a inveja, o tempo, a antropologia, a comunicação, o símbolo.

Rodrigues (1994), apesar de não apresentar conceito específico, demonstra que houve evolução no enfoque do ser humano no trabalho; destaca em pesquisa realizada com gerentes os aspectos de participação, poder e autonomia como fatores importantes para qualidade de vida dos executivos pesquisados. 
Do ponto de vista existencial, Crema (1992) aponta para o momento de desafios, de mudanças e da necessidade de inteireza do ser humano, vinculada à dimensão interconectada do saber e do amor, de forma a não se fragmentar diante dos "traumatismos de todos os tempos".

Dejours (1994) refere-se à Qualidade de Vida no Trabalho como condições sociais e psicológicas do trabalho, especificamente no que se refere ao sofrimento criador e ao sofrimento patogênico, este último, "aparece quando todas as margens de liberdade na transformação, gestão e aperfeiçoamento da organização do trabalho já foram utilizadas". O desafio é a transformação do sofrimento em criatividade que beneficie a identidade, a resistência do sujeito ao risco de desestabilização psíquica e somática.

Buscando uma metodologia de abordagem em ambientes organizacionais, Dejours (In Chanlat, 1992) propõe a criação do espaço coletivo, que é o momento em que, em situação de grupo, as pessoas compartilham seus valores e sentimentos sobre questões específicas, inclusive do trabalho.

Valorizando o indicador participação, Werther e Davis (1983:70-87) afirmam ser a QVT um dos grandes desafios da administração e do desenvolvimento de pessoal. Assim descrevem os fatores que afetam a QVT: "supervisão, condições de trabalho, pagamento, benefícios e projeto do cargo... uma boa vida de trabalho significa um cargo interessante, desafiador e compensador".

Segundo Walton (1975), Qualidade de Vida no Trabalho refere-se a "valores ambientais e humanos, negligenciados pelas sociedades industriais em favor do avanço tecnológico, da produtividade e do crescimento econômico". Esse autor 
apresenta pormenorizado histórico da Qualidade de Vida no Trabalho. Nele nos basearemos para a elaboração desta tese.

Especificamente quanto à natureza conceitual da Qualidade de Vida no Trabalho, Nadler e Lawler (In: Rodrigues M.V.C., 1994) propõem fases evolutivas. Os autores concluem com uma visão pessimista do futuro, em que, segundo eles, deverá ocorrer desvalorização do termo em alguns setores - que eles não identificam, em decorrência da globalização, isto é, uso indiscriminado do termo.

Fernandes E.C.(1996, 1992a, b e c, 1990, 1988), apresenta contribuições para a construção e compreensão dos conceitos de Qualidade de Vida no Trabalho. Afirma que a expressão Qualidade de Vida no Trabalho está associada à melhoria das condições físicas, programas de lazer, estilo de vida, instalações, atendimento a reivindicações dos trabalhadores, ampliação do conjunto de benefícios.

Do ponto de vista das relações de trabalho, a pesquisadora comenta que as melhores condições de trabalho advêm de uma evolução da sociedade: "QVT está intimamente ligada à democracia industrial e à humanização do trabalho, cuja corrente mais forte é a francesa, que utiliza como metodologia científica o depoimento sistemático dos empregados sobre suas atividades" (Jornal de Recursos Humanos, 1992).

Além dos autores citados, o tema qualidade de vida no trabalho aparece especialmente em estudos com professores de diversos sistemas organizacionais, servidores públicos e ocupações operárias específicas. Raramente são citados 
estudos realizados em empresas privadas. As dimensões mais analisadas voltamse para o clima organizacional e para a prevenção do stress. 


\subsubsection{Abordagens sobre a Qualidade de Vida no Trabalho}

A Qualidade de Vida no Trabalho pode ser analisada com base em três abordagens:

- Sistemas de qualidade

- Potencial humano

- Saúde e segurança do trabalho

A abordagem de qualidade de vida no trabalho do ponto de vista dos sistemas de qualidade envolve as políticas e os programas de Qualidade Total, Certificação ISO 9000 e muitos outros métodos e práticas gerenciais centrados na satisfação do cliente.

A abordagem sobre o potencial humano refere-se à capacitação, motivação e desenvolvimento profissional da força de trabalho, educação para a convivência social, para a utilização de potencialidades e para o aprendizado organizacional.

A abordagem sobre saúde e segurança refere-se à preservação, prevenção, correção ou reparação de aspectos humanos e ambientais que neutralizam riscos na condição de trabalho.

Os problemas de condições de trabalho têm sido denunciados por cientistas sociais, filósofos, médicos e psicólogos. No capítulo "A face repugnante" de Imagens da Organização, Morgan (1996:279) cita estudos em atividades de manufatura, como panificação, confecção de roupas, fábrica de fósforos, indústria 
cerâmica e conclui que muitos problemas básicos de higiene e segurança ainda persistem, destacando números de acidentes de trabalho, mortes por doenças ocupacionais e que, quando a questão é eficiência versus segurança, sempre vence a primeira: em lugar de ler "segurança em primeiro lugar" leia-se "segurança quando conveniente".

A base econômica dos problemas de higiene e segurança continua presente, semelhante à dos primeiros fabricantes do século XIX, quando faziam com que seus empregados trabalhassem até quase à morte para não incorrerem em perdas por ociosidade das máquinas. É também de considerar que existem empregados que tiram vantagem das regras e de esquemas de indenização. 0 autor citado aborda também os riscos ocupacionais associados às exigências legais.

Mendes (1995:46), em seu compêndio Patologia do trabalho, destaca o Karoshi: "morte súbita que vem ocorrendo no Japão em decorrência de trabalho excessivo e prolongado", como um incidente importante nas relações de trabalho da competição empresarial.

Para Harman e Hormann (1990), as novas atitudes de vida no trabalho são como uma nova forma de ser. Entre vários tipos de movimentos sociais, apresentam o atendimento holístico à saúde. As características deste atendimento holístico são: a auto-responsabilidade pelo bem-estar físico, a prática da medicina preventiva, a presença de um curador interior, a doença como oportunidade para melhorias e uma definição aberta de saúde; ser saudável é estar robusto, pleno de um senso energizado de bem-estar, tranqüilo, vigoroso. Implica estar integrado 
consigo mesmo, em paz com a própria natureza, com os outros e com todo o ambiente.

Hudson (1996) destaca a influência da cultura brasileira nos riscos ocupacionais, exemplificando com o trabalho pesado para os homens, que desdobrou na crença de que quanto mais peso carrega, mais homem é.

Se forem consideradas as propostas de Francesco de Cicco (1996) e Frosini e Carvalho (1995:40-54), estes aspectos vêm sendo documentados na futura ISO 18000, ou atuais BS 8750, Guide to health and safety management, que contém diretrizes específicas. A norma ISO 14000 refere-se à gestão ambiental e objetiva garantir a preservação do ambiente ecológico.

Essas normas tendem a ter grande adesão em função das práticas administrativas e da legislação existentes no país há mais de três décadas. Elas foram aperfeiçoadas em virtude da (OIT), da maior consciência sindical e dos movimentos de preservação da vida na Terra. 


\subsubsection{Contribuição das ciências}

A sociedade vive novos paradigmas sobre modos de vida dentro e fora do trabalho, construindo novos valores relativos às demandas de Qualidade de Vida no Trabalho. Neste contexto, as ciências têm dado contribuições específicas.

Entre as contribuições científicas em vários campos diretamente relacionados com a Qualidade de Vida no Trabalho, destacam-se:

Saúde: nessa área, a ciência tem buscado preservar a integridade física, mental e social e não apenas ausência de doença, com maior expectativa de vida e avanços biomédicos.

Ecologia: vê o homem como parte integrante e responsável pela preservação do ecossistema dos seres vivos e dos insumos da natureza.

Ergonomia: estuda as condições de trabalho ligadas à pessoa. Fundamenta-se na medicina, psicologia, motricidade e tecnologia industrial Gendrier (1988).

Psicologia: juntamente com a filosofia, demonstra a influência das atitudes internas e perspectivas de vida da análise e inserção de cada pessoa em seu trabalho e a importância do significado intrínseco das necessidades individuais. 
Sociologia: resgata a dimensão simbólica do que é compartilhado e construído socialmente, demonstrando as implicações de quem influencia e é influenciado nos diversos contextos culturais e antropológicos.

Economia: enfatiza a consciência social de que os bens são finitos e que a distribuição de bens, recursos e serviços deve envolver a responsabilidade social e a globalização.

Administração: procura aumentar a capacidade de mobilizar recursos, cada vez mais sofisticados e impactantes em termos tecnológicos, diante de objetivos mais específicos, rápidos e mutantes.

Engenharia: pesquisa novas formas de relações de produção voltadas para multicapacitação, flexibilização da manufatura, produção enxuta, defeito zero, armazenamento mínimo de materiais e uso da tecnologia e controle estatístico de processos. 


\subsection{BASES CONCEITUAIS DOS INDICADORES DAS VARIÁVEIS}

"É necessário fazer BEM o bem." Gomez Perez

Indicadores são ferramentas de planejamento e decisão que permitam clareza de critérios, não-ambigüidade de avaliação, facilidades de levantamento, de compreensão e de comparação. Os Indicadores de Desempenho devem captar os efeitos interativos das funções praticadas na organização (Prêmio Nacional da Qualidade, 1994:5).

Os objetivos da construção de indicadores pode estão associados às necessidades políticas decisoriais, à compreensão das características culturais de uma comunidade, a ferramentas de desenvolvimento e à competitividade internacional.

Outros critérios utilizados para a seleção dos indicadores são crenças pessoais, qualidade pessoal da vida, qualidade das relações sociais, qualidade da vizinhança, padrão internacional da qualidade de vida (NET - 18/12/95: Best ways of measuring quality of life).

É difícil especificar as definições operacionais que constituirão o indicador representativo de determinado setor (UNCTAD, 1991, in Brisolla, 1995:13). 
Coutinho, Ferraz e colaboradores (1994: anexo I) apresentam indicadores empresariais relativos ao capital humano na empresa para o cálculo da competitividade no Brasil.

Foi feita uma consolidação dos indicadores no Quadro 1.2, indicados pelos autores no Sistema de Indicadores de Competitividade, com o objetivo de destacar os sinalizadores específicos de Recursos humanos, que são interessantes para a composição dos critérios de Qualidade de Vida no Trabalho. Destaca-se que na proposição conceitual de competitividade, Coutinho e Ferraz (1994:95) defendem que "a construção da competitividade não pode prescindir de fundamentos sociais, educação básica universalizada, elevada qualificação da força de trabalho, novas formas de organização do processo de produção, relações de trabalho, cooperativas e mercados que exigem qualidade".

Quadro 1.2 Indicadores empresariais associados a recursos humanos.

\begin{tabular}{|c|c|c|}
\hline Foco & Indicador & Fonte \\
\hline \multirow[t]{3}{*}{ Custos } & $\begin{array}{l}\text { - Evolução dos custos de mão-de-obra e } \\
\text { principais insumos }\end{array}$ & IBGE \\
\hline & $\begin{array}{l}\text { - Evolução da remuneração média do trabalho } \\
\text { por hora }\end{array}$ & IBGE \\
\hline & $\begin{array}{l}\text { - Carga tributária: contribuições sociais/valor da } \\
\text { produção }\end{array}$ & IBGE \\
\hline \multirow[t]{2}{*}{ Produtividade } & $\begin{array}{l}\text { - Número de horas trabalhadas: produto } \mathrm{x} \\
\text { pessoal }\end{array}$ & IBGE \\
\hline & $\begin{array}{l}\text { - Número de horas trabalhadas } x \text { máquinas e } \\
\text { ferramentas }\end{array}$ & IBGE \\
\hline \multirow[t]{3}{*}{$\begin{array}{l}\text { Qualidade e meio } \\
\text { ambiente }\end{array}$} & $\begin{array}{l}\text { - Normas técnicas nacionais e internacionais } \\
\text { cumpridas em relação a qualidade }\end{array}$ & $\begin{array}{l}\text { entidade empresarial e } \\
\text { Inmetro }\end{array}$ \\
\hline & - Idem com relação ao controle ambiental & $\begin{array}{l}\text { entidade empresarial e } \\
\text { IBAMA }\end{array}$ \\
\hline & - Índices de perda e retrabalho & entidade empresarial \\
\hline
\end{tabular}


Foco

Indicador

Fonte

\begin{tabular}{|c|c|c|}
\hline Produtividade & - Número de horas trabalhadas & entidade empresarial \\
\hline & $\begin{array}{l}\text { - Produto em valor / pessoal ocupado na } \\
\text { produção }\end{array}$ & entidade empresarial \\
\hline $\begin{array}{l}\text { Econômico } \\
\text { financeiro }\end{array}$ & $\begin{array}{l}\text { - Rentabilidade, grau de endividamento, grau } \\
\text { de liquidez }\end{array}$ & entidade empresarial \\
\hline \multirow[t]{3}{*}{$\begin{array}{l}\text { Educação } \\
\text { Tecnologia }\end{array}$} & - Gastos em educação/ PIB & $\begin{array}{l}\text { Ministério da } \\
\text { Educação e IBGE }\end{array}$ \\
\hline & $\begin{array}{l}\text { - Taxa de escolaridade: população matriculada } \\
\text { x população em idade escolar }\end{array}$ & $\begin{array}{l}\text { Ministério da } \\
\text { Educação e IBGE }\end{array}$ \\
\hline & - Pessoal ocupado em P \& D & $\begin{array}{l}\text { Secretaria de Ciência } \\
\text { e Tecnologia e } \\
\text { IBGE/entidade } \\
\text { empresarial }\end{array}$ \\
\hline \multirow[t]{6}{*}{$\begin{array}{l}\text { Educação e } \\
\text { tecnologia }\end{array}$} & $\begin{array}{l}\text { - Gastos em treinamento de recursos humanos/ } \\
\text { valor da produção }\end{array}$ & $\begin{array}{l}\text { IBGE/entidade } \\
\text { empresarial }\end{array}$ \\
\hline & $\begin{array}{l}\text { - Número de empregados em treinamento } \mathrm{x} \\
\text { empregados totais }\end{array}$ & $\begin{array}{l}\text { IBGE/entidade } \\
\text { empresarial }\end{array}$ \\
\hline & $\begin{array}{l}\text { - Composição da escolaridade de recursos } \\
\text { humanos }\end{array}$ & $\begin{array}{l}\text { IBGE/entidade } \\
\text { empresarial }\end{array}$ \\
\hline & $\begin{array}{l}\text { - Grau de difusão das tecnologias de } \\
\text { manufaturas avançadas }\end{array}$ & entidade empresarial \\
\hline & $\begin{array}{l}\text { - Idade tecnológica dos equipamentos } \\
\text { produtivos }\end{array}$ & entidade empresarial \\
\hline & $\begin{array}{l}\text { - Gastos com insumos de modernização } \\
\text { tecnológica }\end{array}$ & entidade empresarial \\
\hline $\begin{array}{l}\text { Investimento em } \\
\text { capacidade } \\
\text { produtiva }\end{array}$ & - Parque instalado, investimento $x$ faturamento & entidade empresarial \\
\hline
\end{tabular}

Fonte: Adaptação de Coutinho, Ferraz e colaboradores (1994: anexo I).

Outro importante critério de seleção são os indicadores microeconômicos do desempenho competitivo. Bonelli, Fleury e Fritsh (1993) destacam que as análises tradicionais do desempenho industrial têm privilegiado as variáveis relacionadas ao custo de operação das empresas, geralmente expressas em termos físicos. Os indicadores anteriores eram baseados em conceitos e magnitudes contábeis. Têm sido insatisfatórios em função das novas características tecnológicas e organizacionais. 
Os indicadores de produtividade, isto é, a relação entre produto(s) e insumo (s) necessários, têm tido contribuições de muitos estudiosos. Bonelli, Fleury Fritsh (1993:14-19), destacam os seguintes:

- Porter (1980): variáveis de competitividade custos e diferenciação

- Kaplan (1990): medidas operacionais: entrega, confiabilidade, qualidade e recursos humanos.

- Bonelli, Fleury e Fritsh (1993): dimensões de desempenho em manufaturas; custos, qualidade, tempo, inovatividade e flexibilidade.

- Stalk (1988): confiabilidade e prazo de entrega.

Para indicadores de serviços, foi selecionada a contribuição de Yoshinaga (IMAN, s/d): Educação, transporte, saneamento, energia, comunicações, tecnologia, construção civil, gestão econômico-empresarial, judiciário, legislativo, relações capital-trabalho.

Indicadores Empresariais de Capacitação Tecnológica (ANPEI 1994, ano 3) que têm sido utilizados são: número de empregados, faturamento bruto, lucro líquido, investimento de capital, índice total de defeitos, participação do mercado nacional. 


\subsubsection{Construção dos indicadores}

Os indicadores de qualidade de vida no trabalho têm como base o Índice de Desenvolvimento Social (IDS), o Índice de Desenvolvimento Humano (IDH) (Rodrigues, 1991) e as categorias de Walton (1975).

É uma tentativa de cobrir de forma mais abrangente as diversas dimensões da qualidade de vida do trabalho, tanto do ponto de vista da empresa, como do ponto de vista do empregado.

Desenvolvimento humano é um processo para ampliação da gama de opções e oportunidades das pessoas e deve incorporar as dimensões em que se manifestam essas opções: econômica, social, política, cultural e ambiental.

É uma medida socioeconômica que complementa os dados do PIB e é um índice de natureza basicamente estrutural. $O$ conceito de índice de desenvolvimento humano - IDH e sua divulgação no Brasil, através do PNUD, teve início em 1990. Os indicadores estão associados ao ciclo social de conferências da Organização das Nações Unidas (ONU) e refere-se à natureza e sentido do desenvolvimento, mais especificamente à realização (ou satisfação) pessoal dos indivíduos de um país ou região.

O Relatório de Desenvolvimento Humano do Brasil (1996:4) enfatiza três opções básicas do desenvolvimento humano: desfrutar uma vida longa e saudável, adquirir conhecimento e ter acesso aos recursos necessários para o 
padrão de vida decente. Tais opções são incorporadas ao índice através de variáveis que medem longevidade, nível educacional e renda.

Sobre renda familiar e problemas socioeconômicos brasileiros, Rodrigues, M.C.P (1994) estimou que existam em torno de $28 \%$ de famílias, referindo-se a famílias cuja renda esteja em torno de um salário mínimo per capita.

A composição do Índice de Desenvolvimento Social - IDS é esperança de vida, grau de alfabetização, distribuição de renda. A composição do Índice de Desenvolvimento Humano - IDH é: alimentação, saúde, seguro de vida, conhecimento, condições de trabalho, segurança contra o crime, lazer, participação econômica, participação cultural e política.

Alguns autores têm apresentado estudo com novos critérios de indicadores. No Brasil, Fernandes, E.C. (1992:7) aponta os seguintes focos dos programas de Qualidade de Vida no Trabalho - QVT: reestruturação dos postos de trabalho, melhoria da cultura organizacional, criação de grupos autônomos ou autogerenciados.

O conjunto mais completo de critérios e indicadores de qualidade de vida no trabalho foi proposto por Walton (1975). O autor coloca a necessidade de padrões objetivos e subjetivos de compensação. Sinaliza aspectos da saúde física e mental, integração social, desenvolvimento comunitário e contribuição das teorias de desenvolvimento humano, citando a teoria de Hierarquia de Necessidades de Maslow. Diferencia situações potenciais de operacionalizações corretas para os padrões e critérios utilizados. Por fim, relaciona as seguintes fases de evolução da Qualidade de Vida (1975: 92-93): 
- 1930 -1940: ênfase na segurança do trabalho;

- 1950: relações positivas entre moral e produtividade;

- 1960: iguais oportunidades de trabalho e enriquecimento de tarefas;

- 1970: valores afetivos, necessidade e aspirações humanas, responsabilidade social.

Nesta visão evolutiva, Walton propôs há duas décadas oito critérios que transcrevemos no Quadro 1.3.

Quadro 1. 3 Critérios de Walton para Qualidade de Vida no Trabalho.

\begin{tabular}{|c|c|c|}
\hline Critério & Indicadores & Descrição \\
\hline $\begin{array}{l}\text { Compensação justa e } \\
\text { adequada }\end{array}$ & $\begin{array}{l}\text { Salário } \\
\text { Jornada de trabalho }\end{array}$ & $\begin{array}{l}\text { - } \text { Referente também à } \\
\text { remuneração } \\
\text { - } \quad \text { Carga horária de trabalho }\end{array}$ \\
\hline Condições de trabalho & $\begin{array}{l}\text { Ambiente físico } \\
\text { Salubridade }\end{array}$ & $\begin{array}{l}\text { - No sentido de conforto } \\
\text { ergonômico } \\
\text { - Ausência de exposição a riscos } \\
\text { ocupacionais }\end{array}$ \\
\hline $\begin{array}{l}\text { Uso e desenvolvimento das } \\
\text { capacidades pessoais }\end{array}$ & $\begin{array}{l}\text { Autonomia } \\
\text { Estima } \\
\text { Capacitação múltipla } \\
\text { Informações sobre o trabalho }\end{array}$ & $\begin{array}{l}\text { - Liberdade para tomar decisões } \\
\text { - O quanto se sente querido por } \\
\text { parte dos colegas } \\
\text { - Qualificação específica e geral } \\
\text { para o exercício da função } \\
\text { - De que forma e em que } \\
\text { profundidade se é informado } \\
\text { sobre o trabalho }\end{array}$ \\
\hline $\begin{array}{l}\text { Oportunidade de } \\
\text { crescimento e segurança }\end{array}$ & $\begin{array}{l}\text { Carreira } \\
\text { Desenvolvimento pessoal } \\
\text { Estabilidade no emprego }\end{array}$ & $\begin{array}{l}\text { - } \text { Movimento de ascensão } \\
\text { profissional } \\
\text { - Melhoria em performance } \\
\text { - Risco de demissão } \\
\end{array}$ \\
\hline $\begin{array}{l}\text { Integração social na } \\
\text { organização }\end{array}$ & $\begin{array}{l}\text { Ausência de preconceitos } \\
\text { Habilidade social } \\
\text { Valores Comunitários }\end{array}$ & $\begin{array}{l}\text { - Inclusão ou exclusão na } \\
\text { empresa } \\
\text { - Educação e diplomacia } \\
\text { - Valorização das tarefas pela } \\
\text { empresa }\end{array}$ \\
\hline (continuação) & $\begin{array}{l}\text { Direitos garantidos } \\
\text { Privacidade } \\
\text { Imparcialidade }\end{array}$ & $\begin{array}{l}\text { - Pagamentos, férias, seguros etc } \\
\text { - Não invasão na documentação } \\
\text { e decisões } \\
\text { - Ausência de subjetividade e } \\
\text { decisões objetivas }\end{array}$ \\
\hline Critério & Indicadores & Descrição \\
\hline
\end{tabular}




\begin{tabular}{|c|c|c|}
\hline $\begin{array}{l}\text { Trabalho e espaço total de } \\
\text { vida }\end{array}$ & $\begin{array}{l}\text { Liberdade de expressão } \\
\text { Vida pessoal preservada } \\
\text { Horários previsíveis }\end{array}$ & $\begin{array}{l}\text { - Revelação das opiniões } \\
\text { - Ausência de interferência na } \\
\text { vida pessoal } \\
\text { - Uso do tempo pessoal- } \\
\text { profissional }\end{array}$ \\
\hline $\begin{array}{l}\text { Relevância social do } \\
\text { trabalho }\end{array}$ & $\begin{array}{l}\text { Imagem da empresa } \\
\text { Responsabilidade social da } \\
\text { empresa }\end{array}$ & $\begin{array}{l}\text { - } \begin{array}{l}\text { Credibilidade da empresa na } \\
\text { comunidade }\end{array} \\
\text { - Preservação ambiental, geração } \\
\text { de empregos, metaqualidade }\end{array}$ \\
\hline
\end{tabular}

Fonte: Adaptado de WALTON, R. Criteria for quality life. In: DAVIS, L.E., CHERNS, A.B. The quality of working life: problems, prospects and state of the art. New York: The Free Press, 1975: v. 1, p. 43-97.

Levering (1995:18) cita os estudos de Arthur D. Little, publicados originalmente em 1993, sobre as companhias com bom ambiente de trabalho e que tendem a ter melhor desempenho financeiro. No Quadro 1.4 publicado no artigo, foram utilizados todos os indicadores para a construção do questionário de coleta de dados.

Quadro 1.4 Motivadores-chave de um excelente lugar para se trabalhar.

\begin{tabular}{lll}
\hline \multicolumn{1}{c}{ Motivador } & Dimensões & \multicolumn{1}{c}{ Descrição } \\
\hline Confiança & Credibilidade & $\begin{array}{l}\text { Qualidade que a direção da empresa tem junto ao } \\
\text { empregados, que passam a acreditar nela e a contar com } \\
\text { ela }\end{array}$ \\
\hline "Jogo limpo" & Regras justas nas relações com os empregados \\
\hline Respeito & $\begin{array}{l}\text { Atitudes básicas que os empregados vêem expressas nas } \\
\text { ações da empresa com relação a eles }\end{array}$ \\
\hline Orgulho & $\begin{array}{l}\text { Sentimento que os empregados têm em relação ao seu } \\
\text { trabalho e a empresa }\end{array}$ \\
\hline Camaradagem & Qualidade das interações no ambiente de trabalho \\
\hline Fonte: Levering (1995:18). & \\
Levering aponta os tipos de relacionamento no trabalho com base nesses
\end{tabular}


que têm orgulho do trabalho e empregados que se relacionam com camaradagem com outros empregados.

A Escala de Valores Organizacionais (Tamayo e Gondim, 1996:66) traz um levantamento com 537 empregados de 16 empresas públicas e privadas, na qual foram encontrados cinco fatores:

- fator 1: eficiência e qualidade do produto;

- fator 2: relações interpessoais na organização;

- fator 3: estilo de gestão;

- fator 4: desenvolvimento técnico.

- fator 5: respeito ao empregado.

As Normas Regulamentadoras da Legislação de Saúde e Segurança foram consolidadas em 1978 (Weber ,1996:15). São indicadores de qualidade de vida, uma vez que determinam programas de eliminação, controle e preservação da saúde e conseqüente bem-estar do ambiente de trabalho.

Entre as normas, alguns programas constam como obrigatórios, como: Comissão Interna de Prevenção de Acidentes (CIPA), Semana Interna de Prevenção de Acidentes (SIPAT), Programa de Prevenção de Riscos Ambientais (PPRA), Controle Médico e de Saúde Ocupacional (PCSMO).

Estes programas viabilizam a gestão da qualidade de vida, uma vez que têm caráter de preservação e controle de riscos das condições de trabalho e conseqüente bem-estar. Têm obrigatoriedade legal de realização e estão ligados à também obrigatória estrutura de profissionais e documentação específica (Manuais de Legislação Atlas, 1996, v.16). 
Entre outras responsabilidades, a gestão de recursos humanos tem grande demanda em salários, carreiras e diagnóstico do clima organizacional. O grau de organização da empresa para atender estas necessidades podem ser bons indicadores de gestão da qualidade de vida no trabalho.

Os salários têm evoluído para um conceito mais amplo e com menores encargos tributários que é a remuneração. Benefícios também estão incorporados neste novo critério de retorno da empresa sobre o desempenho do empregado.

As novas tendências do conceito de remuneração e benefícios têm impulsionadores relativos a pressões externas e pressões internas. Wood Jr. (In Coopers \& Lybrand, 1996:31) considera pressões externas competição, política industrial, importação e exportação, exigências do consumidor, exigências da comunidade, expectativas dos acionistas; e pressões internas conflitos de poder, demanda por maior autonomia no trabalho, demanda por atividades mais criativas e motivadoras, tecnologia da informação, melhoria da formação geral dos empregados.

Em outro aspecto analisado, Dutra (1996:16-19) definiu carreira como mobilidade ocupacional ou profissão: "Caminho estruturado e organizado no tempo e no espaço, fruto da relação estabelecida entre a pessoa e a empresa, englobando as perspectivas de ambas". Envolve o futuro profissional e a necessidade da empresa de envolver empregados. No Brasil, não há dados relevantes acerca do mercado, mas apenas alguns estudos de caso de empresas vanguardistas que buscam gestão compartilhada de carreira. Dutra (1996a) e outros especialistas afirmam que o emprego fixo acabou e o que importa 
atualmente é a empregabilidade. Tem-se, assim, um importante desdobramento deste indicador.

Outros aspectos da administração de recursos indicadores de Qualidade de Vida são política interna e competição, (Senge, 1995): são fatos habituais na vida de quase todas as grandes organizações, nas áreas de negócios, saúde, educação e no governo. São uma função da nossa cultura, que freqüentemente valoriza mais a competição que a colaboração e vê a competitividade entre indivíduos como vital para a inovação. Isso não é bom nem ruim, mas pode criar limitações. A essência do desenvolvimento de novas capacidades de aprendizado é a necessidade de equipes, grupos de pessoas que precisam umas das outras para agir e para coletivamente melhorar suas capacidades.

- Cultura: atividades de lazer, arte e informação cultural que as empresas desenvolvem e que interferem positivamente no clima organizacional e na motivação dos empregados.

- Gentileza: gentileza no trabalho casal (Meladee \& Hanoch McCarty, 1994). Para os autores, a gentileza se traduz em atos de reconhecimento e valorização do outro.

- Educação: a excelência da educação só poderá ser expressa mediante a formação mais ampla do homem, que foi o agente de transformação da sociedade em geral e da indústria em particular (Senai, 1992).

- Produtos ecologicamente corretos (Otto: 1993): os consumidores estão se preocupando mais e mais com o meio ambiente. No futuro não poderemos ter produtos agressivos ao meio ambiente. Para tanto, são necessárias algumas providências, como utilizar embalagens de material reciclado, implantar sistema 
para coleta da água da chuva, reduzir consumo de energia, utilizar transporte de massa, em lugar de carro próprio, não utilizar cloro para alvejar papel, separar o lixo (vidros, papel, plástico) para posterior reciclagem, restrição de produtos com alto teor de chumbo. Na Alemanha esta preocupação é mais importante do que o desemprego. 
A Qualidade de Vida no Trabalho representa hoje a necessidade de atuar mais profundamente na valorização das condições de trabalho, no que se refere aos procedimentos da tarefa em si, ao ambiente físico e aos padrões de relacionamento. Novos processos organizacionais demandam pessoas inovadoras, prontas para superar desafios, participativas, inovadoras e coresponsáveis.

A mudança da natureza no trabalho tem sido grande problema para respostas efetivas de gestão da qualidade de vida. Antes era mais visível o risco ocupacional. Hoje, o risco é mais mental e afetivo e as ferramentas de análise devem ser simbólicas e dedutivas.

Retornando na história das características da qualidade de vida, há o estudo de Rodrigues (1994:26-27) com dados de pesquisa de trabalhadores de 200 anos atrás. Naquela época, condições de trabalho eram caracterizadas por jornada de até 18 horas, salário para garantir apenas a sobrevivência, aversão como sentimento básico ao trabalho, fome como propulsora da atividade laborativa. Outra citação do mesmo autor refere-se a Owen, no final do século XIX, que teria sido um dos primeiros donos de fábrica a proporcionar condições decentes de trabalho. Os salários eram suportáveis e havia educação formal para os operários e seus filhos. 
Após dois séculos, trabalha-se em torno de 40 horas semanais, existe empresas remuneração baseadas no resultado financeiro da empresa, as ferramentas de avaliação de desempenho estão sendo repensadas estrategicamente. A ênfase está na satisfação, compromisso e empregabilidade, busca e prazer com e por meio do trabalho.

Novas respostas são necessárias, como a compreensão das relações trabalho- saúde e como estas relações refletem na qualidade pessoal; mudança de processos e condições ergonômicas visando à humanização do trabalho; atuação em equipes multidisciplinares que dêem suporte às demandas de estilo de vida, ambiente físico e gestão da saúde. Além disso é indispensável propiciar a participação dos empregados nas sugestões e implantação de melhorias.

Do ponto de vista das novas exigências da sociedade, é marcante o número de questões legais, como Normas Regulamentadoras de Controle dos Riscos Ocupacionais, o Serviço Especializado de Segurança e Medicina do Trabalho - SESMT, Programa de Controle Médico e Saúde Ocupacional PCSMO, Programa de Prevenção de Riscos Ambientais. Todas visam à proteção da saúde de trabalhador e especialmente à eliminação de riscos, que geram alto número de acidentes de trabalho e mortes no mundo inteiro. O Brasil é um dos países em que mais ocorrem acidentes de trabalho.

Considerando-se qualidade de vida como ausência de acidentes, sabe-se que a maioria das demandas de Qualidade de Vida originam-se da relação da pessoa com seu trabalho. Algumas delas surgem de forma diretamente ligada à 
tarefa, outras são desencadeadas por condições geradas no trabalho, como mostra o Quadro 1.5.

Quadro 1.5 Classificação das doenças segundo sua relação com o trabalho.

\begin{tabular}{|c|c|}
\hline CATEGORIA & EXEMPLO \\
\hline I. Trabalho como causa necessária & $\begin{array}{l}\text { Intoxicação por chumbo } \\
\text { Silicose }\end{array}$ \\
\hline II. Trabalho como fator contributivo, mas não necessário & $\begin{array}{l}\text { Doença coronariana } \\
\text { Varizes dos membros inferiores } \\
\text { Doenças do aparelho locomotor }\end{array}$ \\
\hline $\begin{array}{l}\text { III. Trabalho como provocador de distúrbio latente, ou } \\
\text { agravador de doença já estabelecida }\end{array}$ & $\begin{array}{l}\text { Bronquite crônica } \\
\text { Úlcera péptica } \\
\text { Eczema } \\
\text { Doenças mentais }\end{array}$ \\
\hline
\end{tabular}

Fonte: Extraído do artigo de René Mendes $A$ promoção da saúde nas empresas: o futuro da medicina do trabalho, já existente", 1996.

Embora haja sinais importantes de evolução nas condições de trabalho, as características e os desafios têm-se renovado. O cenário é de mudanças contínuas, acúmulo de trabalho, horas extras, dificuldades de aprendizado com a tecnologia. Esses fatores concorrem para potencializar problemas de saúde físicos e mentais, gerar sobrecarga emocional, exigir muito mais do relacionamento interpessoal dentro das organizações. Há também ênfase excessiva nas decisões focadas no cliente, o que gera prazos ingênuos, decisões impopulares, disfunções na saúde mental. Black (1995) afirma que está ocorrendo intensificação do trabalho. Para ele, o mal dos anos 70 era o excesso de pessoal; nos anos 90, o mal é a sobrecarga de trabalho decorrente do excesso de pressões externas, desigualdades salariais e medo de desemprego. Cooper (1995) afirma que esta é a década do presenteísmo em oposição ao absenteísmo. As pessoas mais auto-exigentes em relação ao trabalho tendem a sofrer mais. 
1.2.3 Qualidade de Vida no Trabalho no Brasil 
Investigando ações e programas de gestão de recursos humanos, constatase que muitas empresas brasileiras estão buscando novos paradigmas, segundo os quais o potencial humano passa a ser fator real de competência, e os cuidados com relação à humanização ocorrem no posto de trabalho, na qualificação e em situações extensivas à vida pessoal e familiar.

No entanto, a realização desses programas e ações de Qualidade de Vida no Trabalho ainda é pouco explícita como prática associada à competitividade. A maioria tem origem nas atividades de Segurança e Saúde no Trabalho. Estes não se associam à melhoria do clima organizacional e aos programas de qualidade total. Podem-se encontrar iniciativas em empresas de diversos portes e culturas; sem muita dificuldade, descobrem-se planos que "não vingam" pela falta de posicionamento estratégico deles. Existe receptividade dos empregados para programas de Qualidade de Vida. A dificuldade é a demanda estratégica e o status financeiro em relação a outros programas. Programas de Qualidade de Vida no Trabalho surgem mais como gastos do que como investimento.

Não obstante façam parte de qualquer tarefa ou ação gerencial, os problemas de saúde, freqüentemente, representam apenas um ponto secundário, especialmente quando fundamentados em valores culturais questionáveis sobre o que é "sadio" no trabalho. Por exemplo: trabalhar sempre, sem parar, representa força, dedicação e eficiência. O desgaste decorrente deste esforço é considerado como perda necessária para obter-se bons resultados de produtividade. 
Do ponto de vista socioeconômico, a gestão da qualidade de vida tem grandes encargos. No Brasil, existem contrastes sociais que acentuam o grau de responsabilidade social das empresas e que requerem revisão das políticas e práticas de qualidade de vida ligadas desde alimentação até programas extensivos a filhos e cônjuges. Associadas às grandes diferenças sociais, existem características específicas, como o nível salarial do operário que concorre seriamente para os problemas socioeconômicos de condições de trabalho. Segundo o Anuário do IBGE (1993), há "deterioração da qualidade de vida", pois no Brasil $52 \%$ dos trabalhadores ganham até dois salários mínimos. Portanto, remuneração é um problema importante de Qualidade de Vida no Trabalho. Com relação a esse indicador, há duas tendências de gestão de recursos humanos: uma que acredita que Qualidade de Vida no Trabalho - QVT pode ser tudo, menos alterar padrões salariais. Existem dificuldades estruturais e distâncias sociais reproduzidas nos desenhos de cargos e remuneração. Outra vertente visa rever os padrões de remuneração, associando-os a resultados de produtividade da empresa.

De Marchi (1995) afirma que algumas empresas estão transferindo a responsabilidade pela performance de seu pessoal para o departamento médico da empresa. Com o enfoque preventivo, estão implantando centros de condicionamento físico. A criação desses centros e de outras atividades de apoio biopsicossocial demonstra que esses momentos dentro da empresa melhoram o clima organizacional: "as pessoas ficam relaxadas e produzem melhor". Os investimentos em promoção da saúde têm demonstrado ótimos retornos 
econômicos. Por exemplo, os sedentários causam às empresas $36 \%$ mais despesas médicas e, quando têm, precisam ser internados, seu período de recuperação é $54 \%$ mais longo do que os esportistas. Esses dados apontam para a possibilidade de se obterem lucros reais ao investir em qualidade de vida no trabalho.

Para situar as demandas de Qualidade de Vida nas empresas brasileiras, foram selecionadas ações, programas e projetos que identificados entre os anos de 1992-1996. Esses dados, apresentados no Quadro 1.6, demonstram enfoques diversificados, mas com ênfase em promoção da saúde.

Quadro 1.6 Ações e programas de Qualidade de Vida no Trabalho nas empresas brasileiras.

\begin{tabular}{|c|c|c|c|}
\hline Empresas & Atividades & Foco & Fonte \\
\hline Banco de Boston & $\begin{array}{l}\text { Ações de QVT promovidas pela } \\
\text { associação de funcionários com } \\
\text { apoio de RH: estilo de vida, mini } \\
\text { check-up, relaxamento, teatro, } \\
\text { passeio ciclístico }\end{array}$ & $\begin{array}{l}\text { Lazer, realização no } \\
\text { trabalho, saúde e } \\
\text { segurança }\end{array}$ & $\begin{array}{l}\text { Messohn, M.M. , Silva, M.P., jun. } \\
1994 .\end{array}$ \\
\hline $\begin{array}{l}\text { Banco do Brasil, } \\
\text { Banerj, Multibrás, } \\
\text { Goodyear, } \\
\text { Mercedes Benz, }\end{array}$ & $\begin{array}{l}\text { Programas de assistência e } \\
\text { conscientização contra a AIDS. }\end{array}$ & $\begin{array}{l}\text { Atendimento clínico e } \\
\text { educação para saúde }\end{array}$ & $\begin{array}{l}\text { Revista Isto é. Patrão eu tenho AIDS, } \\
(1994: 104-105) .\end{array}$ \\
\hline $\begin{array}{l}\text { Ciba-Geigy } \\
\text { Química }\end{array}$ & $\begin{array}{l}\text { Atividades diversas em prevenção } \\
\text { de acidentes em parceria com o } \\
\text { departamento médico }\end{array}$ & Saúde e seg & $\begin{array}{l}\text { Corrêa, G. De M. , Silveira, A. L. F., } \\
\text { jun.1994. }\end{array}$ \\
\hline $\begin{array}{l}\text { Cindumel - Cia Ind. } \\
\text { de Metais } \\
\text { Laminados }\end{array}$ & $\begin{array}{l}\text { Limpeza da empresa, visando à } \\
\text { integração dos funcionários }\end{array}$ & $\begin{array}{l}\text { Higiene e integração no } \\
\text { Programa de Qualidade } \\
\text { Total }\end{array}$ & $\begin{array}{l}\text { Nomura, P. M., Zacharauskas, I., jun. } \\
1994 .\end{array}$ \\
\hline Copesul & $\begin{array}{l}\text { Parte do Programa de Qualidade } \\
\text { e Produtividade e ações no } \\
\text { ambiente particular e familiar }\end{array}$ & $\begin{array}{l}\text { Qualidade de Vida no } \\
\text { Trabalho e na Vida de } \\
\text { forma ampla }\end{array}$ & $\begin{array}{l}\text { Jornal de Recursos Humanos, 1992, } \\
\text { p. } 6 .\end{array}$ \\
\hline Copesp & $\begin{array}{l}\text { Levantamento e diagnóstico } \\
\text { através de questionário específico }\end{array}$ & \multicolumn{2}{|c|}{ Satisfação dos funcionários Pires, P.P.P., jun. 1994.} \\
\hline (continuação) & $\begin{array}{l}\text { Pesquisa sobre clima } \\
\text { organizacional, que envolveu } \\
\text { condições de trabalho }\end{array}$ & \multicolumn{2}{|c|}{$\begin{array}{l}\text { Satisfação dos funcionários Costa, A.C. , Figueiredo, B., jun. } \\
1994 .\end{array}$} \\
\hline Dow-Química & $\begin{array}{l}\text { Saúde \& Qualidade de Vida: } \\
\text { alimentação, antifumo, ginástica, } \\
\text { patrocínio educacional, }\end{array}$ & $\begin{array}{l}\text { Saúde, treinamento e } \\
\text { desenvolvimento de } \\
\text { pessoal, ética }\end{array}$ & $\begin{array}{l}\text { Relatório específico da empresa, fev., } \\
1996 .\end{array}$ \\
\hline Du Pont & Comitê de Segurança & $\begin{array}{l}\text { Segurança e Proteção } \\
\text { Ambiental }\end{array}$ & $\begin{array}{l}\text { To, R. K., Nishiwaki, M.K., Jun. } 1994 . \\
\text { Informe Du Pont, 26.05.94, }\end{array}$ \\
\hline
\end{tabular}




\begin{tabular}{|c|c|c|c|}
\hline Fast-Food & $\begin{array}{l}\text { Estudo sobre a percepção de } \\
\text { Qualidade de Vida, do ponto de } \\
\text { vista dos funcionários e gerentes } \\
\end{array}$ & $\begin{array}{l}\text { Problemas de QVT no } \\
\text { ambiente de Qualidade } \\
\text { Total em Serviços } \\
\end{array}$ & Moraes, M., 1994. \\
\hline Fundação Cesp & Treinamento de especialistas & $\begin{array}{l}\text { Conceitos e planos de } \\
\text { ação em Qualidade de } \\
\text { Vida no Trabalho - QVT }\end{array}$ & Atividade de Campo,1994. \\
\hline IBM & $\begin{array}{l}\text { Projeto IBM \& Gente } \\
\text { (ver quadro específico, nos } \\
\text { anexos), Política de Porta Aberta }\end{array}$ & $\begin{array}{l}\text { Atividades assistenciais, } \\
\text { saúde e segurança, } \\
\text { organização de RH, } \\
\text { satisfação com a empresa }\end{array}$ & $\begin{array}{l}\text { Texto Interno: IBM \& Gente, 1995, } \\
\text { Fernandes, 1988:7. }\end{array}$ \\
\hline Impressoras Rima & $\begin{array}{l}\text { Campanha de saúde e qualidade } \\
\text { de vida }\end{array}$ & Stress e qualidade de vida & Atividade de campo, 1993 \\
\hline Ishikawajima & $\begin{array}{l}\text { Qualidade de vida dentro e fora } \\
\text { do ambiente de trabalho }\end{array}$ & Promoção da saúde & $\begin{array}{l}\text { Revista Exame. É melhor prevenir do } \\
\text { que remediar, 1992:44-45. }\end{array}$ \\
\hline $\begin{array}{l}\text { Kodak - São José } \\
\text { Dos Campos }\end{array}$ & $\begin{array}{l}\text { Programa para gestantes Kanban } \\
\text { - saúde }\end{array}$ & $\begin{array}{l}\text { Atendimento materno- } \\
\text { infantil }\end{array}$ & $\begin{array}{l}\text { Revista Exame. É melhor prevenir do } \\
\text { que remediar, 1992:44-45. }\end{array}$ \\
\hline $\begin{array}{l}\text { Metal leve, } \\
\text { Pernambucanas, } \\
\text { Freudemberg, ICI, } \\
\text { Copagaz }\end{array}$ & Atendimento psicológico & Assistência psicológica & $\begin{array}{l}\text { Revista Exame, Operários à beira de } \\
\text { uma ataque de nervos, 1991:72-75. }\end{array}$ \\
\hline $\begin{array}{l}\text { METRÔ - São } \\
\text { Paulo }\end{array}$ & $\begin{array}{l}\text { Pesquisa e Sipat -Levantamento e } \\
\text { Apresentação de Dados }\end{array}$ & $\begin{array}{l}\text { Indicadores QVT através } \\
\text { da satisfação individual }\end{array}$ & Atividade de Campo, 1995 \\
\hline Empresas & Atividades & Foco & Fonte \\
\hline OESP & $\begin{array}{l}\text { Integração empresa-família, clima } \\
\text { organizacional, pesquisa junto a } \\
\text { clientes. }\end{array}$ & Qualidade Total (QGP) & Franco, F., Segouras, H., jun. 1994. \\
\hline Philips & $\begin{array}{l}\text { Programa piloto de saúde física e } \\
\text { mental }\end{array}$ & Promoção da saúde & $\begin{array}{l}\text { Revista Exame: É melhor prevenir do } \\
\text { que remediar, 1992:73. }\end{array}$ \\
\hline Philips-Walita & $\begin{array}{l}\text { Promoção da saúde, ergonomia, } \\
\text { segurança, assistência social.(ver } \\
\text { quadros anexos). }\end{array}$ & $\begin{array}{l}\text { Segurança, higiene e } \\
\text { medicina, serviço social e } \\
\text { manutenção social }\end{array}$ & Texto Interno - fev./1996 \\
\hline $\begin{array}{l}\text { Refinações de } \\
\text { Milho Brasil }\end{array}$ & $\begin{array}{l}\text { Prevenção à AIDS e programas } \\
\text { de saúde eventuais }\end{array}$ & Medicina do trabalho & Nagasawa, J. M., jun. 1994. \\
\hline Riocell & $\begin{array}{l}\text { Ações diversas não totalmente } \\
\text { delineadas visando à simbiose } \\
\text { entre empresa e empregados }\end{array}$ & $\begin{array}{l}\text { Produtividade, redução de } \\
\text { acidentes e do } \\
\text { absenteísmo }\end{array}$ & Jornal de Recursos Humanos, 1992. \\
\hline Schering-Plough & Campanha de qualidade de vida & Saúde & Jornal Gazeta Mercantil, 31/5/95. \\
\hline Schulumberger & Semana de qualidade e saúde & $\begin{array}{l}\text { Preservação do meio } \\
\text { ambiente }\end{array}$ & Atividade de Campo, 1993. \\
\hline Shell & $\begin{array}{l}\text { Programa VIVA, assistência a } \\
\text { aidéticos, diagnóstico clínico } \\
\text { sistemático, pós-trabalho }\end{array}$ & Saúde e integração social & Material institucional de 1993. \\
\hline $\begin{array}{l}\text { StihlTIHL Moto } \\
\text { Serras Ltda. }\end{array}$ & $\begin{array}{l}\text { Diagnóstico de satisfação em } \\
\text { QVT, baseado nos critérios de } \\
\text { Walton }\end{array}$ & Satisfação pessoal & Jornal de Recursos Humanos, 1992. \\
\hline Telebrás & $\begin{array}{l}\text { Treinamento conceitual e } \\
\text { comportamental }\end{array}$ & $\begin{array}{l}\text { Stress e qualidade de vida } \\
\text { no trabalho }\end{array}$ & Atividade de campo. \\
\hline Tenenge & $\begin{array}{l}\text { Estrutura e gestão de Saúde e } \\
\text { Segurança voltados para QVT }\end{array}$ & Saúde e Segurança & Relatório específico da empresa. \\
\hline Translor & $\begin{array}{l}\text { Remuneração, alimentação, boa } \\
\text { tarde Translor, Rádio Translor }\end{array}$ & $\begin{array}{l}\text { Relacionamento e } \\
\text { integração }\end{array}$ & $\begin{array}{l}\text { Coelho, R.M.H. ,Chun, Y.Y., jun. } \\
1994 .\end{array}$ \\
\hline Unilever & $\begin{array}{l}\text { Entrevistas pessoais sobre efeitos } \\
\text { da reestruturação nas } \\
\text { expectativas e comportamento } \\
\text { das pessoas }\end{array}$ & $\begin{array}{l}\text { Efeitos da reestruturação } \\
\text { na qualidade de vida das } \\
\text { pessoas na empresa }\end{array}$ & Puglia, D. , Sícoli, D. L., jun. 1994. \\
\hline
\end{tabular}


O levantamento acima foi realizado nos últimos três anos de forma exploratória, há centenas de outras empresas desenvolvendo programas de qualidade de vida associadas a saúde e segurança, que é o mais freqüente, mas também existem projetos de mudança de hábitos, que atuam com revisão da alimentação, hábitos de sedentarismo e relacionamento entre pares e chefias.

1.2.4 Fenômenos humanos e organizacionais 
O objetivo deste tópico é delimitar conceitos-chave que formam o ambiente da empresa e os desdobramentos na vivência da qualidade de vida no trabalho. Vivência como modo de pensar, agir e perceber em termos individuais, grupais e organizacionais.

O fenômeno básico das dimensões humana e organizacional é o significado do trabalho e o que pode significar para qualidade de vida das pessoas. Este é um tema constante entre filósofos, pesquisadores e trabalhadores. A definição de Marx (1890) para trabalho é a atividade que caracteriza-se pelo esforço planejado sobre a manipulação ou transformação da natureza.

Além do esforço físico e mental o trabalho representa para a pessoa a própria identidade e integração social. A compreensão do significado do trabalho. Dejours et allii (1993) analisam trabalho de forma mais simbólica:

"Atividade profissional não é só um modo de ganhar a vida - é também uma forma de inserção social onde os aspectos psíquicos e físicos estão fortemente implicados. O trabalho pode ser um fator de deterioração, de envelhecimento e de doenças graves, mas pode, também, constituir-se em um fator de equilíbrio e de desenvolvimento. A possibilidade da segunda hipótese está vinculada a um trabalho que permita a cada indivíduo aliar as necessidades físicas, o desejo de executar a tarefa."

Hoje, a flexibilização dos postos de produção traz a valorização da competência, que inclui o saber, o sentir e o fazer. Isto é, no know-how adquirido, de forma integral, pelo indivíduo em sua relação com o objeto de produção (Pagés, 1987), com autonomia de decisão sobre o planejamento da produção e a ênfase no trabalho em equipe. Esta performance pressupõe qualidade pessoal. 
Essa nova realidade provoca mudanças na relação do homem com a organização e também nas relações interpessoais e demanda trabalhos em equipe e a necessidade de mais autonomia e responsabilidade dos trabalhadores.

A qualidade pessoal é formada por pelo menos três aspectos fundamentais: necessidade de formação profissional-educacional diferenciada para o exercício da competência, busca de patamares que permitam esta capacitação e competitividade para a qualidade e superação das necessidades básicas de sobrevivência.

Leser de Mello (1988) afirma: "A dignidade pessoal do ser humano é frágil.”E ressalta que os aspectos tradicionais do reconhecimento social associados à força e a dignidade nem sempre são percebidos nos diversos níveis sociais, especialmente nos níveis mais oprimidos em que apenas "os reflexos mais pálidos" das luzes da cidade chegam aos que constróem o brilho e a durabilidade das civilizações.

Apresentam-se dessa forma três níveis de compreensão da Qualidade de Vida no Trabalho:

- nível individual por meio da expressão das necessidades pessoais, em uma nova condição de ética e expectativa de condições de trabalho;

- nível grupal, na dinâmica da interação em equipes, da familiarização com novos processos e tecnologias;

- nível organizacional, mediante construção da cultura organizacional com todas suas implicações relativas à gestão do potencial humano, visando 
ao desempenho e aos resultados competitivos. Para ser competitiva a empresa deve lidar:

a) Nível individual

Ao celebrar o contrato de trabalho, a pessoa, com sua identidade formada por fenômenos subjetivos e de relacionamento, acata normas e padrões organizacionais e passa a pertencer àquele sistema social de relações de produção. Expectativas da empresa freqüentemente focalizam a busca da produtividade. Produtividade obtida com investimento de energia física e psíquica sobre operações, tarefas e responsabilidades, que é a força de trabalho. Firma-se o contrato psicológico de trabalho, que é um comprometimento de acordo mútuo, silenciosamente definido pelas expectativas do empregador e do empregado (Meyer, in Bergamini, 1988), que pode ser mais bem visualizado na Figura 1.1.

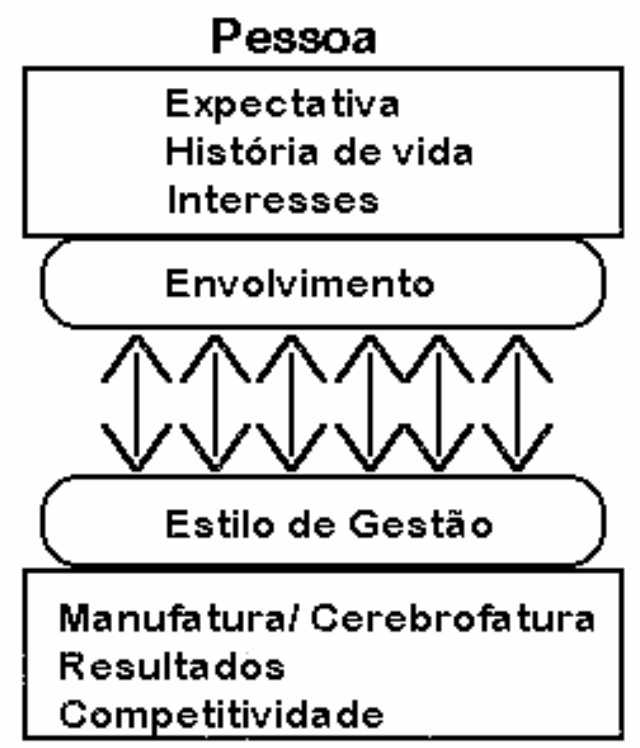

Empresa

Figura 1.1 Contrato psicológico de trabalho. 
Envolvem-se pessoas e grupos que se comprometem com o destino e o sucesso da empresa. Esse envolvimento deve estar em consonância com suas crenças, normas, valores. Estilos e critérios de comunicação institucional, localização dos poderes formais, alocação funcional e práticas gerenciais são os processos que mobilizam a dimensão humana do referencial da empresa.

O envolvimento para a obtenção de qualidade mobiliza desde a formação profissional-educacional diferenciada para o exercício da competência até a busca de patamares que permitam esta capacitação e competitividade.

Ferreira (1995) afirma que o envolvimento dos funcionários na implantação da Certificação ISO 9000 é um aspecto muito importante: "Devem participar e ser estimulados para isso". No entanto, não se pode esperar que as pessoas continuem contribuindo com suas idéias se não forem recompensadas por isso" (Osterman, in Tolovi, 1994).

Existe certa "miopia" no momento de se avaliarem as condições de vida no trabalho. É raro encontrar metas que envolvam melhorias efetivas das condições de trabalho, padrões de preservação da saúde física e mental, tecnologias que priorizem a adaptação do trabalho ao homem. Reais capacidades que muito provavelmente estão ligadas a potenciais intelectuais e emotivos, que sofrem constantes negações e sanções a partir de interações pessoais que, embora em nome da produtividade, pouco têm a ver com ela" Spink (1991). A nova visão de ser humano chega a ser ignorada ou percebida como um conceito imaginário de algo que vai ajustar espontaneamente. Isso raramente acontece. 
Em vez de envolvimento há desmotivação, que, segundo Meyer (1988), pode surgir em seis fases: confusão, raiva, esperança subconsciente, desilusão, falta de cooperação e partida. A desmotivação (Meyer, 1988) surge especificamente por falta de feedback construtivo, falta de informações significativas, falta de sensibilidade às necessidades individuais, falta de apoio comportamental ou psicológico, intromissão no trabalho (ou falta de autonomia). As soluções segundo a mesma autora são expandir plano de carreira, ampliar programas de treinamento, rever condições legais de desligamento, melhoria no bem-estar, por meio dos sistemas previdenciários e atenção aos avanços tecnológicos.

\begin{tabular}{c|c|c} 
PESSOA & $\begin{array}{c}\text { EMPRESA } \\
\begin{array}{c}\text { Realização } \\
\text { Identidade }\end{array}\end{array}$ & $\begin{array}{c}\text { Produção em longa } \\
\text { escala } \\
\text { Tecnologia } \\
\text { Impessoalidade }\end{array}$ \\
\hline & $\begin{array}{c}\text { CONSEQÜÊNCIAS } \\
\text { Auto-estima diminuída } \\
\text { Insignificância } \\
\text { Queda da produtividade } \\
\text { Conflitos } \\
\text { Insalubridade }\end{array}$ & \\
& $\begin{array}{c}\text { Inside } \\
\end{array}$ &
\end{tabular}

Figura 1.2 Conseqüências do desencontro de expectativas pessoa versus empresa.

b) Nível grupal 
O grupo influencia expectativas e legitima as articulações entre interesses individuais e empresariais. Por isso a reciprocidade é o ponto mais positivo desse nível porque mantém a estrutura do grupo. O estabelecimento de requisitos de qualidade e produtividade, em geral diferenciados entre os níveis hierárquicos operacional, gerencial e diretivo, gera fortes expectativas nos indivíduos.

O grupo torna-se referencial de legitimação dos modos de vida organizacional. A pessoa passa a pertencer a uma complexa rede de influencias operacionais, cognitivas, afetivas e organizacionais. Este tem sido o suporte da maioria dos programas de qualidade, que envolve mobilização e atividades de equipes, geralmente denominados times.

Schein (in Fleury, 1987) aponta para as experiências comuns a figura do fundador e a presença de várias subculturas, que se caracterizariam com base no background ocupacional de cada segmento da empresa. Neste background ocupacional encontra-se a parte (formadas por nível hierárquico ou de similaridade socioeconômica), que é muitas vezes "abortada, por causa da desvalorização de sua ação, diante da tirania simbólica do todo", não considerando que as pessoas vivem em seu quotidiano em micromundos, que representam partes deste mesmo todo (Spink, 1991).

\section{c) Nível organizacional}

Examina condições socialmente dadas, como ambiente físico e social favorável para a prática da co-responsabilidade e asseguramento dos procedimentos no mesmo patamar de qualidade e da melhoria do produto. 
Para implantar novo sistema de atendimento ao cliente via telefone, as empresas são obrigadas a rever seus procedimentos administrativos e operacionais, como modificar layout, melhorar iluminação, ter cadeiras ergonômicas, ventilação adequada etc. A implementação destas medidas parece ter colaborado para um ambiente favorável para expansão quanto à redução do absenteísmo, erros de atendimento e atitude favorável ao trabalho.

"Muitas formas de desperdício numa empresa são tão sutis que podem causar prejuízos enormes no correr dos anos, sem que sejam percebidos pelos seus dirigentes. Um caso típico desse desperdício é causado pela fadiga no trabalho. Ignorando os efeitos negativos da fadiga dos seus empregados, v. estará permitindo que parte dos lucros de sua empresa se diluam" (O Dirigente Industrial, março de 1964, p.27).

Esta afirmação sobre a fadiga e o lucro tem mais de três décadas e já trazia o conceito de desperdício; no entanto, só mais recentemente este importante aspecto da Qualidade de Vida no Trabalho vem sendo tratado com mais objetividade em função da pressão social e da valorização das pequenas variações de desempenho num posto de trabalho.

As classificações de envolvimento e condições socialmente dadas equivalem, respectivamente, à classificação de Herzberg (1985) motivacionais e higiênicas. No entanto, consideramos que as condições socialmente dadas têm desdobramentos motivacionais e vice-versa.

Muitos especialistas têm centrado suas análises relativamente à questão do potencial humano na gestão de equipes, redesenho de postos de trabalho, inter- 
relações entre atividades e processos (Workshop Internacional, 1994), mas muito pouco se vê em eventos voltados para "O caminhos das organizações" sobre condições humanas (expectativas $\mathrm{x}$ condições dadas) para realização de tarefas. Evoluímos pouco com relação à gestão e quantificação da qualidade da vida dentro da empresa, embora existam ferramentas para tal.

Uma constatação disso é o exemplo de Gonçalves (1994), que esclarece a definição de qualidade de Crosby - conformidade com os requisitos: "Quem se referir à qualidade de vida, por exemplo, precisa definir essa vida em termos específicos, como rendimentos adequados para se viver bem, saúde, controle da poluição, programas políticos e outros itens que podem ser mensuráveis."

O sistema homem-máquina tem seus limites. Para Wisner (1987), toda análise da relação home-máquina deve ser uma análise de inter-relações - no mesmo referencial de sistema (conjunto integrado de diversas unidades e processos), o que equivale a dizer que o estudo de condições de trabalho sob o enfoque ergonômico requer compreensão múltipla dos diversos níveis homemsistema e suas inter-relações estruturais, técnicas, econômicas e sociais.

Handy (1995:18-36) afirma que o trabalho nestes tempos de competitividade ficou mais problemático. Para ele, uma parte do problema é o dinheiro: "Nossas empresas querem o maior trabalho pelo menor pagamento, enquanto os indivíduos de modo geral querem o máximo de dinheiro, pelo menor trabalho, não é difícil de perceber que a empresa terá êxito". O dinheiro, segundo o autor, traz a exportação de mão-de-obra improdutiva, a necessidade de os improdutivos viverem também como cidadãos e por fim chega-se ao paradoxo de que nenhuma 
mão-de-obra, é melhor do que o trabalho ruim; por isso a mão-de-obra qualificada, embora dispendiosa, é necessária às empresas.

A missão fundamental dos gestores de Recursos Humanos é criar um clima propício à motivação e ao desenvolvimento das pessoas. Para Gaudêncio (1993), é preciso um algo mais na gestão das pessoas. Elas não podem ser coisificadas apenas na questão imediata da competência. Para ele, o trabalho deve ser um lugar onde o profissional tome consciência do que é dignificante e do que é apenas coisificante: ser submetido à revista ao passar pela portaria é coisificante; preocupação da empresa com sua saúde é dignificante. Assim, a qualidade de vida é subproduto do aumento de produtividade.

Aspectos objetivos da gestão de pessoas não podem ser ignorados do ponto de vista da Gestão da Qualidade de Vida no Trabalho. Nesse caso, estão análise do absenteísmo, levantamento das demandas de transporte, programas de educação alimentar, habitação, doenças, como alcoolismo, drogas, câncer, AIDS etc. O absenteísmo tem sido um grande sinalizador das demandas organizacionais. Couto (1987) faz extensa análise das condições e possibilidades de intervenção para o controle do absenteísmo. Apesar de interferir na produtividade e no desempenho individual, o absenteísmo é um excelente material de diagnóstico e propostas de melhorias na gestão de pessoal.

A Era da Qualidade agrupa os dois focos: pessoas voltadas para o cliente, com visão estratégica, automotivação e co-responsabilidade, conforme descrito na Figura 1.3. 


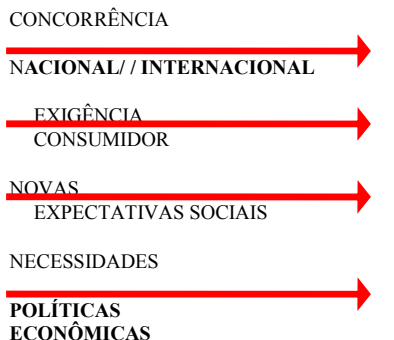

ECONÔMICAS

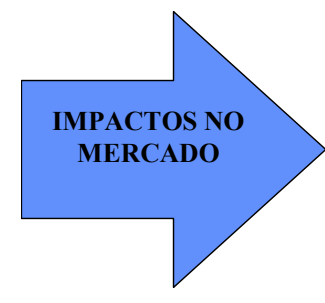

\section{SERVIÇOS}

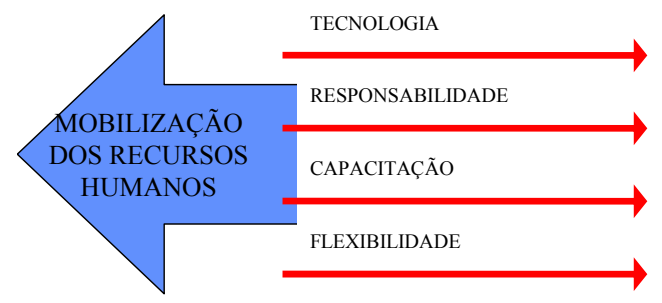

Figura 1.3 Empresas competitivas

Considere-se que todos os esforços empresariais devem conduzir à realização humana e ao bem-estar do empregado, isto é, a qualidade só terá sentido se gerar qualidade de vida (metaqualidade), isto é, a qualidade superior que leva a vida com qualidade. Como referência, apresentamos na Tabela 1.1 as chaves de satisfação no trabalho de Bolles (1981). São pontos de referência para a avaliação da performance da qualidade de vida no trabalho. As chaves são baseadas nos processos de qualidade, tempo, iniciativa, adaptabilidade, comunicação.

Tabela 1.1 As oito chaves de satisfação no trabalho.

\begin{tabular}{|c|c|}
\hline Chaves & Descrição \\
\hline $\begin{array}{l}\text { 1. Aqueles "acima" de nós no } \\
\text { trabalho }\end{array}$ & $\begin{array}{l}\text { O chefe, supervisores administrativos; os objetivos, } \\
\text { regras, procedimentos que eles estabelecem para a } \\
\text { organização (SOP). }\end{array}$ \\
\hline 2. Nossas questões & $\begin{array}{l}\text { A organização nos ajuda (ou não) a conhecer o que está } \\
\text { acontecendo, a sobrevivência, o sentido de missão ou } \\
\text { significado, eficiência etc.). }\end{array}$ \\
\hline 3. Nossa personalidade & $\begin{array}{l}\text { Como somos tratados, valorizados, considerados nas } \\
\text { tomadas de decisão, no conhecimento dos resultados, } \\
\text { se recebemos feedback, treinamento e promoção. }\end{array}$ \\
\hline 4. Nossas recompensas & Dinheiro, reconhecimento, férias, ajuda para crescer. \\
\hline
\end{tabular}




\begin{tabular}{|l|l|}
\hline & \\
\hline 5. A natureza da organização & $\begin{array}{l}\text { O que ele está tentando fazer e como está fazendo. Sua } \\
\text { estrutura, procedimentos, regras, espíritos. }\end{array}$ \\
\hline 6. Nossa programação & $\begin{array}{l}\text { Horários, tarefas, reuniões, interrupções etc. Tempo para } \\
\text { reflexão. Tempo para planejamento, trabalho noturno, } \\
\text { tarefas prescritas versus tarefas de preferência }\end{array}$ \\
\hline 7. Aqueles além de nós no trabalho & $\begin{array}{l}\text { Colegas e os que desempenham as mesmas tarefas e } \\
\text { nossos clientes. Como eles trabalham conosco, que tipo } \\
\text { de pessoas são e como nos tratam. }\end{array}$ \\
\hline 8. Nossas instalações físicas & $\begin{array}{l}\text { Localização, layout, recursos, acesso espacial ao } \\
\text { transporte externo. }\end{array}$ \\
\hline
\end{tabular}

Fonte: Bolles, 1981:85 (adaptação do original em inglês).

A partir do exposto neste item, o caminho da qualidade e competitividade deve ser construído junto com a qualidade de vida. No sentido de reduzir existe distância entre o discurso e a prática do que seria o bem-estar das pessoas. Este conceito é proposto por Albuquerque (1995), quando afirma que, filosoficamente, todo mundo acha importante, mas na prática prevalece o imediatismo, e os investimentos de médio e longo prazos são esquecidos. Tudo está por fazer. Qualidade de Vida no Trabalho é uma evolução da Qualidade Total. É o último elo da cadeia. Não dá para falar em Qualidade Total se não abranger a qualidade de vida das pessoas no trabalho. O esforço que se deve desenvolver é de conscientização, preparação de postura para a qualidade em todos os sentidos - produção, serviço, qualidade de vida no trabalho, é um estado de espírito. É necessária a coerência em todos os enfoques. 


\subsection{COMPETITIVIDADE, QUALIDADE E}

\section{ISO 9000}

"Se o progresso econômico significa que nos tornamos meras engrenagens de uma grande máquina, então o progresso é uma falsa promessa." Charles Handy

1.3.1 Competitividade: da sobrevivência às implicações éticas 
A busca de competitividade é um fato no Brasil. Muitos artigos, relatos e estudo de caso fazem parte da vida empresarial. Na busca da satisfação integral de uma necessidade, em determinados padrões de conformidade e eficácia as empresas organizam-se para ações diversas que atendam ao ambiente externo e à integração com o ambiente interno.

O relatório do The World Competitiveness Report (1995) afirma que a competitividade pode ser avaliada sob oito perspectivas. Estes fatores descrevem não só a viabilidade da empresa, mas também a competitividade do ambiente de competitividade. Segundo o relatório, a competitividade da empresa não pode ser separada do meio ambiente em que atua.

Os fatores apontados são: robustez da economia doméstica, internacionalização, governo, finanças, infra-estrutura, administração, ciência e tecnologia e habitantes. Entre os 48 países analisados, o Brasil encontra-se nas seguintes posições nestes fatores:

\section{Fator}

Robustez da economia doméstica

Internacionalização

Governo

Finanças

Infra-estrutura

Administração

Ciência e Tecnologia

\section{Classificação}

$44^{\circ}$

$36^{\circ}$

$25^{\circ}$

$37^{\circ}$

$37^{\circ}$

$32^{\circ}$

$29^{\circ}$ 
Na média geral, o Brasil está na $34^{\mathrm{a}}$ posição. O aspecto Qualidade de Vida no contexto da Competitividade Mundial é tratado como um subfator da perspectiva "Habitantes", e está classificado em 38․ Neste fator incluem-se também os subfatores: característica populacional, característica da força de trabalho, emprego-desemprego, estrutura educacional e atitude da força de trabalho. Outro fator tratado no relatório também relacionada aos recursos humanos é The worker motivation, em que o Brasil aparece em 26 임 luar no que se refere à identificação efetiva com os objetivos da companhia. Assim, em relação aos padrões internacionais de competitividade, o Brasil tem muito a caminhar.

Tsukamoto (1992), referindo-se a exigências para um crescimento sustentável do Brasil, afirma: "O PIB brasileiro, se comparado ao PIB de outros países, pode ser considerado um PIB pobre e de baixa qualidade, pois a economia brasileira incorpora incontáveis exemplos de desperdícios que se refletem, em última instância, no empobrecimento qualitativo do PIB e na queda da qualidade de vida do país. Esta conclusão envolve a adoção de exigências relativas ao controle do desperdício na produção, ineficiência no atendimento ao consumidor e por barreiras institucionais."

A competitividade exige novas visões desafiadoras com relação a teorias de produção, finanças, marketing e, especialmente, promoção do desenvolvimento econômico, conforme o pensamento de Zaccarelli (1995). Com o mesmo conceito 
de evolução, Tsukamoto apresenta no Quadro 1.7 as megatendências socioecônomicas.

Quadro 1.7 Megatendências econômico-sociais

\begin{tabular}{ll}
\hline Economia do ter_ & Economia do ser \\
Acúmulo de bens & Satisfação e bem-estar \\
Imposição do fabricante & Vontade do consumidor
\end{tabular}

Fonte: Extraído de TSUKAMOTO, Y. Projeto: núcleos de gestão para novos empreendimentos. São Paulo, ago. 1992. Apostila.

A competitividade é motivada para viabilizar a sobrevivência da empresa. Mas "esta luta pela sobrevivência pelo homem nem sempre conduz o homem ao comportamento ideal. A luta pela sobrevivência é eminentemente egoísta" (Kehl, 1994). Por isso, a ética se faz necessária.

A noção de competitividade relaciona-se a "uma participação bem sucedida no mercado internacional, possível de ser avaliada em três níveis: estrutural, setorial e empresarial" (Marcovitch, 1995). A empresarial, segundo o mesmo autor, refere-se à "capacidade das empresas em sustentar os padrões mais elevados de eficiência, vigentes no mundo, quanto à utilização de recursos e à qualidade de bens e serviços oferecidos. Uma empresa competitiva deve ser capaz de projetar, produzir e comercializar produtos superiores aos oferecidos pela concorrência, tanto em relação a preço quanto à qualidade”. 
Porter (1980:20) afirma que "o sucesso ou fracasso de qualquer empresa dependem da vantagem competitiva - ofertando o produto mais baixo ou oferecendo benefícios únicos ao comprador que justifiquem o preço. (...) A cultura é um meio para alcançar uma vantagem competitiva, e não um fim em si mesmo".

Para o autor, "uma meta de redução de custos totais ou políticas de pessoal a nível de toda a empresa podem ser desvantajosas para uma unidade empresarial que está procurando diferenciar-se na qualidade e no serviço.

Falconi (1992) afirma que ser competitivo é ter maior produtividade que os seus concorrentes e que a qualidade é um valor agregado à competitividade. As empresas não são mais ou menos competitivas - elas estarão mais ou menos competitivas. Já Collins e Porras (1995) consideram que os lucros são como o oxigênio, a comida, a água e o sangue para o corpo. Eles não são o sentido da vida, mas sem eles não há vida. Nesta interdependência, a exigência da lucratividade para a sobrevivência tem levado a um novo conjunto de esforços. Estes esforços geram impactos de modernização, conforme descritos na Figura 1.4.

\begin{tabular}{|ccc|}
\hline TECNOLOGIA & $\Leftrightarrow$ & DESEMPREGO \\
NOVOS DESENHOS ORGANIZACIONAIS & $\Leftrightarrow$ & ESVAZIAMENTO DE CARGOS \\
NOVAS FRONTEIRAS & $\Leftrightarrow$ & INSEGURANÇA \\
ESTILOS DE PODER & & \\
INTERNACIONALIZAÇÃO & $\Leftrightarrow$ & DESPERSONALIZAÇÃO \\
EMPRESAS VIRTUAIS & $\Leftrightarrow$ & UNIDADES DE NEGÓCIOS \\
\hline
\end{tabular}


Figura 1.4 Impactos da modernização.

Em decorrência desta modernização, as empresas têm incorporado vários tipos de intervenções: reengenharia, redesenho organizacional, redução de níveis hierárquicos, estruturas matriciais, células de produção e outros tantos visando à flexibilidade e aos custos competitivos. O foco é o cliente, dentro e fora das fronteiras tradicionais, mas para isso é necessário contar com a performance humana.

Em função disso observa-se um processo de evolução nos modelos e estratégias de competitividade. Vários autores indicam-no, entre eles Marcovitch (1995):

“Da racionalização do trabalho à produtividade, à gestão da inovação, à estratégia empresarial e finalmente à competitividade, seguiu-se um longo caminho. Um caminho semeado de barreiras que organizações e empresas tiveram que superar"

O gereciamento da qualidade, especialmente a ISO 9000, tem sido um dos procedimentos mais freqüentes em todo o mundo, a começar pelas intenções do mercado comum europeu de acelerar e proteger a integração econômica européia.

Na dimensão de uma cultura oriental e também com visão organizacional mais abrangente está a Gestão da Qualidade Total. Quando importada para o ocidente, a idéia central é de que "as empresas poderiam dispor da mesma para enfrentar a crescente concorrência dos produtos japoneses - vencer os japoneses com suas próprias armas" (Abramczuk, 1996). 
Esforços e competências estão adquirindo novos significados. Algumas vezes, a ênfase em resultado compromete o resultado maior de atender à condição humana de vida.

A ética na qualidade, segundo Cerquinho (1994), envolve a reflexão sobre os processos de adaptação do homem ao trabalho e do trabalho ao homem, a responsabilidade social e o conceito de bem comum, "conjunto de condições e de ajudas mútuas que tornam possível a todos alcançarem a sua perfeição enquanto seres humanos". O que inclui bens materiais, vida cultural e a valorização das qualidades pessoais e o conceito ético de ações e comportamentos empresariais bons ou maus.

Schumacher (In: Harman e Hormann, 1990) entre outros aspectos questionáveis da moderna sociedade industrial aponta sua natureza complicada que tende a enfraquecer o indivíduo. Roitman (1996) analisa os aspectos éticos da globalização e indaga: O que diria Aristóteles da globalização? O que o trabalhador faz com a noção de ética aristotélica, que preconiza a vida feliz, quando seu emprego está ameaçado pela competitividade de produtos que vêm do outro lado do mundo, sem lhe dar chance alguma de lutar contra isso? A autora utiliza a definição de Reckur para afirmar que "viver eticamente seria desejar a vida verdadeira com e para o outro nas instituições justas".

No escopo da competitividade - via modernização -, muitos pesquisadores têm denunciado as dificuldades do enquadramento do ser humano nesta nova lógica de estrutura e valores. 
Guerreiro Ramos (1989) aponta as limitações dos modelos competitivos baseados no mercado e propõe a ordenação de negócios sociais e pessoais tanto numa microperspectiva, quanto numa macroperspectiva. A idéia central é compreender organizações com elementos das exigências ecológicas. Neste modelo, a variedade de sistemas sociais constitui qualificação essencial em qualquer sociedade - o que ele denomina paradigmas paraeconômicos -, sistemas que também compõem a sociedade e não a tornam centrada só no mercado.

Aqui, situa-se o conceito de metaqualidade, criado por Kehl (1995), em que a qualidade incorpora o conceito de justiça social e passa a ser instrumento da qualidade de vida. Metaqualidade exige mais do que um produto ou serviço tecnicamente perfeito, uma manufatura eficiente, ou um procedimento administrativo eficaz; sobrepuja a simples satisfação das necessidades e desejos dos atuais usuários e consumidores.

Os pré-requisitos das organizações competitivas são:

- Foco no mercado e no perfil do cliente.

- Meios de produção mais sofisticados.

- Superação das necessidades básicas de infra-estrutura.

- Garantia do bem-estar individual.

- Compromisso com a qualidade.

- Valorização da ética nas relações de trabalho.

Metaqualidade envolve a busca de soluções empresariais adequadas a cada realidade social, de modo a garantir criativa e eticamente a sobrevivência das organizações. 


\subsubsection{Gurus da Qualidade: idéias e conceitos}

Moreira (1994) define qualidade como "um atributo de produtos, de serviços, mas pode se referir a tudo que é feito pelas pessoas". Aponta os seguintes elementos básicos da gestão total de qualidade: cliente, técnicas e ferramentas e cultura organizacional adequada a promover a auto-estima das pessoas, a confiança dos funcionários na gerência e vice-versa, a criação e manutenção de um ambiente de trabalho cooperativo.

Para Abramczuk (1996), "qualidade é o nome que se dá ao conjunto de atributos evidenciados por algo que corresponda a uma expectativa de desempenho".

Falconi (In Gonçalves, 1994) ensina que qualidade de um produto ou serviço está diretamente ligada à satisfação total do consumidor e consta dos fatores: qualidade ampla, custo e atendimento. Para Rothey (1993), "Qualidade é adequação ao uso. É a conformidade às exigências. É o produto projetado e fabricado para executar apropriadamente a função designada”.

Hirata (1992) define qualidade como "conformação a uma norma (ou a uma série de especificações) a ser adotada pelo coletivo de trabalho". Inclui, também, o conceito de critério de qualidade, que é "colocar o produtor direto, no momento mesmo da fabricação, face ao problema da valorização (a visualização da expressão do usuário do produto, satisfeito ou não com a mercadoria)". 


\section{EMPREENDIMENTO E A QUALIDADE}

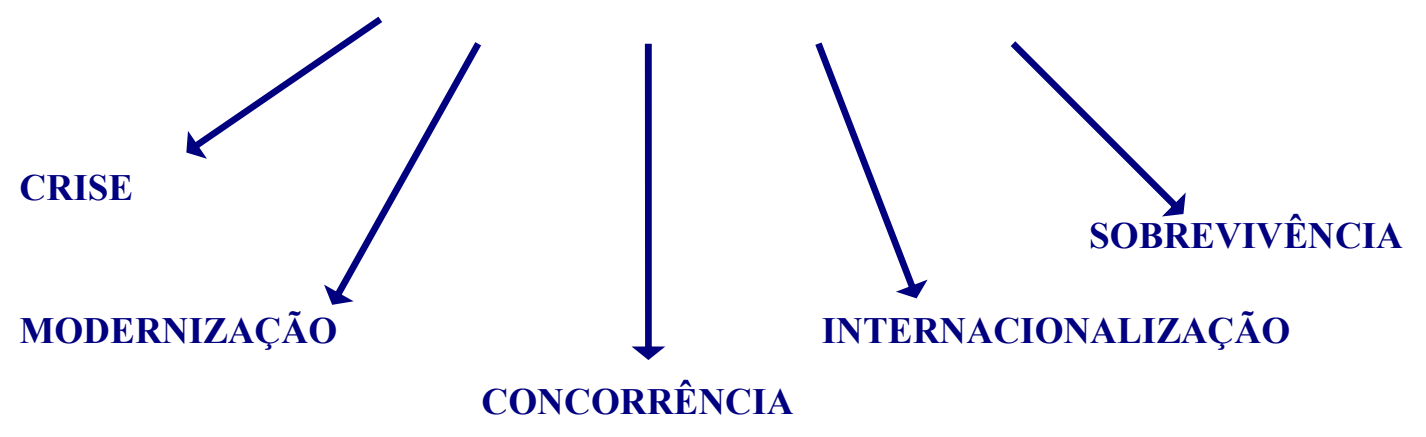

Figura 1.5 As pressões das empresas.

O modelo brasileiro de qualidade, segundo Quelhas (1996), está baseado na criatividade e na superação dos padrões rígidos da relação capital-trabalho aliadas à falta de visibilidade a curto prazo de que o mundo empresarial está mudando. Para alguns estudiosos do tema (Passos, 1996, Quelhas, 1996, Falcone, 1992, Abramczuk, 1996), a Gestão da Qualidade Total é uma realidade no Brasil. Passos (1996) afirma que pode ser considerada uma nova Teoria de Administração.

Esta nova Teoria de Administração envolve, segundo Hammer e Champy (1994:51-65), os seguintes processos de reengenharia:

Quadro 1.8 Processos de engenharia. 


\begin{tabular}{|l|l|}
\hline \multicolumn{1}{|c|}{ Situação atual } & \multicolumn{1}{c|}{ Situação vislumbrada } \\
\hline - Departamentos funcionais & - equipes de processos \\
- Tarefas simples & - tarefas multidimensionais \\
- Pessoas controladas & - pessoas autorizadas \\
- Treinamento de pessoas & - educação de pessoas \\
- Medidas: desempenho e remuneração & - atividades: para resultados \\
- Promoção por desempenho & - promoção por habilidade \\
- Valores culturais protetores & - valores culturais produtivos \\
- Gerência que supervisiona & - gerência que instrui \\
- Estruturas organizacionais hierárquicas & - estruturas organizacionais niveladas \\
- Executivos controladores de resultados & - executivos líderes \\
\hline
\end{tabular}

Fonte: Adaptado de Hammer e Champy (1994:51-65).

Em matéria das Maiores e Melhores (Exame, 1996), as empresas ali classificadas pouco ou nada enfatizam estas demandas de recursos humanos. $O$ mais específico que se relata é que a empresa vencedora neste ano utiliza bônus mensal, como forma de incentivo às metas estabelecidas. A ênfase neste ranking é financeira. Não que não se faça nada, mas habitualmente não se considera como fator competitivo e sim como obrigação necessária.

Os precursores do pensamento da qualidade tiveram uma influência significativa nas propostas de competitividade e gerenciamento das empresas. Selecionamos da revista Business Week (1991) em sua edição especial sobre "O domínio da qualidade" alguns aspectos que remetem às origens da competitividade da sociedade moderna, neste e no próximo século. Os editores remontam, aos primeiros programas, há aproximadamente seis décadas nos Estados Unidos, na Europa e no Japão. Estes programas são desdobramentos de uma nova mentalidade de negócios, que revoluciona todas as facetas do empreendimento. 
Os denominados "gurus" da qualidade, muitos de origem não-oriental e formação nos Estados Unidos, celebrizaram suas filosofias e modelos com base em resultados obtidos em empresas japonesas, que estão revolucionando o pensamento empresarial mundial.

A seguir são sintetizadas algumas das principais idéias destes "gurus", apontadas pela revista. O período mais acentuado de difusão destas idéias foi a partir dos anos 80. No Brasil surgem em torno dos anos 90, embora algumas multinacionacionais tivessem valores sobre qualidade total incorporados na prática gerencial nos anos 70 .

Deming (1990) propõe o controle estatístico, via reação em cadeia do controle do desperdício e da ineficiência. Com base nos 14 princípios de gerenciamento, propõe em seus programas de qualidade revolucionar o conceito de administração. Para ele, boa qualidade não é "alta" qualidade, mas um grau previsível de uniformidade e confiabilidade, a baixo custo, adequado ao mercado, em que o referencial é o controle estatístico da qualidade que deve gerar a redução de variância e do ciclo de fabricação do produto.

Juran (1991, edição brasileira), inicialmente parceiro de Deming, incorpora na administração o conceito de gerenciamento de projetos, fundamentado em 10 princípios para a melhoria da qualidade. Estes princípios devem ser práticas adotadas por equipes de projetos, apoiadas por conselhos de qualidade e especialistas devem buscar "não conformidades" crônicas e reorganizarem todo processo interno e externo da empresa, via planejamento e projetos. 
Crosby (1990) traz uma abordagem preventiva: preconizar uma "vacina" de qualidade e o defeito zero, através da clareza de especificações. Seu principal referencial para qualidade é "conformidade" versus "não conformidade". O zero defeito não é centrado na motivação de pessoal, mas no padrão de desempenho gerencial. Ele propõe 14 passos para Melhoria da Qualidade, centrados em atitudes gerenciais internas e externas à empresa.

Ishikawa (1985), o "pai" do CCQ (Círculos do Controle de Qualidade), criado em torno de 1960, integrante da JUSE - União dos Cientistas e Engenheiros Japoneses, é um articulador gerencial de toda cultura oriental de participação e compromisso com o trabalho. Criou o Diagrama de Causa e Efeito (Espinha de Peixe), largamente utilizado nos Círculos de Controle da Qualidade.

Taguchi criou em Tóquio, durante os anos de 1950, os processos estatísticos de controle da produção - CEP, modificando especialmente a função do supervisor de primeira linha, com métodos simples de experimentação por planos de experiência. Seu conceito chave é o do desenvolvimento "robusto" de produtos, desde o projeto até o uso de métodos estatísticos avançados para análise de oscilações na produção.

Fergenbaum, também em 1950, cria nos Estados Unidos os Sistemas de Qualidade Total, voltados para qualidade no gerenciamento dos negócios. Criou os primeiros conceitos de garantia da qualidade. Especializou-se em desenvolvimento de sistemas operacionais de qualidade.

Imai (1986), radicalmente oriental, difunde a partir de 1950 toda filosofia japonesa do melhoramento contínuo: o Kaizen (mudanças positivas). O objetivo é 
realizar mudanças passo a passo no processo de manufatura ou na área administrativa e garantir o melhoramento contínuo da economia da empresa.

Dele decorre o JIT - just in time, que engloba novas operacionalizações e critérios de demanda de estoque, armazenagem e fabricação, como o uso do Kanban e dos CCQ.

As características da gestão japonesa para qualidade - modelo de referência para a maioria das empresas ocidentais - têm sua diferenciação nas seguintes características apontadas por Fleury e Fleury (1995:71):

"A importância atribuída ao desenvolvimento do empregado, como recurso fundamental para consecução das estratégias organizacionais; a importância do desenvolvimento do trabalho em equipes; a gestão da cultura para o sucesso organizacional."

A gestão da qualidade em qualquer de seus sistemas gerou nova lógica da organização dos processos de produção. As características mais significativas são:

- necessidade da explicitação das características reais das tarefas;

- novas seqüências de ciclos produtivos;

- eficácia e adequação das máquinas e equipamentos;

- eliminação de riscos;

- controle e reparação de riscos;

- valorização da sabedoria de quem faz.

Destas características e de pelo menos mais uma centena de gurus e especialistas formou-se uma massa cultural sobre uma nova mentalidade de 
gestão da produção nas empresas. As implicações nas relações de trabalho estão em pleno processo de construção, ajustes e algumas vezes negação.

Wood Jr. (1995:228) detalha os impactos característicos dos programas de qualidade em fases evolutivas desde o momento de inspeção à transformação profunda das práticas gerenciais. 


\subsubsection{Sistema de certificação ISO 9000}

O desenvolvimento industrial e o avanço tecnológico geraram produtos que apresentam maior grau de complexidade, exigências quanto a padronização, confiabilidade e segurança operacional. A globalização dos produtos e a idéia de requisitos asseguraram a constância da qualidade do produto, consolidando a promulgação da ISO 9000.

Os requisitos de qualidade não estão apenas nas normas ISO 9000. O que a diferencia de outros sistemas de normatização é seu forte cunho mercadológico. As características essencialmente documentais exigem a elaboração do manual da qualidade, documentos de procedimentos, instruções de trabalho, formulários, arquivos, documentos e registros. As áreas-chaves da estruturação desta documentação são: marketing, projetos, compras, produção, custos e treinamento. Os motivos mais freqüentes da necessidade vislumbrada pelas empresas para buscar a certificação são (Rotondaro e Lopes, 1994):

- exigência dos clientes;

- exigência do mercado externo para exportação;

- maior formalização do sistema da qualidade;

- exigência do governo federal - redução de impostos;

- ordem da matriz. 
A certificação também tem sido motivada por exigência de grandes clientes de internacionalizar a comercialização do produto e de garantir a credibilidade ao produto em termos de marketing.

A Normatização da série ISO 9000 (Parada, 1991) foi implementada em 1987 depois de 10 anos de trabalho do Comitê Técnico 176 da Organização Internacional de Normatização (ISO), sediada em Genebra, Suíça - fundada em 1947. As normas ISO são uma série de cinco normas que compõem documentos que descrevem sistemas de qualidade. Estas normas foram trazidas para o Brasil em 1989 pela ABNT- Associação Brasileira de Normas Técnicas. Mais de 90 países adotaram a série ISO como referência de Sistema de Qualidade. O ISO Council Commitee on Conformity Assessment - CASCO tem determinado novas atualizações visando à credibilidade e crescente internacionalização da norma. Atualmente, conta pelo menos 92 países participantes.

A implantação do Sistema de Qualidade ISO 9000 permite uma gestão mais ordenada e sistematizada do processo de qualidade, embora muitas vezes a empresa esteja documentada e burocratizada.

O reconhecimento da adoção dos requisitos de qualidade da série ISO 9000 é dado por instituições certificadoras, que emitem o certificado após auditorias específicas. Atualmente, existem 20 instituições certificadoras - 16 estrangeiras e 4 nacionais (Sócio, 1995). Esta certificação é revalidada a cada seis meses, com novas auditorias. O processo de implantação pode demorar de dois a cinco anos.

Segundo Lee (1996), o grande mérito das normas ISO série 9000 foi "colocar uma ordem no caos existente entre diversas linguagens e exigências em termos 
de qualidade, definindo uma terminologia universal e requisitos da qualidade aceitos mundialmente pelos diversos setores econômicos, facilitando de forma ímpar as relações comerciais entre as nações, além de dar um grande impulso para a melhoria da qualidade e da competitividade das organizações”.

A Figura 1.6 mostra a estrutura das normas ISO para a qualidades.

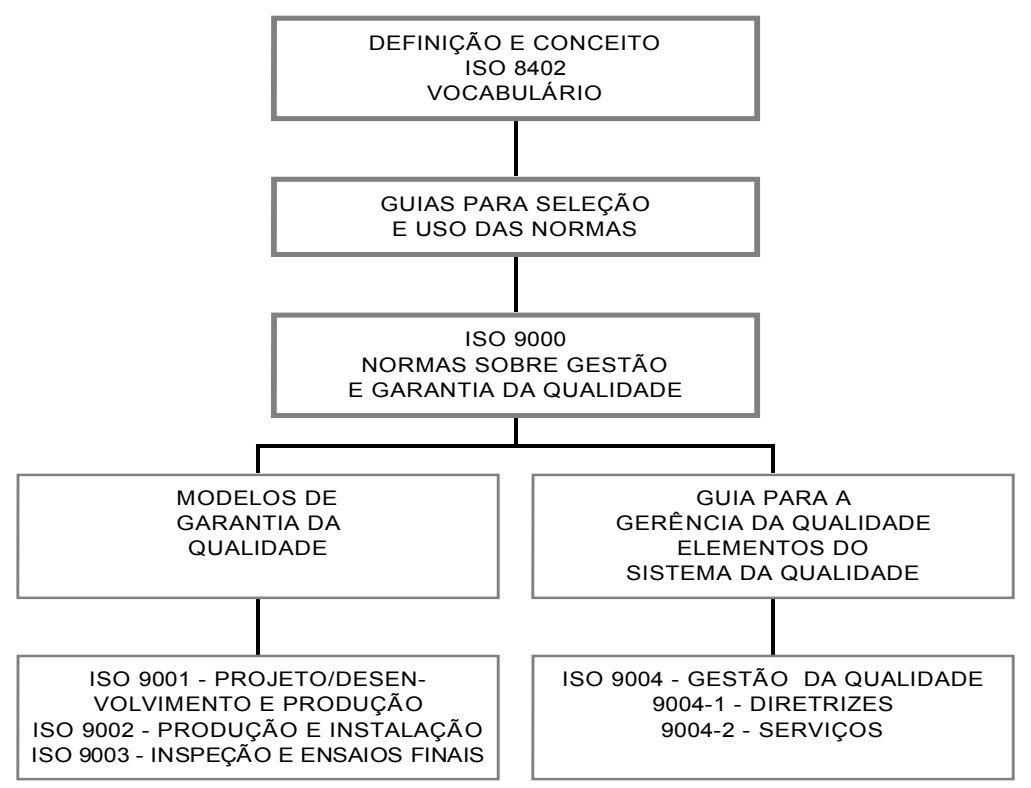

Fonte: Adaptada de Rotandaro e Fernandes (1993).

Figura 1.6 Estrutura das normas ISO para a qualidade.

A implantação dos requisitos visando à certificação em determinada norma da série ISO 9000 sofre fortes influências da cultura organizacional, da tecnologia utilizada, do padrão de qualidade já praticado. Para Tsukamoto (1996), a companhia precisa "impor alma na infra-estrutura voltada para qualidade. Não basta conhecer as técnicas, é preciso incutir o espírito da qualidade em toda gestão da empresa”. 
Até o final de 1997, cerca de cinco mil empresas devem buscar a certificação (In Parada, 1996). Esta situação, segundo o autor, gera "um amadurecimento quase imediato das empresas para qualidade". Mais adiante afirma: "É preciso que a certificação ISO 9000 possa colocar uma organização a caminho do aprimoramento assegurado, desencadeando uma mudança cultural que possa surpreender clientes, fornecedores, acionistas e os próprios concorrentes...Organizações amadurecidas quanto à qualidade têm recorrido às certificações ISO como uma cunha para evitar retrocessos em seus processos de melhoria." Outros autores são menos otimistas: Bueno (1996), por exemplo, diz que serão 1.500 até o final de 1996.

Até agosto de 1996, 901 empresas obtiveram 1.292 certificações, especialmente as manufaturas do setor industrial (ver Tabela 1.2). Até dezembro de 1995 , o Brasil estava em $22^{0}$ no ranking mundial, à frente do México $\left(215^{\circ}\right)$ e Argentina $\left(86^{\circ}\right)$. A Grã-Bretanha possui cerca de 30 mil certificações e o Japão 500.

As certificações exigem vários tipos de melhorias organizacionais e estão associadas à exigência dos clientes. No Brasil, especialmente os maiores exigentes são as montadoras e as empresas públicas. "Obter a certificação é uma questão de sobrevivência no mercado" (Ferreira ,1995).

Muitas vezes, estas melhorias resultam em redução de postos de trabalho, levando mais pessoas ao desemprego. Do ponto de vista positivo, as melhorias são investimento em educação e treinamento. 
Alguns problemas são claramente revelados nas crenças e nas práticas da certificação ISO 9000. Com base em dados de pesquisa elencamos os mais indicados na literatura, conforme Quadro 1.9.

Quadro 1.9 Problemas da ISO 9000.

\begin{tabular}{|l|l|}
\hline \multicolumn{1}{|c|}{ Problema } & \multicolumn{1}{|c|}{ Fonte } \\
\hline Armadilhas de significado: ISO ser sinônimo de excelência. & CYMBALISTA, M.,1995. \\
\hline Achar que só especialistas podem preparar a documentação. & Idem. \\
\hline Achar que se implanta ISO ou Qualidade Total. & Idem. \\
\hline O benefício da ISO é o certificado. & Idem. \\
\hline $\begin{array}{l}\text { Banalização da certificação, menosprezo às empresas } \\
\text { brasileiras certificadas e seu esforço para se tornarem } \\
\text { competitivas. }\end{array}$ & $\begin{array}{l}\text { FERREIRA, 95, Informe QSP, } \\
\text { ano V, n. 44, set/96. }\end{array}$ \\
\hline $\begin{array}{l}\text { Uso de veículos de marketing para "vender" a idéia da qualidade } \\
\text { apenas via certificação. }\end{array}$ & Idem. \\
\hline $\begin{array}{l}\text { Generalização da certificação de um produto para outros } \\
\text { aspectos da competência organizacional. }\end{array}$ & Idem. \\
\hline $\begin{array}{l}\text { Não avaliar que a certificação deve ser o mínimo que qualquer } \\
\text { empresa deveria ter, em termos de gestão da qualidade. }\end{array}$ & Idem. \\
\hline $\begin{array}{l}\text { A certificação demonstra aos cliente apenas um nível de } \\
\text { qualidade constante. }\end{array}$ & Idem. \\
\hline $\begin{array}{l}\text { A certificação é vista como um bem em si mesma, quando deve } \\
\text { ser o ponto de partida para a real competição do século 21. }\end{array}$ & $\begin{array}{l}\text { TSUKAMOTO, Folha de São } \\
\text { Paulo, 25 ago 96. }\end{array}$ \\
\hline $\begin{array}{l}\text { Credibilidade quanto ao cumprimento fiel dos requisitos exigidos } \\
\text { na Norma. }\end{array}$ & Idem. \\
\hline $\begin{array}{l}\text { A certificação não é garantia de sucesso de vendas e } \\
\text { exportações, é apenas um pré-requisito. }\end{array}$ & Mattei, Folha de S. Paulo, NBS. \\
\hline Rearranjo da empresa e redução dos postos de trabalho. \\
\hline $\begin{array}{l}\text { Resistência e falta de motivação para qualidade por parte dos } \\
\text { funcionários. }\end{array}$ & Rotondaro \& LOPES, 1994. \\
\hline
\end{tabular}

Há muita confusão sobre os resultados e serviços da certificação ISO 9000.

Os problemas citados mostram que é necessário muito cuidado em seu marketing e respectivas finalidades.

Além disso, confirma-se com freqüência a fantasia de que sistematizando os requisitos, as pessoas se transformaram positivamente naqueles mesmos 
requisitos. Estamos nos referindo à: valorização da qualidade, reconhecimento da existência dos clientes, não-desperdício, capacitação etc.

Os Programas de Premiação da Qualidade também fazem parte deste grande movimento de competitividade. Espalhados pelo mundo inteiro, os prêmio são de âmbito nacional, mas adotam critérios internacionais, especialmente os originados no Prêmio Malcolm Baldrige, dos Estados Unidos. No Brasil, a Fundação para o Prêmio Nacional da Qualidade existe há cinco anos e adotou os seguintes critérios:

- Liderança

- Informação e análise

- Planejamento estratégico

- Desenvolvimento e gestão de recursos humanos

- Gestão de processos

- Resultados do negócio

- Focalização no cliente e sua satisfação

As empresas que se candidatam ao Prêmio relacionam as características organizacionais que atendem aos requisitos, passam por auditoria específica e recebem uma pontuação que as orienta e as classificam diante das outras empresas candidatas-concorrentes. A mensagem simbolizada pelo troféu do Prêmio é: Vencendo Barreiras - mais uma busca de valor agregado à competitividade.

É usual comparar ISO 9000 com PNQ, mas o que se nota é que há um mesmo caminho a ser trilhado, conforme Figura 1.7, mas a ISO 9000 está bem aquém da Gestão da Qualidade Total; o que se tem é padronização de processo e 
produtos, o que se confirma com a presença da ISO 9000 nas manufaturas, especialmente no ramo de eletrônico e ótica, conforme detalhado no Quadro 1.10.

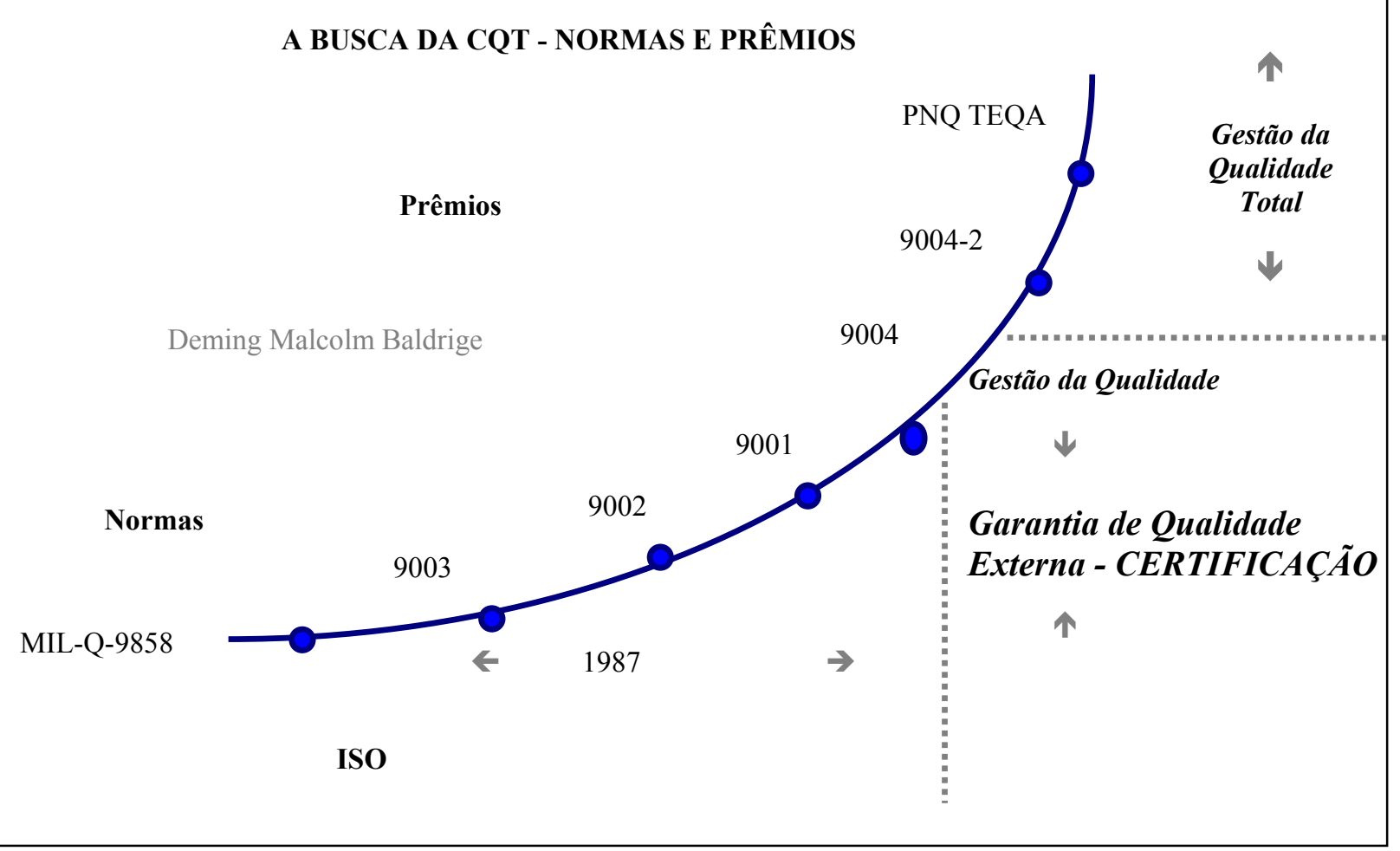

Figura 1.7 Trajetória da gestão da qualidade.

Fonte:Fundação para o Prêmio Nacional da Qualidade, 1994 
Quadro 1.10 ISO 9000 no Brasil

Área de Atuação

Número de certificados

Eletrônica e ótica 299

Química de base, produtos químicos e fibras sintéticas

Metais de base e produtos metálicos

179

Máquinas e equipamentos não especificados

Equipamentos de transporte

Atividades imobiliárias, locação e prestação de serviços

95

Produtos minerais não metálicos e outros

67

Artigos de borracha e de plástico

42

Comércio, conserto de veículos automotivos, bens pessoais 40

Celulose, papel, papelão e produtos, edição e impressão 40

Produtos alimentícios, batidas e fumo $\quad 35$

Intermediação financeira $\quad 32$

Transportes, armazenagens e telecomunicações $\quad \mathbf{2 1}$

Coque, refinados de petróleo e combustível nuclear $\quad 21$

$\begin{array}{ll}\text { Indústria extrativa (exceto produtos energéticos) } & 18\end{array}$

$\begin{array}{ll}\text { Construção } & 17\end{array}$

Indústria têxtil $\quad 13$

Educação $\quad 6$

Atividades de serviços sociais e comunitários $\quad 4$

Hotéis e restaurantes $\quad 4$

Indústria de transformação, outras

Extração de produtos energéticos 1

Madeira, cortiça e seus produtos 1

$\begin{array}{ll}\text { Agricultura, pecuária, caça, silvicultura } & 1\end{array}$

Saúde e serviço social

TOTAL $\left(^{*}\right) \quad 1.428$

$\left(^{*}\right)$ Obs: algumas empresas certificadas atuam em mais de uma área, até 06/08/96.

Fonte: CB-25 (Comitê Brasileiro de Qualidade - ABNT).

Os requisitos da ISO têm aplicabilidade em vários aspectos da Qualidade de Vida no Trabalho. Praticamente abandonada nos últimos anos, esta relação começa a apresentar sinais de interesse, tanto no âmbito da gestão da qualidade do produto para o cliente final, como na sinalização de necessidades de melhorias para o cliente interno e seu ambiente de trabalho. 
Rothery (1992:4) aponta um novo impulso europeu nas normas ISO, em função das novas regulamentações de segurança e saúde, onde começam a ser condensados procedimentos de preservação do meio-ambiente imediato, equipamentos de segurança, atendimento às emergências, características ergonômicas nos postos de trabalho.

Frosini e Carvalho (1995:53) propõem as seguintes coincidências com relação à ISO 90003 e as BS 5750 (parte) BS 7750 e BS 8750: clientes incluindose empregados e acionistas. Estes sistemas de gestão da qualidade convergem para um ponto fundamental: a sobrevivência da organização como entidade livre e próspera, uma necessidade que pode ser comparada ao instinto de sobrevivência de um ser humano ou de outro ser vivo. Os pontos comuns mais significativos são os que relatam controle dos efeitos ambientais e dos eventos perigosos. A cultura e a postura de uma organização que possui um Sistema Gerencial de Qualidade SGQ implementado contribui para enfatizar o envolvimento e o comprometimento que todos os funcionários devem ter com relação à segurança e à saúde. 


\subsubsection{Visão crítica da Gestão de Recursos Humanos para Qualidade}

Foram analisados neste bloco aspectos da competitividade associados à gestão da qualidade - o foco era estratégico, e à gestão da qualidade e à certificação ISO 9000 - o foco era organizacional. O último elemento desta análise será a questão gerencial da qualidade - com foco da gestão de pessoas.

Tragtenberg (1985) destaca que as teorias administrativas são dinâmicas e acompanham as formações socioeconômicas, cumprindo funções operativas, quando fazem a mediação entre a macrossociedade e a microorganização e funções genéticas, quando repõem as experiências acumuladas no espaço organizacional.

Lobos (1991) e Moreira (1995) colocam a gestão da Qualidade Total com os principais movimentos administrativos, enfatizando que TQM (Total Quality Management) é basicamente uma filosofia gerencial, que tem como foco permanente o cliente.

Hamel e Prahalad (1995) afirmam que na competição para o futuro, os gerentes são administradores e não proprietários dos recursos humanos fundamentais - esta seria a via de acesso para reciclagem de recursos. O que parece evidente, na prática funciona como hipótese: a individualização do desempenho dentro de unidades de negócios, a explicitação ou "construção conjunta" de aspirações de todos os funcionários no processo competitivo e a recíproca sobre a esperança na empresa de que esta aspiração vai significar um 
ganho positivo pessoal e tangível é proposta de gestão avançada. Na prática só é verbalizada. A causa disso pode ser a ausência de ferramentas e investimento gerencial e financeiro nesta "construção de aspirações individuais e coletivas".

“Uma organização inovadora necessita de indivíduos que se sintam apaixonados em perseguir descobertas”. Herzberg (in Bergamini, 1988) enfatiza a necessidade de liberdade interna para gerar idéias inovadoras. Neste processo encontra-se a aprendizagem contínua como fator da atitude competitiva no trabalho, hoje fundamental com horizonte de crescimento de qualquer organização. Fleury e Fleury (1995) relatam os processos de aprendizagem organizacional nas culturas do Japão, da Coréia e do Brasil.

Storey (in Fleury e Fleury, 1995) identifica dois aspectos neste último fator: o hard, relativo aos aspectos quantitativos de administrar recursos humanos de forma racional, objetivando a estratégia do negócio, e o soft, relativo a comunicação, motivação e liderança.

O elo da viabilização da aprendizagem e inovação para competitividade com modernidade pode ser a participação. Grau de influência dos empregados, níveis organizacionais de participação e as questões que compõem o escopo são, segundo Albuquerque (1992 a e b, 1996) os elementos da gestão participativa (ver Quadro 1.8). 


\section{GOVERNO - SINDICATOS - FORNECEDORES - TECNOLOGIA - CLIENTES - CONCORRÊNCIA - MERCADO DE TRABABALHO}
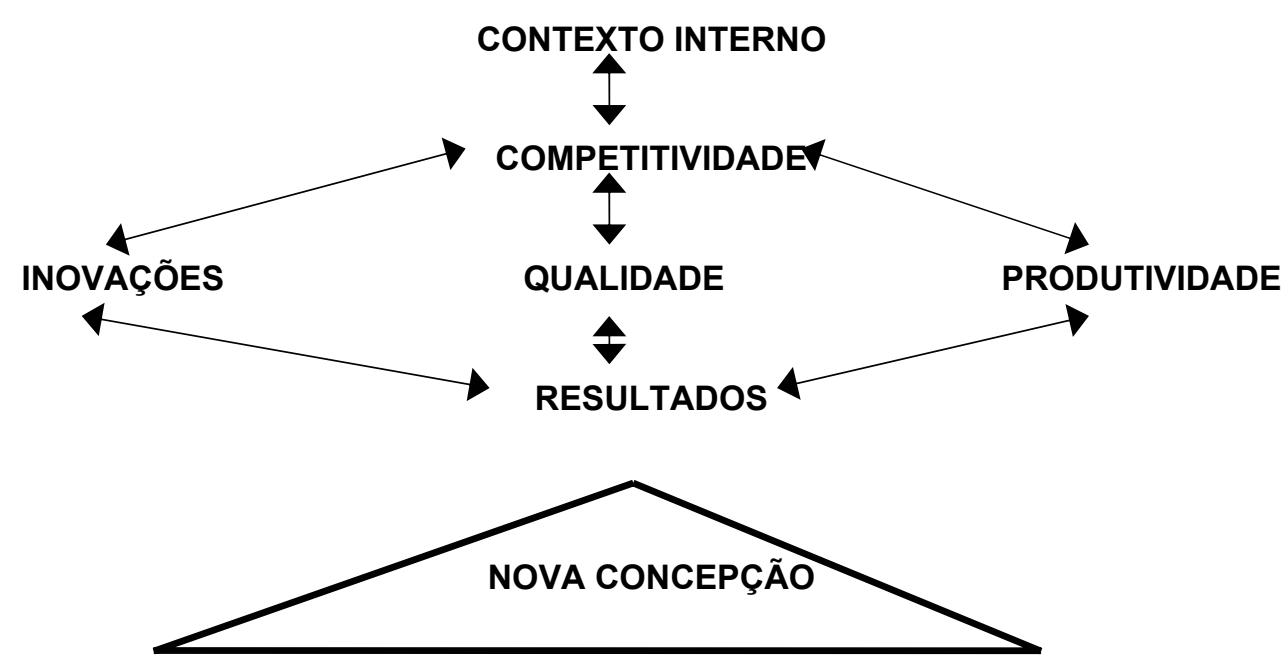

\section{RELAÇÕES DE TRABALHO}

- Qualificação e desenvolvimento

- Emprego mais duradouro

- Trabalho em grupo, participação e comunicações

- Relações com sindicatos, convergência de interesses
POLÍTICAS DE RECURSOS HUMANOS

- valorização dos talentos humanos

- Atração e manutenção de pessoas

- Motivação e mobilização

- Crescimento funcional

- Incentivos de base grupal

- Políticas integradas

\section{CONTEXTO EXTERNO}

Fonte : Transcrição de Lindolfo Galvão de Albuquerque, 1992 A/B, p.85.

Figura 1.8 Modelo de gestão de recursos humanos e relações de trabalho para a empresa competitiva.

A participação foi pesquisada por Rabelo (1995), que concluiu que "as empresas mais bem colocadas em termos de gestão da qualidade foram justamente aquelas que tinham avançado mais em termos do grau de participação dos funcionários".

No Brasil, ocorreram fases típicas de práticas de Gestão de Recursos Humanos, como detalha Wood Jr. (1995:233), no Quadro 1.11, onde se observa a 
evolução do conceito de rotinas de pessoal para gestão sistemas de pessoas. $\mathrm{Na}$ prática, temos empresas brasileiras com características heterogêneas em todas estas fases.

Quadro 1.11 Prática da gestão de RH no Brasil.

\begin{tabular}{|c|c|c|}
\hline Período & Fase & Característica \\
\hline Antes de 1930 & Pré-jurídico-trabalhista & $\begin{array}{l}\text { - Inexistência de legislação trabalhista e de } \\
\text { departamento pessoal. } \\
\text { - Descentralização das funções. }\end{array}$ \\
\hline Décadas de 30 e 50 & Burocrática & $\begin{array}{l}\text { - Advento da legislação trabalhista. } \\
\text { - Surgimento do departamento pessoal para } \\
\text { atender às exigências legais. }\end{array}$ \\
\hline Décadas de 50 e 60 & Tecnicista & $\begin{array}{l}\text { - Implantação da indústria automobilística. } \\
\text { - Implementação dos subsistemas de RH. } \\
\text { - Preocupação com a eficiência e desempenho. }\end{array}$ \\
\hline $\begin{array}{l}\text { Meados da década de } \\
60 \\
\text { Décadas de } 80 \text { e } 90\end{array}$ & Sistêmica & $\begin{array}{l}\text { - Surgimento da gerência de RH e do } \\
\text { responsável de relações industriais. } \\
\text { - Integração dos enfoques administrativo, } \\
\text { estruturalista e comportamental. }\end{array}$ \\
\hline & & $\begin{array}{l}\text { - Reformas estruturais profundas. } \\
\text { - Migração da FRH para as áreas operacionais. } \\
\text { - Surgimento do movimento da qualidade. } \\
\text { - Heterogeneidade. }\end{array}$ \\
\hline
\end{tabular}

Fonte: Transcrito de Wood Jr. (1995:233)

As mudanças demonstram o aumento da responsabilidade estratégica e gerencial nos gestores de Recursos Humanos. Gerenciais de recursos humanos têm demonstrado fragilidade nos novos instrumentos, medidas e performance específicas, conforme publicou Toledo (1982:17). 


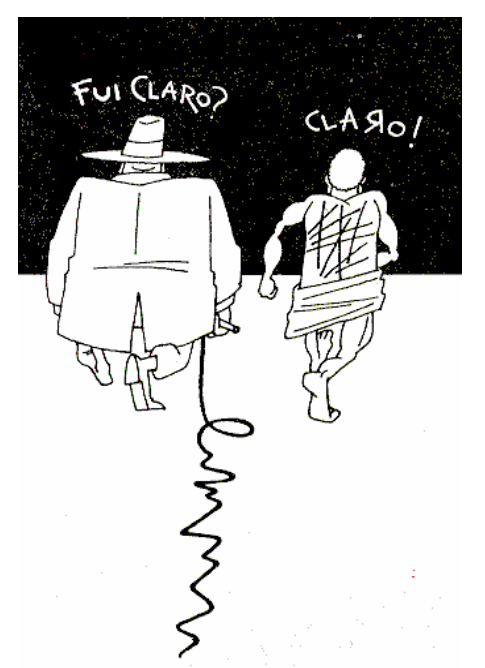

Desenho extraído de O que são Recursos Humanos. Flávio de Toledo, 1982:17.

1.3.5 Ambiente manufatura 
"A manufatura é o elo perdido na estratégia competitiva das empresas" Skinner (1969 in Fleury e Fleury, 1995). Esta afirmação nos remete ao ambiente de trabalho do início do século, que agora está sendo renovado. Nas manufaturas, no ambiente ocupacional tudo está sendo reconstruído: processos, capacitações, responsabilidade, desenho dos processos de produção, novas fronteiras do poder. É uma revolução silenciosa, mas visível: menos postos de trabalho, novas tecnologias, controle e documentação, limpeza e visibilidade associados aos requisitos da qualidade.

Tradicionalmente, a valorização do trabalho e do trabalhador passa pelo domínio do conhecimento ou pela não-necessidade de qualificação, aparecendo a figura do operário ajudante-geral ou semiqualificado. Era clara a distinção entre diriginte-dirigido, onde o primeiro assume o saber e o pensar, e o segundo, o fazer (Motta, 1991).

A qualidade nas empresas vem acompanhada de mudanças na natureza do esforço para o trabalho. Gonçalves (1994:34) relata que "nas fábricas e também nos escritórios, o esforço físico dá lugar a utilização da inteligência e da capacidade do trabalhador alavancadas através de ações educacionais e de treinamento e, principalmente, de um contexto organizacional que privilegia o espaço para crítica conseqüente, o trabalho em grupo e, finalmente, a coresponsabilidade". Não é suficiente apenas fazer, é preciso pensar e sentir. Estamos em transição da manufatura para a cerebrofatura. Schumacher (in 
Cerquinho, 1994) afirma: "O objetivo básico do industrialismo moderno não é tornar gratificante o trabalho, mas aumentar a produtividade." Deste modo, muitas vezes a vida produtiva de um trabalhador torna-se indigna por diversos tipos de alienação por parte do empresário e até por parte do próprio empregado.

Diferenciam-se dois paradigmas nos processos de gestão: a qualificação, que, segundo Hirata (1992), é uma relação social com correlação de forças que distingue postos de trabalho e cargos na estrutura organizacional, obtida a partir da educação formal; e a competência, definida pela mesma autora, como habilidade profissional, relativa à iniciativa, responsabilidade, flexibilidade e envolvimento, apreendida do aprendizado implícito com foco estritamente pessoal.

Para que estas mudanças ocorram, as ações ligadas à administração e ao desenvolvimento de pessoal sustentam-se em novos sistemas e estruturas, visando à redução de níveis hierárquicos, comunicações mais informais, porém mais assertivas, documentação e padronização de procedimentos, participação e co-responsabilidade.

O abandono da função manufatura como parte da inteligência da empresa reforça sua imagem operacional. A manufatura tornou-se uma função burra sem valor, que deveria cumprir determinações emanadas de funções nobres. Hoje, por um passe de mágica, ou ameaça mercadológica, ela deve ser competitiva, inovadora, sem desperdício, defeito zero! É um esforço que exige muita performance. Muita qualidade de vida no trabalho para renascer de valores enterrados na planta da fábrica e "disciplinadamente controlados" por operários 
padronizados e disciplinados a obedecer ordens superiores: "Manda quem pode", “Obedece quem tem juízo”, “Adoece quem é fraco”.

$\mathrm{Na}$ evolução das relações de gestão, está ocorrendo a passagem da valorização da relação social para a valorização do compromisso pessoal, o que modifica toda a lógica da sociologia das qualificações para o trabalho.

Zarifian (in Fleury, s/d.) distingue esta qualificação no contexto da organizacional. Organizações qualificadas, em diferenciação das organizações simplesmente qualificadas, são aquelas em que:

- o trabalho ocorre em equipes ou em células;

- existe autonomia delegada às células e a organização se responsabiliza pelos objetivos de desempenho: qualidade, custos, rendimento etc.;

- há diminuição dos níveis hierárquicos e do desenvolvimento das chefias para atividades de animação e gestão de recursos humanos;

- há reaproximação das relações entre as funções da empresa (entre a manutenção e a fabricação, entre a produção e a área comercial).

A atividade de montagem é, em geral, de grande importância não só em termos de sua presença em diversos setores industriais, como também em número de empregos que gera, em particular no caso brasileiro. Em alguns setores, a automação industrial tem sido utilizada para substituir o trabalho humano nas atividades de montagem (Marx, 1992).

Eboli (1996) citando Touraine, no que se refere ao envolvimento da pessoa em sua situação social e, portanto, também na situação na empresa, fala do 
sujeito, isto é, da construção do indivíduo como ator, é impossível separar o indivíduo de sua situação social. Deve-se, isso sim, ao indivíduo consumidor de normas e de instituições sociais opor o indivíduo produtor dessa vida social e de suas mudanças. É em termos de ator e de conflito social que se deve definir o sujeito: ele não é o princípio que paira acima da sociedade nem o indivíduo em sua particularidade; ele é um modo de construção da experiência social, como o é a racionalidade instrumental.

Lima (1995:23-42) fez detalhada caracterização das políticas de $\mathrm{RH}$. As denominações encontradas são diversas: gerenciamento estratégico participativo, gerenciamento do terceiro tipo, pós-fordismo, gerenciamento da qualidade total. Todas têm o objetivo de absorção máxima das energias e talentos individuais. Para maior clareza estamos a seguir

As principais características das novas políticas de Recursos Humanos são:

- Recompensas econômicas conjugadas com recompensas simbólicas.

- Substituição dos mecanismos clássicos de controle pela confiança.

- Substituição de linguagem: colaboradores, parceiros, portas abertas etc.

- Controle via autodisciplina, pressão, autonomia outorgada, valorização do trabalho.

- Espírito global: empresa algo mais que local de trabalho.

- Oportunidades de promoções horizontais e verticais.

- Estabilidade de emprego.

- Autonomia controlada.

- Competição acentuada no mercado.

- Competição no interior da empresa: duelos de performance.

- Medidas para aumentar fluxo de informações.

- Intelectualização das tarefas.

- Grande exigência de flexibilidade e adaptabilidade.

- Tendência a eliminar o papel autoritário da hierarquia.

- Valorização do consenso, antecipação dos conflitos.

- Política de individualização, visando evitar reivindicações coletivas.

- Controle pela adesão e interiorização de regras.

- Redução drásticas do número de especialistas. 
- Novas formas de gerenciamento científico de pessoas.

- Educação como ênfase à formação profissional.

- Síntese dos modelos japonês (equipe) e americano (esforço individual).

- Existência do outro: visando à impressão de respeito e valorização.

- Exigência de qualidade total - defeito zero - dos produtos e serviços.

- Substituição da programação pela estratégia.

- Priorização dos objetivos financeiros.

Estas características apresentadas pela autora mais como denúncias de manipulação do que como virtuosidades sinalizam o cenário de contradições entre as condições dadas, o sentimento de autonomia, o retorno e as condições construídas. Muitas destas inovações de gestão foram desejadas pelos que trabalham em sistemas produtivos. $O$ que falta para reconhecer a dimensão essencial do compromisso do ser humano em organizações competitivas, que podem pertencer ou não ao seu mundo pessoal ou gerar melhores ou comprometidas condições de vida?

As características de resistência, conforto e alerta ainda não se integraram efetivamente na gestão de recursos humanos. Ela tem grande banco de dados apenas, nos serviços de saúde e segurança do trabalho, que têm tido muita utilidade para demandas fiscais e, casualmente, para ações gerenciais visando a resultados de melhoria organizacional.

Kochan et alii (1995) afirmam que o departamento de recursos humanos devem assumir, juntamente com as lideranças e a alta cúpula da empresa, o papel de influenciar a adoção das práticas de qualidade total. Segundo os autores, em pesquisa internacional observaram-se que os sindicatos influenciam estas práticas da qualidade total, mas com conteúdo ideológico diferente da organização. 
Tolovi (1994), em pesquisa sobre as falhas dos programas de qualidade, afirma: "É fundamental que os dirigentes de nossas empresas entendam que os programas de qualidade são programas que tratam do comportamento das pessoas e, portanto, leva tempo."

Causas

educacionais

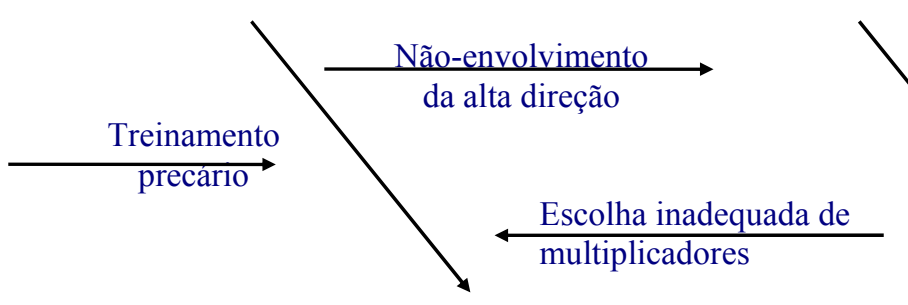

Falta de apoio

técnico

inconsistente

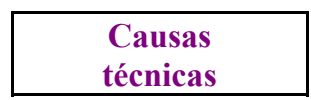

Causas

psicossociais

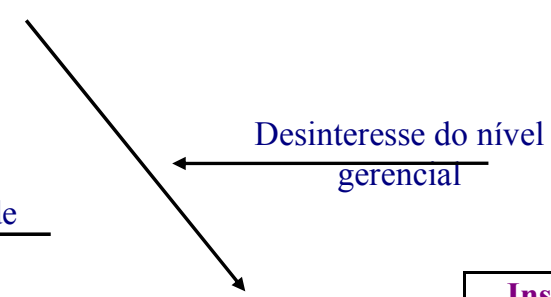

Insucesso dos programas de qualidade

Fonte: Revista de Administração de Empresas, v. 34, nº 6, p. 9, nov/dez, 1994.

Figura. 1.9 Diagrama de Causa e Efeito de Insucesso dos Programas de Qualidade.

A produtividade e a gestão dos recursos humanos condicionam modos, trocas e interinfluências das relações de produção. $O$ resultado deste esforço gera, em conjunto, o produto, que difere em qualidade, dependendo das condições gerenciais, tecnológicas, sociotécnicas e humanas.

$\mathrm{Na}$ contextualização dos programas de qualidade, a construção do sentido social compartilhado decorre da necessidade coletiva de competir, para tornar-se eficaz e assim perpetuar a empresa e o compromisso com o trabalho competente. 
Sendo o "poder uma prática social que assume práticas heterogêneas, às vezes, díspares entre si" (Fischer 1989), quando da implantação de mudanças, as redes de poder estão presentes. O desafio é perceber o efetivo jogo de forças que se estabelece diante deste, ora inovador, ora mantendo do fato organizacional.

Os impactos e as mudanças da cultura das empresas diante dos processos de gestão da qualidade partem do pressuposto de que a inovação do trabalho e os modos de vida organizacional estejam intrinsecamente associados à gestão de negócios, aos padrões de produtividade, ao estilo e à maturidade da cultura de cada empresa.

A atitude para a qualidade modifica o conceito de ineficiência e, portanto, das redes de poder de mando. O erro não "deve" ser mais visto como ameaça à disciplina, mas como potencial para constante melhoria compartilhada. Os feudos tão comuns nos setores produtivos tradicionais, onde a disciplina é mais valorizada que a própria produtividade, devem transformar-se em núcleos dinâmicos de competência, com estrutura e tempo vulneráveis às demandas de mercado.

$\mathrm{Na}$ gestão da qualidade, os recursos-chaves são custos de pessoal competitivos, delegação de autoridade e responsabilidade, estrutura enxuta e flexível (o que aumentou a incidência das terceirizações e das reduções de níveis hierárquicos), o desenvolvimento de liderança participativa e transformacional, a capacitação e a motivação intrínseca.

Fleury et alii (1992), em pesquisa realizada em empresas brasileiras apontam a capacitação tecnológica como indispensável para a disseminação dos 
programas de qualidade e produtividade no Brasil. Este fator é decorrência das dificuldades encontradas pelas empresas brasileiras no acirramento das crises, na sobrecarga gerencial e na inconsistência da alta administração. Estas dificuldades, freqüentemente, geram até um retrocesso nos modelos de relações de trabalho, acentuado pela fraqueza dos movimentos sindicais brasileiros.

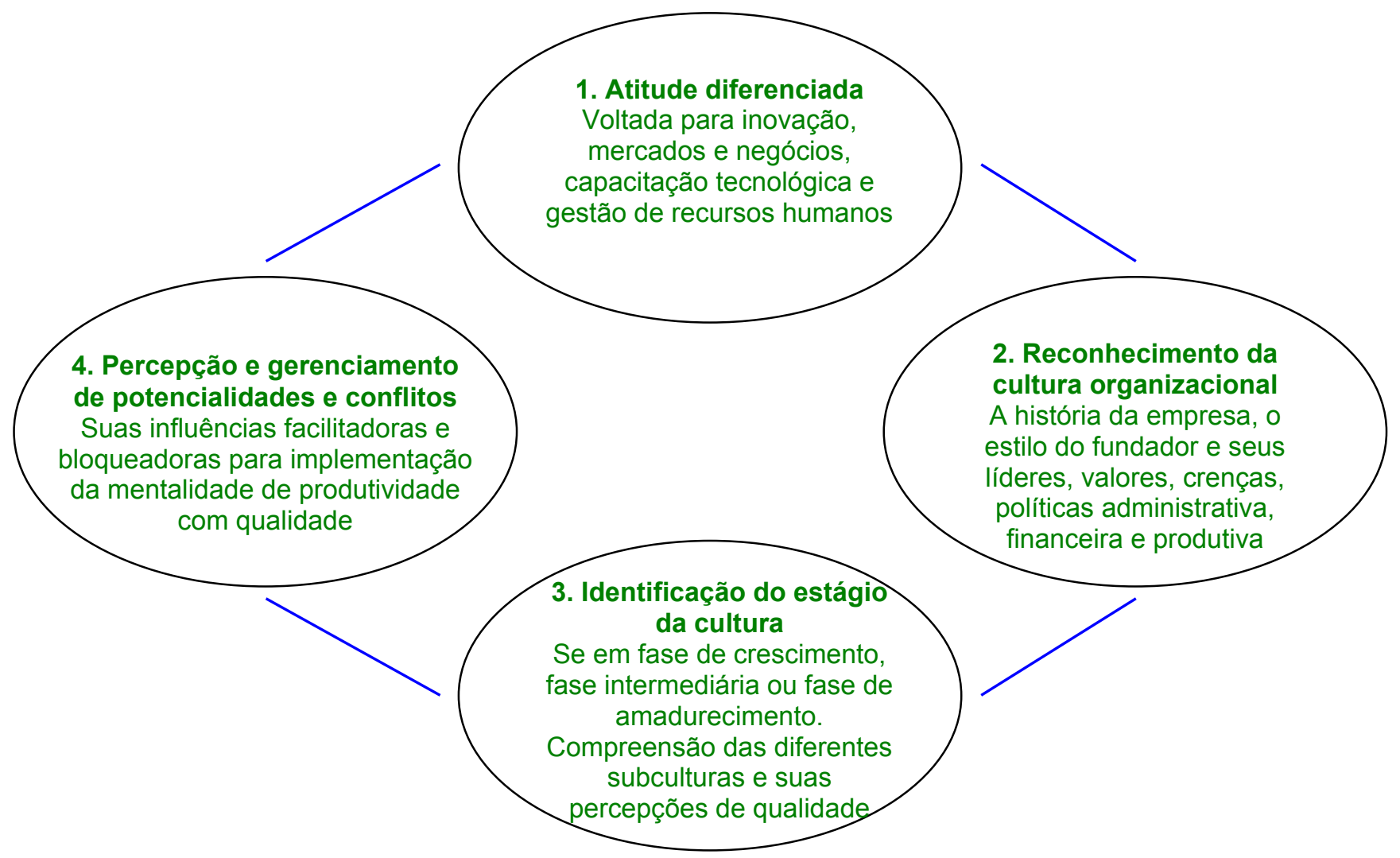

Figura. 1.9 Construção da qualidade nas empresas.

Outros impactos nas relações de gestão da produção encontram-se no deslocamento dos postos de trabalho, como foco central da produção, para os processos de planejamento, onde é enfatizada a liderança não autoritária. Modernização pressupõe mudanças de referenciais hierárquicos - é a supervisão controladora que deve passar a ser uma co-supervisão de conformidade de 
padrões. É a convivência com "dupla chefia, comitês, linha e staff, relações de coordenação, grupos de tarefa, aspectos (estruturas) matriciais e de projetos" (Spink, 1991).

Os mecanismos de resistência diante dos novos conhecimentos, atitudes e vínculos caracterizam subculturas de oposição. Estes mecanismos em programas de qualidade são identificados via "ordem" para participar. Outras vezes surgem processos silenciosos de cooperação, talvez uma subcultura de sobrevivência. É o caso dos operários que necessitam de ajuda técnica fora do expediente, buscando informações fora da empresa e até mesmo com parente próximo para preencher planilhas ou realizar cálculos estatísticos.

Diante de impactos tão específicos que geram respostas geralmente inespecíficas, mas atingindo todos os níveis hierárquicos da organização, Qualidade com Qualidade de Vida no Trabalho parece ser um bom objetivo para gestão de recursos humanos, que vem sendo cada vez mais solicitada para uma atitude mais estratégica e preservadora do potencial humano na organização.

As demandas de gestão aqui analisadas envolvem pessoas de maneira mais marcante neste momento de competitividade. Está ocorrendo uma revolução não muito silenciosa no chão das fábricas. Os conceitos-chaves são: trabalho, disciplina, liderança, produção.

Propositadamente não nos estendemos na questão externa da competitividade e gestão, porque nosso propósito é a questão interna - políticas e gestão internas ao ambiente organizacional. Sewell e Brow (1993) pergunta: quem é mais importante? Seu cliente ou seu funcionário? Resposta: Ambos e devem ser 
tratados igualmente bem. O bom tratamento dos seus funcionários começa com a área de trabalho deles, mas é mais que apenas estética. São melhores equipamentos e ferramentas, áreas individuais e não simplesmente "baias" minúsculas, modo de tratamento e a promoção de atividades informais e festivas.

Para finalizar, citamos Oliveira (1994:56) quanto a mitos e realidades no Brasil. O autor acreditou que apesar de existirem fatos e "reportagens, ainda que fossem algo inflados, não poderiam ser totalmente negados" 


\section{METODOLOGIA}

2.1 NATUREZA E MÉTODO DE ESTUDO 92

$\begin{array}{ll}\text { 2.1.1 Estudo de campo } & 92\end{array}$

2.2 MODELO CONCEITUAL E DESENHO DO PROBLEMA 97

$\begin{array}{ll}\text { 2.2.1 Proposição chave } & 98\end{array}$

2.2.2 Medidas dos Indicadores $\quad 101$

2.3 VARIÁVEIS BIOPSICOSSOCIAIS: DEFINIÇÕES E CRITÉRIOS 103

$\begin{array}{ll}\text { 2.4 FONTES E INSTRUMENTOS DE PESQUISA } & 109\end{array}$

$\begin{array}{ll}\text { 2.4.1 Fontes } & 109\end{array}$

$\begin{array}{ll}\text { 2.4.2 Critérios de amostragem } & 110\end{array}$

2.4.3 Questionários $\quad 112$

2.4.4 Pré-teste $\quad 115$

$\begin{array}{ll}2.4 .5 \text { Reaplicação } & 117\end{array}$

2.5 TÉCNICAS DE ANÁLISES DOS RESULTADOS 118 


\subsection{NATUREZA E MÉTODO DO ESTUDO}

"O conhecimento científico, como a linguagem, é intrinsecamente a propriedade comum de um grupo ou então não é nada."

Thomas S. Kuhn.

Buscando uma metodologia de abordagem específica para ambientes organizacionais, foram localizados estudos significativos na área de comportamento organizacional. Dejours (In Chanlat, 1992) propõe a criação do "espaço coletivo", que é o momento em que em situação de grupo as pessoas compartilham seus valores e sentimentos sobre questões específicas, inclusive do trabalho.

Os estudos brasileiros de Fernandes, E.C. (1994) e Rodrigues M.V.C. (1992) têm utilizado metodologias de coleta de dados com indicadores pré-selecionados. Fernandes utilizou a Auditoria Operacional, em que apurou o grau de satisfação de empregados de 120 empresas. Rodrigues (1994) identificou fatores favoráveis de desempenho e qualidade de vida no trabalho, com base nos critérios de Walton (1975) e Silva (1995) e levantou dados de trabalhadores da construção civil através de análise das condições de trabalho.

A equipe da UFMG, coordenada por Moraes e Kilimik (1994), realizou um levantamento de extenso questionário que coletou a opinião de funcionários públicos sobre o significado pessoal das condições de trabalho. Os dados eram de 
autopercepção em levantamento através de questionários estruturados com escalas variadas, dependendo do foco: trabalho, vida pessoal, satisfação pessoal, ou então mediante técnica de entrevistas não estruturadas ou entrevistas em grupo (Fernandes, 1992:38).

As alternativas metodológicas mais tradicionais são:

1. Exploratória: sua natureza é, essencialmente, "descobrir idéias e intuições" com métodos de pesquisa flexíveis, de modo que permita a consideração de muitos aspectos de um mesmo fenômeno.

2. Descritiva: seu objetivo é apresentar as características de uma situação e verificar a freqüência com que este fenômeno ocorre.

3. Estudos causais: procuram verificar uma hipótese de relação causal entre variáveis, (Katz, In Kerlinger, 1984:406 apud Sbragia (1982) e Mattar (1994).

A opção por um estudo exploratório, mas de natureza correlacional, foi relacionar a opinião pessoal de satisfação aos esforços declarados pela empresa.

A escolha metodológica adotada é, portanto, de relação causal. Trata-se de problema com múltiplas variáveis, investigadas em situação de campo, sem instrumental de controle ou intervenção delas, mas com ênfase na coleta, observação e análise. A relação causal via dados quantitativa em coleta direta de campo é complementada com análise de dados descritivos que têm um caráter qualitativo. 
O objetivo é entender relações, não no sentido restrito de causalidade, mas de prováveis correlações entre as ações gerenciais e a satisfação dos empregados com estas ações.

O estudo da inter-relação dessas variáveis necessita de alguns cuidados para evitar ou pelo menos controlar as possíveis limitações de expressão da subjetividade num contexto coletivo. Coda (1992:49-51) aponta a técnica de questionário como um instrumento válido para avaliar este tipo de variáveis da cultura organizacional. As condições que destaca, com base na citação de Tucker, são:

- ter origem no consciente coletivo;

- atender a padrões de consistência interna, confiabilidade e validade de conceito;

- demonstrar validade discriminante entre os diferentes indicadores adotados;

- ser empiricamente sensível às dimensões lógicas identificadas pelos membros da organização;

- fornecer subsídios para a previsão dos aspectos estudados do comportamento organizacional.

Coda incluiu estas condições para o estudo de Clima e Cultura Organizacional e dada a semelhança dos fatores, acreditamos que sejam válidos para o estudo de qualidade de vida no trabalho. 
Reforçando o significado coletivo apontado, deve-se considerar que o conteúdo destas variáveis que compõem o desenho do problema tem origem nas representações sociais, isto é, na composição do pensamento individual enraizado em determinado contexto social e que gera um produto - um significado pertinente às suas condições de produção coletiva-individual (Spink, M.J, 1993:8990). Assim, variáveis produzidas de percepções individuais podem ser compartilhadas coletivamente.

\subsubsection{Estudo de Campo}

O estudo de campo, segundo classificação de Katz (In Kerlinger, 1963: 406), parece pertinente para este tipo de problema, uma vez que se trata de um fenômeno pouco explorado, cujas variáveis não estão claramente consolidadas em termos conceituais.

Foram tomados os seguintes cuidados metodológicos:

- limitar, após a definição dos indicadores e mapeamento conceitual, a escolha das variáveis a serem pesquisadas;

- não estabelecer relações causais diretas, mas possíveis tendências correlacionais, que podem estar permeadas de processos e variáveis não identificados ou intangíveis. 
Para melhor compreensão do método destacam-se no Quadro 2.1 as potencialidades e limitações que estão sendo avaliadas na opção da metodologia de pesquisa.

Quadro 2.1 Pesquisa de campo: potencialidades e fraquezas.

\begin{tabular}{l|l}
\hline \multicolumn{1}{c|}{ Potencialidades } & \multicolumn{1}{c}{ Fraquezas } \\
\hline Realismo e significância prática. & Fragilidade das relações entre variáveis. \\
\hline $\begin{array}{l}\text { Flexibilidade para a consideração de } \\
\text { hipóteses alternativas. }\end{array}$ & $\begin{array}{l}\text { Mensurações menos precisas que as obtidas } \\
\text { em métodos experimentais. }\end{array}$ \\
\hline $\begin{array}{l}\text { Proximidade dos fenômenos sociais e e } \\
\text { organizacionais em processo (on going }\end{array}$ & $\begin{array}{l}\text { Redução da profundidade das mensurações } \\
\text { events). }\end{array}$ \\
$\begin{array}{l}\text { Levantamento de informações e proposições } \\
\text { que podem e tempo. }\end{array}$ & $\begin{array}{l}\text { Dependência da cooperação das pessoas } \\
\text { que são fonte das informações. }\end{array}$ \\
experimentais.
\end{tabular}

Fonte: Adaptado de SBRAGIA, R. O impacto de aspectos ligados à operação de estruturas matriciais sobre o desempenho de projetos de P\&D. Tese de Doutorado. São Paulo : FEA/SP, 1982. p. 101-102. 


\subsection{MODELO CONCEITUAL E DESENHO DO PROBLEMA}

O modelo conceitual de Rubenstein (1976), Delineamento de Problemas Organizacionais Complexos, tem como idéia central construir o desenho do problema a ser pesquisado. Os elementos que compõem o desenho estão detalhados e definidos no Quadro 2. 2 a seguir:

Quadro 2.2 Elementos que compõem o MDPO.

\begin{tabular}{|c|l|}
\hline Elemento & \multicolumn{1}{|c|}{ Definição } \\
\hline Paradigma & Modelo de estruturação de problemas num campo particular. \\
\hline Critérios & Elementos definidos a partir dos objetivos, valores e conceitos adotados. \\
\hline Proposições & Evidências de obtenção dos resultados ou critérios. \\
\hline Variáveis & Proposições de grande impacto selecionadas para manipulação do fenômeno. \\
\hline Parâmetros & $\begin{array}{l}\text { Condições dadas a respeito do fenômeno e não passível de manipulação no } \\
\text { paradigma delineado. }\end{array}$ \\
\hline
\end{tabular}

Fonte: Adaptado de RUBENSTEIN, A.H. An approach to organizational design. San Francisco : Jossey Bass, 1986. p. 1-5. 
As empresas apresentam variações de esforço nos programas e ações de Qualidade de Vida no Trabalho, que estão relacionados à variação da satisfação de seus empregados. A Figura 2.1 mostra o desenho do problema a ser investigado.

Esta proposição leva à hipótese de que existem relações entre esforço das empresas e satisfação dos empregados conforme demonstrado na Figura 2.1.

Esta proposição leva a indagações específicas, relativas a:

- satisfação dos empregados, suas características e significados variados nos diversos níveis hierárquicos;

- elementos e grau de organização do esforço das empresas nos programas e ações de Qualidade de Vida no Trabalho;

- situações em que o esforço é visto como ferramenta gerencial;

- associação de requisitos ISO 9000 ao esforço da empresa para ações de qualidade de vida. 


\begin{tabular}{|c|c|}
\hline \multicolumn{2}{|c|}{ ESFORÇO DA EMPRESA } \\
\hline ORGANIZACIONAIS & PSICOLÓGICAS \\
\hline $\begin{array}{l}\text { - Endomarketing } \\
\text { - Programa T\&D } \\
\text { - Implantação de processos e tecnologias } \\
\text { - Gestão participativa } \\
\text { - Redução de burocracia } \\
\text { - Atendimento às rotinas de pessoal }\end{array}$ & $\begin{array}{l}\text { - Critérios de recrutamento e seleção } \\
\text { - Ferramentas de avaliação de desempenho } \\
\text { - Gestão do clima organizacional } \\
\text { - Plano de carreira } \\
\text { - Administração de salários } \\
\text { - Respeito à vida pessoal }\end{array}$ \\
\hline BIOLÓGICAS & SOCIAIS \\
\hline $\begin{array}{l}\text { - Semana de prevenção de acidentes } \\
\text { - Prevenção de riscos - PPRA } \\
\text { - Ambulatório / convênio médico } \\
\text { - Ginástica / refeições } \\
\text { - Controle médico - PCSMO } \\
\text { - Atuação da CIPA }\end{array}$ & $\begin{array}{l}\text { - Convênios comerciais } \\
\text { - Atividades de lazer } \\
\text { - Atendimento aos filhos } \\
\text { - Fornecimento de cesta básica } \\
\text { - Previdência privada } \\
\text { - Financiamento de cursos externos }\end{array}$ \\
\hline \multicolumn{2}{|c|}{ Variáveis independentes } \\
\hline & $\begin{array}{l}\text { Parâmetros } \\
\text { - Perfil sociofuncional } \\
\text { - Perfil dos empregados } \\
\text { - Ramo de atividade } \\
\text { - Estágio da gestão de QVT }\end{array}$ \\
\hline \multicolumn{2}{|c|}{ Variáveis dependentes } \\
\hline ORGANIZACIONAIS & PSICOLÓGICAS \\
\hline $\begin{array}{l}\text { - Imagem da empresa } \\
\text { - Oportunidades de T \& D } \\
\text { - Melhorias nos processos e tecnologias } \\
\text { - Participação em comitês } \\
\text { - Qualidade dos processos administrativos } \\
\text { - Atendimento a registro, férias, pagamento, etc }\end{array}$ & $\begin{array}{l}\text { - Confiança no recrutamento e seleção } \\
\text { - Formas de avaliação de desempenho } \\
\text { - Clima de camaradagem } \\
\text { - Oportunidade de carreira } \\
\text { - Satisfação com salário } \\
\text { - Ausência de interferência na vida pessoal }\end{array}$ \\
\hline BIOLÓGICAS & SOCIAIS \\
\hline $\begin{array}{l}\text { - Qualidade das SIPAT's } \\
\text { - Controle de riscos ergonômicos e ambientais } \\
\text { - Atendimento no ambulatório / convênio médico } \\
\text { - Oportunidade de realizar ginástica } \\
\text { - Qualidade das refeições } \\
\text { - Estado de saúde dos colegas e superiores } \\
\text { - Atuação da'CIPA }\end{array}$ & $\begin{array}{l}\text { - Qualidade dos convênios comerciais } \\
\text { - Oportunidade de distração } \\
\text { - Atendimento aos filhos (creche, escola) } \\
\text { - Qualidade da cesta básica } \\
\text { - Qualidade dos seguros de previdência privada } \\
\text { - Financiamento de cursos externos }\end{array}$ \\
\hline SATISFAÇÃO D & EMPREGADOS \\
\hline
\end{tabular}

Figura 2. 1 Desenho do problema. 
A partir da revisão bibliográfica citada no item 1.2 do capítulo anterior, chegamos a vários indicadores que alicerçaram a construção dos questionários, quanto aos critérios e respectivos indicadores. São eles:

\section{Lista dos indicadores empresariais de qualidade de vida no trabalho}

- Ação social e ecológica da empresa

- Atividades esportivas, culturais e de lazer

- Ausência de insalubridade

- Ausência de preconceitos

- Autonomia no trabalho

- Capacitação múltipla para o trabalho

- Carreira

- Comprometimento político e estratégico dos empregadores

- Comprometimento político e estratégico dos empregados

- Condições gerais de trabalho

- Conforto do ambiente físico

- Crescimento como pessoa, em função do trabalho

- Direitos legais garantidos

- Distribuição justa de rendimentos entre os cargos

- Educação no relacionamento

- Esperança de continuidade na empresa

- Estabilidade no emprego

- Estima por parte dos colegas

- Imagem da empresa na sociedade

- Imparcialidade nas decisões gerenciais

- Informações sobre o que deve ser feito

- Jornada de trabalho

- Liberdade de expressão

- Nível cultural dos empregadores 
- Nível cultural dos empregados

- Padrão geral de saúde dos empregadores

- Padrão geral de saúde dos empregados

- Privacidade para trabalhar

- Proteção do patrimônio da empresa

- Qualidade da alimentação fornecida pela empresa

- Salário

- Seguro de vida

- Valorização dos serviços pelos outros setores

- Vida pessoal preservada

\subsubsection{Medidas dos indicadores}

Os estudos sobre as medidas dos indicadores têm demonstrado necessidade de cuidados especiais com os significados expressos. Lawler III (In: Davis e Cherns, 1975:123-133) relata as dificuldades de mensurar Qualidade de Vida no Trabalho. Elas referem-se aos problemas de subjetividade, meio ambiente do trabalho, interesses que diferem entre cada grupo. As medidas citadas como objetivas são turn-over, absenteísmo e os índices econômicos utilizados pelos governos. Propõem os seguintes critérios: devem atender a demandas psicológicas, ter autenticidade e envolvimento, permitir verificabilidade e evitar risco de manipulação e observar diferenciação entre respostas individuais no mesmo ambiente de trabalho.

A opção adotada foi por trabalhar estas variáveis com os conceitos de esforço empresarial e satisfação dos empregados. 
O esforço é aqui definido como as atividades, eventos e diagnósticos que são denominados ações e programas desenvolvidos pela empresa.

A satisfação é aqui definida com o mesmo conceito de Edwin Locke adotado por Coda (1990:66): "Satisfação no trabalho é um estado de prazer emocional resultante da avaliação que um profissional faz sobre até que ponto seu trabalho apresenta a capacidade de facilitar ou permitir o atendimento de seus objetivos e valores."

A adaptação deste conceito para o enfoque específico de qualidade de vida no trabalho refere-se às possibilidades de trabalhar com bem-estar, preservação da vida e desenvolvimento humano. 


\subsection{VARIÁVEIS BIOPSICOSSOCIAIS: DEFINIÇÕES E CRITÉRIOS}

Variáveis são, dentro de um conjunto potencial amplo, elementos ou valores característicos de um fato ou conceito a ser estudado, tendo como base a expectativa de serem aspectos de impacto significativo para se manipular a situação proposta. Serão, por definição (Rubenstein, 1980:4), aspectos do fenômeno que podem ser manipulados propositada e diretamente, dentro de determinados parâmetros. São, portanto, quantidades ou condições medidas e controladas que traduzem uma propriedade ou característica observável de um sistema.

Vão ser trabalhados com variáveis independentes e dependentes, agrupadas com base na visão biopsicossocial, da medicina psicossomática, abordada no item 2.4. Com base neste critério temos grupos de variáveis organizacionais, biológicas, psicológicas e sociais, tanto nas variáveis independentes como nas dependentes.

As variáveis foram selecionadas com base nos critérios de Walton, dos indicadores do Índice de Desenvolvimento Social, do Índice de Desenvolvimento Humano e dos estudos de Robert e Wood.

As variáveis independentes foram selecionadas a partir do conceito de Qualidade de Vida no Trabalho em relação às ações da empresas: programas, campanhas, gestão, levantamentos e controle de resultados (ver Quadro 2.3). A definição operacional de esforço é: Avaliação da INTENSIDADE DO ESFORÇO 
GERENCIAL (mobilização organizacional, pessoal e financeira) da Unidade

Certificada - nos últimos 12 meses.

Quadro 2.3 Variáveis independentes: ações específicas da empresa.

\begin{tabular}{|c|c|c|c|}
\hline $\begin{array}{c}\text { Área de } \\
\text { investigação }\end{array}$ & Descrição & $\begin{array}{l}\text { Programas } \\
\text { específicos } \\
\text { indicadores }\end{array}$ & $\begin{array}{l}\text { Setores que } \\
\text { desenvolvem }\end{array}$ \\
\hline Organizacional & $\begin{array}{l}\text { Ações que valorizem a } \\
\text { imagem, estrutura, } \\
\text { produto e } \\
\text { relacionamento da } \\
\text { empresa com os } \\
\text { empregados. } \\
\end{array}$ & $\begin{array}{l}\text { - Endomarketing } \\
\text { - Comitês executivos e } \\
\text { decisoriais } \\
\text { - Comunicação interna } \\
\text { - Imagem externa }\end{array}$ & $\begin{array}{l}\text { - Diretorias executivas } \\
\text { - Marketing } \\
\text { - Recursos Humanos }\end{array}$ \\
\hline Social & $\begin{array}{l}\text { Ações que ofereçam } \\
\text { benefícios sociais } \\
\text { obrigatórios e } \\
\text { espontâneos e criem } \\
\text { oportunidade de lazer e } \\
\text { cultura. }\end{array}$ & $\begin{array}{l}\text { - Direitos legais } \\
\text { - Atividades } \\
\text { associativas e } \\
\text { esportivas } \\
\text { - Eventos de turismo e } \\
\text { cultura } \\
\text { - Atendimento à família }\end{array}$ & $\begin{array}{l}\text { - Serviço Social } \\
\text { - Grêmio Esportivo } \\
\text { - Fundações } \\
\text { especificas } \\
\text { - Recursos Humanos }\end{array}$ \\
\hline Psicológica & $\begin{array}{l}\text { Ações que promovam a } \\
\text { auto-estima e o } \\
\text { desenvolvimento de } \\
\text { capacidades pessoais e } \\
\text { profissionais. }\end{array}$ & $\begin{array}{l}\text { - Processos de seleção } \\
\text { e avaliação de } \\
\text { desempenho } \\
\text { - Carreira } \\
\text { - Remuneração } \\
\text { - Programas } \\
\text { participativos }\end{array}$ & $\begin{array}{l}\text { - Recrutamento e } \\
\text { Seleção } \\
\text { - Treinamento de } \\
\text { Pessoal } \\
\text { - Cargos e Salários } \\
\text { - Relações Industriais } \\
\text { elou Recursos } \\
\text { Humanos } \\
\end{array}$ \\
\hline Biológica & $\begin{array}{l}\text { Ações que promovam a } \\
\text { saúde, que controlem } \\
\text { os riscos ambientais e } \\
\text { atendam às } \\
\text { necessidades físicas. }\end{array}$ & $\begin{array}{l}\text { - Mapa de riscos } \\
\text { - SIPAT } \\
\text { - Refeições } \\
\text { - Serviço Médico - } \\
\text { interno e contratado } \\
\text { - Melhorias } \\
\text { ergonômicas } \\
\text { - Treinamentos } \\
\text { específicos }\end{array}$ & $\begin{array}{l}\text { - Segurança do } \\
\text { Trabalho e Medicina } \\
\text { Ocupacional } \\
\text { - Ambulatório } \\
\text { - Nutrição } \\
\text { - Relações Industriais } \\
\text { elou Recursos } \\
\text { Humanos }\end{array}$ \\
\hline
\end{tabular}


Este conjunto de variáveis foi construído a partir da lista citada anteriormente. Todas se referem a atividades que as empresas já realizam com maior ou menor esforço, conforme pode ser vista no Quadro 2.4.

Os focos das variáveis dependentes e independentes são idênticos. O que modifica é o processo: a variável independente é a gestão da empresa, a variável dependente é a necessidade dos empregados.

As variáveis dependentes referem-se ao grau de satisfação dos "clientes internos" quanto à capacidade de uma gestão compatível com as necessidades organizacionais voltadas para a performance de bem-estar dos empregados, empregados ou colaboradores.

Satisfação: Grau DE SATISFAÇÃo DOS EMPREGADOS COM relação aos programas e ações de qualidade de vida no trabalho realizados pela empresa. 
Quadro 2.4 Variáveis dependentes: grau de satisfação dos empregados.

\begin{tabular}{|c|c|c|c|}
\hline $\begin{array}{c}\text { Área de } \\
\text { investigação }\end{array}$ & Descrição & Indicador específico & $\begin{array}{l}\text { Quem } \\
\text { utiliza }\end{array}$ \\
\hline Organizacional & $\begin{array}{l}\text { Satisfação percebida com } \\
\text { relação à política } \\
\text { organizacional: o que a } \\
\text { empresa faz e reflete no } \\
\text { funcionário. }\end{array}$ & $\begin{array}{l}\text { - Imagem da empresa } \\
\text { - Valorização do produto } \\
\text { - Qualidade das } \\
\text { informações geradas para } \\
\text { comunicação interna }\end{array}$ & $\begin{array}{l}\text { níveis: } \\
\text { direção } \\
\text { gerência } \\
\text { operação }\end{array}$ \\
\hline Social & $\begin{array}{l}\text { Satisfação percebida quanto } \\
\text { ao suporte social de } \\
\text { benefícios legais e } \\
\text { espontâneos }\end{array}$ & $\begin{array}{l}\text { - Envolvimento da família } \\
\text { - Assistência à educação } \\
\text { formal } \\
\text { - Realização de esportes }\end{array}$ & idem \\
\hline Psicológica & $\begin{array}{l}\text { Satisfação percebida quanto } \\
\text { ao atendimento das } \\
\text { necessidades individuais de } \\
\text { reconhecimento, auto-estima } \\
\text { e desenvolvimento. }\end{array}$ & $\begin{array}{l}\text { - Critérios de } \\
\text { recrutamento/seleção } \\
\text { - Avaliação de } \\
\text { desempenho/carreira } \\
\text { - Camaradagem } \\
\text { - Vida pessoal preservada }\end{array}$ & idem \\
\hline Biológica & $\begin{array}{l}\text { Satisfação percebida quanto } \\
\text { aos programas e serviços } \\
\text { que garantam bem-estar } \\
\text { físico ou recuperação de } \\
\text { doenças e manifestações } \\
\text { clínicas. }\end{array}$ & $\begin{array}{l}\text { - Índices de acidente de } \\
\text { trabalho } \\
\text { - Conscientização, saúde e } \\
\text { segurança } \\
\text { - Conforto } \\
\text { físico/insalubridade } \\
\text { - Alimentação }\end{array}$ & idem \\
\hline
\end{tabular}

As variáveis dependentes são complementares, uma a uma, a cada variável independente do mesmo foco. A medida dessas variáveis está no grau de necessidade pessoal para cada fator. 
Quadro 2.5 Variáveis qualitativas sobre o conceito de qualidade de vida no trabalho.

\begin{tabular}{|c|c|c|c|}
\hline $\begin{array}{c}\text { Área de } \\
\text { investigação }\end{array}$ & Significado de QVT & Melhorias & Dificuldades \\
\hline Biológica & $\begin{array}{l}\text { - Saúde } \\
\text { - Segurança } \\
\text { - Ausência de } \\
\quad \text { acidentes }\end{array}$ & $\begin{array}{l}\text { - Sistema de } \\
\text { alimentação } \\
\text { - Ginástica laboral } \\
\text { - Controle de doenças }\end{array}$ & $\begin{array}{l}\text { - Existência de tarefas } \\
\text { perigosas } \\
\text { - Ausência por licenças } \\
\text { médicas } \\
\text { - Necessidade de } \\
\text { alimentação e } \\
\text { repouso } \\
\end{array}$ \\
\hline Psicológica & $\begin{array}{l}\text { - Amor } \\
\text { - Paz } \\
\text { - Realização pessoal }\end{array}$ & $\begin{array}{l}\text { - Valorização do } \\
\text { funcionário } \\
\text { - Desafios } \\
\text { - Sistemas de } \\
\text { participação }\end{array}$ & $\begin{array}{l}\text { - Cobrança excessiva } \\
\text { de resultados } \\
\text { - Relacionamento entre } \\
\text { os empregados } \\
\text { - Falta de motivação e } \\
\text { interesse }\end{array}$ \\
\hline Social & $\begin{array}{l}\text { - Confiança } \\
\text { - Amizade } \\
\text { - Responsabilidade }\end{array}$ & $\begin{array}{l}\text { - Educação para o } \\
\text { trabalho } \\
\text { - Benefícios familiares } \\
\text { - Atividades culturais e } \\
\text { esportivas }\end{array}$ & $\begin{array}{l}\text { - Falta de qualificação } \\
\text { de profissionais } \\
\text { - Condições culturais e } \\
\text { econômicas dos } \\
\text { empregados } \\
\text { - Problemas familiares } \\
\text { dos empregados }\end{array}$ \\
\hline Organizacional & $\begin{array}{l}\text { - Investimento } \\
\text { - Humanismo } \\
\text { - Competitividade }\end{array}$ & $\begin{array}{l}\text { - Clareza nos } \\
\text { procedimentos } \\
\text { - Organização geral } \\
\text { - Contato com o cliente }\end{array}$ & $\begin{array}{l}\text { - Processos de } \\
\text { produção/tecnologia } \\
\text { - Pressão dos clientes } \\
\text { - Preparo da } \\
\text { documentação }\end{array}$ \\
\hline
\end{tabular}

As variáveis qualitativas acima elencadas foram redistribuídas de forma, a garantir respostas não conduzidas. Por exemplo: a palavra saúde é o termo mais comum para qualidade de vida e não foi colocada como primeira da lista de alternativas de palavras-chave (ver anexo a e b). A intenção foi ratificar o significado para QVT, para compará-lo ao comportamento das variáveis. 
Quadro 2.6 Variáveis qualitativas sobre o estado de saúde e tensão.

\begin{tabular}{|l|l|}
\hline \multicolumn{1}{|c|}{ Aspecto selecionado } & \multicolumn{1}{c|}{ Objetivo } \\
\hline Sensação de bem-estar no trabalho & $\begin{array}{l}\text { Autopercepção de ameaças no ambiente de } \\
\text { trabalho. }\end{array}$ \\
\hline Estado geral de tensão (stress) pessoal & $\begin{array}{l}\text { Autopercepção sobre atitude de defesa ou } \\
\text { ameaça. }\end{array}$ \\
\hline Grau de satisfação com sua Qualidade de Vida & Exigência atual com sua qualidade de vida. \\
\hline Adequação das Ações de QVT de sua empresa & $\begin{array}{l}\text { Satisfação com a pertinência das ações da } \\
\text { empresa. }\end{array}$ \\
\hline $\begin{array}{l}\text { Importância da QVT para o resultado de seu } \\
\text { trabalho }\end{array}$ & $\begin{array}{l}\text { Valorização da qualidade de vida para a } \\
\text { produtividade. }\end{array}$ \\
\hline
\end{tabular}

Este conjunto de variáveis de autopercepção deve medir a carência de bemestar, o nível de tensão e as expectativas pessoais de QVT.

Queremos medir o grau de exigência de qualidade de vida do ponto de vista pessoal. Estes dados devem ser complementados com as ocorrências de saúdedoença. Essas ocorrências complementam os dados de QVT do ponto de vista médico e social. 


\subsection{FONTES E INSTRUMENTOS DE PESQUISA}

\subsubsection{Fontes}

Foram utilizados como fontes, de acordo com os critérios de Mattar (1994), dados primários junto aos empregados e secundários: levantamentos estatísticos sobre número, distribuição de empresas certificadas no Brasil e respectivo setor produtivo.

Também foram utilizados como fonte os registros dos Programas de Qualidade, os relatórios de Administração de Recursos Humanos, especialmente nos dados referentes ao perfil da mão-de-obra, movimentação no ambulatório médico, levantamento de necessidades de treinamento, intensidade de treinamento e/ou qualificação profissional adquirida na empresa, grau de escolaridade, carreira, número de postos ocupados e tempo de permanência na empresa e outros que tiverem como objetivo diagnóstico de desenvolvimento organizacional. Estes dados esclarecem os parâmetros em que as variáveis são investigadas.

As técnicas da fase de construção dos procedimentos de coleta de dados dos empregados foram:

- entrevista com especialistas, com questionário semi-estruturado (classificação de Mattar, 1994: 65-66).

- sondagem junto ao universo para definição do tipo de amostragem 
- consulta documental;

- levantamento, via telefone, do número de empregados, produto certificado, instituição certificadora;

- definição e contato com as empresas certificadas, dentro dos requisitos acima descritos.

\subsubsection{Critérios de amostragem}

A amostra foi dividida em dois estágios: as empresas e os empregados. Os critérios de seleção das empresas foram:

- médio porte;

- certificadas com a ISO 9000 até outubro de 1995;

- manufatura;

- localização na região de São Paulo;

- sorteio dentro do universo mapeado.

Os critérios de seleção dos empregados foram:

- segmentação por nível hierárquico;

- sorteio com o total de empregados de planta. 
Mapeado o universo, foram obtidos os seguintes dados, antes de decidir sobre o critério de escolha da amostra: havia 850 unidades na região de São Paulo certificadas até outubro de 1995.

O critério de porte da empresa foi fornecido pela Federação das Indústrias do Estado de São Paulo (FIESP) e determinado pelo número de empregados por planta, a saber:

- micro: 0 a 9 empregados;

- pequena - até 99 empregados;

- média - 100 a 499 empregados;

- grande - mais de 500 empregados.

O critério de ramo do setor produtivo utilizado foi o Código Internacional de Setores Produtivos, que é o mesmo adotado pela Associação Nacional de Pesquisa e Desenvolvimento das Empresas Industriais - ANPEI.

As cidades da região de São Paulo foram: Capital, Santo André, São Bernardo do Campo, São Caetano do Sul, Diadema e Osasco.

A estrutura de Gestão da Qualidade de Vida no Trabalho foi caracterizado pelo número de empregados diretamente ligados aos programas, posição na estrutura organizacional e número anual de programas desenvolvidos.

Quanto aos empregados (sorteio por números aleatórios), foram caracterizados do ponto de vista sociofuncional: idade, cargo, nível hierárquico, faixa salarial número de dependentes, escolaridade e sindicalização.

A variável Estado geral de $\underline{\text { stress }}$ do respondente (com relação a autopercepção e sinais clínicos) também foi pesquisada, pois é sabido que as 
empresas passam por grande tensão de stress, durante o processo de certificação e recertificação.

\subsubsection{Questionários}

Os questionários foram a fonte primária de dados. A elaboração do questionário objetivou especificamente:

- avaliar o grau de satisfação dos empregados e o esforço da empresa em ações e programas de Qualidade de Vida no Trabalho, promovidos pela empresa;

- identificar as melhorias e obstáculos sobre a qualidade de vida durante e após a certificação;

- conhecer o nível de Qualidade de Vida no Trabalho em que as empresas se encontram;

- analisar algumas implicações para a produtividade e recertificação da empresa.

Para composição da pesquisa, foram necessários de dois tipos interdependentes de dados. O primeiro conjunto de dados deveria ter uma fonte que informa sobre esforços e características de gestão da Qualidade de Vida no Trabalho. 
A melhor fonte era o gerente de recursos humanos ou quem dentro da empresa exercesse esta função em nível estratégico e decisorial e não apenas operacional.

As informações foram coletadas de dois tipos de questionários de autopreenchimento. Todos os questionários foram acompanhados de carta detalhada com o objetivo da pesquisa e telefones para informações. Este documento foi assinado pelo orientador e pela pesquisadora e ficou em poder das pessoas que responderam ao questionário (ver anexo 1a).

- Tipo 1: esforço da empresa: Anexo 1b;

- Tipo 2: satisfação dos empregados: Anexo 1c;

O questionário tipo 1 foi preenchido pelo gerente de recursos humanos, "fornecedor" dos serviços de recursos humanos ou função equivalente: diretor administrativo, supervisor de pessoal, diretor geral etc.

A aplicação do questionário é pessoal, em cada empresa, em reunião prémarcada com os responsáveis pela empresa. Ocorrem em salas de treinamento, refeitório, sala de lazer ou sala de reuniões da diretoria.

O questionário do tipo 2 foi aplicado a 20 empregados de cada empresa sorteada, dos níveis operacionais, gerenciais e da direção.

O questionário de roteiro fechado é composto pelos seguintes tipos de escalas (Gouveia , 1995): 
1. Escala ordinal: notas de 0 a 10 (11 notas), que se refere a julgamento atitudinal. Para o questionário tipo 1: esforço e auto- percepção sobre stress e qualidade de vida.

Exemplo:

LEGENDA:

ESFORÇO MODERADO

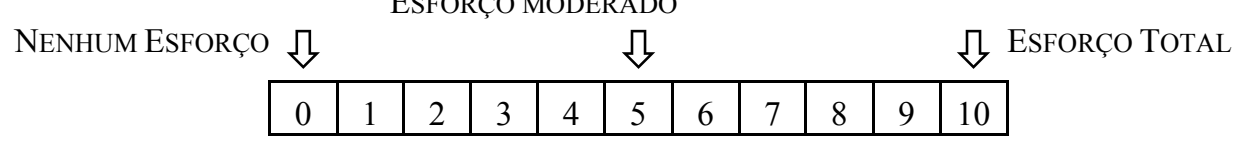

Para o questionário tipo 2: satisfação e autopercepção sobre stress e qualidade de vida.

Exemplo:

LEGENDA:

NEUTRA

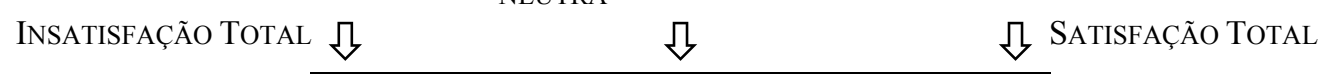

\begin{tabular}{|l|l|l|l|l|l|l|l|l|l|l|}
\hline 0 & 1 & 2 & 3 & 4 & 5 & 6 & 7 & 8 & 9 & 10 \\
\hline
\end{tabular}

O uso da escala de 0 a 10 tem o objetivo de facilitar a interpretação nos diversos níveis de escolaridade. É uma escala mais familiar à cultura brasileira. Além disso, já tem sido utilizada em exercícios de classe, para indicadores semelhantes, pela pesquisadora.

2. Porcentagem desejada e atingida (tipo escala qualiserv) foi utilizada no questionário tipo 1, para avaliação dos programas permanentes e temporários de Qualidade de Vida no Trabalho, conforme exemplo a seguir:

5.1. Considere neste bloco a porcentagem de empregados que DEVERIAM SER ATINGIDOS E QUE FORAM REALMENTE ATINGIDOS nas ações permanentes ou temporárias de QVT, nos últimos 12 meses, de acordo com a LEGENDA:

\section{LEGENDA:}

$1=0$ a $10 \% \quad 2=11$ a $30 \% \quad 3=31$ a $50 \% \quad 4=51$ a $70 \% \quad 5=71$ a $90 \% \quad 6=91$ a $100 \%$ 
3. Escala ordinal: escolher e colocar por ordem de importância:

3.1. Considerando o processo de certificação da sua UNIDADE, indique por ordem de importância TRÊS MELHORIAS DE QUALIDADE DE VIDA NO TRABALHO que facilitariam a implantação da ISO 9000 (vide a LEGENDA):

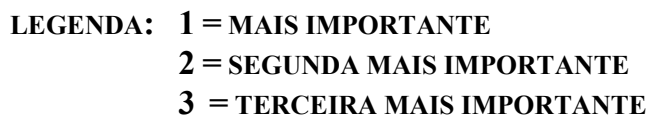

4. Outros tipos de respostas utilizadas nos dois questionários: escalas nominais: SIM/NÃO/NÃO SEI; assinalar eventos que ocorrem; preencher com palavras-chave.

Certos quesitos e atributos poderiam ser vistos com sim/não na escala de 0 a 10, mas a idéia é avaliar a ênfase dada pela empresa e pelo empregado a cada quesito. Trata-se de uma escala nominal.

\subsubsection{Pré-teste}

Após formatação dos questionários, estes foram submetidos a várias condições de aplicações e análise do conteúdo das respostas.

O questionário tipo 1 , que avalia o esforço empresarial para ações e programas de Qualidade de Vida no Trabalho, foi aplicado em 12 profissionais das áreas de recursos humanos, saúde, segurança e engenharia da produção e ergonomia, benefícios, bem como a professores e especialistas em Qualidade de Vida no Trabalho e certificação ISO 9000. 
O questionário tipo 2, que avalia o grau de satisfação dos empregados decorrentes das ações e programas de Qualidade de Vida no Trabalho, foi respondido por 29 empregados de uma manufatura de médio porte da região da Zona Oeste, por 10 empregados de uma montadora em São Bernardo e de uma manufatura de autopeças de Jundiaí. Foi analisado também pelo grupo do questionário tipo 1.

As principais sugestões dos respondentes foram:

- utilizar escala de 0 a 10 e não de 1 a 7, presente nas primeiras versões;

- incluir dados sobre a lucratividade da empresa, nos itens da estrutura organizacional;

- detalhar os outros programas de qualidade para a empresa assinalar;

- incluir o bloco pressões externas no questionário tipo 1;

- incluir aspectos clínicos dos respondentes, para ratificar condições de stress e qualidade de vida;

- aumentar de duas para três escolhas da melhor palavra para qualidade de vida, melhorias e obstáculos na ISO 9000. 


\subsubsection{Reaplicação}

Do universo das 26 empresas sorteadas, duas delas foram revisitadas e reaplicado o questionário.

Através do teste de McNemar, aplicado às questões ocorrências de saúdedoença, em nível de significância de 5\%, não rejeitamos a hipótese de nulidade, ou seja, as alterações não foram significantes.

Para as variáveis medidas pela escala $0-10$ pontos, foi aplicado o teste de Wilcoxon, objetivando concluir sobre a existência de alteração nas respostas. Apesar de haver casos de grandes diferenças, que variam da ausência da ação referente à qualidade de vida no trabalho, na primeira visita, à nota máxima de satisfação na segunda visita (ou vice-versa), não foi constatada diferença nas avaliações entre uma visita e outra. Exceção feita à P126 - Qualidade das refeições oferecidas, em que apenas um funcionário teve a avaliação reduzida.

O fato de os testes não levarem à rejeição da hipótese de nulidade, principalmente no que diz respeito às avaliações dos empregados em relação à empresa, pode ser atribuído à pequena amostra de reaplicação dos questionários.Portanto, os dados obtidos na segunda aplicação indicam de forma bastante limitada alterações não significativas entre a primeira e a segunda aplicações. 


\subsection{TÉCNICAS DE ANÁLISE DOS RESULTADOS}

A análise dos dados tem como escopo a análise exploratória.

As análises estatísticas tiveram os seguintes objetivos:

- Avaliar o grau de satisfação dos empregados em relação ao programa de qualidade de vida desenvolvido pela empresa.

- Avaliar o estágio de gestão Qualidade de Vida no Trabalho em que as empresas se encontram

- Analisar quais ações de recursos humanos são percebidas pelos empregados e como são refletidas.

Os dados desta pesquisa, de acordo com o planejamento amostral, foram obtidos por meio de sorteio, em dois estágios: no universo das empresas e no conglomerado do número dos empregados das empresas sorteadas.

Para o grupo de análise empresas, a seleção foi de um representante da gerência de recursos humanos por empresa, e o dado a ser trabalhado refletirá a opinião dos respondentes em nome da empresa.

Para os empregados, houve sorteio aleatório de 20 empregados por empresa, obedecendo ao critério de estratificação, segundo nível hierárquico. 


\begin{tabular}{ccc}
\hline Nível Hierárquico & Número de sorteados & \% na Estratificação \\
\hline Produção & 14 & $70 \%$ \\
Supervisão & 2 & $10 \%$ \\
Gerência & 2 & $10 \%$ \\
Diretoria & 2 & $10 \%$ \\
\hline
\end{tabular}

Este critério é consistente com a expressiva presença de empresas certificadas no Brasil localizadas no Estado de São Paulo (ver gráfico).

Na unidade primária (de primeiro estágio) as empresas que são sorteadas. Em seguida, do conglomerado sorteado (empresa) sorteiam-se os empregados, de modo que cada um (das áreas envolvidas na pesquisa) tenha a mesma chance de ser selecionado. O detalhamento estatístico sobre a composição da amostra está no Anexo 3.

O sorteio das empresas foi realizado de acordo com o processo sistemático e o sorteio dos empregados de forma aleatória. Através da tabela de números aleatórios e a partir do número de funcionários lotados na unidades, era consultada a lista de pessoal e o gerente de recursos humanos (ou responsável) convocava para a aplicação coletiva em sala predeterminida.

Foram sorteadas também empresas substitutas, que foram contatadas quando a primeira sorteada apresentasse algum impedimento. 
O resultado dos dados obtidos em campo seguirão um critério de aprofundamento crescente na sua explicação. Iniciaremos com a análise exploratória para demonstrar os dados mais expressivos.

A análise exploratória não pretende ser conclusiva. Para Tukey (1977:3) ela favorece a sinalização de eventos que devem ser investigações mais apuradas. A maior contribuição deste tipo de tratamento dos dados é tornar atrativo e interessante um cenário que irá se esclarecer com a continuidade da pesquisa na direção que desperte o rastreamento da investigação estatística.

As técnicas utilizadas estão detalhadas no Quadro 2.7 (ver Sauaia, 1995: 131-137 e Teixeira, 1995:104):

Quadro 2.7 Técnicas estatísticas utilizadas na pesquisa.

\begin{tabular}{|c|c|c|c|}
\hline \multicolumn{4}{|c|}{ Técnicas Univariadas } \\
\hline & Técnica & Amostras & Variáveis \\
\hline Paramétrica & $\begin{array}{ll}\text { análise } & \text { de } \\
\text { variância } & \end{array}$ & Três amostras & $\begin{array}{l}\text { independentes: } \\
\text { conglomerados } \\
\text { dependentes: } \\
\text { escala de } \\
\text { pontos }\end{array}$ \\
\hline \multirow[t]{2}{*}{ Não paramétrica } & $\begin{array}{l}\begin{array}{l}\text { Teste do Qui- } \\
\text { quadrado }\end{array} \\
\end{array}$ & \begin{tabular}{|l} 
Duas amostras \\
independentes
\end{tabular} & nominais \\
\hline & $\begin{array}{l}\text { Teste de McNemar } \\
\text { Teste de Wilcoxon }\end{array}$ & $\begin{array}{l}\text { Duas amostras } \\
\text { relacionadas } \\
\text { Duas amostras } \\
\text { relacionadas }\end{array}$ & $\begin{array}{l}\text { nominais } \\
\text { nominais } \\
\text { escala de } \\
\text { pontos }\end{array}$ \\
\hline
\end{tabular}


(continuação Quadro 2.7)

\begin{tabular}{|c|c|c|}
\hline \multicolumn{3}{|c|}{ Técnicas Multivariadas } \\
\hline \multirow{5}{*}{ Paramétricas } & Técnicas & Variáveis \\
\hline & Análise fatorial & escala de 11 pontos \\
\hline & Análise de conglomerados & escala de 11 pontos \\
\hline & Análise discriminante & $\begin{array}{l}\text { dependentes: grupo de } \\
\text { estrutura da empresa } \\
\text { independente: escala de onze } \\
\text { pontos }\end{array}$ \\
\hline & Análise de regressão & 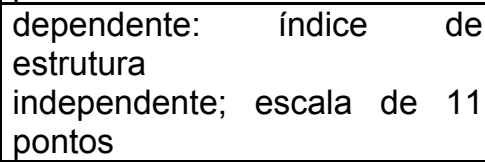 \\
\hline
\end{tabular}

A análise fatorial é uma técnica estatística multivariada, cujo principal objetivo é a redução e sumarização de variáveis.

Análise fatorial expressa a relação entre as variáveis e tenta explicar essas variáveis em seus termos comuns (fatores). Cada variável observada (original) é considerada como variável dependente, isto é, função de fatores hipotéticos.

Pretende-se comparar ainda a relevância de atributos no tocante à qualidade de vida, com o enfoque empresarial versus a visão do funcionário, de maneira que responda se o programa de qualidade atribui a devida importância aos quesitos com maior expectativa, por parte dos empregados.

O Quadro 2.8 apresenta o resumo das características metodológicas da pesquisa. 
Quadro 2.8 Resumo das características metodológicas da pesquisa.

\begin{tabular}{|l|l|}
\hline Natureza do estudo & $\begin{array}{l}\text { Correlacional entre esforço da empresa } \\
\text { e satisfação dos empregados. }\end{array}$ \\
\hline Modelo conceitual & $\begin{array}{l}\text { Delineamento de Problemas } \\
\text { Organizacionais Complexos (MDPO) } \\
\text { (Rubenstein, 1980). }\end{array}$ \\
\hline Instrumento de coleta de dados & $\begin{array}{l}\text { Questionário com afirmações relativas a } \\
\text { indicadores empresariais de Qualidade } \\
\text { de Vida no Trabalho. }\end{array}$ \\
\hline Método de coleta de dados & $\begin{array}{l}\text { Estudo de campo, com aplicação em } \\
\text { grupos de questionário estruturado. }\end{array}$ \\
\hline
\end{tabular}




\section{Análise e Discussão dos Resultados}


3.3.1 Os fatores dos empregados

3.3.1.1 Fator 1: Atuação organizacional

162

3.3.1.2 Fator 2: Necessidades biológicas

164

3.3.1.3 Fator 3: Inclusão social 166

3.3.1.4 Fator4: Prestação de serviço 167

3.3.2 Os fatores da gerência de recursos humanos

3.3.2.1 Fator 1: Imagem da empresa $\quad 170$

3.3.2.2 Fator 2: Saúde e ética 171

3.3.2.3 Fator 3: Desenvolvimento profissional 173

$\begin{array}{ll}\text { 3.3.2.4 Fator 4: Demandas legais } & 174\end{array}$

3.3.2.5 Fator 5: Administração de recursos humanos 175

3.3.2.6 Fator 6: Reposição de energias 176

3.4 ANÁLISE DOS CONGLOMERADOS PARA O SEGMENTO DE EMPREGADOS

3.4.1 Detalhamento dos perfis

183

3.4.2 Aspectos sóciofuncionais

187

$\begin{array}{ll}3.4 .2 .1 \text { Sexo } & 187\end{array}$

$\begin{array}{ll}\text { 3.4.2.2 Nível hierárquico } & 188\end{array}$

$\begin{array}{ll}\text { 3.4.2.3 Faixa salarial } & 189\end{array}$

$\begin{array}{ll}\text { 3.4.2.4 Escolaridade } & 189\end{array}$

3.4.2.5 Número de dependentes 191

3.4.2.6 As variáveis excluídas da análise de conglomerados 191

3.4.2.7 Ocorrência de saúde e doença 193 
3.5 ISO 9000: PRESSÕES, MELHORIAS E OBSTÁCULOS

3.5.1 Pressões externas 197

3.5.2 Melhorias de QVT associadas à certificação ISO 9000 201

3.5.3 Obstáculos de QVT associados à certificação ISO 9000 203

3.5.4 Outros programas de qualidade 205

3.5.5 Ações e programas desejados e atingidos 206

3.5.6 Melhorias percebidas para qualidade de vida no trabalho 210

3.6 ESTRUTURA ORGANIZACIONAL 213 3.6.1 Índice das estruturas 214 3.6.2 Tipos de gestão 218 


\subsection{DESCRIÇÃO}

"A razão muitas vezes está a serviço da paixão. E em função dela cometem-se loucuras perfeitamente justificadas racionalmente."

Eurípedes

\subsubsection{Comportamento da amostra}

Ao determinar os critérios de amostragem, foram escolhidos ambientes ocupacionais homogêneos, freqüentemente envolvidos com a certificação ISO 9000. As manufaturas são ambientes ocupacionais voltados para operações distantes do cliente externo.

O uso de matéria-prima, máquinas, ferramentas e equipamentos fazem das atividades de produção cenários típicos, mesmo nas plantas em que processos de fabricação, em diversos graus de automação e tecnologia, dão a impressão de menor grau de risco ocupacional. Pretendia-se não misturar unidades de manufaturas com as de serviços, objetivando alcançar maior sensibilidade na análise.

O critério localização levou a analista a unidades certificadas da região da grande São Paulo. Embora a maioria delas estivesse muito bem localizada, fosse de fácil acesso e fosse conhecida na região, algumas tinham localização muito distante, o que dificultou a obtenção de informações e a percepção de sinalizações específicas para o acesso. A maioria das plantas era grande, embora 
tivesse entre 100 e 499 funcionários alocados. A grande maioria apresentava bom estado de conservação, mas sem sofisticação ou luxo de empresas de serviços, com exceção dos ambientes de centro empresarial, onde estavam alocadas em prédios distantes da fábrica as diretorias da unidade.

Obtivemos dados de empregados de todos os níveis hierárquicos: direção, gerência e operação. A proporcionalidade de sorteados correspondeu à estrutura de cargos genérica das unidades. Os critérios mostraram-se pertinentes: o grande número das unidades certificadas da grande São Paulo são manufaturas de médio porte. Além disso, São Paulo é o Estado da Federação com significativa presença de Unidades Certificadas, conforme dados da publicação especializada do Comitê de Qualidade: CB n 25 , transcrito no Gráfico 3.1.

Gráfico 3.1 Estados do Brasil com certificação ISO 9000

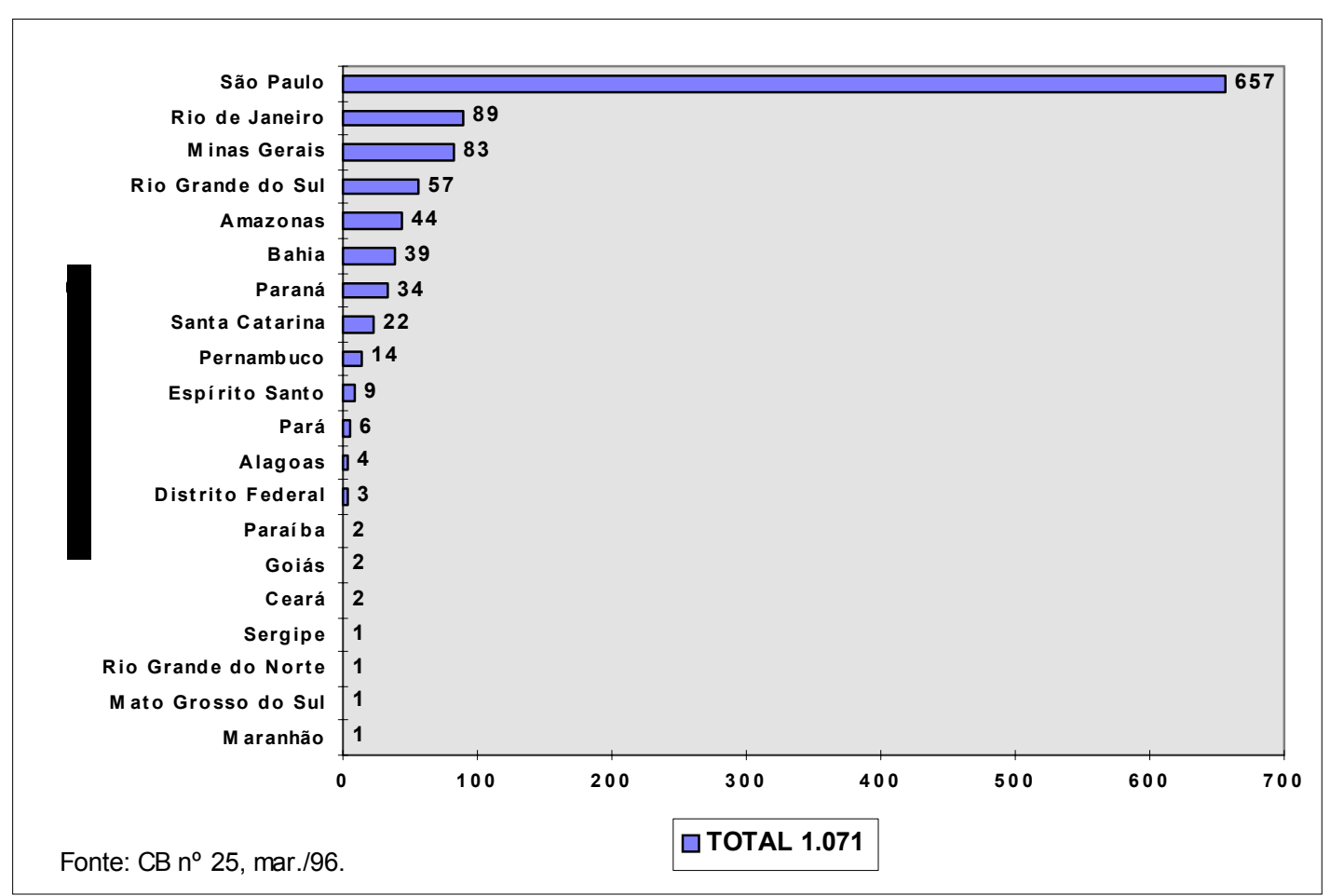


Foram adotados alguns procedimentos para o mapeamento da amostra, com os indícios demonstrados na revisão da literatura de maior concentração do universo pesquisado.

- Foram rastreadas as unidades certificadas nas publicações e relatórios especializados: controle da qualidade: Banas, 1995, Relatórios Fundação Vanzolini, 1995 e ANPEI, 1995.

- Foram selecionadas inicialmente as 204 unidades certificadas na região da grande São Paulo. Em seguida, foram contactadas uma a uma, para conhecer o número atual de empregados da Unidade Certificada, o produto e o tipo de certificação, a localização da planta e o responsável pela gerência de recursos humanos das unidades de negócio certificadas. Nesta fase, a seleção concentrou-se nas das unidades de médio porte da Região de São Paulo certificadas até outubro de 1995, uma vez que representavam a grande maioria das certificadas, conforme Tabela 3.1.

Tabela 3.1 Unidades certificadas da região de São Paulo (até outubro/1995)

\begin{tabular}{|c|c|c|}
\hline Porte & Número & \% no Universo \\
\hline Pequeno & 52 & $26 \%$ \\
\hline Médio & $\mathbf{9 5}$ & $\mathbf{4 6 \%}$ \\
\hline Grande & 55 & $27 \%$ \\
\hline Mais de 1000 empregados & 2 & $1 \%$ \\
\hline Totais & $\mathbf{2 0 4}$ & $\mathbf{1 0 0 \%}$ \\
\hline
\end{tabular}

Fonte: Dados de pesquisa: dez.-fev./95.

Em um universo de 70 unidades certificadas de médio porte, com planta localizada na Grande São Paulo, elas se distribuem em nove ramos de produção, relacionados na Figura 3.1: 


\begin{tabular}{|l|c|}
\hline Setor Produtivo & n . de empresas \\
\hline 1. Componentes eletrônicos e elétricos, exceto computação & 17 \\
\hline 2. Equipamentos de Transporte - Auto-peças & 7 \\
\hline 3. Indústrias de Metal Primário & 3 \\
\hline 4. Instrumentos de Medição & 13 \\
\hline 5. Máquinas industriais e comerciais e equipamentos de computação & 7 \\
\hline 6. Metais, exceto máquinas e equipamentos de transportes & 2 \\
\hline 7. Produtos de Borracha e Plásticos Vários & 2 \\
\hline 8. Produtos de Tecelagem & 12 \\
\hline 9. Químicos e Produtos Químicos & 7 \\
\hline
\end{tabular}


Unidades Certificadas ISO 9000 da Região da Grande São Paulo distribuídas de acordo com a Instituição Certificadora,

certificadas até outubro de 1995

\begin{tabular}{|c|c|c|c|c|c|c|c|c|c|c|c|c|c|c|}
\hline $\begin{array}{l}\text { Instituição Certificadora } \\
\text { Setor Produtivo }\end{array}$ & $\begin{array}{l}A B S / Q \\
E\end{array}$ & BSI & BVQI & $\begin{array}{l}\text { BRTÜ } \\
\text { V }\end{array}$ & DWV & IBQW & $\begin{array}{l}\text { IMMET } \\
\text { RO }\end{array}$ & $\begin{array}{l}\text { LLOYD } \\
\text { 'S }\end{array}$ & RWTV & VANZ & $\begin{array}{l}\text { VANZI } \\
\text { ABS- } \\
\text { QE }\end{array}$ & $\begin{array}{l}\text { VANZI } \\
\text { DQS }\end{array}$ & UCIEE & \\
\hline $\begin{array}{l}\text { 1. Componentes eletrônicos e } \\
\text { elétricos, exceto computação }\end{array}$ & 04 & & 04 & & & 01 & 02 & & & 03 & & 02 & 01 & 17 \\
\hline $\begin{array}{l}\text { 2. Equipamentos de Transporte - Auto- } \\
\text { peças }\end{array}$ & 03 & & 02 & 01 & & & & & & 01 & & & & 7 \\
\hline 3. Indústrias de Metal Primário & 04 & & 03 & & & & & & & & & & & 7 \\
\hline 4. Instrumentos de Medição & 01 & & 01 & & & & & & & & 01 & & & 3 \\
\hline $\begin{array}{l}\text { 5. Máquinas industriais e comerciais e } \\
\text { equip.de computação }\end{array}$ & 02 & & 04 & & 02 & 01 & 02 & & & 02 & & & & 13 \\
\hline $\begin{array}{l}\text { 6. Metais, exceto máquinas e } \\
\text { equipamentos de transportes }\end{array}$ & 05 & & & & & & 01 & 01 & & & & & & 7 \\
\hline $\begin{array}{l}\text { 7. Produtos de Borracha e Plásticos } \\
\text { Vários }\end{array}$ & 01 & & & & & & & 01 & & & & & & 2 \\
\hline 8. Produtos de Tecelagem & & & 01 & & & & & & & & & 01 & & 2 \\
\hline 9. Químicos e Produtos Químicos & 04 & 01 & 02 & & 01 & 01 & & & 01 & & & 02 & & \\
\hline Totais & 24 & 1 & 17 & 01 & 03 & 03 & 05 & 02 & 01 & 06 & 01 & 05 & 01 & 12 \\
\hline
\end{tabular}


A maior concentração das unidades certificadas encontra-se na cidade de São Paulo, e eles são do ramo de atividade de componentes elétricos e eletrônicos. Outro ramo de atividade também concentrado na cidade de São Paulo é o de químicos e produtos químicos.

Quanto à porcentagem de rejeição à pesquisa in loco, o maior número de unidades não pesquisadas, por questões de autorização e disponibilidade das gerência, foi também o ramo de componentes elétricos e eletrônicos. Depois de São Paulo, Santo André é a cidade que apresenta maior número de empresas certificadas, especialmente no setor de químicos e produtos químicos. Nesse segmento, a rejeição à pesquisa foi de apenas uma unidade entre as sorteadas, embora duas das unidades só tenham respondido ao questionário tipo 1 , da gerência de recursos humanos, sobre o esforço da unidade em ações e programas de qualidade de vida no trabalho.

Excetuando-se São Paulo, onde ocorre a grande concentração de unidades, Diadema e São Caetano são as cidades com maior número de certificações, cuja instituição é a $A B S / Q E$. Em termos de números absolutos, há a Instituição BVQI $\left({ }^{*}\right)^{1}$, na cidade de São Paulo.

Localizada a amostra, realizou-se o sorteio das unidades, inclusive com substitutas no caso de problema de realização da pesquisa.

Após a identificação das empresas, realizou-se um novo sorteio para os empregados. O sorteio foi feito segundo a tabela de números aleatórios e os empregados localizados pela ordem da listagem de pessoal. 
Foram pesquisadas, em campo, 26 empresas, após contactar todas as sorteadas, inclusive as substitutas (ver Figura 3.1).

A composição final, após o sorteio no segmento empregados ficou distribuída de acordo com a Tabela 3.2.

Tabela 3.2 Composição dos níveis hierárquicos.

\begin{tabular}{|c|c|c|c|c|}
\hline Empresa & Produção & Supervisão & Gerência & Direção \\
\hline 1 & 14 & 5 & 0 & 1 \\
\hline 2 & 16 & 0 & 3 & 1 \\
\hline 3 & 15 & 2 & 2 & 1 \\
\hline 4 & 14 & 3 & 2 & 1 \\
\hline 5 & 16 & 4 & 0 & 0 \\
\hline 6 & 11 & 4 & 3 & 2 \\
\hline 7 & 10 & 7 & 2 & 1 \\
\hline 9 & 13 & 3 & 2 & 2 \\
\hline 10 & 13 & 2 & 3 & 2 \\
\hline 11 & 15 & 4 & 1 & 0 \\
\hline 12 & 20 & 0 & 0 & 0 \\
\hline 13 & 12 & 5 & 1 & 2 \\
\hline 14 & 13 & 3 & 3 & 1 \\
\hline 16 & 13 & 4 & 1 & 2 \\
\hline 18 & 14 & 2 & 2 & 2 \\
\hline 19 & 12 & 3 & 3 & 2 \\
\hline 20 & 12 & 4 & 3 & 1 \\
\hline 21 & 14 & 4 & 0 & 2 \\
\hline 22 & 14 & 4 & 1 & 1 \\
\hline 24 & 12 & 4 & 3 & 1 \\
\hline 25 & 11 & 4 & 3 & 2 \\
\hline TOTAL & 284 & $\mathbf{7 1}$ & 38 & 27 \\
\hline
\end{tabular}

Para a função gerencial de qualidade de vida no trabalho, a grande maioria dos pesquisados estava lotada na área de recursos humanos e qualidade (onde houve maior receptividade à pesquisa). Significativa percentagem de altos executivos respondeu pela gerência de recursos humanos.

$\left({ }^{*}\right) \mathrm{O}$ nome de cada sigla das Instituições Certificadoras encontra-se no Anexo 6. 
Como previsto no plano de pesquisa, as informações foram coletadas mediante questionários diferenciados, um para a gerência de recursos humanos e outro para as demais áreas, conforme Anexos 1a e 1b.

Houve uma percentagem relevante de rejeições à realização da pesquisa no local da unidade. Os principais motivos foram: algumas unidades haviam mudado da região da grande São Paulo; a planta de outras estava localizada fora da região da grande São Paulo; algumas localizavam-se em outros estados (Betim-MG e Curitiba-PR); uma unidade havia fechado; outra havia terceirizado as atividades da planta da fábrica. As demais não viam possibilidade de coletar dados de seus empregados, em função de demissões, fusões de áreas, cultura da empresa e fase de negociação com sindicatos. Foi contactado um total de 47 empresas, das quais 21 unidades ficaram inviabilizadas.

As dificuldades específicas de autorização para coleta de dados pareciam estar associadas a questões da própria cultura empresarial, ligadas a autonomia dos gerentes de recursos humanos para autorizar a pesquisa dentro das fábricas, sempre dependendo de níveis decisórios superiores ou da área de produção. Sobrecarga de trabalho, freqüência de demissões recentes, crise no setor metalmecânico, especialmente no setor de auto-peças, e suscetibilidade ao tema para alguns tipos de cultura organizacional, especialmente quando coincidiam com futuras demissões, negociações sindicais e fusões de empresas.

A situação final da amostra está detalhada no Gráfico 3.2. Tendo em vista o alto índice de recusas: 17 empresas (39,5\% entre as 43 sorteadas), as mudanças de localização da planta, as fusões de unidades, o crescente número de novas 
unidades certificadas no Brasil (em torno de 1.500 certificações no segundo semestre de 1996), optou-se por analisar e concluir sobre os dados apenas para a amostra pesquisada.

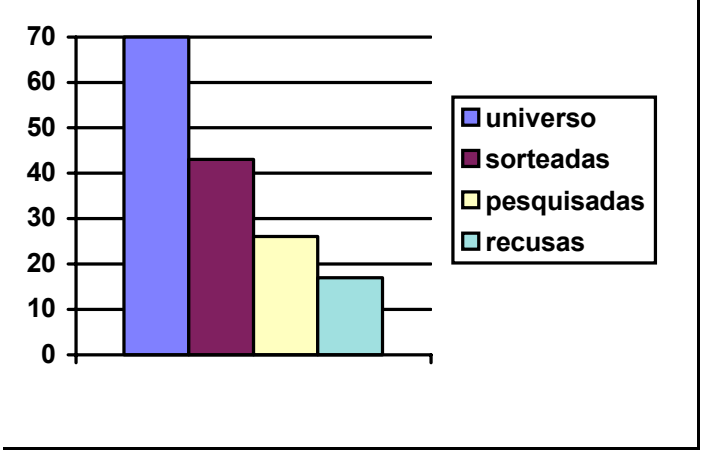

Gráfico 3.2. Histórico da amostra. 


\subsubsection{Caracterização dos segmentos}

\subsubsection{Empregados}

A composição sociofuncional refere-se à faixa etária, sexo, nível hierárquico, faixa salarial, número de dependentes.

\section{a) Faixa etária}

A amostra foi composta por empregados entre 17 e 75 anos. Duas faixas etárias predominaram: 27-36 e 37-46 anos; juntas, elas formaram $67 \%$ da amostra, concentrados especialmente nos níveis de supervisão e gerência. 0 maior número de empregados era do setor de produção $(n=249: 61 \%)$.

Essa faixa etária representara pessoal com maturidade de trabalho. A grande maioria era do sexo masculino $(85 \%)$; e $24 \%$ das mulheres $(n=97)$ encontraramse na produção $(51: 12 \%)$.

Tabela 3.3 Faixa etária.

\begin{tabular}{|c|c|c|c|c|}
\hline $\begin{array}{c}\text { FAIXA } \\
\text { ETÁRIA }\end{array}$ & $\begin{array}{c}\text { PRODUÇÃO } \\
(n=249)\end{array}$ & $\begin{array}{c}\text { SUPERVISÃO } \\
(n=101)\end{array}$ & $\begin{array}{c}\text { GERÊNCIA } \\
(n=34)\end{array}$ & $\begin{array}{c}\text { DIREÇÃO } \\
(n=27)\end{array}$ \\
\hline ATÉ 26 & 26,5 & 7,9 & 2,9 & 0,0 \\
\hline DE 27 A 36 & 39,8 & 37,6 & 26,5 & 11,1 \\
\hline DE 37 A 46 & 22,9 & 37,6 & 52,9 & 55,6 \\
\hline DE 47 A 56 & 9,6 & 16,9 & 11,8 & 29,6 \\
\hline MAIS DE 56 & 1,2 & 0,0 & 5,9 & 3,7 \\
\hline
\end{tabular}




\section{b) Níveis hierárquicos}

O que se observa na Tabela 3.4, em decorrência do critério de estratificação, proporção com a composição funcional usual nas empresas, é que $68 \%$ pertencem à produção. Na empresa 12, de atividade de equipamentos de transporte, os empregados da fábrica não se diferenciaram entre produção ou supervisão. A diferenciação foi via escolaridade e faixa etária.

Tabela 3.4 Empregados por nível hierárquico.

\begin{tabular}{|c|c|c|c|c|}
\hline Empresa & Produção & Supervisão & Gerência & Direção \\
\hline 1 & 14 & 5 & 0 & 1 \\
\hline 2 & 16 & 0 & 3 & 1 \\
\hline 3 & 15 & 2 & 2 & 1 \\
\hline 4 & 14 & 3 & 2 & 1 \\
\hline 5 & 16 & 4 & 0 & 0 \\
\hline 6 & 11 & 4 & 3 & 2 \\
\hline 7 & 10 & 7 & 2 & 1 \\
\hline 9 & 13 & 3 & 2 & 2 \\
\hline 10 & 13 & 2 & 3 & 2 \\
\hline 11 & 15 & 4 & 1 & 0 \\
\hline 12 & 20 & 0 & 0 & 0 \\
\hline 13 & 12 & 5 & 1 & 2 \\
\hline 14 & 13 & 3 & 3 & 1 \\
\hline 16 & 13 & 4 & 1 & 2 \\
\hline 18 & 14 & 2 & 2 & 2 \\
\hline 19 & 12 & 3 & 3 & 2 \\
\hline 20 & 12 & 4 & 3 & 1 \\
\hline 21 & 14 & 4 & 0 & 2 \\
\hline 22 & 14 & 4 & 1 & 1 \\
\hline 24 & 12 & 4 & 3 & 1 \\
\hline 25 & 11 & 4 & 3 & 2 \\
\hline TOTAL & 284 & 71 & 38 & 27 \\
\hline
\end{tabular}

c) Dependentes 
A composição característica dos empregados é de um a três dependentes (므 $=234: 56 \%)$, sendo que uma parcela importante $(\underline{n}=93: 22 \%)$ não possui dependente, conforme detalhado por empresa na Tabela 3.5. A empresa 7 tem maior número de dependentes: 59. É uma manufatura de equipamentos de medição e sua população é masculina.

Tabela 3.5 Dependentes por empresa.

\begin{tabular}{|c|c|c|c|c|c|c|c|}
\hline Empresa & Nenhum & $\mathbf{1}$ & $\mathbf{2}$ & $\mathbf{3}$ & $\mathbf{4}$ & $\mathbf{5}$ & Mais de 5 \\
\hline 1 & 7 & 3 & 4 & 4 & 1 & 0 & 0 \\
\hline 2 & 4 & 4 & 4 & 6 & 0 & 2 & 0 \\
\hline 3 & 6 & 4 & 4 & 2 & 4 & 0 & 0 \\
\hline 4 & 7 & 4 & 3 & 2 & 2 & 0 & 2 \\
\hline 5 & 4 & 7 & 4 & 2 & 1 & 0 & 0 \\
\hline 6 & 12 & 3 & 0 & 3 & 1 & 0 & 0 \\
\hline 7 & 3 & 2 & 3 & 5 & 3 & 4 & 0 \\
\hline 9 & 3 & 7 & 1 & 4 & 3 & 2 & 0 \\
\hline 10 & 7 & 4 & 3 & 4 & 0 & 2 & 0 \\
\hline 11 & 0 & 2 & 6 & 7 & 0 & 3 & 1 \\
\hline 12 & 3 & 3 & 2 & 5 & 5 & 2 & 0 \\
\hline 13 & 3 & 4 & 5 & 5 & 2 & 0 & 0 \\
\hline 14 & 1 & 3 & 4 & 8 & 3 & 0 & 0 \\
\hline 16 & 9 & 0 & 3 & 5 & 1 & 0 & 2 \\
\hline 18 & 2 & 7 & 6 & 2 & 3 & 0 & 0 \\
\hline 19 & 3 & 2 & 3 & 5 & 5 & 2 & 0 \\
\hline 20 & 5 & 4 & 4 & 4 & 1 & 1 & 0 \\
\hline 21 & 6 & 4 & 0 & 3 & 4 & 2 & 0 \\
\hline 22 & 5 & 2 & 3 & 5 & 2 & 3 & 0 \\
\hline 24 & 1 & 3 & 5 & 7 & 3 & 1 & 0 \\
\hline 25 & 2 & 1 & 1 & 5 & 7 & 2 & 0 \\
\hline TOTAL & 93 & $\mathbf{7 3}$ & $\mathbf{6 8}$ & $\mathbf{9 3}$ & $\mathbf{5 1}$ & $\mathbf{2 6}$ & $\mathbf{5}$ \\
\hline & & & & & & & \\
\hline
\end{tabular}




\section{$d$ Escolaridade}

A maior parte da população de empregados está composta por escolaridade entre 8a. série e segundo grau ( $\underline{n}=220: 52 \%$ ). A empresa 25 , com maior número de empregados com até $4 a$. série, é do ramo de metal primário. A certificação ISO 9000 e outros sistemas de qualidade enfatizam a educação formal dos empregados, especialmente quanto à conclusão do primeiro grau. Os dados mostram que a maioria das unidades está atendendo este requisito, conforme se pode verificar na Tabela 3.6.

Tabela 3.6 Escolaridade por empresa.

\begin{tabular}{|c|c|c|c|c|c|c|}
\hline Empresa & $\begin{array}{l}\text { Até } 4^{\mathrm{a}} \\
\text { Série }\end{array}$ & $\begin{array}{l}\text { Até } 8^{a} \\
\text { Série }\end{array}$ & $\begin{array}{l}\text { Até } 2^{\circ} \\
\text { Grau }\end{array}$ & $\begin{array}{l}\text { Faculdade } \\
\text { Incompleta }\end{array}$ & $\begin{array}{c}\text { Faculdade } \\
\text { Completa }\end{array}$ & Outras \\
\hline 1 & 5 & 7 & 4 & 1 & 3 & 0 \\
\hline 2 & 3 & 2 & 8 & 1 & 4 & 2 \\
\hline 3 & 2 & 5 & 6 & 2 & 5 & 0 \\
\hline 4 & 7 & 5 & 3 & 1 & 4 & 0 \\
\hline 5 & 1 & 8 & 6 & 2 & 1 & 2 \\
\hline 6 & 0 & 5 & 7 & 0 & 8 & 0 \\
\hline 7 & 0 & 2 & 5 & 3 & 9 & 1 \\
\hline 9 & 3 & 3 & 6 & 0 & 6 & 2 \\
\hline 10 & 0 & 4 & 10 & 0 & 4 & 2 \\
\hline 11 & 3 & 12 & 3 & 1 & 1 & 0 \\
\hline 12 & 3 & 8 & 6 & 2 & 1 & 0 \\
\hline 13 & 1 & 2 & 7 & 3 & 6 & 1 \\
\hline 14 & 2 & 5 & 6 & 2 & 4 & 0 \\
\hline 16 & 2 & 6 & 6 & 2 & 4 & 0 \\
\hline 18 & 0 & 1 & 9 & 4 & 4 & 2 \\
\hline 19 & 0 & 0 & 8 & 5 & 4 & 3 \\
\hline 20 & 3 & 5 & 5 & 0 & 6 & 0 \\
\hline 21 & 5 & 3 & 6 & 1 & 2 & 2 \\
\hline 22 & 5 & 7 & 3 & 3 & 2 & 0 \\
\hline 24 & 3 & 5 & 4 & 3 & 4 & 1 \\
\hline 25 & 9 & 5 & 2 & 0 & 3 & 1 \\
\hline TOTAL & 57 & 100 & 120 & 36 & 85 & 19 \\
\hline
\end{tabular}

e) Faixa salarial 
A faixa salarial da população de empregados, detalhada na Tabela 3.7, está concentrada entre $\mathrm{R} \$ 501,00$ a $\mathrm{R} \$ 3.000,00$ ( $\underline{\mathrm{n}}=258: 61 \%$ ). Esse dado parece estar acima do esperado em relação ao padrão salarial médio do pessoal de fábrica, que em geral é de aproximadamente de $R \$ 600,00$. A empresa 4 é a que possui maior número de pessoas com esta faixa salarial; ela pertence ao ramo de metais, excetuando o de equipamentos de transporte. A empresa que apresentou melhor índice de faixa salarial, entre os pesquisados, foi a de número 19, que é do ramo de químicos e produtos químicos.

Tabela 3.7 Faixa salarial por empresa.

\begin{tabular}{|c|c|c|c|c|c|}
\hline Empresa & Até $\mathbf{R} \$ 500,00$ & $\begin{array}{c}R \$ 501 \mathrm{a} \\
1.000\end{array}$ & $\begin{array}{c}R \$ 1.001 \mathrm{a} \\
3.000\end{array}$ & $\begin{array}{c}R \$ 3.001 \mathrm{a} \\
5.000\end{array}$ & $\begin{array}{c}\text { Mais de R\$ } \\
5.000\end{array}$ \\
\hline 1 & 8 & 5 & 3 & 1 & 1 \\
\hline 2 & 1 & 4 & 11 & 1 & 3 \\
\hline 3 & 2 & 10 & 3 & 2 & 3 \\
\hline 4 & 12 & 1 & 4 & 2 & 1 \\
\hline 5 & 6 & 9 & 5 & 0 & 0 \\
\hline 6 & 8 & 3 & 2 & 2 & 5 \\
\hline 7 & 2 & 0 & 10 & 5 & 3 \\
\hline 9 & 7 & 4 & 4 & 2 & 2 \\
\hline 10 & 4 & 8 & 5 & 2 & 1 \\
\hline 11 & 3 & 10 & 6 & 1 & 0 \\
\hline 12 & 5 & 8 & 7 & 0 & 0 \\
\hline 13 & 0 & 5 & 11 & 1 & 2 \\
\hline 14 & 1 & 7 & 11 & 1 & 0 \\
\hline 16 & 5 & 8 & 3 & 1 & 2 \\
\hline 18 & 0 & 5 & 11 & 2 & 2 \\
\hline 19 & 0 & 2 & 13 & 4 & 1 \\
\hline 20 & 5 & 5 & 8 & 1 & 1 \\
\hline 21 & 8 & 3 & 6 & 0 & 2 \\
\hline 22 & 9 & 5 & 4 & 2 & 0 \\
\hline 24 & 2 & 11 & 4 & 2 & 1 \\
\hline 25 & 2 & 9 & 5 & 3 & 0 \\
\hline TOTAL & 90 & 122 & 136 & 35 & 30 \\
\hline
\end{tabular}




\subsubsection{Gerência de recursos humanos}

\section{a) Níveis hierárquicos}

O perfil hierárquico desse grupo é heterogêneo. A gerência atua nos níveis que englobam da supervisão até a direção. Na Tabela 3.8 observa-se que a maioria é formada por gerentes. A lotação ocorre nas áreas de qualidade, benefícios, recursos humanos e medicina do trabalho. Alguns profissionais estavam no topo decisório ou logo abaixo dos diretores acionistas, respondiam pela direção geral da unidade, pela vice-presidência corporativa de recursos humanos e diretoria administrativa e financeira.

Os contatos iniciais para a pesquisa na empresa foram feitos, na maior parte das unidades, com os profissionais de supervisão e direção. Quando o executivo era da área de qualidade ou diretamente da produção, as negociações e o agendamento foram muito mais rápidos do que quando estavam lotados nas áreas de recursos humanos ou benefícios. Esta característica se repetiu mesmo no caso de cargos de recursos humanos de alta direção, como vice-presidência e diretoria de recursos humanos. Algumas das pesquisas só foram viabilizadas porque mesmo em caso de negativa na área de recursos humanos, foi solicitado um contato com as áreas referidas.

As limitações estavam associadas à autonomia de acesso aos empregados, à responsabilidade de gerar expectativas e à sobrecarga da área de recursos humanos. Um dos gerentes de recursos humanos contactado, que muitas vezes negou a pesquisa, mas aceitou colocar a pesquisadora em contato com o gerente 
de qualidade, afirmou: "Se der certo, eu sei que vai sobrar para mim." Após a realização da mesma, tendo inclusive respondido como representante da empresa, disse: "Pensei que fosse mais complicado."

$\mathrm{Na}$ prática, parece que a gerência de recursos humanos está no chão da fábrica e não nos escritórios de decisão ou know-how específico.

\section{b) Faixa salarial}

Prevaleceu na pesquisa a faixa salarial acima de $R \$ 5.000,00$, um salário diferenciado se comparado com o dos empregados. Esta diferença sociofuncional não demonstrou ser significativa nas percepções e no julgamento dos indicadores empresariais de qualidade de vida no trabalho - IEQVT.

\section{c) Dependentes}

O número de dependentes indica vínculos e compromissos familiares. Esse grupo parece ter vínculos familiares significativos. Apareceram duas faixas prevalentes: entre 2-3 e 3-4 dependentes, que totalizam 88\% da população. 
d) Faixa etária

A faixa etária, 27 a 53 anos, com maior concentração na faixa de 37-46, demonstra a composição de pessoas provavelmente amadurecidas profissionalmente.

Tabela 3.8 Perfil da gerência de recursos humanos.

\begin{tabular}{|c|c|c|c|c|}
\hline $\begin{array}{l}\text { Nível hierárquico } \\
n=24\end{array}$ & Supervisão: $29 \%$ (7) & Gerência: $50 \%$ (12) & Direção: $21 \%$ (5) & \\
\hline $\begin{array}{l}\text { Faixa salarial } \\
n=24\end{array}$ & $\begin{array}{l}R \$ 1.001,00-3.000,00 \\
24 \%(6)\end{array}$ & $\begin{array}{l}R \$ 3.001,00-5.000,00 \\
28 \%(7) \\
\end{array}$ & $\begin{array}{l}+\mathrm{R} \$ 5.000,00 \\
48 \%(12)\end{array}$ & \\
\hline $\begin{array}{l}\text { Escolaridade } \\
n=26\end{array}$ & $\begin{array}{l}\text { Faculdade incompleta } \\
8 \%(2)\end{array}$ & $\begin{array}{l}\text { Faculdade concluída } \\
73 \%(19)\end{array}$ & $\begin{array}{l}\text { Pós-graduação } \\
19 \%(5)\end{array}$ & \\
\hline $\begin{array}{l}\text { Dependentes } \\
n=26\end{array}$ & $\begin{array}{l}\text { Nenhum } \\
8 \%(2) \\
\end{array}$ & $\begin{array}{l}\text { Um a dois: } \\
46 \%(12)\end{array}$ & $\begin{array}{l}\text { Três a quatro: } \\
42 \%(11)\end{array}$ & $\begin{array}{l}+ \text { de } 5: \\
4 \%(1)\end{array}$ \\
\hline $\begin{array}{l}\text { Sexo } \\
n=26\end{array}$ & $\begin{array}{l}\text { Mulheres } \\
15 \%(4)\end{array}$ & $\begin{array}{l}\text { Homens } \\
85 \%(22)\end{array}$ & & \\
\hline $\begin{array}{l}\text { Idade } \\
n=25\end{array}$ & até $26: 0 \%$ & $\begin{array}{l}27-36: 20 \% \\
37-46: 44 \%\end{array}$ & $\begin{array}{l}47-56: 36 \% \\
\text { mais de } 56 \%\end{array}$ & \\
\hline
\end{tabular}




\subsection{COMPARAÇÕES ENTRE ESFORÇO E SATISFAÇÃO}

A comparação entre esforço e satisfação dos indicadores é apresentada de acordo com os seguintes critérios: organizacionais, biológicos, psicológicos, sociais e percepção pessoal de QVT. Dessa forma, é possível observar avaliações semelhantes e opostas. O Gráfico 3.3 mostra, numa escala de 0 a 10 pontos, que a maioria das médias se encontram em intervalo de 5 a 8 pontos. As contraposições mais acentuadas são:

- o maior esforço positivo da empresa é para a preservação da vida pessoal (média: 8,33), que não é correspondido pela satisfação dos empregados, cuja média é 6,30;

- as menores notas dos empregados são relativas ao atendimento aos filhos (média: 2,6), cesta básica (média: 2,8) e financiamento para cursos externos (média: 3,4). A maioria dos empregados pesquisados era composta por pessoas do sexo masculino, e os aspectos considerados maternos aparecem como fonte de insatisfação dos empregados. Aqui também ocorreu ausência de respostas;

- ginástica aparece com alta insatisfação em todos os segmentos: entre 0,6 (gerência de recursos humanos) e 2,5 (produção). Esta é uma variável atípica, pois ocorreram muitas respostas em branco, em razão da falta de atividade na maioria das empresas. Uma operária, do segmento eletroeletrônico sugeriu "ginástica para mulheres";

- rotinas de pessoal obteve maior nível de satisfação por parte dos empregados. Neste item, houve o menor coeficiente de variação, havendo portanto, maior homogeneidade de respostas; 
- carreira aparece com média mais baixa de satisfação na gerência de recursos humanos (média: 4,4 ) do que na média dos empregados (média: 5,5). Esse dado parece indicar maior insatisfação com relação aos esforços possíveis e menores expectativas de ascensão dos empregados. Isto é significativo se se consideram as análises de Dutra (1996) sobre a pouca consolidação de planos pessoais de carreira na empresa (ver Capítulo 1 - Fundamentação teórica);

- participação: há maior insatisfação por parte dos empregados com relação às oportunidades de participar de comitês de decisão. Este aspecto é citado por um empregado como "diálogo entre gerência e funcionários". Para a gerência de recursos humanos, este aspecto está mais associado à participação monetária nos resultados.

Gráfico 3.3 Comparação global de esforço e satisfação.

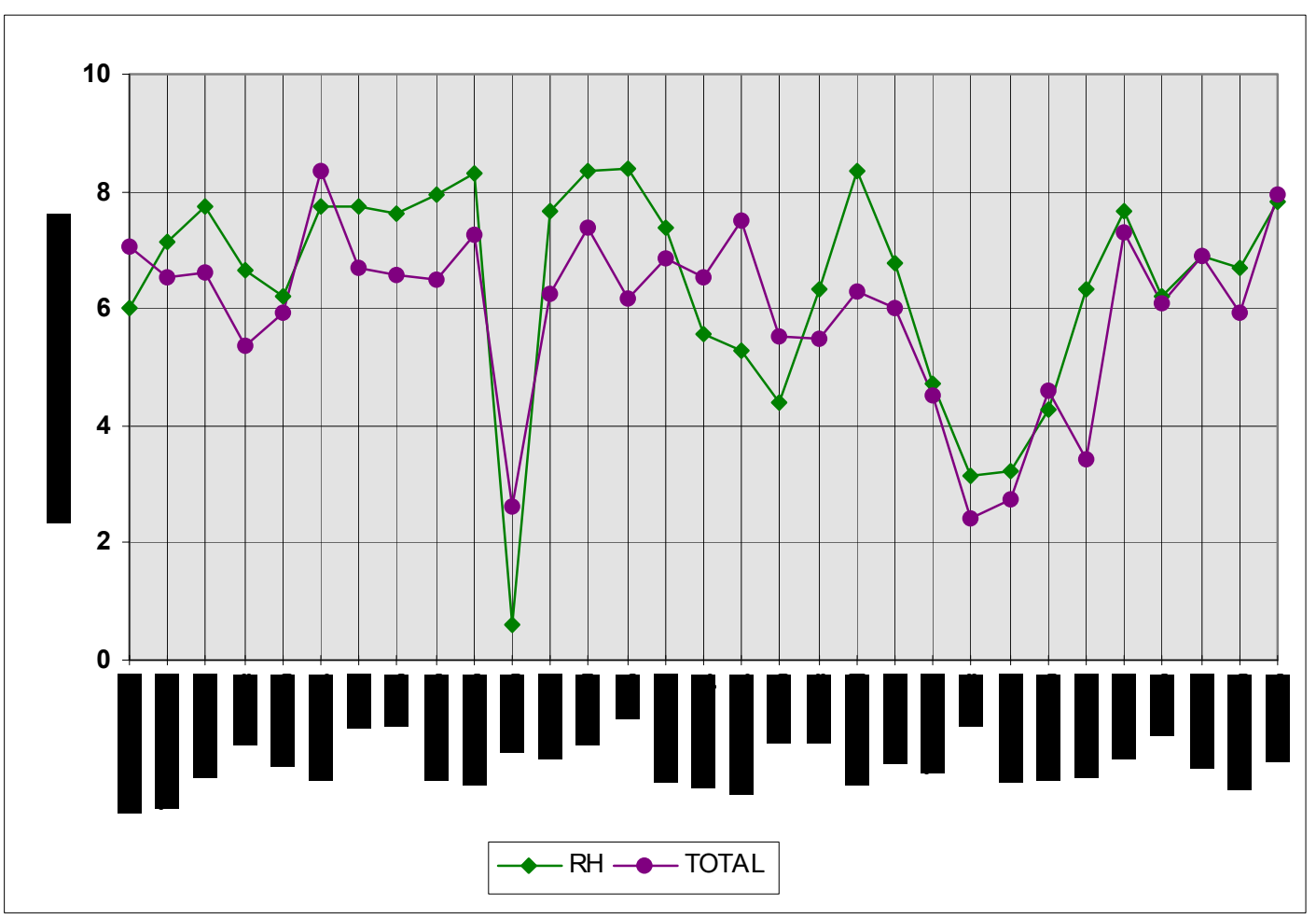


Ao analisar a matriz de correlação (Anexo 7), referente às avaliações dos funcionários, encontravam-se baixos índices de correlação, o que sugere heterogeneidade da amostra. Com isso, torna-se difícil tirar conclusões sobre relações das variáveis na totalidade da amostra. Por isso, considera-se que a melhor análise será feita por meio de segmentação da amostra em níveis hierárquicos.

A Tabela 3.9 permite uma comparação das notas médias das variáveis dos empregados. Observa-se dispersão dos dados, sugerindo que não se está trabalhando com uma amostra homogênea e, portanto, passível de segmentação.

Tabela 3.9 Dados das notas de satisfação (empregados).

\begin{tabular}{|l|c|c|c|c|c|}
\hline \multicolumn{1}{|c|}{ Foco da variável } & Mínimo & Máximo & Média & $\begin{array}{c}\text { Desvio- } \\
\text { padrão }\end{array}$ & $\begin{array}{c}\text { Coeficiente de } \\
\text { variação (\%) }\end{array}$ \\
\hline EM111, imagem & 0 & 10 & 7.05 & 2.18 & 30.92 \\
\hline EM112, T\&D & 0 & 10 & 6.55 & 2.64 & 40.31 \\
\hline EM113, processos e tecnologia & 0 & 10 & 6.62 & 2.41 & 35.44 \\
\hline EM114, comitês de decisão & 0 & 10 & 5.35 & 2.98 & 55.58 \\
\hline EM115, ausência de burocracia & 0 & 10 & 5.91 & 2.47 & 41.76 \\
\hline EM116, rotinas de pessoal & 0 & 10 & 8.35 & 1.94 & 23.30 \\
\hline $\begin{array}{l}\text { EM121, semanas de Prevenção - } \\
\text { SIPATs }\end{array}$ & 0 & 10 & 6.68 & 2.92 & 43.77 \\
\hline $\begin{array}{l}\text { EM122, riscos } \\
\text { ergonômicos/ambientais -PPRA }\end{array}$ & 0 & 10 & 6.58 & 2.64 & 40.19 \\
\hline EM123, ambulatório & 0 & 10 & 6.49 & 3.39 & 52.28 \\
\hline EM124, convênio médico & 0 & 10 & 7.26 & 2.80 & 38.62 \\
\hline EM125, ginástica & 0 & 10 & 2.62 & 3.39 & 129.41 \\
\hline EM126, refeições & 0 & 10 & 6.26 & 3.00 & 47.81 \\
\hline $\begin{array}{l}\text { EM127, saúde dos colegas e } \\
\text { superiores - PCSMO }\end{array}$ & 0 & 10 & 7.38 & 1.99 & 27.04 \\
\hline $\begin{array}{l}\text { EM128, comissão Interna } \\
\text { Prev.Acidentes - CIPA }\end{array}$ & 0 & 10 & 6.17 & 2.74 & 44.47 \\
\hline EM131, recrutamento e seleção & 0 & 10 & 6.86 & 2.36 & 34.39 \\
\hline $\begin{array}{l}\text { EM132, formas de avaliação do } \\
\text { desempenho }\end{array}$ & 0 & 10 & 6.53 & 2.73 & 41.87 \\
\hline EM133, camaradagem/ clima & 0 & 10 & 7.52 & 2.23 & 29.61 \\
\hline
\end{tabular}




\begin{tabular}{|l|l|l|l|l|l|}
\hline Organizacional & & & & & \\
\hline
\end{tabular}

Tabela 3.9 Dados das notas de satisfação (empregados - continuação).

\begin{tabular}{|l|c|c|c|c|c|}
\hline EM134, carreira & 0 & 10 & 5.53 & 2.94 & 53.15 \\
\hline EM135, salário & 0 & 10 & 5.48 & 2.72 & 49.67 \\
\hline EM136, vida pessoal & 0 & 10 & 6.30 & 2.80 & 44.48 \\
\hline EM141, convênios comerciais & 0 & 10 & 5.99 & 3.31 & 55.27 \\
\hline EM142, tempo livre/lazer & 0 & 10 & 4.50 & 3.42 & 75.98 \\
\hline EM143, filhos & 0 & 10 & 2.41 & 3.29 & 136.67 \\
\hline EM144, cesta básica & 0 & 10 & 2.76 & 3.39 & 130.09 \\
\hline EM145, previdência privada & 0 & 10 & 4.58 & 3.51 & 76.49 \\
\hline $\begin{array}{l}\text { EM146, financiamento } \\
\text { educação/cursos externos }\end{array}$ & 0 & 10 & 3.41 & 3.63 & 106.70 \\
\hline EM211, bem-estar & 0 & 10 & 7.30 & 2.19 & 30.03 \\
\hline EM212, tensão & 0 & 10 & 6.09 & 2.45 & 40.27 \\
\hline EM213, qualidade de vida pessoal & 0 & 10 & 6.91 & 2.29 & 30.21 \\
\hline $\begin{array}{l}\text { EM214, qualidade de vida da } \\
\text { empresa }\end{array}$ & 0 & 10 & 5.92 & 2.49 & 42.11 \\
\hline EM215, resultado para o trabalho & 0 & 10 & 7.95 & 1.98 & 24.96 \\
\hline
\end{tabular}

A seguir, apresentam-se os dados esforço e satisfação por níveis hierárquicos dos empregados. Os critérios são os da abordagem biopsicossocial.

\subsubsection{Critério organizacional}

Os indicadores analisados foram:

- Imagem da empresa.

- Desenvolvimento e treinamento.

- Melhorias de processos de trabalho e tecnologia.

- Participação em comitês de decisão.

- Redução da burocracia.

- Rotinas de pessoal. 
Gráfico 3.4 Comparação no critério organizacional.

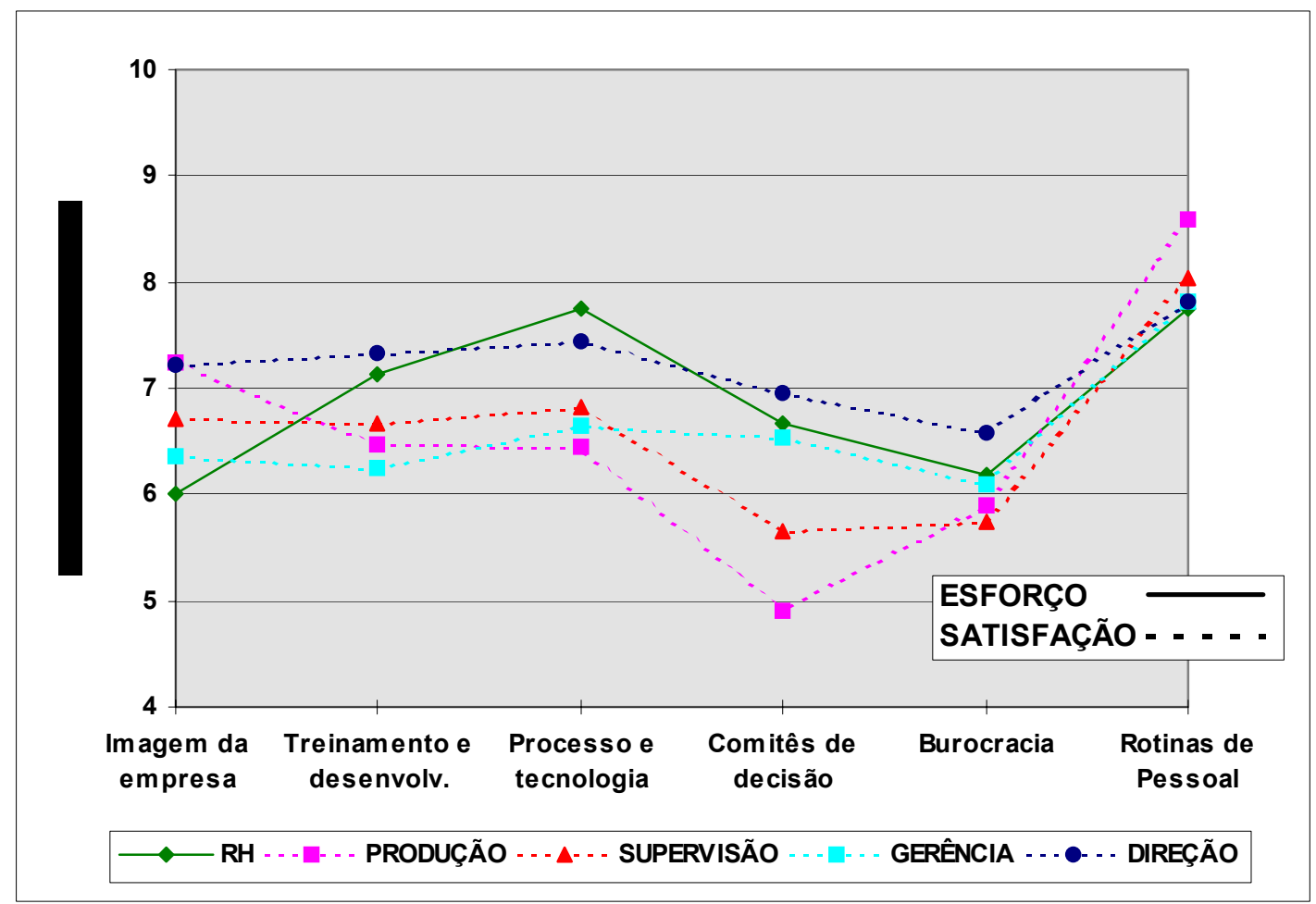

Observando-se o Gráfico 3.4, destacam-se comitês de decisão, com menor média: 4,9 e rotinas de pessoal com maior média: 8,6. Estas tendência são acompanhadas pelos outros níveis de empregados, e vão refletir-se na análise fatorial dos empregados, especialmente a variável rotinas de pessoal no Fator 4, prestação de serviços e comitês de decisão, nos tipos de gestão da qualidade de vida.

A imagem da empresa é avaliada negativamente no sentido do esforço (média: 6,0) e avaliada mais positivamente pela produção (média: 7,3 ) e direção (média: 7,2). Os extremos coincidem em termos de percepção da empresa. Embora a média não seja muito diferente da dos demais níveis, esta sinalização já 
foi percebida em estudo anterior, em pesquisa sobre somatização no trabalho (Limongi Gasparini, 1990).

Processos e tecnologia obteve a média mais alta de esforço, que só é compartilhada pela direção da unidade da empresa.

\subsubsection{Critério biológico}

Os indicadores analisados foram:

- SIPAT - Semana Interna de Prevenção de Acidentes.

- PPRA - Programa de Prevenção de Riscos Ambientais.

- Ambulatório.

- Convênio médico.

- Ginástica durante o trabalho.

- Refeições oferecidas pela empresa.

- PCSMO - Controle Médico e Saúde Ocupacional.

- Atuação da CIPA. 
Gráfico 3.5 Critério biológico.

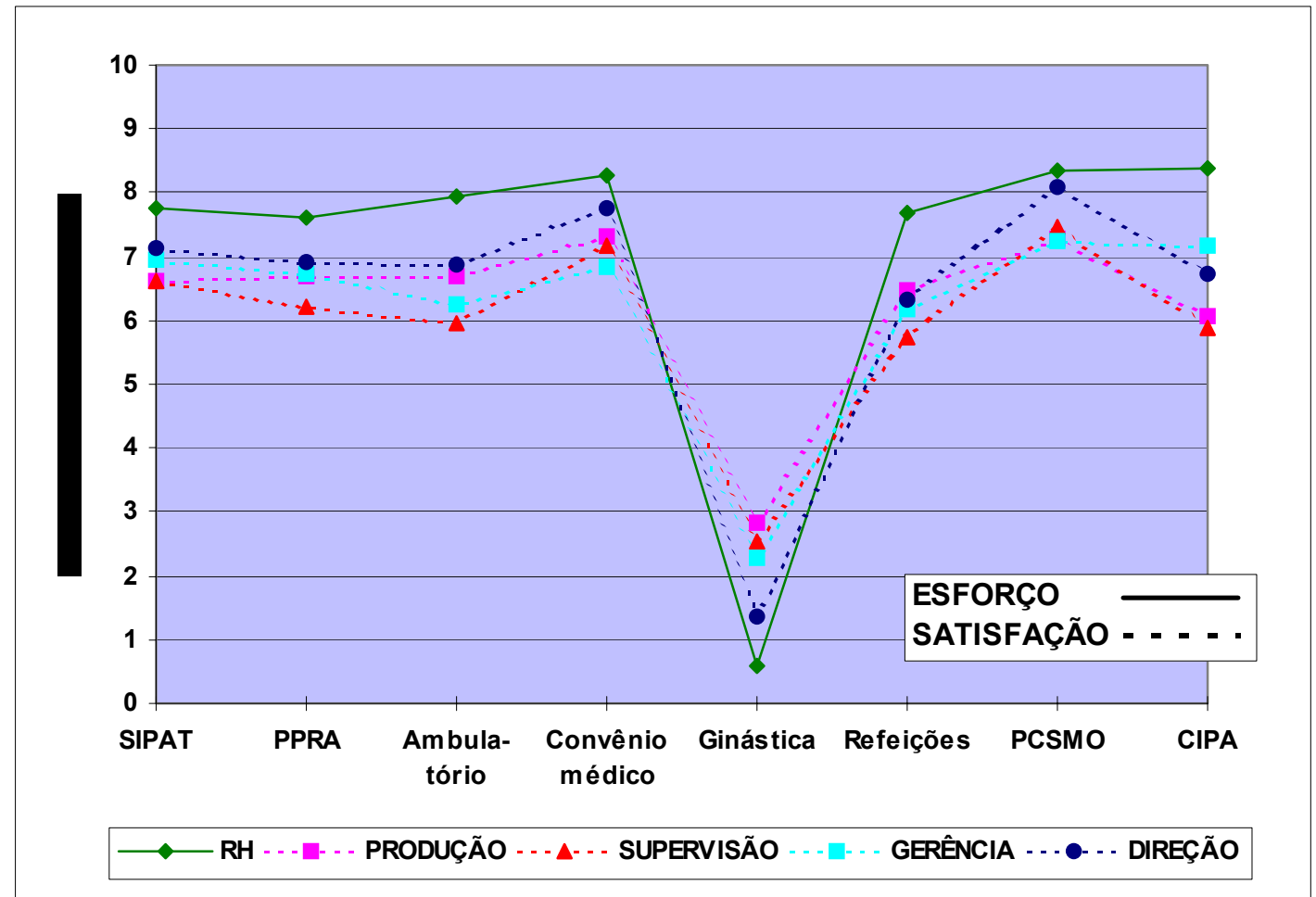

O Gráfico 3.5 é o mais homogêneo em termos de médias na satisfação e no esforço. A ginástica foi um indicador de extremo. Só uma das empresas a possuía como programa; as demais não tinham programa de ginástica e nem demonstravam intenção de tê-lo (média: 0,6). Houve interesse nessa ação e, entre as sugestões de melhorias e melhores programas, ela aparece citada várias vezes pelos empregados.

As médias dos indicadores são as mais altas do conjunto, o que se confirmou no diferencial da composição dos conglomerados.

O convênio médico aparece com alto esforço (média: 8,3), que é menos compartilhado com o pessoal da gerência (média: 6,8). 
As refeições aparecem com maior esforço (média: 7,7), que não é compartilhado em termos de satisfação, especialmente pelo nível da supervisão (média: 5,7).

O controle de riscos ambientais - PPRA - o controle de saúde ocupacional PCMSO - e as comissões internas de prevenção de acidentes - CIPAs - são programas obrigatórios por lei. As médias de esforço são significativamente mais altas que a satisfação em todos os níveis hierárquicos.

\subsubsection{Critério psicológico}

Os indicadores desse critério são:

- Confiança nos critérios de recrutamento e seleção.

- Ferramentas de avaliação de desempenho.

- Gestão do clima organizacional.

- Plano de carreira.

- Administração de salários.

- Vida pessoal dos empregados. 
Gráfico 3.6 Critério psicológico.

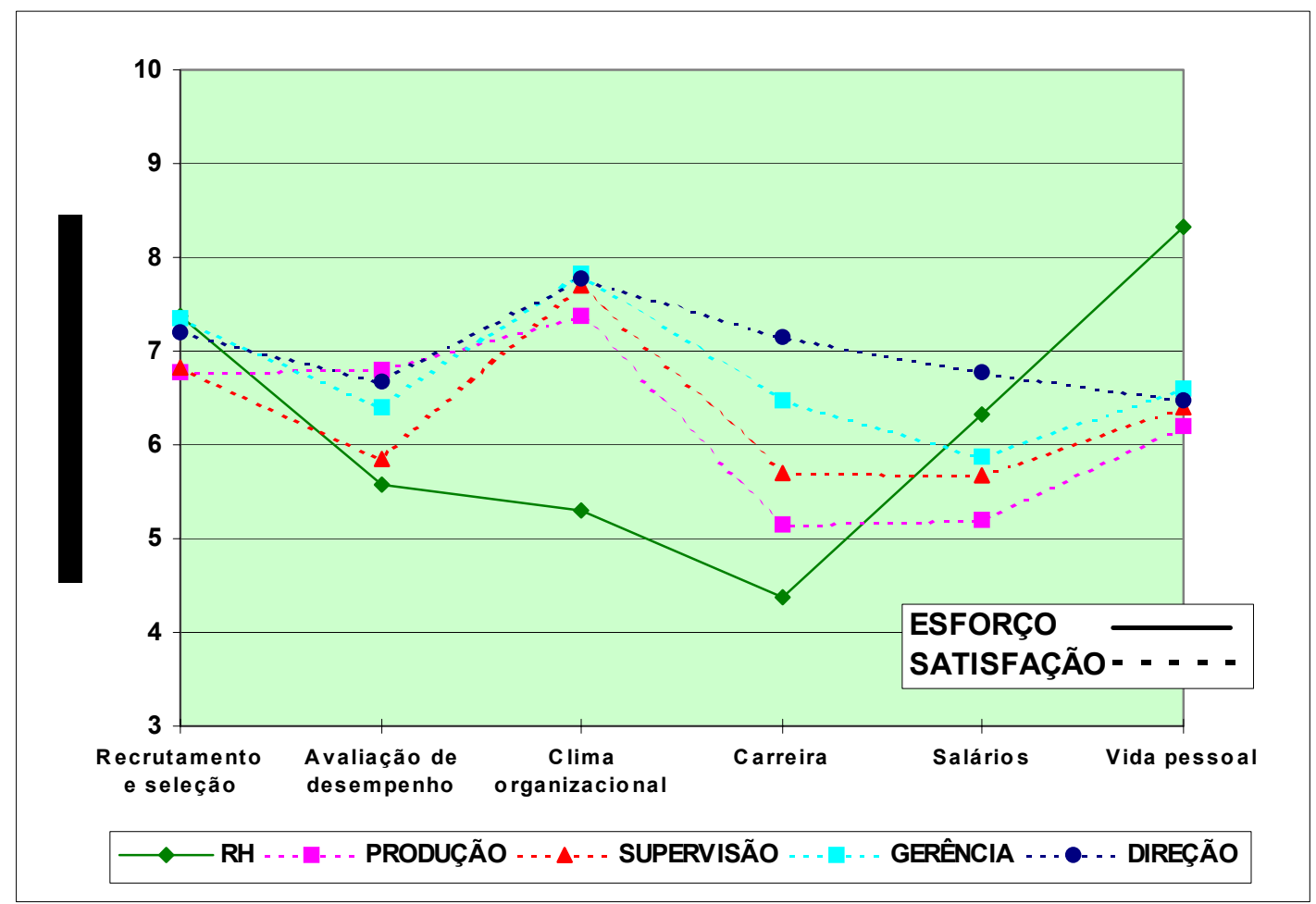

O Gráfico 3.6 apresenta extremos muito interessantes entre esforço $x$ satisfação. O clima organizacional, responsabilidade da gestão de recursos humanos, tem média de insatisfação moderada com esforço (média: 4,4) que não é compartilhada pelos diversos níveis, especialmente pela direção.

Em contrapartida, a vida pessoal apresenta média alta de esforço (média: 8,3), acima da satisfação de todos (médias entre 6,2 e 6,5).

O recrutamento e a seleção aparecem com média levemente superior em esforço (média: 7,4) e menor satisfação na produção (média: 6,8). 
Esse critério é formado pelos indicadores:

- Convênios comerciais (farmácia, supermercado, compras etc.)

- Atividades para o tempo livre (esportes, recreação, dominó, eventos etc.).

- Atendimento aos filhos (creche, berçário, escola etc.).

- Fornecimento de cesta básica.

- Administração da previdência privada.

- Financiamento da educação (faculdade, idiomas, cursos técnicos e profissionalizantes etc).

Gráfico 3.7 Critério social.

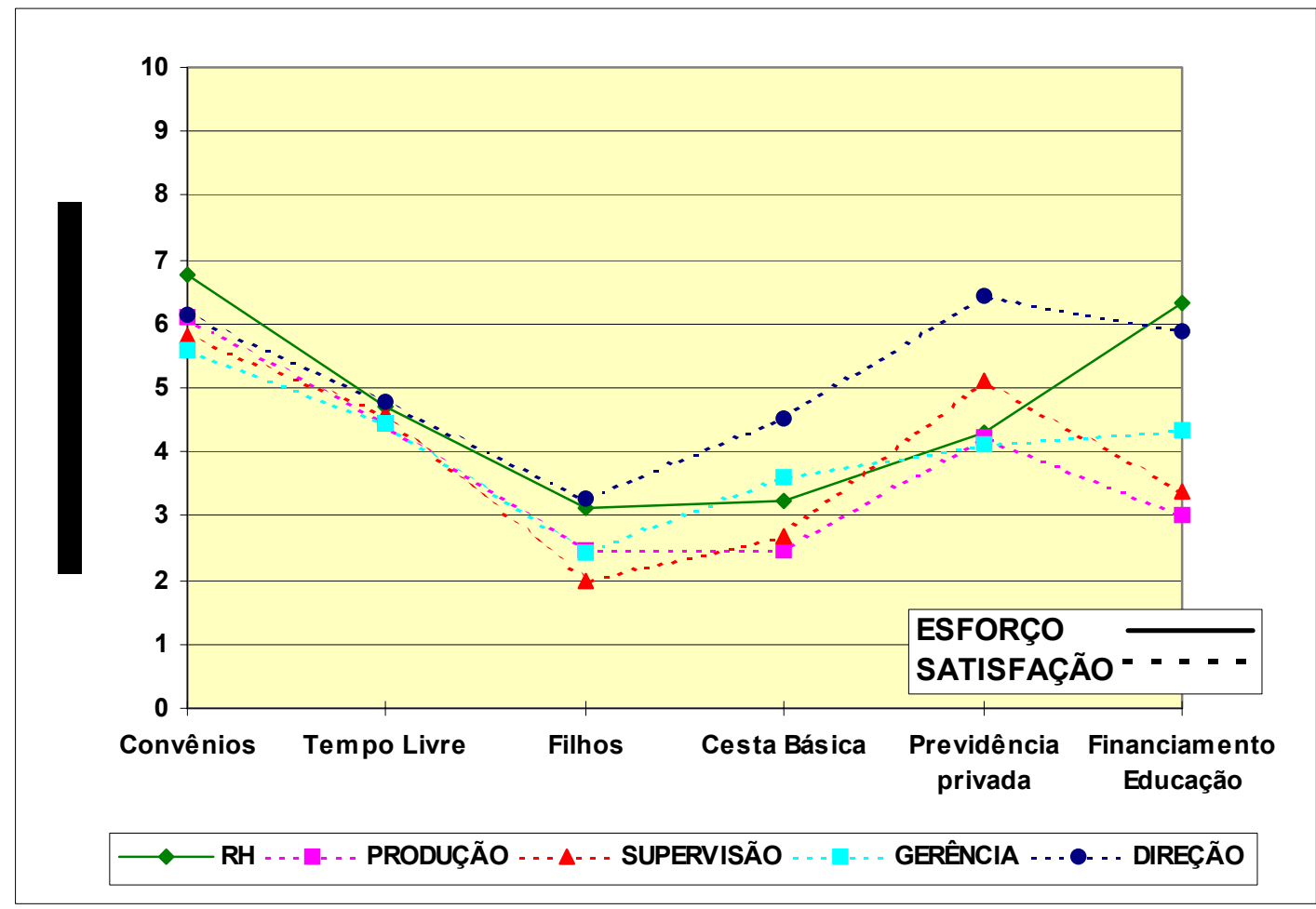


O Gráfico 3.7 apresenta a menor média entre os demais critérios. O curioso é que qualidade de vida, em uma visão mais assistencialista, está muito associada a esse critério.

O que mais se destaca é o atendimento aos filhos dos empregados. A média é muito baixa em todos os níveis. A menos baixa é a média da direção $(2,3)$, talvez porque considerem responsabilidade da gestão.

A previdência privada aparece com média mais alta na direção $(6,4)$, o que reflete exatamente as verbalizações obtidas. Esse tem sido o único nível que recebe o benefício, mas só em algumas empresas. É uma ação recente nas empresas.

Financiamento para cursos externos aparece como esforço moderado (média: 6,3) contraposto pela insatisfação, especialmente da produção (média: $3,4)$. Outro dado que é confirmado pelas verbalizações e sugestões escritas dos empregados.

\subsubsection{Percepção pessoal}

A medida nesse item é apenas de satisfação. A intenção é conhecer a percepção pessoal de QVT e sentir o estado de bem-estar das pessoas, no momento da pesquisa. Os indicadores que compõem este foco são:

- Sensação de bem-estar no trabalho.

- Estado geral de tensão (stress) pessoal. 
- Grau de satisfação com sua Qualidade de Vida.

- Adequação das ações de QVT de sua empresa.

- Importância da Qualidade de Vida no Trabalho para o resultado de seu trabalho.

Gráfico 3.8 Critério de percepção pessoal.

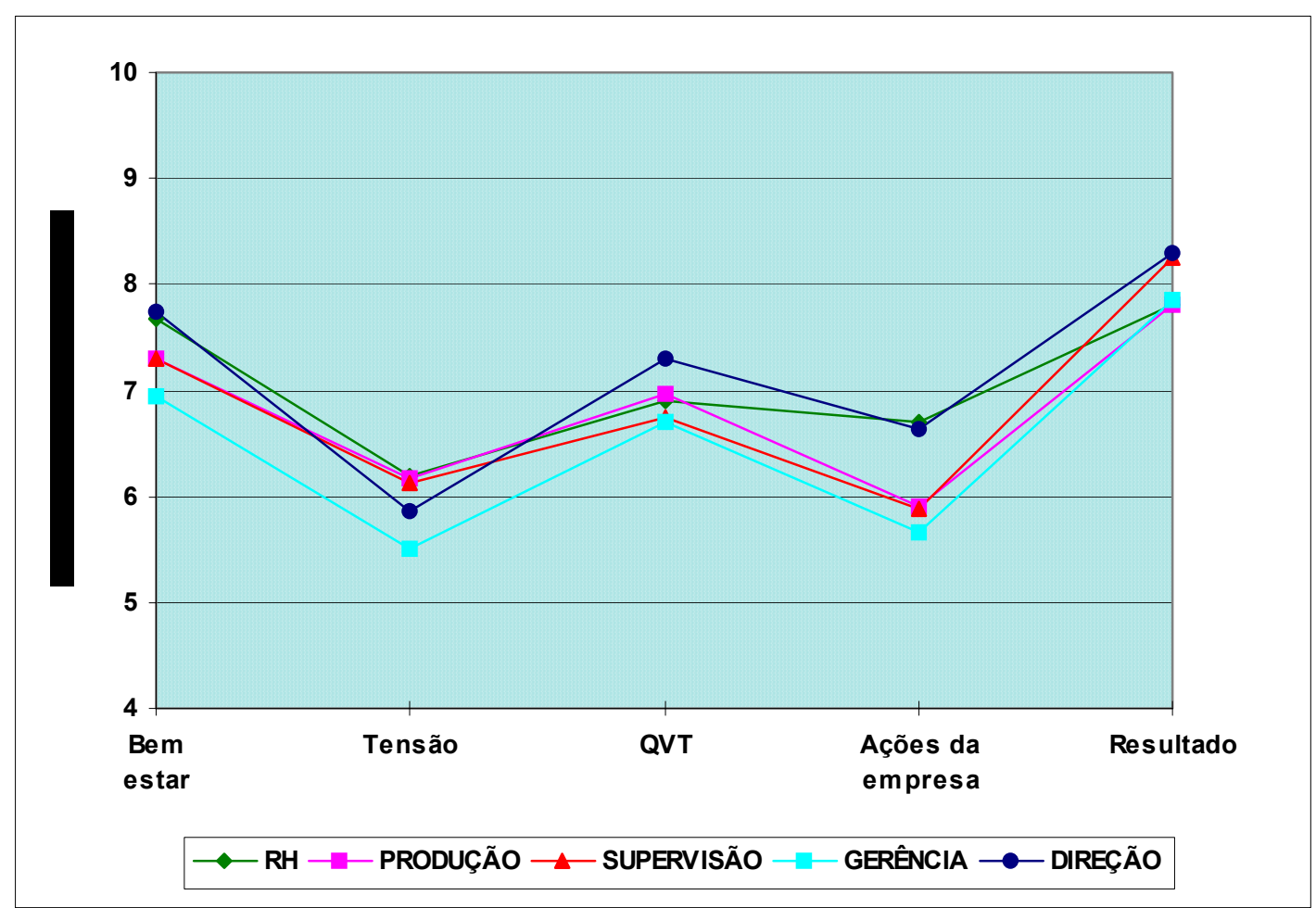

O Gráfico 3.8 aponta algumas dissonâncias pessoais sobre a Qualidade de Vida. As médias para sensação de bem-estar no trabalho são tão altas $(6,9$ a 7,7$)$ quanto a valorização da QVT para os resultados do trabalho (médias: 8,3 a 7,8). No entanto, a sensação de tensão, associada ao stress, apresenta médias mais 
baixas, especialmente nas gerências $(5,5)$ - elos de ligação entre o estratégico e o operacional.

A pertinência das ações de QVT promovidas pela empresa é vista de forma moderadamente satisfatória, especialmente pelas gerências. Essas médias confirmam as demandas de gerenciamento de stress, especialmente no segmento gerências.

3.2.6 Sinais clínicos de stress

Os sinais clínicos de stress foram identificados por meio das ocorrências de saúde-doença; são importantes sinais de stress e de exposição a condições adversas de trabalho. Na Tabela 3.10, observa-se que o recurso mais utilizado é o convênio médico, em todos os níveis; empregados do setor de produção e os de nível de gerência de recursos humanos, percentualmente, são os que mais a utilizam.

O uso do ambulatório é mais utilizado pela produção e, em seguida, pela direção. A gerência que apresentou a média mais baixa para tensão, decorrente de stress, aparece com a menor percentagem de uso do ambulatório médico. Esse pode ser um indicador de atitude de recolhimento quanto a seu enfrentamento de stress.

Remédios aparecem em percentagens semelhantes, altas, em todos os níveis. Esse parece ser um hábito tipicamente brasileiro: medicação como hábito de vida. 
Tabela 3.10 Ocorrência de saúde.

\begin{tabular}{|l|c|c|c|c|c|c|}
\hline $\begin{array}{c}\text { Ocorrências de } \\
\text { Saúde }\end{array}$ & RH & Produção & Supervisão & Gerência & Direção & Total \\
\hline Remédios & 50,0 & 44,7 & 50,0 & 44,1 & 48,2 & 46,2 \\
\hline Hospital & 3,9 & 11,0 & 4,9 & 0,0 & 3,7 & 8,1 \\
\hline Pronto-socorro & 11,5 & 23,9 & 15,4 & 6,0 & 18,5 & 20,0 \\
\hline Convênio & 73,1 & 74,1 & 66,4 & 64,7 & 59,3 & 70,5 \\
\hline Ambulatório & 42,3 & 57,3 & 49,0 & 38,2 & 55,6 & 53,6 \\
\hline Faltas & 30,8 & 42,0 & 21,2 & 11,8 & 18,5 & 32,9 \\
\hline
\end{tabular}

Não é intenção desta pesquisa aprofundar comparações entre as unidades certificadas. Para ilustrar as origens dos dados e permitir melhor visualização, incluem-se na pesquisa dados das médias de todos os indicadores avaliados pelos empregados. 


\subsubsection{Conceito de Qualidade de Vida no Trabalho}

Nas respostas obtidas dos questionários (Anexo 1a e b), as pessoas escolhiam por ordem de importância as três palavras que significassem QVT. As alternativas estavam distribuídas com os mesmos critérios biopsicossociais.

Quadro 3.1 Escolhas das palavras-chaves de qualidade de vida no trabalho.

\begin{tabular}{|c|c|c|c|}
\hline Critério & Palavra-chave & Empregados & Gerências RH \\
\hline Organizacional & $\begin{array}{l}\text { - Investimento } \\
\text { - Humanismo } \\
\text { - Competitividade }\end{array}$ & $\begin{array}{l}n=48: 4 \% \\
n=99: 8 \% \\
n=42: 4 \%\end{array}$ & $\begin{array}{l}n=3: 4 \% \\
n=8: 11 \% \\
n=4: 5 \% \\
\\
\quad n=15: 21 \%\end{array}$ \\
\hline Biológicas & $\begin{array}{l}\text { - Saúde } \\
\text { - Segurança } \\
\text { - Ausência de } \\
\text { acidentes } \\
\end{array}$ & $\begin{array}{l}n=186: 15 \% \\
n=179: 15 \% \\
n=62: 5 \%\end{array}$ & $\begin{array}{l}n=6: 8 \% \\
n=5: 7 \% \\
n=5: 7 \% \\
\\
\quad n=16: 23 \%\end{array}$ \\
\hline Psicológica & $\begin{array}{l}\text { - } \text { Amor } \\
\text { - Paz } \\
\text { - Realização pessoal }\end{array}$ & $\begin{array}{l}n=38: \quad 3 \% \\
n=55: \quad 5 \% \\
n=148: 12 \%\end{array}$ & 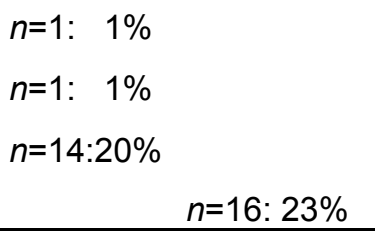 \\
\hline Social & $\begin{array}{l}\text { - } \text { Confiança } \\
\text { - Amizade } \\
\text { - Responsabilidade }\end{array}$ & $\begin{array}{l}n=138: 11 \% \\
n=56: 5 \% \\
n=160: 13 \% \\
\end{array}$ & $\begin{array}{l}n=10: 14 \% \\
n=3: \quad 4 \% \\
n=10: 14 \% \\
\quad n=23: 33 \%\end{array}$ \\
\hline & - Totais & $n=1211: 100 \%$ & $n+70: 100 \%$ \\
\hline
\end{tabular}


Palavras-chave para QVT - números absolutos

\begin{tabular}{|c|c|c|c|c|c|c|c|c|c|c|c|c|c|c|c|c|c|c|}
\hline Palavras-chave & Pro & duç & & Su & erv & & $\mathrm{Ge}$ & ên & & Di & çã & & En & preg & & G. & २. $\mathrm{H}$ & \\
\hline 1.confiança & 34 & 16 & 30 & 15 & 7 & 8 & 7 & 8 & 1 & 7 & 2 & 3 & 63 & 33 & 42 & 3 & 3 & 4 \\
\hline 2.segurança & 36 & 54 & 26 & 7 & 22 & 9 & 2 & 5 & 4 & 4 & 5 & 5 & 49 & 86 & 44 & 4 & 0 & 1 \\
\hline 3.paz & 16 & 17 & 11 & 0 & 4 & 9 & 0 & 0 & 1 & 1 & 0 & 0 & 17 & 21 & 15 & 1 & 0 & 0 \\
\hline 4.investimento & 5 & 5 & 14 & 5 & 3 & 11 & 1 & 2 & 0 & 0 & 1 & 0 & 11 & 11 & 25 & 0 & 1 & 2 \\
\hline 5.humanismo & 21 & 16 & 17 & 14 & 8 & 4 & 3 & 3 & 5 & 2 & 2 & 0 & 40 & 29 & 26 & 4 & 2 & 4 \\
\hline 6.saúde & 68 & 35 & 23 & 26 & 12 & 4 & 5 & 3 & 2 & 0 & 2 & 1 & 99 & 52 & 30 & 2 & 3 & 1 \\
\hline 7.competência & 2 & 7 & 7 & 2 & 4 & 9 & 1 & 2 & 4 & 0 & 0 & 1 & 5 & 13 & 21 & 1 & 1 & 2 \\
\hline 8.ausência de acidentes & 12 & 21 & 11 & 1 & 5 & 5 & 0 & 0 & 1 & 1 & 1 & 1 & 14 & 27 & 18 & 1 & 2 & 2 \\
\hline 9.amor & 8 & 10 & 10 & 1 & 4 & 1 & 0 & 0 & 0 & 0 & 0 & 0 & 9 & 14 & 11 & 1 & 0 & 0 \\
\hline 10.realização pessoal & 17 & 17 & 25 & 21 & 12 & 20 & 7 & 4 & 5 & 7 & 4 & 7 & 52 & 37 & 57 & 3 & 8 & 1 \\
\hline 11.amizade & 4 & 12 & 23 & 3 & 3 & 2 & 0 & 1 & 1 & 0 & 2 & 2 & 7 & 18 & 28 & 0 & 1 & 2 \\
\hline 12.responsabilidade & 22 & 31 & 46 & 1 & 13 & 19 & 4 & 2 & 6 & 3 & 5 & 15 & 30 & 51 & 76 & 3 & 2 & 5 \\
\hline Totais & $\begin{array}{l}24 \\
5\end{array}$ & $\begin{array}{l}24 \\
1\end{array}$ & $\begin{array}{l}24 \\
3\end{array}$ & 96 & 97 & 95 & 30 & 30 & 30 & 25 & 24 & 25 & $\begin{array}{l}39 \\
6\end{array}$ & $\begin{array}{l}39 \\
2\end{array}$ & $\begin{array}{l}39 \\
3\end{array}$ & 23 & 23 & 24 \\
\hline
\end{tabular}




\section{Palavras-chaves para QVT- PORCENTAGENS}

\begin{tabular}{|c|c|c|c|c|c|c|c|c|c|c|c|c|c|c|c|c|c|c|}
\hline Palavras-chave & \multicolumn{3}{|c|}{$\begin{array}{l}\text { Produ- } \\
\text { ção }\end{array}$} & \multicolumn{3}{|c|}{$\begin{array}{l}\text { Super- } \\
\text { visão }\end{array}$} & \multicolumn{3}{|c|}{ Gerência } & \multicolumn{3}{|c|}{ Direção } & \multicolumn{3}{|c|}{$\begin{array}{l}\text { Empre- } \\
\text { gados }\end{array}$} & \multicolumn{3}{|c|}{ G. R. H. } \\
\hline 1.confiança & 14 & 7 & 12 & 16 & 7 & 8 & 23 & 27 & 3 & 28 & 8 & 12 & 16 & 8 & 11 & 13 & 13 & 17 \\
\hline 2.segurança & 15 & 22 & 11 & 7 & 23 & 9 & 7 & 17 & 13 & 16 & 21 & 20 & 12 & 22 & 11 & 17 & 0 & 4 \\
\hline 3.paz & 7 & 7 & 5 & 0 & 4 & 3 & 0 & 0 & 3 & 4 & 0 & 0 & 4 & 5 & 4 & 4 & 0 & 0 \\
\hline 4.investimento & 2 & 2 & 6 & 5 & 3 & 12 & 3 & 7 & 0 & 0 & 4 & 0 & 3 & 3 & 6 & 0 & 4 & 8 \\
\hline 5.humanismo & 9 & 7 & 7 & 15 & 8 & 4 & 10 & 10 & 17 & 8 & 8 & 0 & 10 & 7 & 7 & 17 & 9 & 17 \\
\hline 6.saúde & 28 & 15 & 9 & 17 & 12 & 4 & 17 & 10 & 7 & 0 & 8 & 4 & 25 & 13 & 8 & 9 & 13 & 4 \\
\hline 7.competência & 1 & 3 & 3 & 2 & 4 & 9 & 3 & 7 & 13 & 0 & 0 & 4 & 1 & 3 & 5 & 4 & 4 & 8 \\
\hline 8.ausência de acidentes & 5 & 9 & 5 & 1 & 5 & 5 & 0 & 0 & 3 & 4 & 4 & 4 & 4 & 7 & 6 & 4 & 9 & 8 \\
\hline 9.amor & 3 & 4 & 4 & 1 & 4 & 1 & 0 & 0 & 0 & 0 & 0 & 0 & 2 & 4 & 3 & 4 & 0 & 0 \\
\hline 10.realização pessoal & 7 & 7 & 10 & 22 & 12 & 21 & 23 & 13 & 17 & 28 & 17 & 28 & 13 & 9 & 15 & 13 & 35 & 4 \\
\hline 11.amizade & 2 & 5 & 9 & 3 & 3 & 2 & 0 & 3 & 3 & 0 & 8 & 8 & 2 & 5 & 7 & 0 & 4 & 8 \\
\hline 12.responsabilidade & 9 & 13 & 19 & 1 & 13 & 20 & 13 & 7 & 20 & 12 & 21 & 20 & 8 & 13 & 19 & 13 & 9 & 21 \\
\hline
\end{tabular}

A escolha das palavras-chave foi mais acentuada no critério biológico, enquanto o critério organizacional foi pouco citado. A palavra saúde, embora colocada na primeira linha da segunda coluna para não facilitar sua escolha impulsiva, foi a mais escolhida, seguida de segurança, o que revela a visão bem tradicional da Qualidade de Vida no trabalho.

No critério psicológico, aparece a realização pessoal, importante dado, já que a maioria das respostas provavelmente da produção parece ter este aspecto poucas vezes atingido. 


\subsection{ANÁLISE FATORIAL}

Diante do total de variáveis do problema pesquisado, buscou-se, conforme o plano de pesquisa, reduzir os indicadores em fatores que pudessem apresentar novos conceitos e critérios de análise de QVT - Qualidade de Vida no Trabalho. A análise fatorial foi realizada para as variáveis dos empregados (EM) e das gerências de recursos humanos $(\mathrm{RH})$, separadamente. Todas as variáveis têm escala de zero a dez; portanto onze pontos. No caso dos empregados, esses mesmos escores fatoriais foram utilizados para a análise de conglomerados.

Os fatores foram extraídos por meio da análise de componentes principais com rotação ortogonal de $k$ fatores, em que $k$ é o número de autovalores maiores que um. A matriz não rotacionada indica de maneira preliminar o número de fatores a extrair, e os fatores resultantes apresentam-se em ordem de importância. O primeiro fator acumula a maior parte da variância, o segundo fator e os fatores subseqüentes baseiam-se na porção residual da variância. Cada fator é então responsável por sucessivas porções menores de variância.

Apresentam-se no Quadro 3.2 os focos das variáveis analisadas. 
Quadro 3.2 Foco das variáveis independentes e dependentes.

111 Imagem

113 Processos e tecnologia

115 Ausência de burocracia

121 SIPATs

123 Ambulatório

125 Ginástica

127 Saúde - PCSMO

131 Recrutamento e seleção

133 Camaradagem/ clima

135 Salário

141 Convênios comerciais

143 Filhos

145 Previdência privada

211 Bem-estar

213 Qualidade de vida pessoal

215 Resultado da QVT para o trabalho
112 T\&D

114 Comitês de decisão

116 Rotinas de pessoal

122 Riscos PPRA

124 Convênio médico

126 Refeições

128 CIPA

132 Avaliação do desempenho

134 Carreira

136 Vida pessoal

142 Tempo livre/lazer

144 Cesta básica

146 Financiamento de cursos

212 Tensão

214 Qualidade de vida da empresa

Um bom resultado de análise fatorial é aquele que explica grande porção de variância com poucos fatores. A informação contida na matriz fatorial não rotacionada, constante do Anexo 4, 2a e b, Matriz não rotacionada e Matriz Rotacionada. A matriz fatorial não rotacionada representa $58 \%$ do total da variância, com quatro fatores dos empregados, conforme a Tabela 4.2a do Anexo 4.

Discute-se cada fator com base na Tabela 3.11 (pg.181). Quanto à margem de explicação fatorial, há na população dos empregados $58 \%$ da análise de variância, o que para ciências humanas está um pouco abaixo do desejável que é 
entre 60 e $80 \%$. No entanto, acredita-se que, dada a natureza do tema, inclusive com poucos dados quantitativos anteriores, analisaremos os resultados com esta margem, considerando todas as limitações da não-generalização dos dados.

\subsubsection{Fatores dos empregados}

As variáveis EM125, ginástica, EM143, filhos, EMP144, cesta básica, EM145, previdência privada e EM146, financiamento de cursos, não foram utilizadas, dado o alto índice de notas zero nas respostas dos empregados; foram, porém, variáveis muito ilustrativas, na comparação das tendências das empresas para implementar ou não os programas de ginástica, atendimento aos filhos, como creches, cesta básica e financiamento à educação, como já descrito nas análises exploratórias de comparações das médias por nível hierárquico.

As variáveis atendimento às rotinas de pessoal e oportunidade de distração são as menos explicadas pelos fatores: 34 e $32 \%$, respectivamente.

As variáveis EM112, T\&D, EM121, SIPATs e EM141, convênios comerciais, ao contrário das anteriores, apresentam percentuais altos: entre 73 e $77 \%$ de explicação pela solução fatorial. 
3.3.1.1 Fator 1, atuação organizacional

O Fator 1, atuação organizacional, é composto pelas variáveis:

- EM112, T\&D.

- EM113, processos e tecnologias.

- EM114, comitês de decisão.

- EM115, ausência de burocracia.

- EM134, carreira.

- EM111, imagem.

- EM132, avaliação do desempenho.

Esse conjunto de variáveis está relacionado ao significado do trabalho na empresa, com suas implicações de reconhecimento, confiança e pontualidade de documentação de pessoal.

As variações de média geral são pequenas. As médias das variáveis desse critério organizacional são menores do que a de outros critérios. Explica-se: pode ter ocorrido um viés de posição por serem as primeiras variáveis que apareciam no questionário. No entanto, esse viés é util para a interpretação: uma provável exigência negativa com os esforços da empresa.

Do grupo de variáveis que formam o Fator 1, Atuação Organizacional, as variáveis EM111, imagem, EM112, T\&D, EM113, processos e tecnologia e EM132, avaliação do desempenho aparecem em 60\% da amostra com notas de 710. As demais variáveis atingiram neste mesmo intervalo (7-10) porcentagem de respostas entre 42 e $46 \%$. 
Esses dados demonstram a importância positiva dessas variáveis na valorização da capacidade gerencial da empresa. Podem ser confirmados no Gráfico 3.3, comparativos das médias descritivas por nível hierárquico.

As cargas fatoriais do Fator 1, atuação organizacional, são apresentadas no Gráfico 3.9. Observa-se a satisfação com a valorização da qualificação profissional e com processos de melhorias da tecnologia. A EM132, avaliação do desempenho, é uma variável que compõe o fator com a menor carga fatorial: 0,448, mas com $60 \%$ de notas entre $7-10$, que podem ser interpretadas como satisfação do empregado.

Gráfico 3.9 Fator 1, atuação organizacional (39\%).

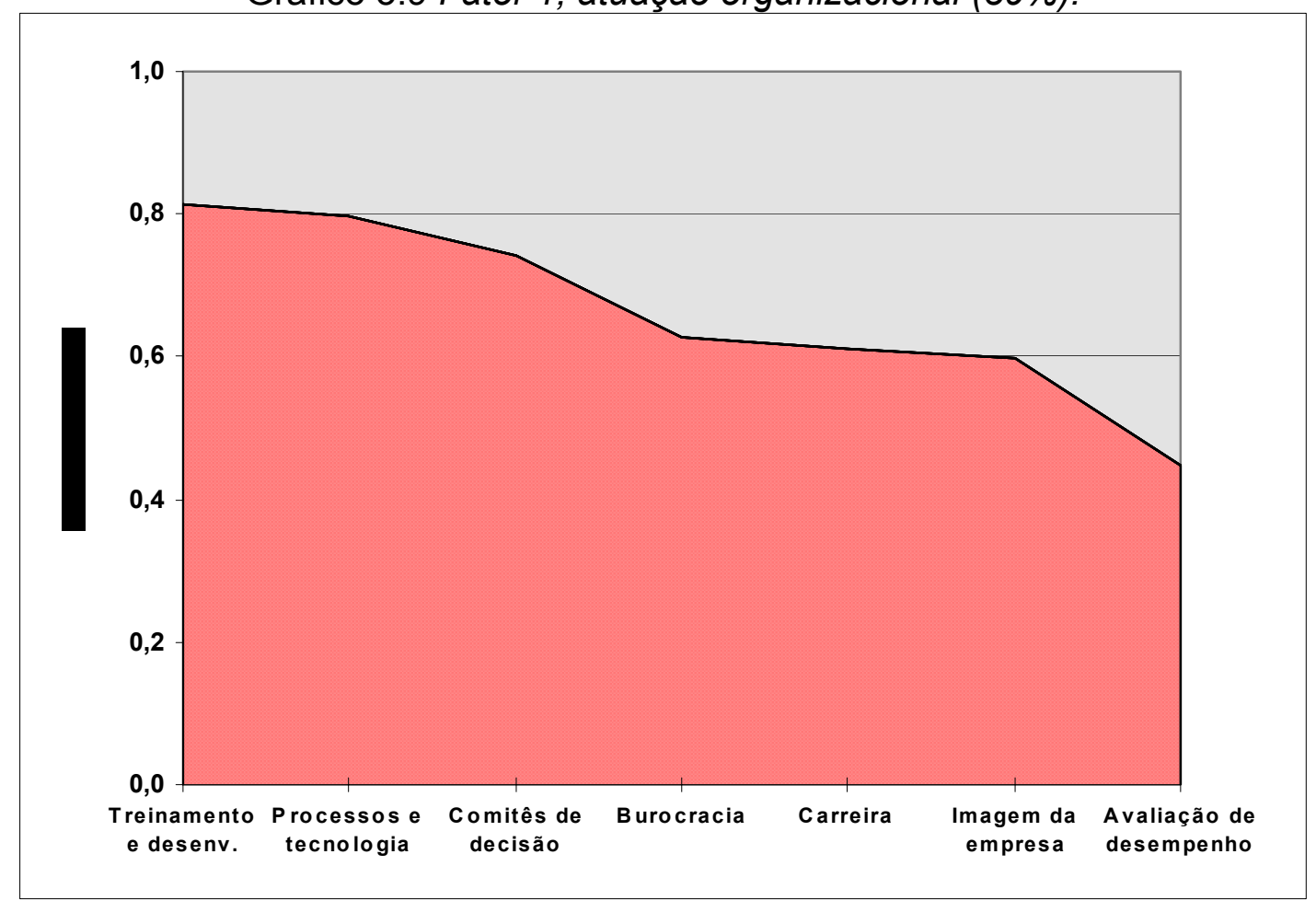

As demais variáveis do Fator 1, com menores médias, obtiveram notas não inferiores a 6 por cerca de 41 a $46 \%$ da amostra; 25 a $26 \%$ dos respondentes indicaram notas relativamente baixas (0-3) nas questões de oportunidade de participar de comitês de decisão e oportunidade de carreira. Quanto à qualidade 
de procedimentos administrativos, foi obtido o maior índice $(38.3 \%)$ de respostas nas avaliações medianas (de 4 a 6 pontos).

\subsubsection{Fator 2; necessidades biológicas}

O Fator 2, necessidades biológicas é composto por :

- EM121, SIPAT - Semana Interna de Prevenção de Acidentes.

- EM122, PPRA - Programa de Prevenção de Riscos Ambientais.

- EM128, atuação da CIPA.

- EM126, refeições oferecidas pela unidade certificada.

- EM142, atividades para o tempo livre (esportes, recreação).

O Fator 2, em que predominam variáveis do critério biológico, denominado necessidades biológicas, representa especialmente as variáveis de segurança e alimentação, conforme Fator 2, necessidades básicas.

A EM142, tempo livre/lazer, variável esta também menos explicada pela análise fatorial, obteve um percentual alto de baixas avaliações, $39 \%$ dos respondentes, se se compara com outras variáveis do fator. Obteve também a menor média de todo o conjunto de variáveis, incluindo as que formaram outros fatores. 


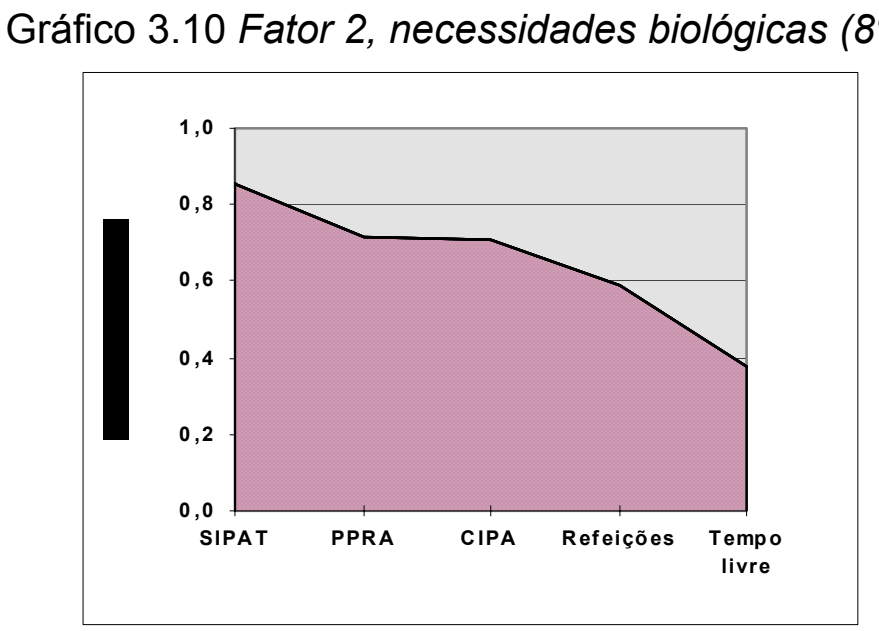

Como destaque positivo, aparece a variável EM121, SIPATs, com uma média de 6.7. Em relação às outras questões do mesmo fator, as médias variam de 6,17 a 6,58 .

O Fator 2, necessidades biológicas, reflete certa consciência prevencionista, com relação às SIPATs, associando-as às necessidades de distração e alimentação que caracterizam reposição de energias. Representam, também, o nível básico de Maslow: necessidades básicas de sobrevivência.

\subsubsection{Fator 3, inclusão social}

O Fator 3, inclusão social, constitui-se de:

- EM136, vida pessoal.

- EM133, camaradagem/clima.

- EM131, recrutamento e seleção.

- EM135, administração de salários.

- EM127, saúde - PCSMO. 
- EM116, rotinas de pessoal.

Esse fator é constituído por variáveis cujas médias são as mais altas com relação às demais questões submetidas à análise fatorial; são elas: EM133, camaradagem/clima e EM127, saúde - PCSMO, sendo as duas últimas as que possuem menor carga fatorial, pouco contribuindo para a denominação do fator. As altas médias devem-se à concentração das avaliações nos pontos mais altos da escala.

Gráfico 3.11 Fator 3: inclusão social (6\%)

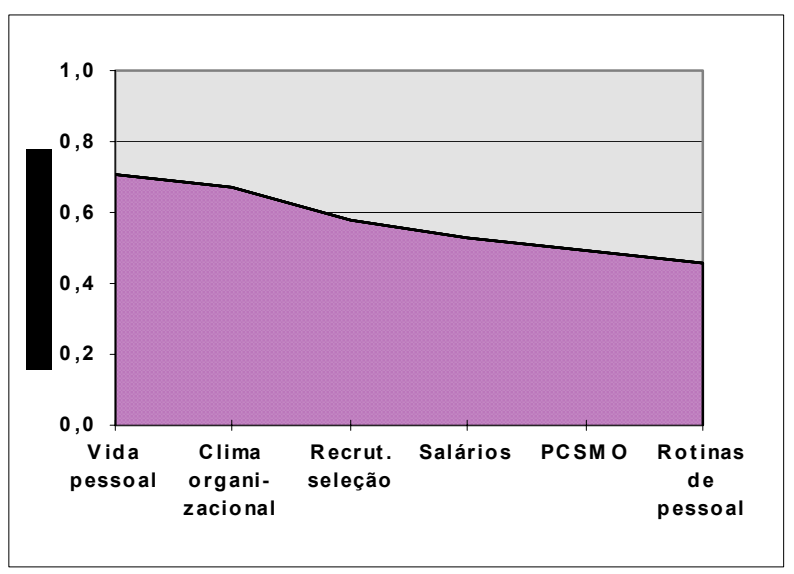

A distribuição da variável satisfação com o salário assemelha-se à distribuição de oportunidade de participar de comitês de decisão e oportunidade de carreira (pertencentes ao primeiro fator), com média relativamente baixa.

É o respeito à vida pessoal dos empregados (EM136) que possui maior carga fatorial, porém apresenta um dos menores níveis de avaliações positivas (710) do fator, destacando-se a presença de notas medianas $(34,5 \%)$, se comparado com outras variáveis. 
3.3.1.4 Fator 4, prestação de serviços

O Fator 4, prestação de serviços, é constituído das variáveis:

- EM124, convênio médico.

- EM141, convênios comerciais.

- EM123, ambulatório.

O convênio médico é muito bem avaliado por $71 \%$ dos entrevistados; em relação ao ambulatório, esse percentual cai para $62.1 \%$, comprometendo relativamente a média, já que a diferença se concentra nos níveis mais baixos de avaliação. A tendência de boa satisfação com relação ao indicador convênio médico aparece também na análise descritiva do item 3.1 e mais adiante nos clusters e estrutura de gestão, o que reafirma a importância desse indicador para a satisfação dos empregados.

Contextualizando este dado, as empresas enfrentam sérios problemas de custos de convênio médico, que são repassados para os clientes de seus produtos. Como se vive uma transição de custos médicos, este tema aparece com muita freqüência nas sugestões e citações tanto dos empregados como das gerências de recursos humanos. 
Gráfico 3.12 Composição do Fator 4, prestação de serviços (5\%).

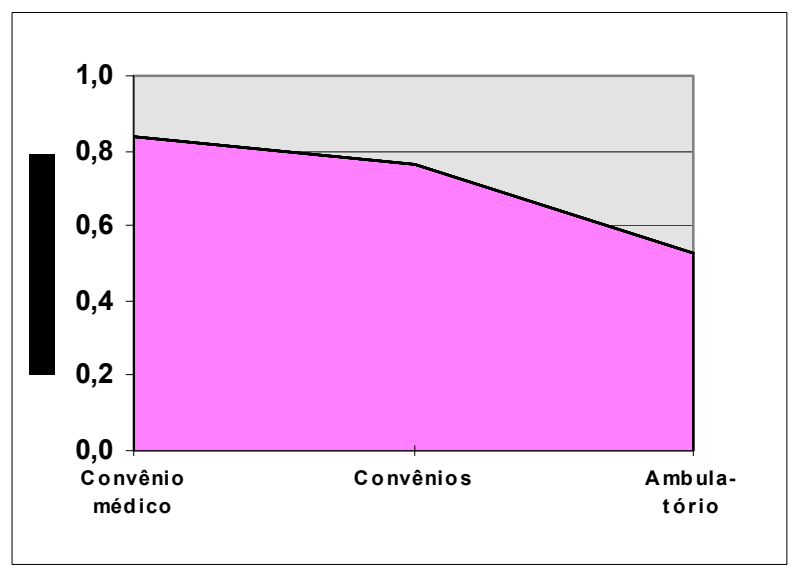

EM116, rotinas de pessoal, recebeu a maior porcentagem de notas entre 710, com $86 \%$. Sua média geral, 8,4 , também indica alta satisfação dos empregados com relação aos esforços das empresas quanto ao atendimento dos aspectos legais e burocráticos da gestão de pessoas.

A variável EM133, camaradagem/clima, obteve a segunda maior porcentagem de notas entre 7-10, e a segunda melhor média dos indicadores $(7,5)$. Pode-se concluir que os empregados sentem o companheirismo como fator de satisfação no ambiente de trabalho.

As variáveis seguintes na classificação descendente das médias das notas entre 7-10 são: EM124, convênio médico (71\%), e EM123, ambulatório (62\%), o que demonstra preocupação e satisfação moderada com os serviços de atendimento à saúde. 
Há um fato qualitativo a ser considerado: quando da visita às empresas, algumas delas, em mudanças gerenciais recentes, deixaram de pagar convênio médico, outras o restringiram aos dependentes diretos, outras pagavam-no parcialmente. Em geral, o clima não era propriamente de indignação, era de perplexidade. Talvez, de medo de futuras restrições. Quanto ao ambulatório, apesar da determinação legal, algumas empresas só ofereciam serviços de enfermaria em horários limitados. Tratava-se da minoria das empresas, mas esta característica era verbalizada como ausência de proteção à saúde, durante o trabalho.

A análise dos indicadores com menores médias ficou parcialmente comprometida pela definição não muito clara de não tem e satisfação zero, conforme comentado no início deste item. No exame dessas variáveis, o dado mais seguro refere-se à EM142, tempo livre/lazer, que recebeu $39 \%$ de respostas (entre 0-3) e média geral 4,5, demonstrando insatisfação moderada com as oportunidades e incentivos de uso das atividades de lazer. Entre as sugestões de melhorias a serem implementadas aparecem várias sugestões neste sentido.

\subsubsection{Fatores das gerências de recursos humanos}


Adotou-se para as variáveis das gerências de recursos humanos o mesmo procedimento de análise fatorial. Não se seguiu, porém, o critério de autovalores maiores que um, o que daria sete fatores, com interpretação de cada fator muito difusa. Optou-se então por analisar seis fatores, perdendo $5 \%$ de explicação de variância, mas ainda contabilizando $78 \%$ desta.

A menor taxa de explicação pelos fatores ocorreu em relação a ambulatório (43\%) e a maior (89\%) ocorreu com relação a convênio médico. Vale daí considerar que a preocupação da gerência de recursos humanos em oferecer um bom convênio médico está mais em linha com outras variáveis em questão, enquanto o esforço em termos de ambulatório tem especificidade não explicada pelo modelo.

\subsubsection{Fator 1, imagem da empresa}

O Fator 1, imagem da empresa, é composto pelos seguintes indicadores:

- RH115, ausência de burocracia.

- RH111, imagem.

- $\mathrm{RH} 116$, rotinas de pessoal.

- RH128, CIPA.

- RH122, riscos PPRA. 
Este fator apresenta combinação entre endomarketing e cumprimento legal. Embora a maior carga fatorial esteja no marketing da empresa, as maiores médias estão nas variáveis de obrigação da empresa.

Gráfico 3.13 Fator 1, imagem da empresa (36\%).

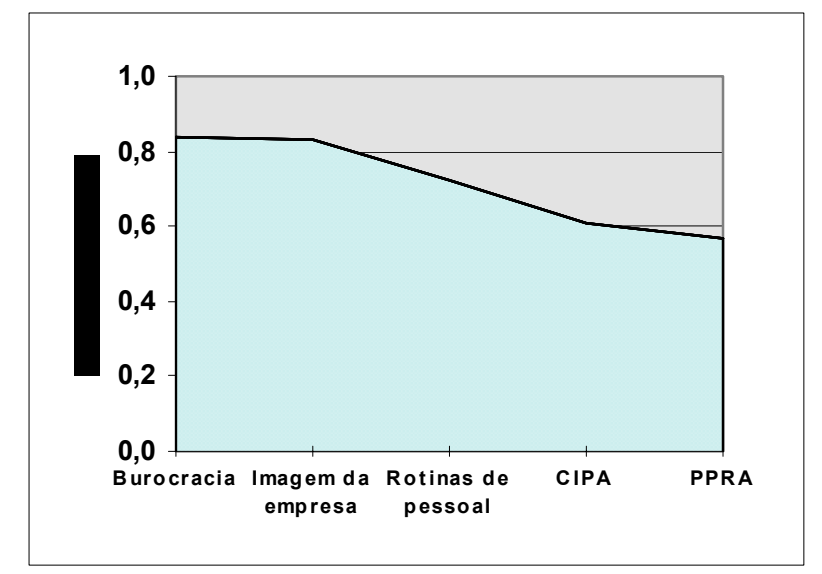

Assim, as variáveis com menores médias são as mais explicadas pela solução fatorial (RH115 e RH111).

\subsubsection{Fator 2, saúde e ética}

Este fator é constituído das seguintes variáveis:

- RH127, saúde - PCSMO.

- RH131, recrutamento e seleção.

- RH123, ambulatório.

- RH136, vida pessoal. 
O que chama mais a atenção na composição deste fator é a variável ambulatório que aparece com menor carga de notas (entre 7-10), embora em nível satisfatório.

A variável controle médico e saúde ocupacional obteve com relação ao esforço dedicado pela gerência de recursos humanos o maior índice.

A maior média, na faixa 7-10, é para o programa de saúde ocupacional. Esta é uma ação também exigida por lei, mais recente que as variáveis anteriores desta natureza. Existe muita expectativa por parte das gerências de recursos humanos com relação a este programa. Algumas já o iniciaram de forma mais ousada: combinaram o diagnóstico médico, com a contratação por exemplo do Programa Nuno Cobra, o que gerou comentários muito positivos.

Gráfico 3.14 Fator 2, saúde e ética (15\%).

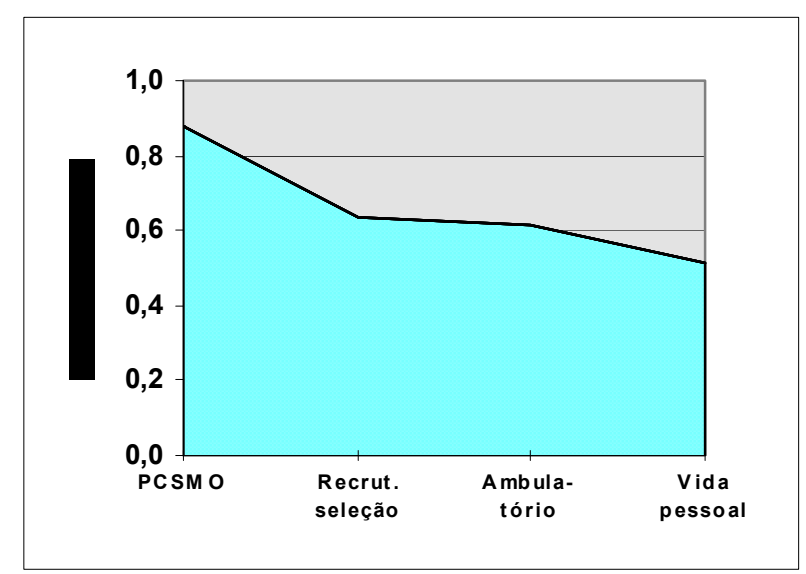




\subsubsection{Fator 3, desenvolvimento profissional}

O Fator 3, administração de recursos humanos é composto das seguintes variáveis:

- RH112, treinamento e desenvolvimento.

- RH132, avaliação do desempenho.

- RH113, processos e tecnologia.

- RH114, comitês de decisão.

O fator desenvolvimento profissional corresponde a quatro das oito questões que compõem o fator atuação organizacional.

A maior média obtida diz respeito às melhorias e processos de tecnologia, o que reflete o esforço das empresas em modernização tecnológica. A variável treinamento e desenvolvimento aparece com a segunda maior média. Provavelmente, seja um esforço associado à implantação de processos e de novas tecnologias. 
Gráfico 3.15 Fator 3, desenvolvimento profissional (8\%).

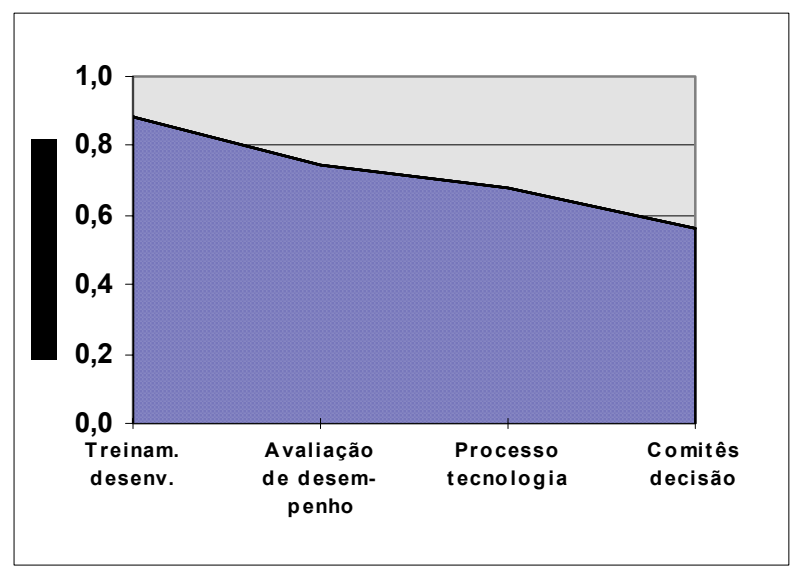

3.3.2.4 Fator 4, demandas legais

Este fator é composto pelas variáveis:

- RH121, SIPATs.

- RH141, convênios comerciais.

- RH124, convênio médico.

Convênio médico também obteve uma das médias mais elevadas quanto ao esforço do gerência de recursos humanos, além de alta comunalidade.

Há um baixo grau de rejeição a essas variáveis se se consideram as baixas porcentagens de notas entre 0-3 em todas as variáveis. Duas de suas variáveis (RH124 e RH141) correspondem a duas das três questões que formaram o quarto fator dos empregados.

A SIPAT é a variável mais familiar aos empregados e aparece com a maior porcentagem de notas medianas (entre 4-6), o que reflete a posição de esforço moderado da empresa, neste evento anual de obrigatoriedade legal. Em geral, a 
SIPAT é mais gerenciada pelas CIPAs e serviços especializados de saúde e segurança do trabalho. É nas empresas, porém, o evento de maior abrangência entre todos os níveis hierárquicos.

Gráfico 3.16 Fator 4, demandas legais (7\%).

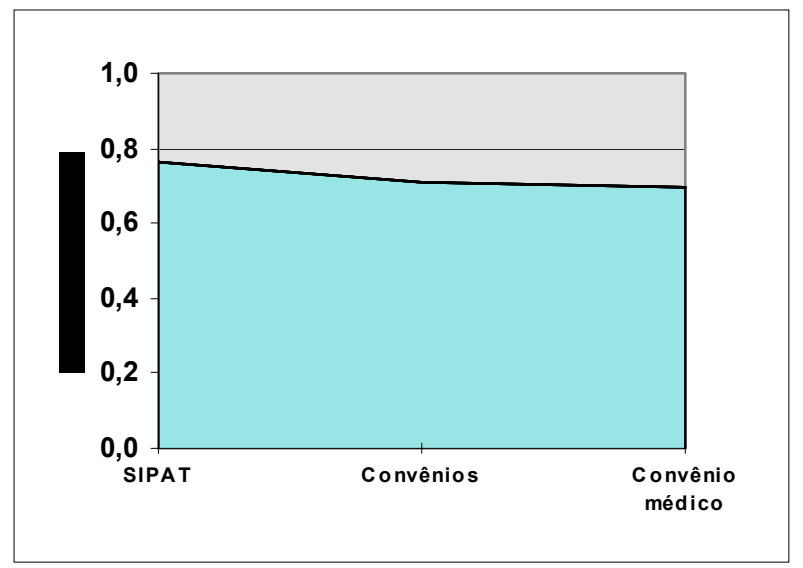

3.3.2.5 Fator 5, administração de recursos humanos

O Fator 5, administração de recursos humanos é composto pelas variáveis:

- RH133, camaradagem/clima.

- RH134, carreira.

- RH135, salário.

Este fator reuniu responsabilidades usuais da administração de recursos humanos. São variáveis muito dependentes da política superior de gestão de pessoal: clima, carreira e salários. Todas as médias são de esforço moderado, o que pode significar pouco esforço da empresa dedicado a esses fatores. 
Plano de carreira, em termos de esforço existente, recebe uma das menores médias de esforço. Esse dado é pertinente com o momento de enxugamentos e fusões vividos pelas empresas atualmente.

Salários, uma variável de importância reconhecida, aparece com esforço moderado, maior do que as expectativas geradas em torno da necessidade de sua administração. Esse dado pode não ter sido tão preciso, pois não foi perguntado sobre remuneração variável e participação de resultados mas foi citado nas sugestões de melhorias de QVT.

Gráfico 3.17 Fator 5, administração de recursos humanos (6\%).

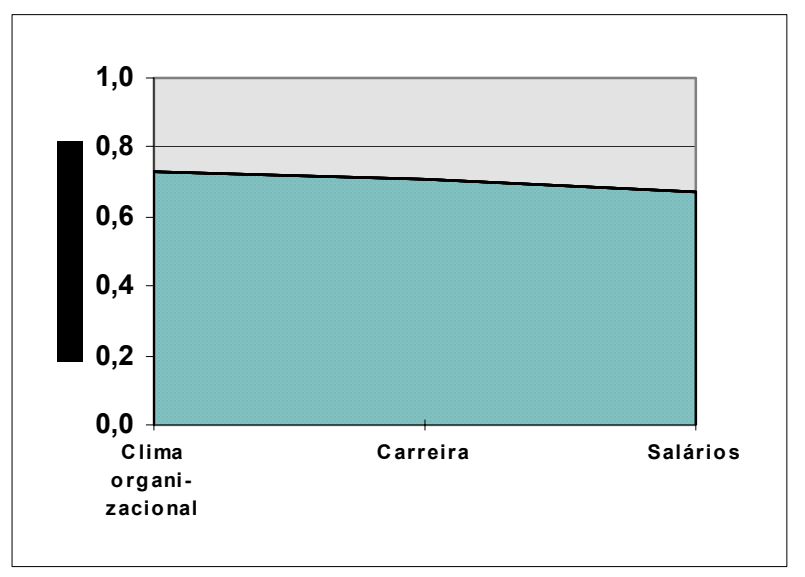

3.3.2.6 Fator 6, reposição de energias

Este fator é composto das seguintes variáveis:

- RH142, tempo livre/lazer.

- RH126, refeições. 
As variáveis que compõem este fator também estão presentes no fator relativo às necessidades biológicas dos empregados, mas aparecem isoladamente, o que chama a atenção para o espaço percebido pela empresa para melhor aproveitamento das atividades de lazer.

O esforço com refeições aparece com alta porcentagem de notas entre 7-10, o que demonstra a realidade das empresas, especialmente nos processos de terceirização dos restaurantes industriais. O resultado deste esforço nem sempre é satisfatório para os comensais. Refeições aparece no Fator 2, necessidades biológicas, com avaliações bem moderadas de satisfação (média: 6,3).

Gráfico 3.18 Composição do fator 6, reposição de energia (5\%).

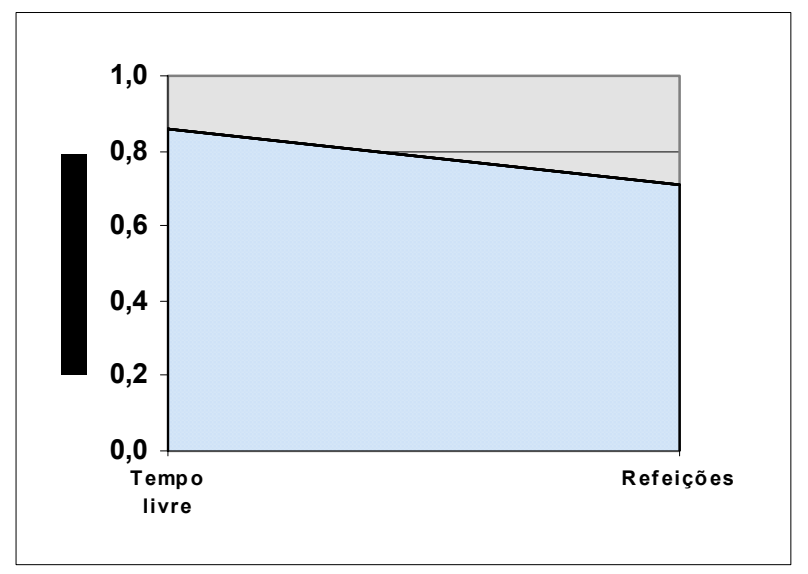

Comparando-se fatores dos empregados com os das gerências de recursos humanos, percebe-se a diferença entre as estruturas de dados: no primeiro caso, quatro fatores bastavam para explicar a variação dos dados (pelo critério de auto valor), enquanto na gerência de recursos humanos (pelo mesmo critério) são considerados sete fatores relevantes, indicando possivelmente que a forma com que as variáveis se correlacionam é distinta de um público para outro. 
Atividades programadas para o tempo livre, pouco explicada pela solução fatorial de empregados (32\%), em gerência de recursos humanos tem sua explicação elevada para $83 \%$. 


\subsection{ANÁLISE DE CONGLOMERADOS PARA O SEGMENTO DE EMPREGADOS}

Tendo em vista a segmentação dos empregados para obter as semelhanças e diferenças significativas entre eles, procedemos ao algoritmo não hierárquico da análise de conglomerados (ver Anexo 7 - Tabela SAS: Relatórios estatísticos), com base na distância euclidiana.

A entrada de dados são os escores fatoriais relativos às variações dos indicadores organizacionais, biológicos, psicológicos e sociais. A importância é atribuída pela independência entre os fatores.

A decisão sobre o número de grupos foi feita com o apoio de um dendograma, com as saídas estatísticas do procedimento anterior.

Para análise dos resultados dos empregados foi utilizada a análise de conglomerados, também denominados clusters.

Foram obtidos três tipos de perfis denominamos Perfil 1, realizados, Perfil 2, desconfiados, Perfil 3, críticos, constituídos por:1 realizados em quase metade da amostra (49\%), críticos em mais de um terço (39\%) e desconfiados, a minoria $(12 \%)$ 
Gráfico 3.19 Perfis dos empregados.

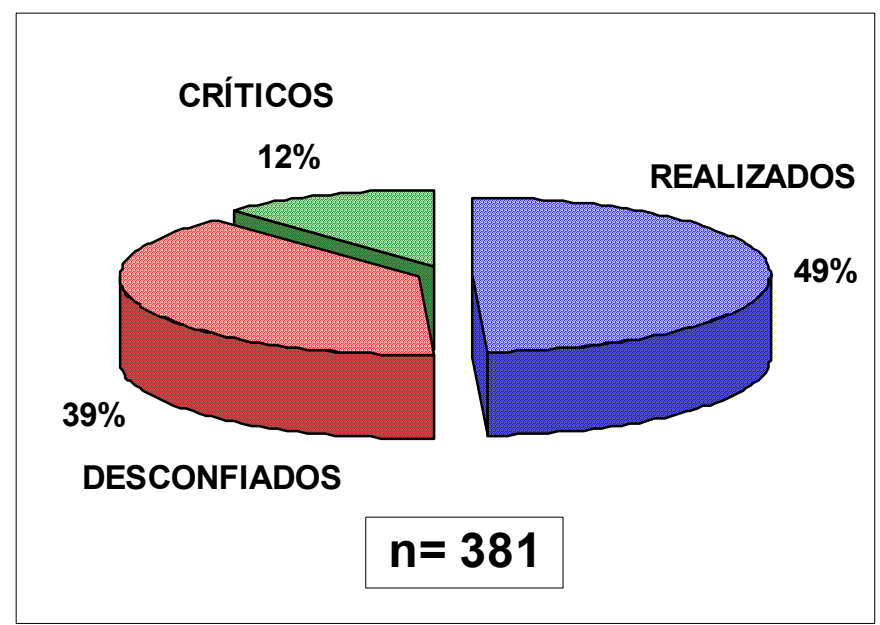

O "batismo" dos perfis foi idealizado com base na ênfase dos conglomerados. Com os tratamentos e as provas estatísticas indicados na Quadro 2.8, pode-se segmentar a amostra em três conglomerados, com base na distribuição dos indicadores detalhados na Tabela 3.11.

Esses perfis foram obtidos por meio da análise de variância, para tamanho de caselas desiguais e posterior comparação múltipla mediante o método de Tukey, além da prova do Qui-quadrado. Estabeleceu-se como variável dependente a avaliação dos empregados, e como independente, o conglometado. 
Tabela 3.11 Composição dos perfirs dos empregados.

\begin{tabular}{|c|c|c|c|c|c|c|}
\hline Variáveis & $P$ value & \multicolumn{2}{|c|}{ realizados } & desconfiados & \multicolumn{2}{|c|}{ críticos } \\
\hline EM111 & 0.000 & 7.59 & $(\mathrm{CL} 2, \mathrm{CL} 3)$ & 6.43 & 6.30 & \\
\hline EM112 & 0.000 & 7.34 & (CL2,CL3) & $6.04 \quad(\mathrm{CL} 3)$ & 4.30 & \\
\hline EM113 & 0.000 & 7.30 & $(\mathrm{CL} 2, \mathrm{CL} 3)$ & $6.37 \quad(\mathrm{CL} 3)$ & 4.48 & \\
\hline EM114 & 0.000 & 6.12 & $(\mathrm{CL} 2, \mathrm{CL} 3)$ & $4.83 \quad(\mathrm{CL} 3)$ & 3.43 & \\
\hline EM115 & 0.000 & 6.55 & $(\mathrm{CL} 2, \mathrm{CL} 3)$ & $5.46 \quad(\mathrm{CL} 3)$ & 4.68 & \\
\hline EM116 & 0.000 & 8.73 & $(\mathrm{CL} 2)$ & 7.72 & 8.77 & $(\mathrm{CL} 2)$ \\
\hline EM121 & 0.000 & 5.99 & & $7.15 \quad$ (CL1) & 8.00 & $(\mathrm{CL} 1)$ \\
\hline EM122 & 0.072 & 6.43 & & 6.48 & 7.43 & \\
\hline EM123 & 0.013 & 6.59 & (CL3) & $6.74 \quad(\mathrm{CL} 3)$ & 5.09 & \\
\hline EM124 & 0.000 & 7.80 & (CL3) & $7.44 \quad(C L 3)$ & 5.09 & \\
\hline EM125 & 0.058 & 2.67 & & 2.66 & 1.39 & \\
\hline EM126 & 0.033 & 5.91 & & $6.74 \quad(\mathrm{CL} 1)$ & 5.93 & \\
\hline EM127 & 0.000 & 8.08 & $(\mathrm{CL} 2, \mathrm{CL} 3)$ & 6.64 & 6.84 & \\
\hline EM128 & 0.400 & 6.07 & & 6.01 & 6.64 & \\
\hline EM131 & 0.000 & 7.43 & $(\mathrm{CL} 2)$ & 5.91 & 7.27 & $(\mathrm{CL} 2)$ \\
\hline EM132 & 0.000 & 7.11 & $(\mathrm{CL} 2, \mathrm{CL} 3)$ & 5.69 & 6.18 & \\
\hline EM133 & 0.000 & 8.50 & $(\mathrm{CL} 2, \mathrm{CL} 3)$ & 6.35 & 7.70 & $(\mathrm{CL} 2)$ \\
\hline EM134 & 0.000 & 6.75 & $(\mathrm{CL} 2, \mathrm{CL} 3)$ & $4.59 \quad(C L 3)$ & 3.36 & \\
\hline EM135 & 0.000 & 6.59 & $(\mathrm{CL} 2, \mathrm{CL} 3)$ & 4.16 & 4.84 & \\
\hline EM136 & 0.000 & 7.42 & (CL2) & 4.55 & 7.36 & $(\mathrm{CL} 2)$ \\
\hline EM141 & 0.001 & 6.26 & $(\mathrm{CL} 3)$ & $6.10 \quad(\mathrm{CL} 3)$ & 4.25 & \\
\hline EM142 & 0.212 & 4.52 & & 4.53 & 3.57 & \\
\hline EM143 & 0.269 & 2.55 & & 2.42 & 1.66 & \\
\hline EM144 & 0.013 & 3.20 & (CL3) & 2.35 & 1.66 & \\
\hline EM145 & 0.001 & 5.20 & (CL3) & (CL3) & 2.57 & \\
\hline EM146 & 0.026 & 3.83 & $(\mathrm{CL} 3)$ & 3.01 & 2.45 & \\
\hline EM211 & 0.000 & 7.90 & $(\mathrm{CL} 2, \mathrm{CL} 3)$ & 6.54 & 6.70 & \\
\hline EM212 & 0.000 & 6.56 & $(\mathrm{CL} 2, \mathrm{CL} 3)$ & 5.59 & 5.64 & \\
\hline EM213 & 0.000 & 7.51 & $(\mathrm{CL} 2, \mathrm{CL} 3)$ & 6.39 & 6.18 & \\
\hline EM214 & 0.000 & 6.61 & (CL2,CL3) & $5.39 \quad(\mathrm{CL} 3)$ & 4.57 & \\
\hline EM215 & 0.000 & 8.37 & (CL2,CL3) & 7.68 & 7.39 & \\
\hline Idade & 0.089 & 36.9 & & 34.7 & 34.6 & \\
\hline
\end{tabular}


No Tabela 3.11, encontram-se, entre parênteses, os conglomerados cujas médias são significativamente inferiores aos conglomerados da coluna correspondente.

Os conglomerados sinalizam alguns perfis típicos das atitudes dos empregados com relação à satisfação das ações e dos programas de qualidade de vida no trabalho desenvolvidos pela totalidade de unidades certificadas.

Considerou-se, para a análise da variância, assim como para o teste do QuiQuadrado, nível de significância de 5\%.

As únicas variáveis nominais que não puderam ser consideradas independentes dos conglomerados foram: nível hierárquico, convênio médico e ambulatório.

Os percentuais relativos a ausência de acidentes, amizade e investimento são semelhantes, enquanto os relativos a confiança, humanismo e paz são discrepantes.

Pessoas realizadas apresentam combinação de aspectos sociais: suas maiores porcentagens de escolha, comparando-se com os outros perfis, são humanismo, amor e realização pessoal e menor ênfase em paz.

Profissionais desconfiados escolheram com maior freqüência competitividade, e com menos frequência, responsabilidade e amor.

Os críticos escolheram mais paz, responsabilidade e segurança. 


\subsubsection{Detalhamento dos perfis}

a Perfil 1 , realizado

É o segmento com melhores avaliações, se comparado aos demais. Suas notas, em média, só são significativamente inferiores aos dois outros segmentos em relação à SIPAT.

Gráfico 3.20 Perfil 1, realizados.

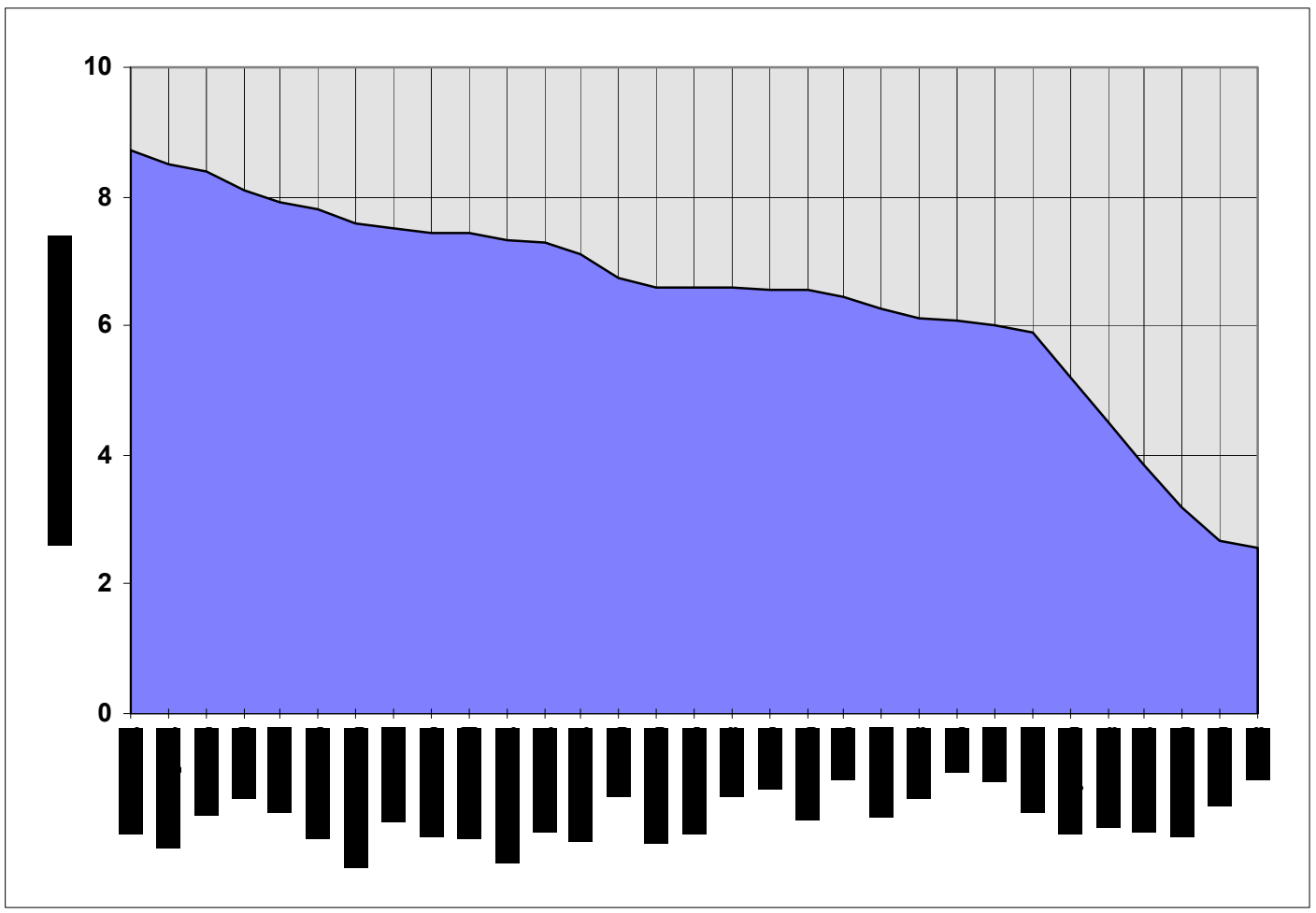

Em termos hierárquicos, o perfil realizado é mais encontrável no nível de supervisão, porém não se pode afirmar nada em relação à faixa salarial comparativamente aos outros conglomerados. 
Denomina-se esse segmento de aparentemente realizados.

b) Perfil 2, desconfiados

Quanto à avaliação da qualidade de vida no trabalho, esse conglomerado apresenta comportamento independentemente em relação ao esforço da gerência de recursos humanos, com exceção do comportamento relativo a refeições oferecidas pela unidade certificada e SIPAT, variáveis estas com melhores avaliações aqui, 'desconfiados', talvez evitando tecer alguma opinião sobre os serviços da unidade certificada.

Gráfico 3.21 Perfil 2, desconfiados.

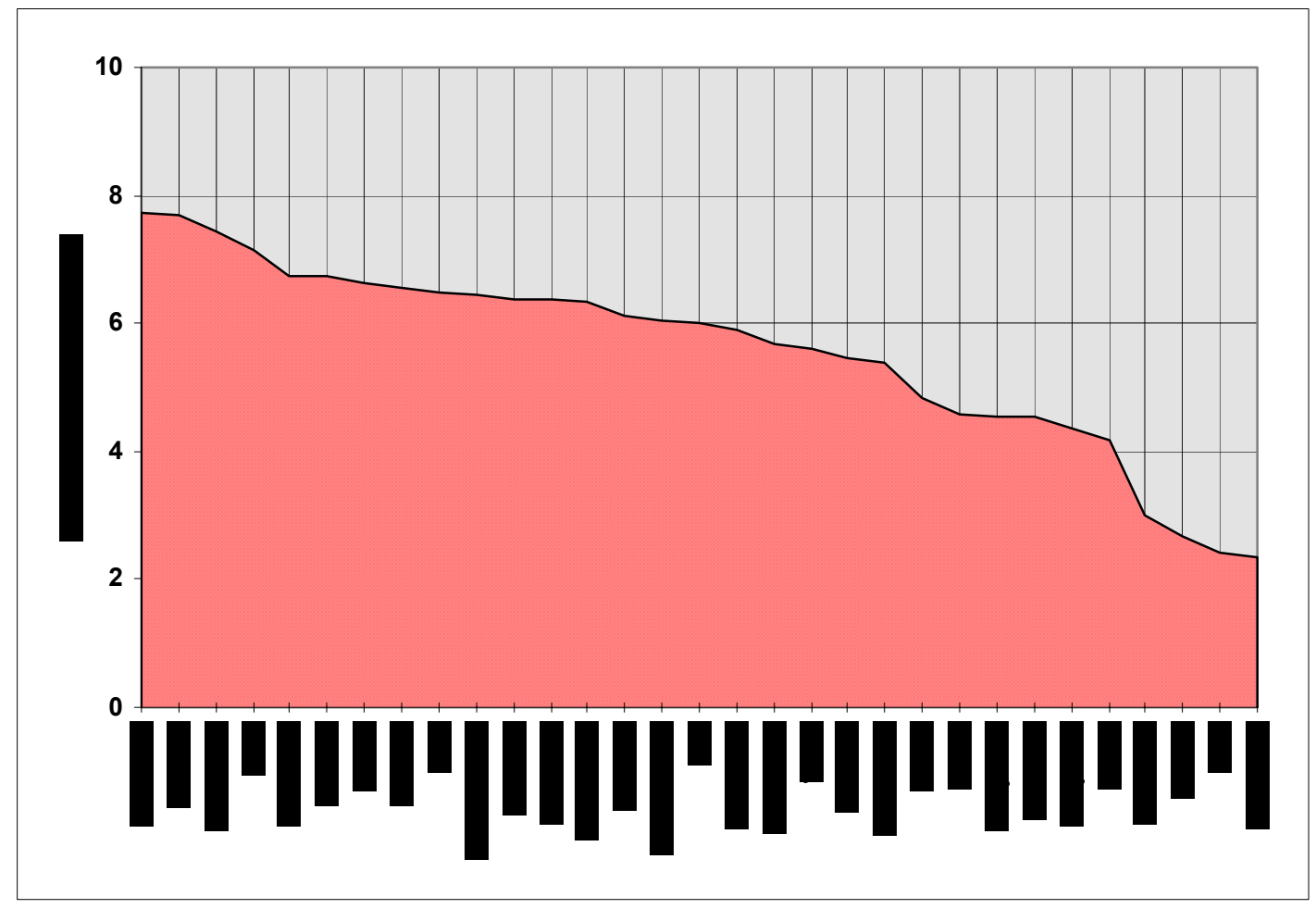

A composição desse perfil apresenta maior crítica em relação às rotinas de pessoal, critérios de recrutamento e seleção, respeito à vida pessoal dos empregados. É o grupo que relatou mais ocorrências de saúde-doença. 
Caracteriza-se pelo maior número de internações hospitalares, utilização do convênio médico ou serviço de saúde da unidade certificada. Talvez, estressado porque nesse segmento, comparando-se com os demais, a gerência, como nível hierárquico, está mais presente.

c Perfil 3, críticos

Nesse segmento, encontram-se, em geral, as menores notas médias, em comparação com os demais conglomerados. São empregados mais característicos da produção, e talvez mais críticos ou sinceros em relação às ações e programas de qualidade de vida no trabalho.

Gráfico 3.22 Perfil 3, críticos.

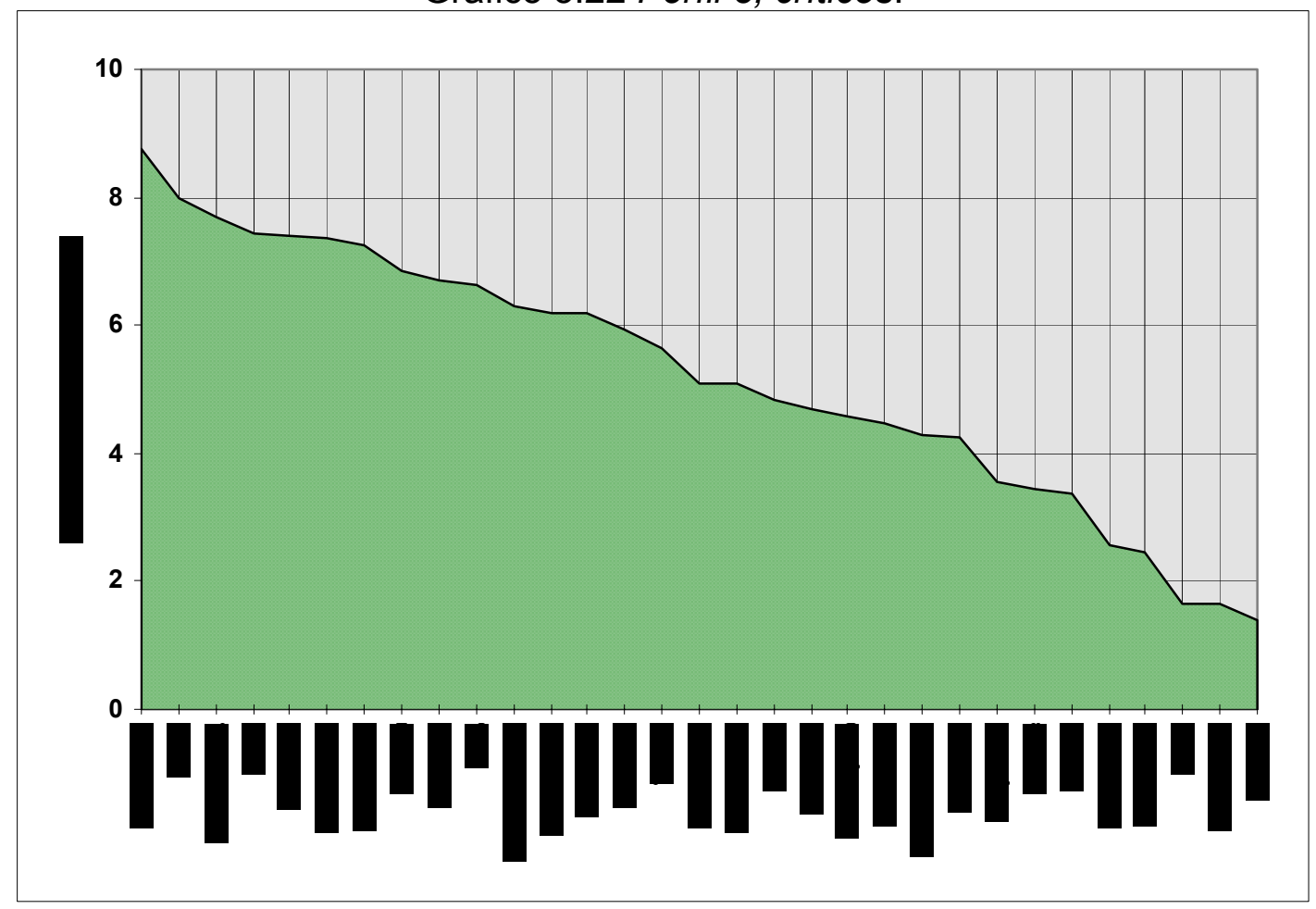




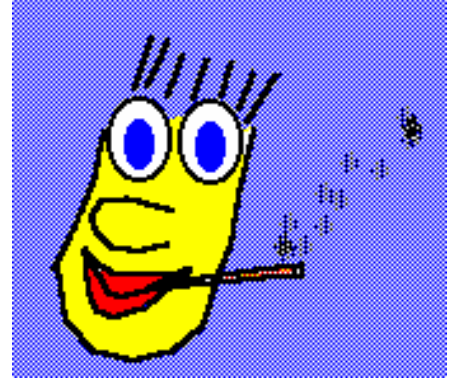

REALIZADOS

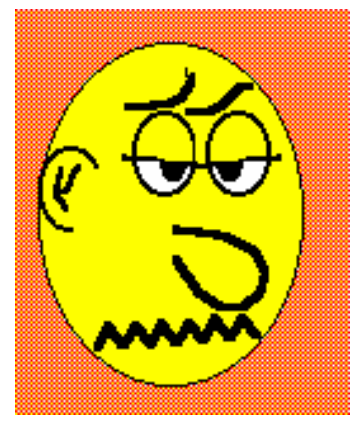

DESCONFIADOS
- Politicamente corretos

- Têm uma imagem positiva da empresa

- Estão satisfeitos com processos e tecnologia

- Relacionam positivamente qualidade de vida com resultados positivos
- Estão menos satisfeitos com as SIPATs e com controle de riscos ocupacionais

- Estão muito satisfeitos com o clima de camaradagem
- São os mais satisfeitos com as refeições, embora moderadamente

- Atribuiram menores notas de satisfação para rotinas de pessoal e critérios de recrutamento e seleção

- Insatisfeitos com salário
- São cuidadosos para se expressar

- Alcançaram a menor média para os programas de saúde e de segurança

- Moderados quanto à satisfação / insatisfação ambulatorial e convênios

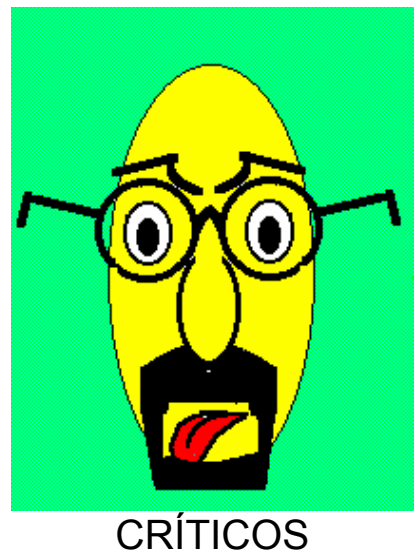

- Satisfeitos com a privacidade pessoal

- Insatisfeitos com convênios comerciais, atividades de lazer $\mathrm{e}$ financiamento de cursos externos (demandas sociais)

\footnotetext{
Figura 3.3 Perfis dos empregados
}

- Têm problemas com a alimentação da empresa e ambulatório

- Insatisfeitos com as oportunidades de treinamento e de desenvolvimento

- Insatisfeitos com os processos de trabalho e tecnologias

- Demonstram insatisfação com a participação nos comitês de decisão 


\subsubsection{Sexo}

Considerando a variável sexo, a pesquisa constatou homogeneidade de distribuição de homens e mulheres em todos os perfis. Como as muheres aparecem um pouco menos no perfil 1: realizados, esta diferença pode dar indícios que as mulheres estão um pouco menos realizadas do que desconfiadas ou críticas nas ações de qualidade de vida.

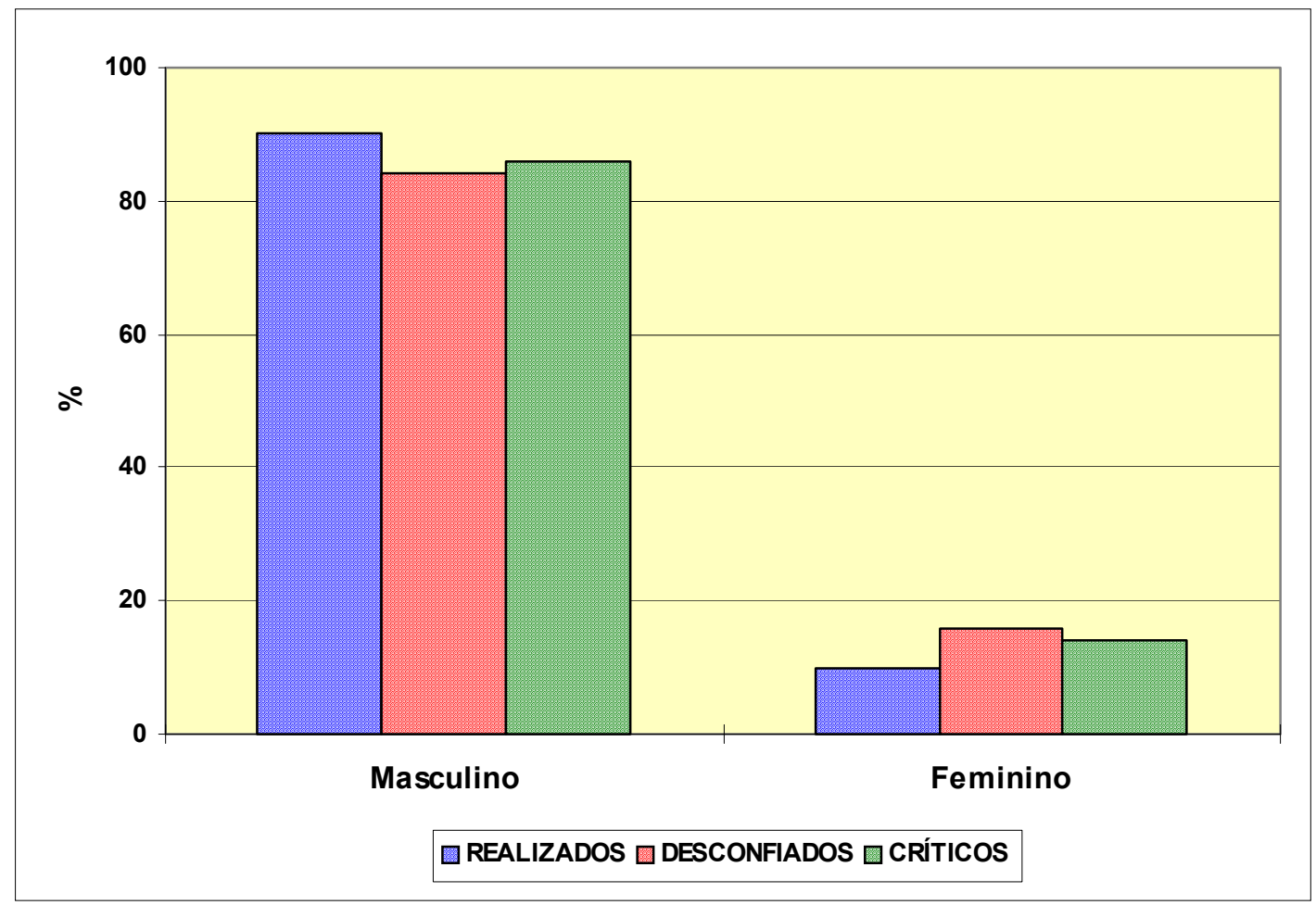

Gráfico 3.23 Sexo 


\subsubsection{Nível hierárquico}

A comparação dos níveis hierárquicos no Gráfico 3.24 mostra-nos o maior número de críticos na produção (73\%). Já a supervisão aparece com maior percentagem de realizados. A gerência aparece com percentagem maior no perfil desconfiados.

Associando esses índicios aos compromissos dos cargos pode-se concluir que os supervisores se mostram mais receptivos às ações de QVT, enuqanto os gerentes, que representam a ligação entre o nível operacional e o estratégico, mostram indícios de maior desconfiança.

\section{Gráfico 3.24 Níveis hierárquicos}

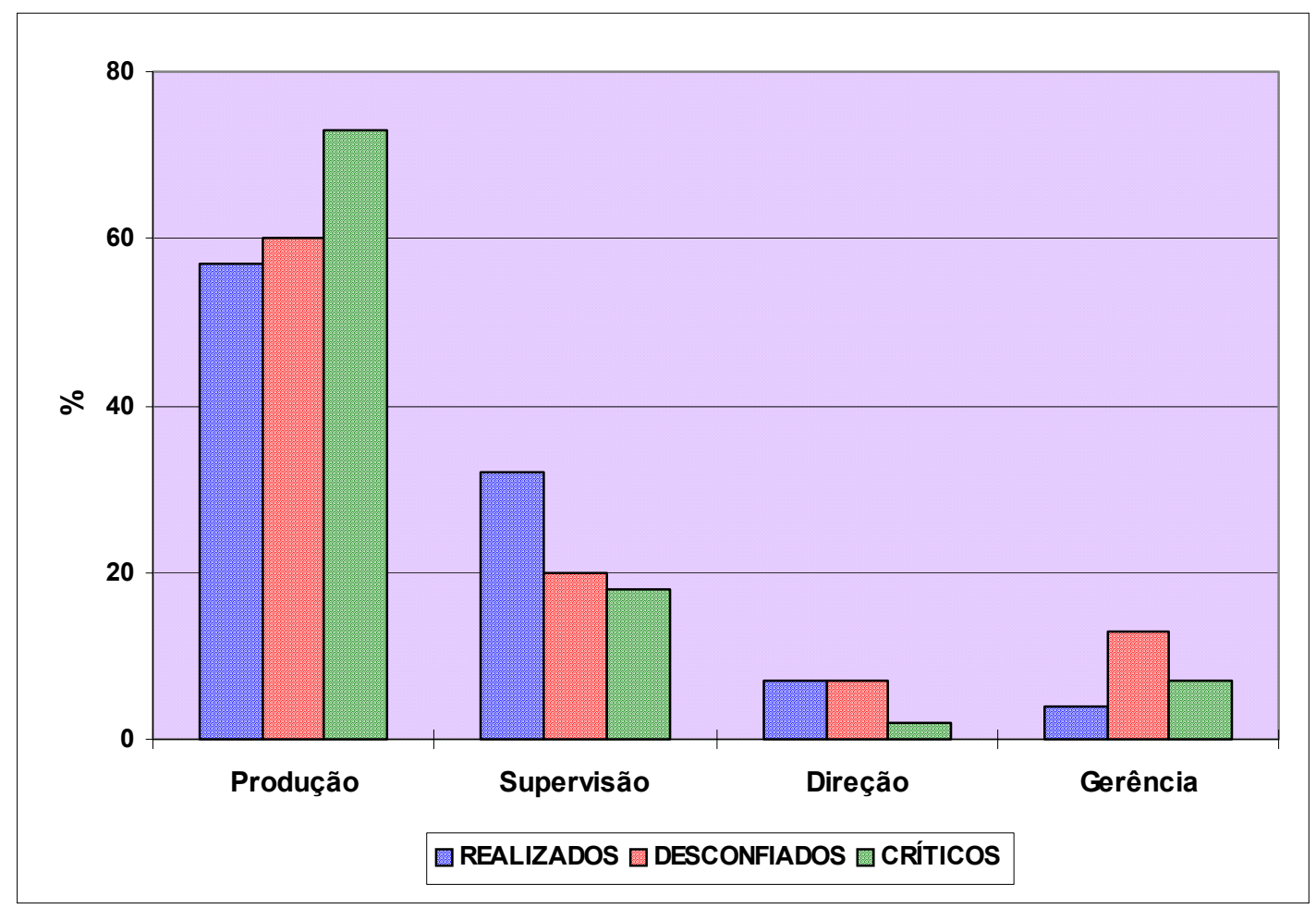




\subsubsection{Faixa salarial}

O salário não é diferenciado do perfil. Há uma tendência maior de salários entre $R \$ 500,00-R \$ 1.000,00$ em relação ao perfil 2, desconfiados. A faixa em que há maior concentração de perfis realizados e críticos é a de $R \$ 1.001,00$ a $R \$$ $3.000,00$.

Gráfico 3.25 Faixa salarial.

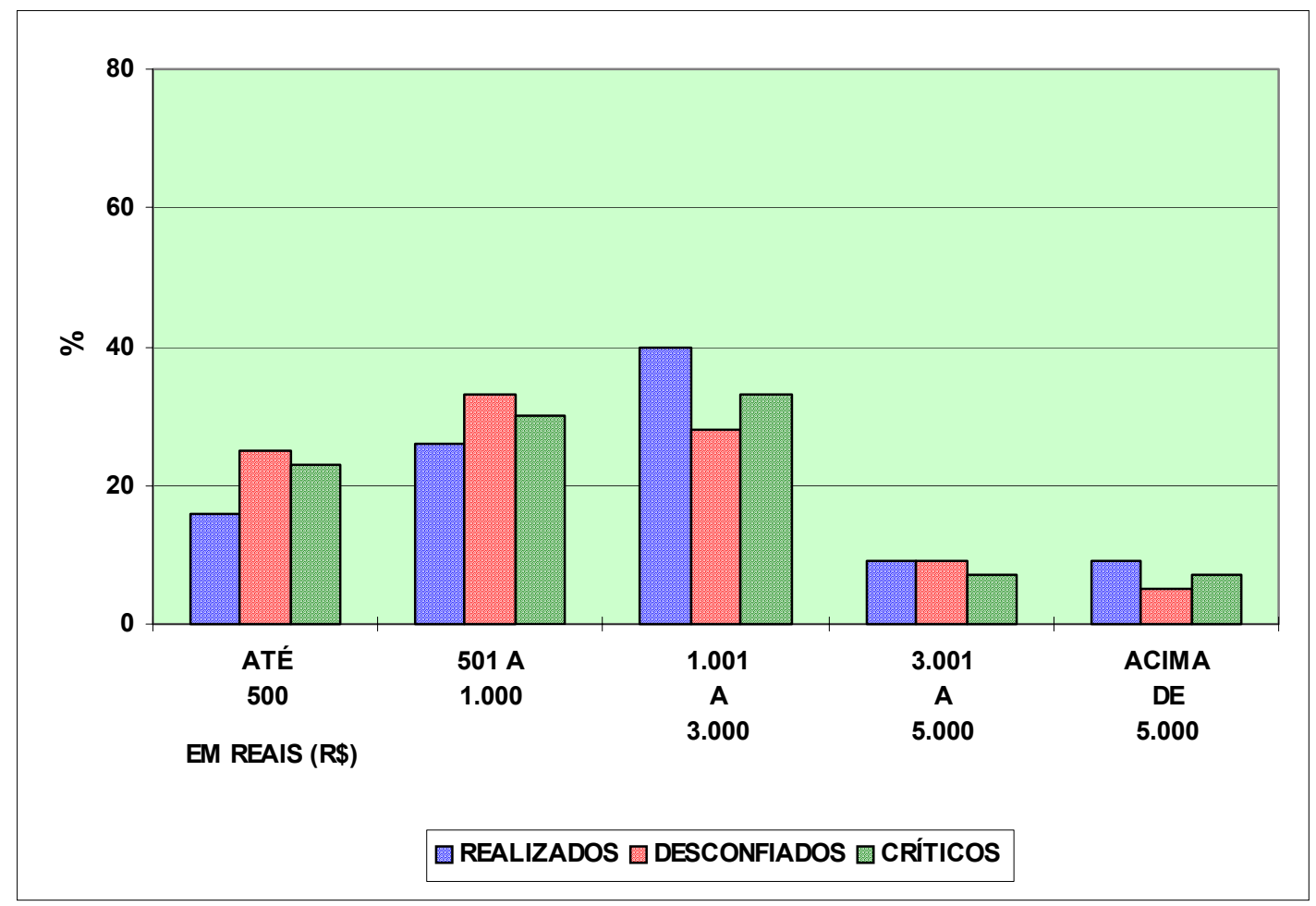

\subsubsection{Escolaridade}

Com relação à escolaridade, há maior incidência de todos os perfis na faixa de até $2^{\circ}$ grau.

Na faixa de faculdade incompleta, aparece maior número de críticos, talvez porque estejam vivendo em ambiente universitário. 
$\mathrm{Na}$ faixa de escolaridade até $8^{\mathrm{a}}$ série encontramos a distribuição mais heterogênea. Há maior porcentagem de desconfiados e menor de críticos. A relação que pode ser pensada são os diferentes contextos sociais que levaram este pessoal, com idade de ter concluído um curso universitário, de não ter atingido em $01^{\circ}$ grau. No entanto, as empresas que buscam certificação necessitam que seu pessoal tenha escolaridade em nível de $1^{\circ} \mathrm{grau}$.

As distribuição dos perfis no número de dependentes é variada em todas as escalas. Perfis de realizados e críticos aparecem com maior porcentagem na faixa 3 , dependentes. Há maior concentração de empregados nas faixas nenhum

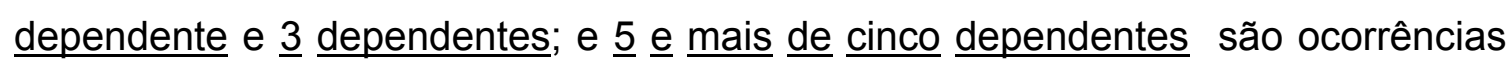
percentuais bem menores.

Portanto, os dependentes (provavelmente familiares) tendem a ser pouco numerosos, e nenhum dependente é uma faixa significativa.

Gráfico 3.26 Escolaridade.

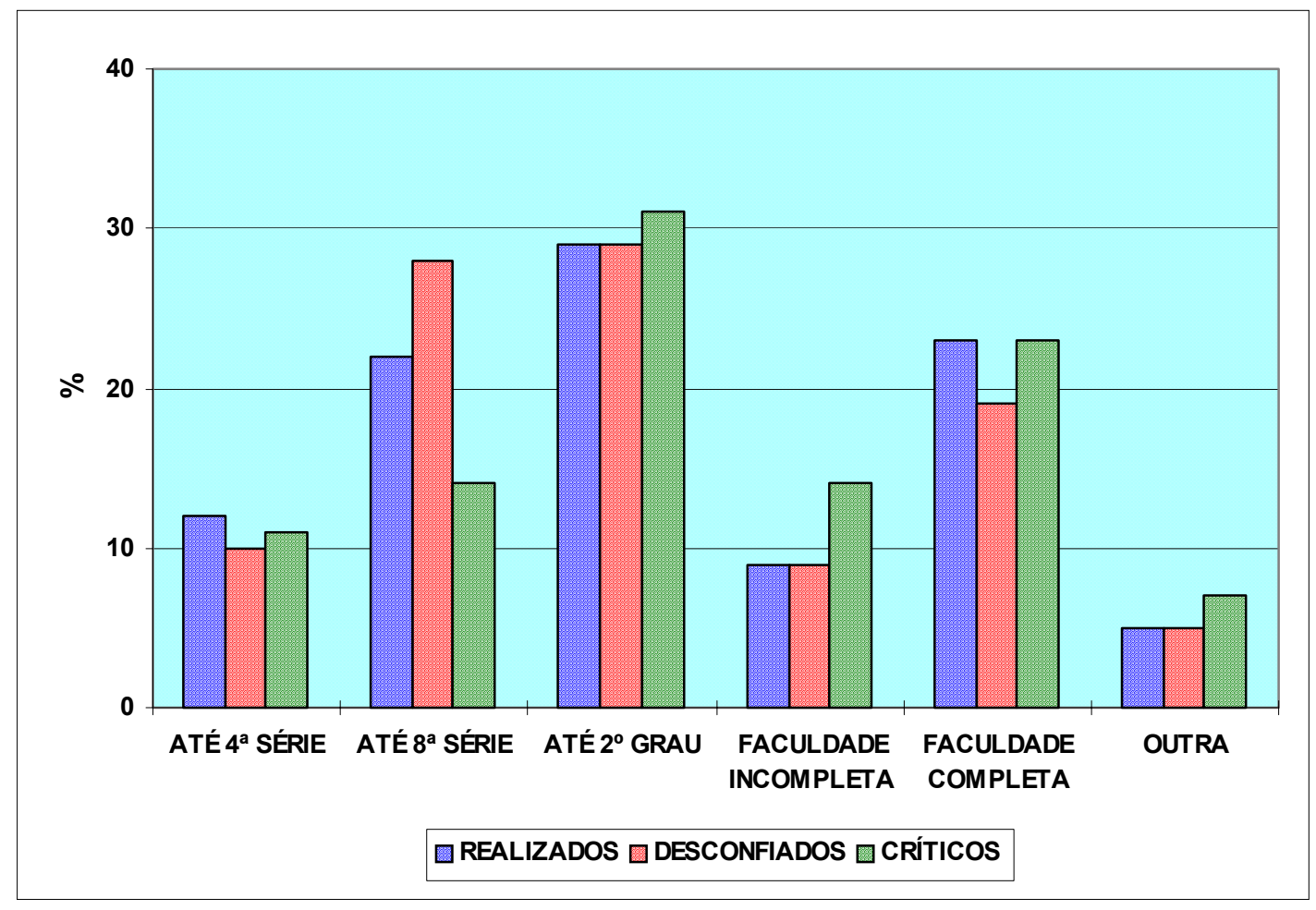


Considerações: as únicas variáveis nominais que podem ser consideradas dependentes dos conglomerados são: nível hierárquico, utilização de convênio médico, utilização de serviço de saúde da unidade certificada.

\subsubsection{Número de dependentes}

Gráfico 3.27 Número de dependentes.

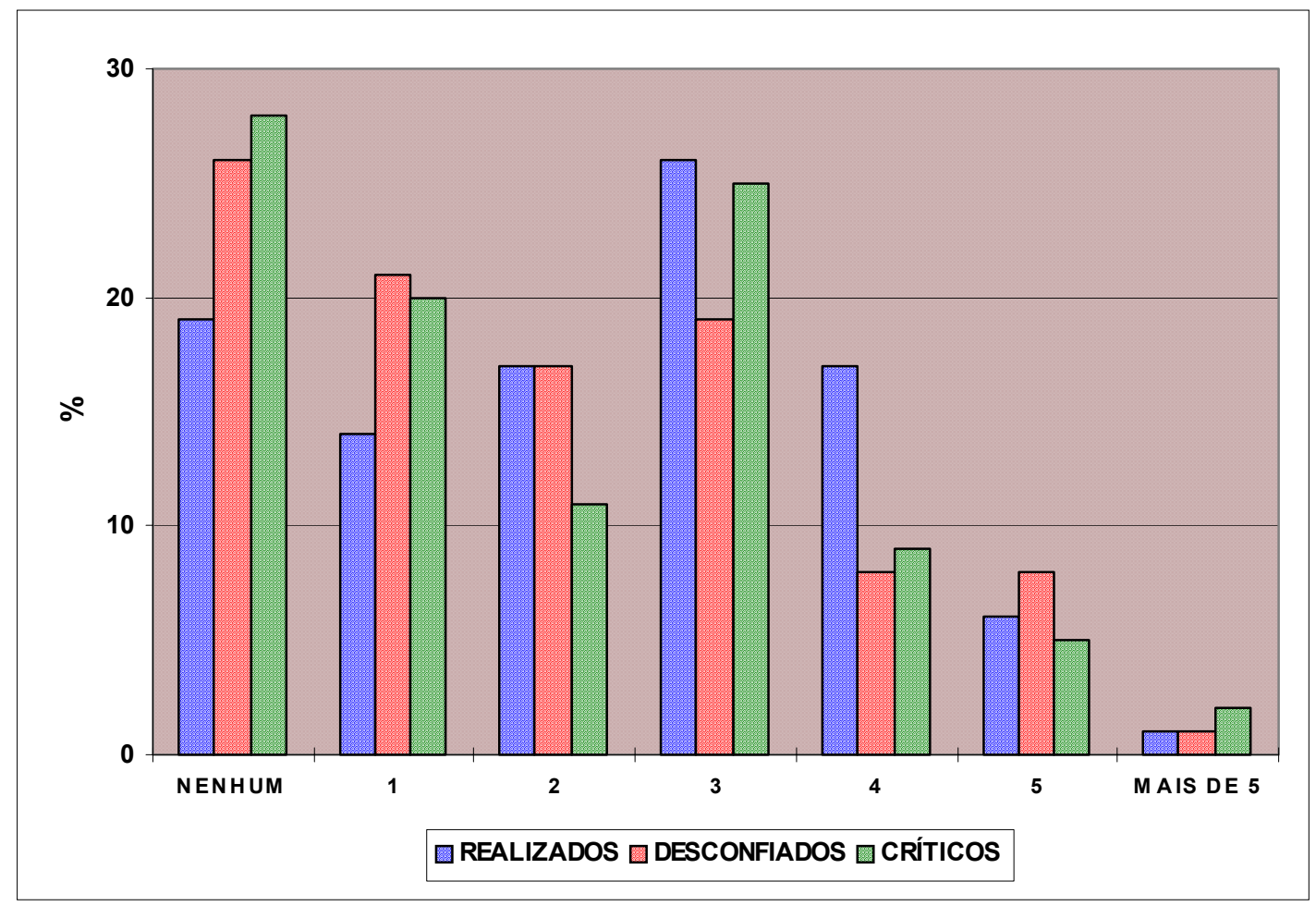

3.4.2.6 Variáveis excluídas da análise de conglomerados

As variáveis excluídas foram: oportunidade de praticar ginástica no trabalho, atendimento aos filhos (143), cesta básica (144), qualidade dos seguros da previdência privada(145), financiamento para cursos externos (146). 
Para aprofundar a compreensão do comportamento das variáveis dos conglomerados que apresentavam notas zero, com alta freqüência (que também tinham o significado de não tem), foi aplicada a prova do Qui-Quadrado, com os dados da Tabela 3.12 .

Tabela 3.12:Dados para a análise da prova do Qui-quadrado.

\begin{tabular}{|c|c|c|c|}
\hline Tipo de resposta & $\begin{array}{c}\text { Conglomerado 1: } \\
\text { Realizados }\end{array}$ & $\begin{array}{c}\text { Conglomerado 2: } \\
\text { desconfiados }\end{array}$ & $\begin{array}{c}\text { Conglomerado 3: } \\
\text { críticos }\end{array}$ \\
\hline
\end{tabular}

\begin{tabular}{|r|c|c|c|}
\hline \multicolumn{2}{|c|}{ EM 125: Oportunidade de práticar ginástica no trabalho: $p=0,27$} \\
\hline Sim & 44 & 45 & 33 \\
\hline Não & 56 & 55 & 69 \\
\hline$\%$ total & 100 & 100 & 100 \\
\hline
\end{tabular}

\begin{tabular}{|r|c|c|c|}
\hline \multicolumn{2}{|c|}{ EM 143: Atendimento aos filhos: $p=0,503$} \\
\hline Sim & 40 & 45 & 36 \\
\hline Não & 60 & 55 & 64 \\
\hline$\%$ total & 100 & 100 & 100 \\
\hline
\end{tabular}

\begin{tabular}{|r|c|c|c|}
\hline \multicolumn{2}{|c|}{ EM 144: Cesta básica: $p=0,02$} & \\
\hline Sim & 47 & 37 & 25 \\
\hline Não & 53 & 63 & 75 \\
\hline \% total & 100 & 100 & 100 \\
\hline
\end{tabular}

\begin{tabular}{|c|c|c|c|}
\hline \multicolumn{3}{|c|}{ EM 145: Qualidade dos seguros da previdência privada: $p=0,00$} \\
\hline Sim & 44 & 45 & 33 \\
\hline Não & 56 & 55 & 69 \\
\hline \% total & 100 & 100 & 100 \\
\hline
\end{tabular}

\begin{tabular}{|c|c|c|c|}
\hline \multicolumn{3}{|c|}{ EM 146: Financiamento para cursos externos: $p=0,21$} \\
\hline Sim & 56 & 53 & 41 \\
\hline Não & 44 & 47 & 59 \\
\hline \% total & 100 & 100 & 100 \\
\hline
\end{tabular}


Rejeita-se a hipótese de independência entre conglomerados e fornecimento de cesta básica $(p=0,002)$ e qualidade dos seguros de previdência privada $(p=$ 0,000). Os empregados do conglomerado 1, realizados, são os que mais apontam a existência da cesta básica, caindo este percentual para o conglomerado 2, desconfiados, acentuando-se a redução do percentual no conglomerado 3, críticos. Na variável qualidade dos seguros de previdência privada, os conglomerados realizados e desconfiados apresentam o mesmo porcentual de respostas, caindo quase a metade no conglomerado 3, críticos. A prova do quiquadrado deu resultado não significativo: $\alpha=0,05$. $E$, na variável $E M \quad 146$, financiamento para cursos externos, os conglomerados comportaram-se da mesma forma. Os resultados demonstraram que não existe diferença entre os conglomerados com relação a estas variáveis.

\subsubsection{Ocorrência de doença}

Os sinais clínicos são sempre um forte sinalizador do estado de tensão e condições de saúde das pessoas, como foi dito no item 3.2.6. Neste aspecto, o que se observa de diferenciador entre os perfis é que os desconfiados apresentraram maiores porcentagens de uso do convênio médico, ambulatório e faltas ao trabalho do que os demais, o que pode indicar tendência de maior tensão no trabalho.

O uso de remédios específicos, além de reproduzir um hábito cultural típico dos brasileiros, pode indicar busca de autocontrole, uma vez que neste perfil os outros tipos de ocorrências médicas não são significativos. 
O perfil 1, realizado, apresenta porcentagens medianas em relação ao uso de hospitais e do ambulatório. Estes dados podem indicar moderado nível de tensão e controle do estilo de vida.

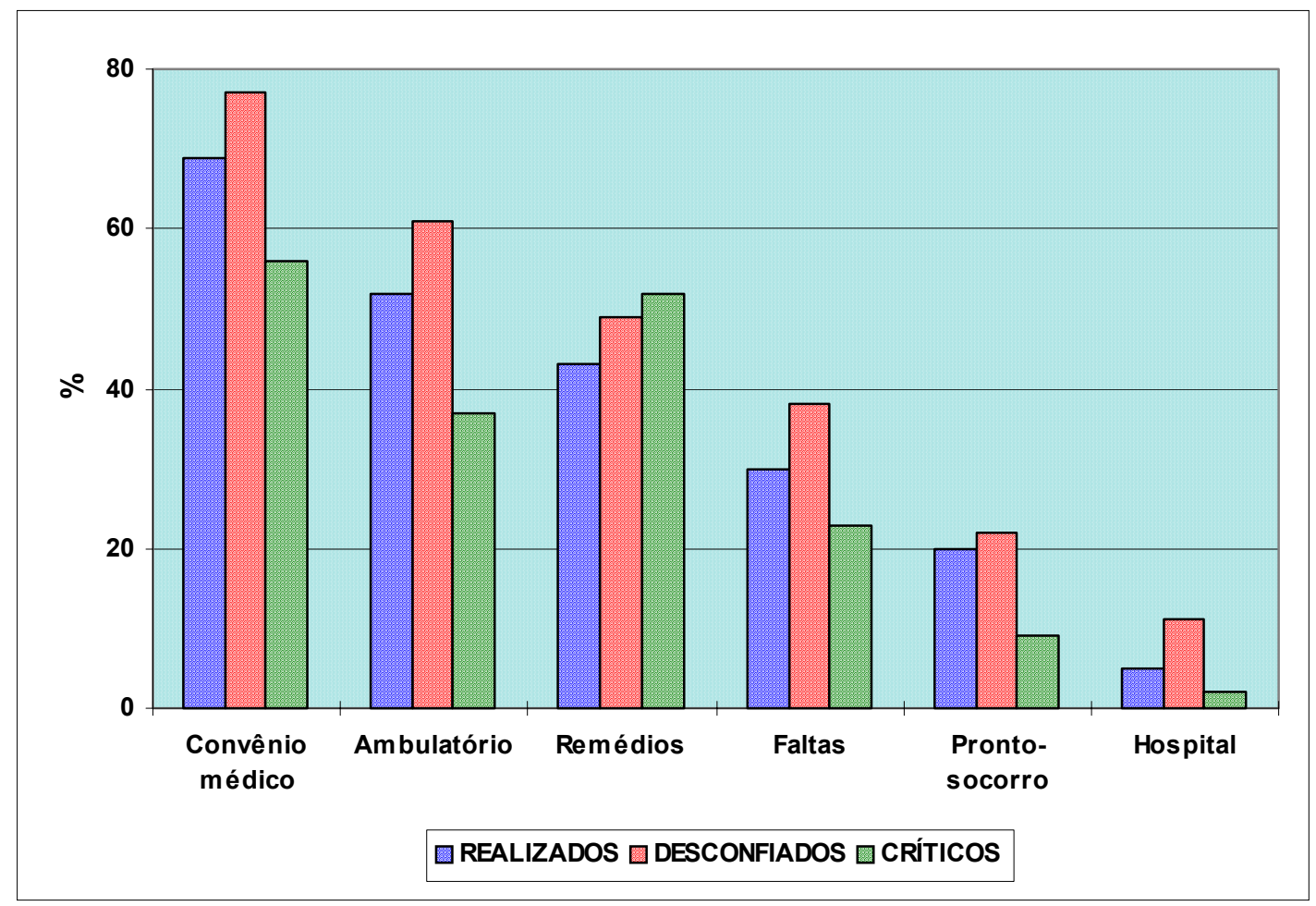

Gráfico 3.28 Ocorrências de doença nos últimos 12 meses.

Foram apenas comparados os conglomerados 1 e 2 , uma vez que, seria inviável comparar três conglomerados (uma casela com freqüência esperada menor que 5).

Observações: As únicas variáveis nominais que não podem ser consideradas independentes dos conglomerados são: nível hierárquico, utilização de convênio médico, utilização de serviço de saúde da unidade certificada.

Comparando-se apenas os dois primeiros conglomerados, ser internado em hospital mostrou comportamento significativamente diferente. 


\subsection{ISO 9000: PRESSÕES, MELHORIAS E OBSTÁCULOS}

"Com o estudo, a vida abriu para mim."

Operário, 55 anos

Para compreender os elementos de gestão das manufaturas com certificado ISO 9000, foram coletados dados sobre pressões externas:

- Melhorias de QVT necessárias à certificação ISO 9000.

- Obstáculos de QVT para a certificação ISO 9000.

- Outros programas de qualidade.

- Expectativas desejadas e atingidas de programas de QVT.

- Relação geral de melhorias e obstáculos. 


\subsubsection{Pressões externas}

Essa questão teve como objetivo identificar pressões externas à empresa que modificaram seus processos internos nos últimos 12 meses. Com base na revisão da literatura apresentada no Capítulo 2, item 2.3, foram levantados os seguintes fatores:

a. fiscalização;

b. sindicatos;

c. instituições certificadoras;

d. cliente;

e. matriz / corporação;

f. concorrentes.

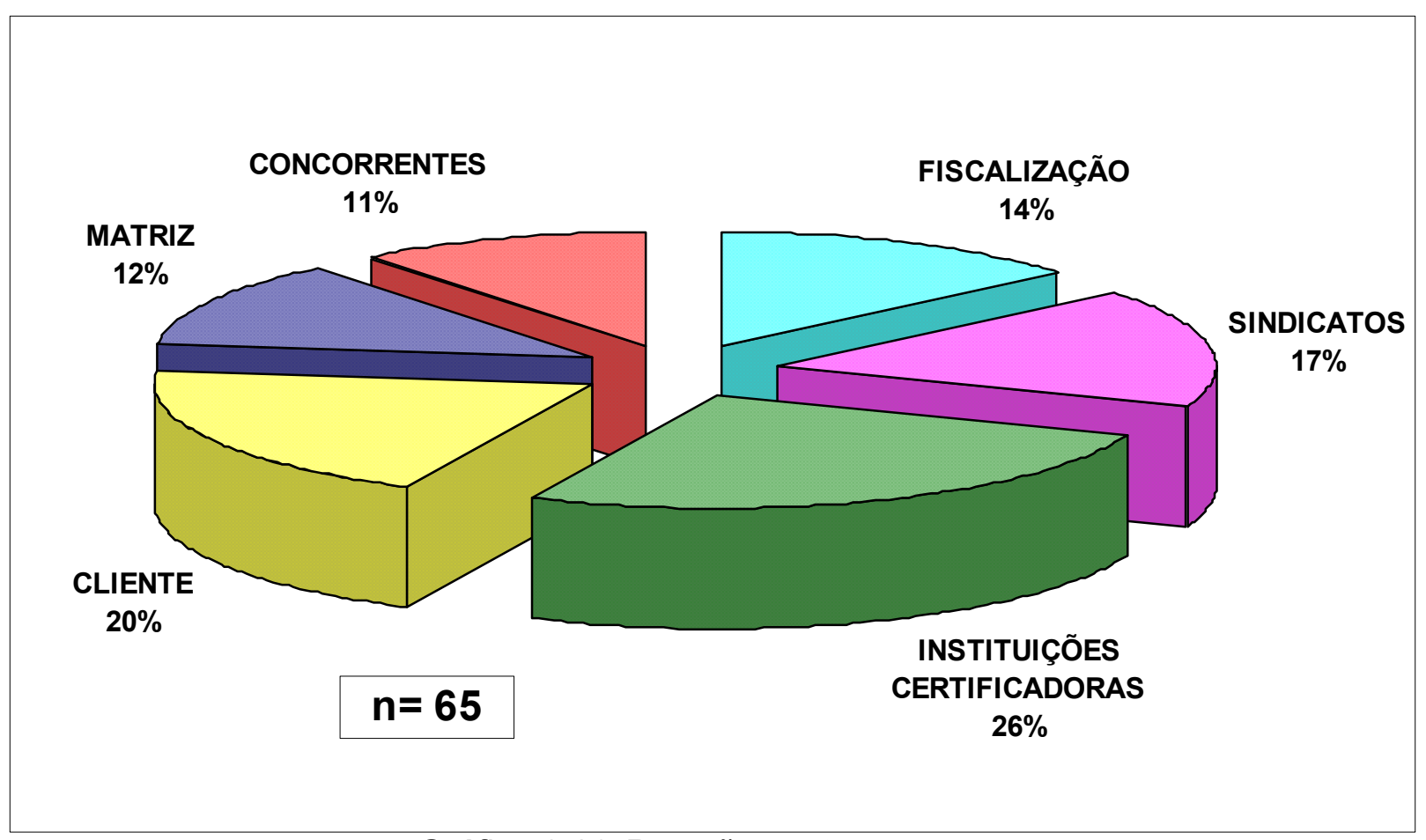

Gráfico 3.29 Pressões externas. 
O Gráfico 3.29 apresenta as porcentagens desses fatores, obtidas de respostas da gerência de recursos humanos. As porcentagens não são muito distantes em termos de comparações do total das respostas. Houve tendência em dizer sim ou não em algumas respostas; algumas vezes, a resposta foi confirmada por comentários verbais do pesquisado (especialmente as respostas não).

A maior pressão externa indicada foi das instituições certificadoras, seguindo-se de pressões de clientes e sindicatos.

A menor pressão percebida é a de concorrentes e da matriz ou sistema corporativo da empresa. Sobre a pressão de "concorrentes", parece indicar ser competitivo sem importar como. Isto confirma em parte o conceito de competitividade com problemas éticos estudado por Cerquinho (1994), Khel (1994) e Tsukamoto (1996), citados no Capítulo 1, item 1.3.

A baixa porcentagem de resposta de pressao da matriz/corporação está mais associada às unidades que têm matriz, e a grande maioria é uma unidade empresarial única.

As pressões, com porcentagens moderadas, de fiscalização e sindicatos estão muito associadas ao grau de risco ocupacional. As manufaturas do setor químico e produtos químicos são as mais expostas a pressões. Durante o processo de negociação e aplicação do questionário, uma delas recusou a pesquisa por estar em fase de negociação com sindicatos.

Ainda quanto à sindicalização, a maioria dos empregados e da gerência de recursos humanos não é sindicalizada. Proporcionalmente, o maior número de 
sindicalizados está na produção, mas não atinge metade do segmento (ver Tabela 3.13). Uma das empresas não permitiu a pesquisa com os empregados em função da proximidade das negociações de classe; em outra, indagaram se a pesquisadora não estava a serviço de algum sindicato de classe operária.

Tabela 3.13 Sindicalizados.

\begin{tabular}{|c|c|c|c|c|c|c|}
\hline & \multicolumn{4}{|c|}{ Funcionários (hierarquia) } & \multirow[t]{2}{*}{$\mathrm{RH}$} & \multirow{2}{*}{\begin{tabular}{|c|} 
Total de \\
funcionários \\
\end{tabular}} \\
\hline & 1 & 2 & 3 & 4 & & \\
\hline $\mathrm{N}$ & 110 & 22 & 8 & 9 & 8 & 149 \\
\hline$\%$ & 41.83 & 32.84 & 24.24 & 37.50 & 36.36 & 38.50 \\
\hline Total $(N)$ & 263 & 67 & 33 & 24 & 22 & 387 \\
\hline
\end{tabular}

Esses dados são comparáveis com os obtidos de empresas do setor químico e produção química aparece com gestão do tipo reativa.

Seria interessante incluir pressões internas, pois entre o alto índice de recusas à pesquisa, os motivos mais verbalizados durante a negociação foram: acúmulo de trabalho, preocupação com a imagem da empresa, no sentido de revelar falta de cuidado com a QVT - Qualidade de Vida no Trabalho - e, especialmente, muita pressão da diretoria e dos empregados sobre a gerência de recursos humanos.

Cruzando pressão externa das instituições certificadoras, conforme a Tabela 3.14, observa-se maior pressão da DWN e menor da ABS/QE. 
Tabela 3.14 Pressões das instituições certificadoras.

\begin{tabular}{|c|c|c|c|c|c|c|c|c|c|c|c|c|}
\hline PRESSÃO & \multicolumn{2}{|c|}{$\begin{array}{l}\text { FISCALI- } \\
\text { ZAÇÃO }\end{array}$} & \multicolumn{2}{|c|}{$\begin{array}{l}\text { SINDI- } \\
\text { CATOS }\end{array}$} & \multicolumn{2}{|c|}{$\begin{array}{c}\text { INSTIT. } \\
\text { CERTIFI- } \\
\text { CADORAS }\end{array}$} & \multicolumn{2}{|c|}{ CLIENTE } & \multicolumn{2}{|c|}{ MATRIZ } & \multicolumn{2}{|c|}{$\begin{array}{l}\text { CONCOR- } \\
\text { RENTES }\end{array}$} \\
\hline $\begin{array}{c}\text { INSTITUIÇÃO } \\
\text { CERTIFICADORA }\end{array}$ & $\mathrm{n}$ & $\%$ & $\mathrm{n}$ & $\%$ & $\mathrm{n}$ & $\%$ & $\mathrm{n}$ & $\%$ & $\mathrm{n}$ & $\%$ & $\mathrm{n}$ & $\%$ \\
\hline $\mathrm{ABS} / \mathrm{QE}$ & 5 & 50,0 & 5 & 50,0 & 6 & 60,0 & 4 & 40,0 & 2 & 22,2 & 3 & 30,0 \\
\hline $\mathrm{BSI}$ & 0 & 0,0 & 0 & 0,0 & 1 & 100,0 & 1 & 100,0 & 1 & 100,0 & 0 & 0,0 \\
\hline BVQI & 1 & 20,0 & 2 & 40,0 & 3 & 60,0 & 3 & 60,0 & 1 & 20,0 & 0 & 0,0 \\
\hline DWV & 2 & 66,7 & 2 & 66,7 & 2 & 66,7 & 2 & 66,7 & 1 & 50,0 & 2 & 100,0 \\
\hline INMETRO & 0 & 0,0 & 1 & 50,0 & 2 & 100,0 & 1 & 50,0 & 1 & 50,0 & 1 & 50,0 \\
\hline RWTUV & 1 & 100,0 & 0 & 0,0 & 1 & 100,0 & 0 & 0,0 & 1 & 100,0 & 0 & 0,0 \\
\hline $\begin{array}{l}\text { VANZOLINI/ ABS/ QE } \\
\qquad(n=1)\end{array}$ & 0 & 0,0 & 0 & 0,0 & 1 & 100,0 & 1 & 100,0 & 1 & 100,0 & 1 & 100,0 \\
\hline${ }^{\text {VANZOLINI/ DQS }}$ & 0 & 0,0 & 0 & 0,0 & 0 & 0,0 & 0 & 0,0 & 0 & 0,0 & 0 & 0,0 \\
\hline UCIEE & 0 & 0,0 & 1 & 100,0 & 1 & 100,0 & 1 & 100,0 & 0 & 0,0 & 0 & 0,0 \\
\hline
\end{tabular}

Para esta análise exploratória, não foi considerado o número total de respostas que é bastante diferente em dimensões: a ABS/QE certificou 10, dentre as pesquisadas, e a DWV certificou apenas três.

Outra comparação para rastrear pressões externas foi feita com cruzamento de pressões externas com ramo de atividade (ver Tabela 3.15). A maior pressão foi verificada nas instituições certificadoras sobre o segmento de computação e químico. Computação também sofre importante pressão externa para QVT por parte dos clientes. As empresas desse segmento apresentam estrutura organizacional e tecnológica diferenciada, com pessoal de perfil semelhante ao do ramo de aparelhos eletro-eletrônicos.

Tabela 3.15 Pressões nos ramos de atividade 


\begin{tabular}{|c|c|c|c|c|c|c|c|c|c|c|c|c|}
\hline \multirow{2}{*}{$\begin{array}{c}\text { PRESSÃO } \\
\text { RAMO }\end{array}$} & \multicolumn{2}{|c|}{$\begin{array}{l}\text { FISCALI- } \\
\text { ZAÇÃO }\end{array}$} & \multicolumn{2}{|c|}{$\begin{array}{l}\text { SINDI- } \\
\text { CATOS }\end{array}$} & \multicolumn{2}{|c|}{$\begin{array}{l}\text { INSTIT. } \\
\text { CERTIFI- } \\
\text { CADORAS }\end{array}$} & \multicolumn{2}{|c|}{ CLIENTE } & \multicolumn{2}{|c|}{ MATRIZ } & \multicolumn{2}{|c|}{$\begin{array}{l}\text { CONCOR- } \\
\text { RENTES }\end{array}$} \\
\hline & $n$ & $\%$ & $n$ & $\%$ & $n$ & $\%$ & $n$ & $\%$ & $n$ & $\%$ & $n$ & $\%$ \\
\hline $\begin{array}{l}\text { ELETRO- } \\
\text { ELETRÔNICOS } \quad \\
\end{array}$ & 2 & 40,0 & 4 & 80,0 & 4 & 80,0 & 4 & 80,0 & 2 & 40,0 & 1 & 20,0 \\
\hline $\begin{array}{l}\text { AUTOPEÇAS/ } \\
\text { TRANSPORTE }\end{array}$ & 1 & 33,3 & 1 & 33,3 & 1 & 33,3 & 2 & 66,7 & 0 & 0,0 & 1 & 33,3 \\
\hline METAL PRIMÁRIO $_{(n=2)}$ & 1 & 50,0 & 1 & 50,0 & 2 & 50,0 & 0 & 0,0 & 1 & 50,0 & 0 & 0,0 \\
\hline MEDIÇÃO & 0 & 0,0 & 0 & 0,0 & 1 & 50,0 & 1 & 50,0 & 1 & 50,0 & 2 & 100,0 \\
\hline COMPUTAÇÃO & 2 & 50,0 & 2 & 50,0 & 3 & 75,0 & 3 & 75,0 & 2 & 50,0 & 1 & 33,3 \\
\hline $\begin{array}{l}\text { METAIS EXCETO } \\
\text { TRANSPORTE } \quad(n=2)\end{array}$ & 0 & 0,0 & 0 & 0,0 & 1 & 50,0 & 0 & 0,0 & 0 & 0,0 & 0 & 0,0 \\
\hline $\begin{array}{l}\text { PRODUTOS DE } \\
\text { TECELAGEM }\end{array}$ & 0 & 0,0 & 0 & 0,0 & 0 & 0,0 & 0 & 0,0 & 0 & 0,0 & 0 & 0,0 \\
\hline QUÍMICOS & 3 & 42,9 & 3 & 42,9 & 5 & 71,4 & 3 & 42,9 & 3 & 33,3 & 2 & 28,6 \\
\hline
\end{tabular}

3.5.2 Melhorias de QVT associadas à certificação ISO 9000 
As palavras-chaves propostas foram:

- clareza de procedimentos;

- organização geral da empresa;

- valorização monetária dos empregados;

- contato mais próximo com o cliente;

- melhoria do sistema de alimentação;

- realização de ginástica laboral;

- desafios de metas para serem superados;

- programas de controle de doenças e acidentes;

- mais autonomia dos empregados nas decisões;

- novos benefícios para empregados e familiares;

- novas atividades culturais e esportivas;

- educação para o trabalho.

A palavra-chave para a implantação da ISO 9000 foi clareza de procedimentos, seguida de metas e educação, conforme se pode verificar no Gráfico 3.30. Essas escolhas são compatíveis com os procedimentos específicos do processo de certificação. A palavra-chave valorização está no mesmo nível de

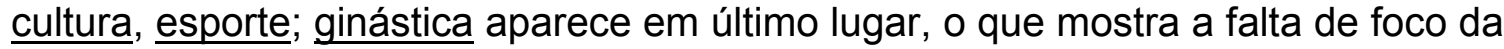
gestão ISO na valorização de pessoas.

Gráfico 3.30 Melhorias associadas à ISO 9000. 


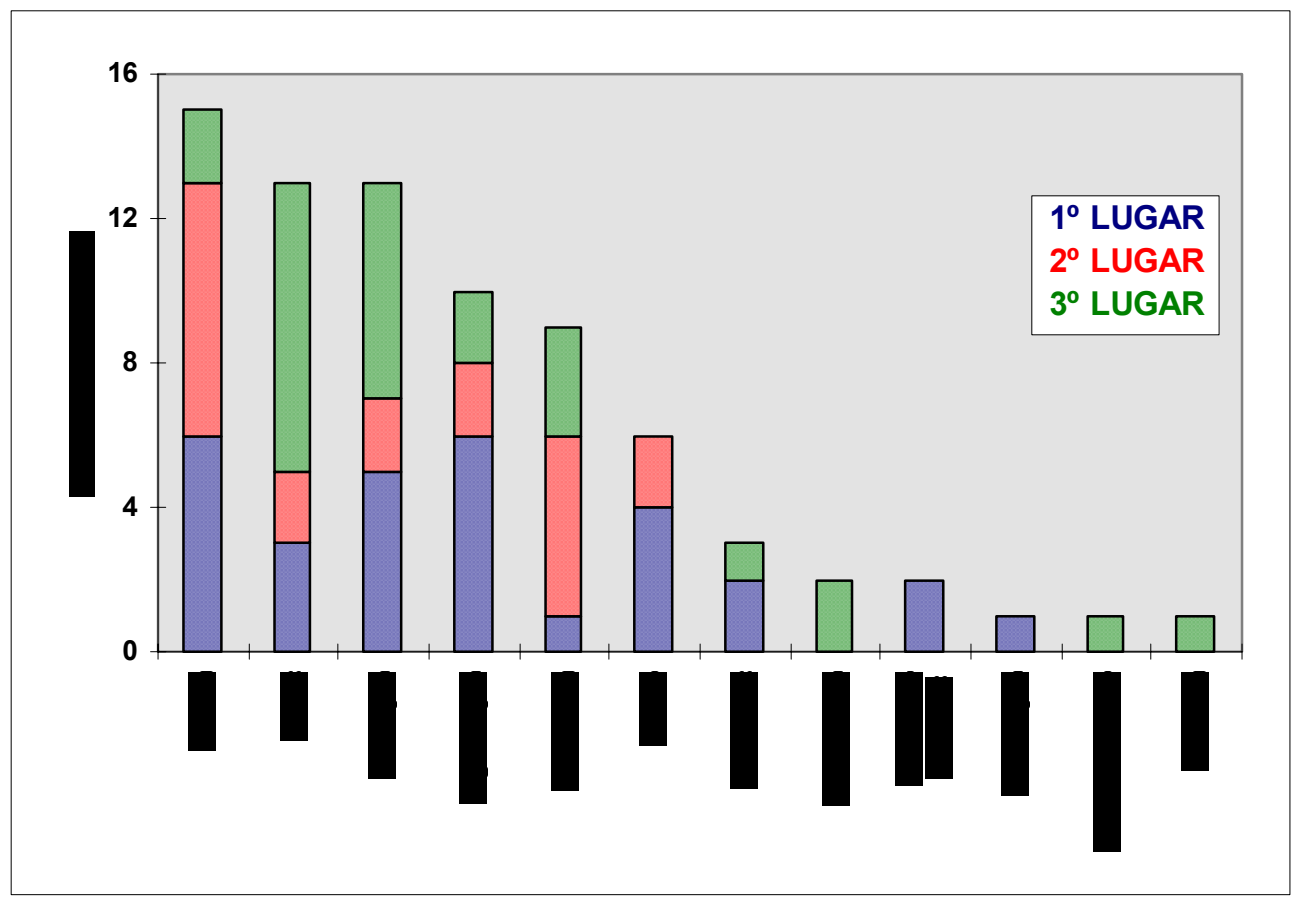

3.5.3 Obstáculos de QVT associados à certificação ISO 9000

As palavras-chaves quanto aos obstáculos de QVT associados à certificação ISO 9000 foram:

- processos de produção/tecnologia;

- existência de tarefas perigosas;

- pressão dos clientes;

- falta de qualificação profissional;

- condições socioeconômicas dos empregados;

- preparo da documentação;

- ausência por licenças médicas; 
- relacionamento entre os empregados;

- problemas familiares dos empregados;

- ausência de alimentação e repouso adequados;

- falta de motivação e interesse;

- cobrança excessiva de resultados.

Entre os aspectos que dificultam a implantação da ISO 9000, a palavrachave que obteve maior porcentagem foi motivação. Esta escolha é incoerente se se observa a posição de valorização do item anterior. As demais escolhas relacionam-se a questões de produção e tecnologia, associadas às dificuldades de modernização no ambiente de manufatura. Aspectos sociais e familiares não foram escolhidos e clientes aparecem em penúltimo lugar. Portanto, clientes só poucas vezes são vistos como obstáculos para a implantação da ISO 9000 .

A documentação, uma das grandes dificuldades do processo, aparece, no entanto, em terceiro lugar relativamente à porcentagem alcançada.

Outro aspecto a destacar é o relacionamento que não apareceu nem uma vez entre o obstáculo mais importante, o que pode indicar que, em princípio, existe receptividade ao programa.

Gráfico 3.31 Obstáculos associados à QVT. 


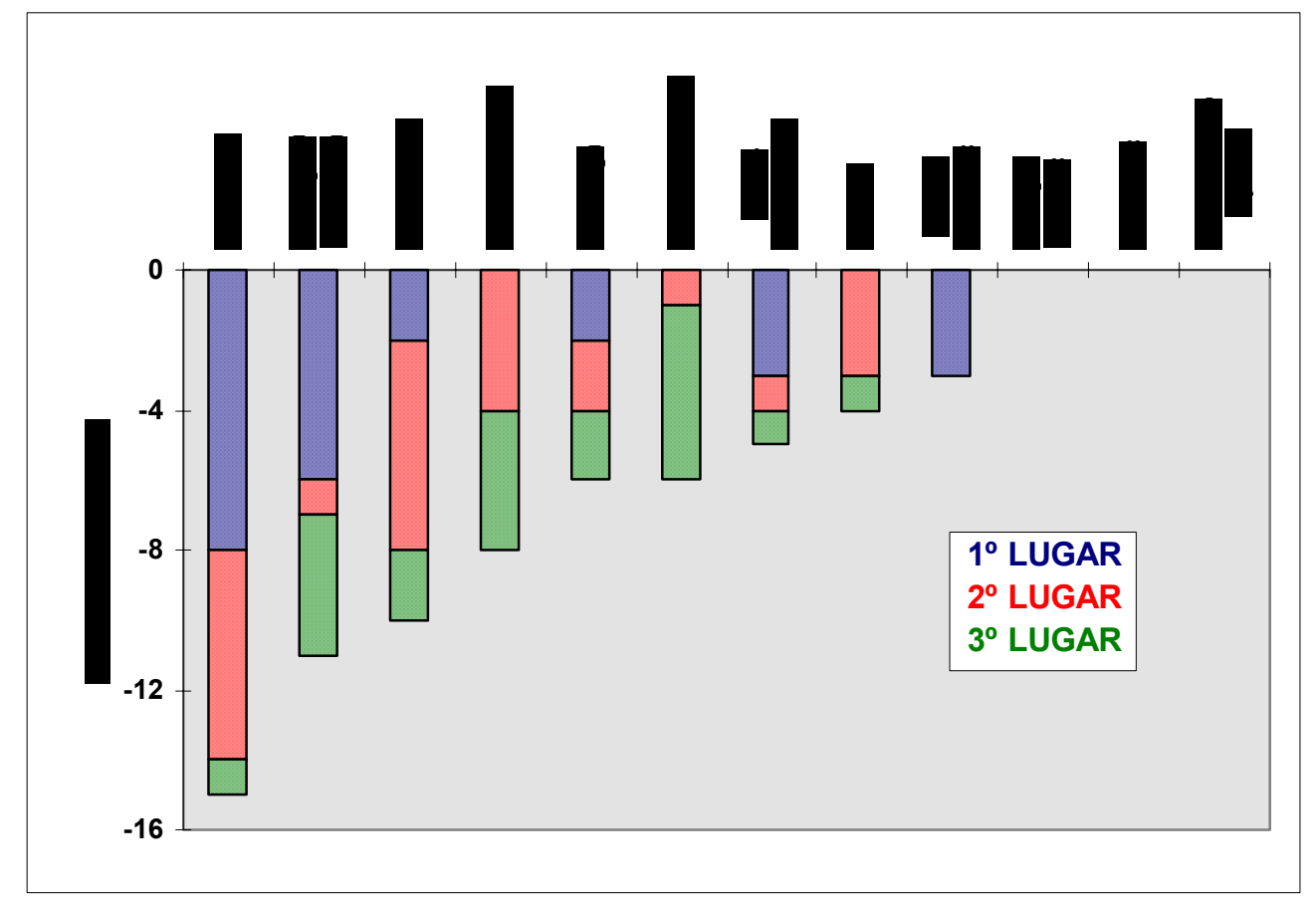

3.5.4. Outros programas de qualidade

Esta pergunta levantou a incidência de outros programas nestas unidades. A maioria delas tinha alguma outra ação de qualidade. Qualidade Total foi a mais indicada, seguida de CEP, dois programas familiares na cultura empresarial. Comitês de qualidade apareceram em apenas 34,5\% das respostas (ver Tabela 3.18). No entanto, este é um dos requisitos da ISO 9000.

Tabela 3.16 Programas de qualidade. 


\begin{tabular}{|c|c|c|}
\hline $\begin{array}{c}\text { AÇÕES DE QUALIDADE } \\
\text { TOTAL }\end{array}$ & $\begin{array}{c}\text { N }^{\circ} \\
\text { CITAÇÕES }\end{array}$ & $\begin{array}{c}\% \\
(n=26)\end{array}$ \\
\hline Juran & 1 & 3,8 \\
\hline PNQ & 3 & 11,5 \\
\hline Just in time & 5 & 19,2 \\
\hline TQC & 2 & 7,7 \\
\hline Qualidade total & 10 & 38,5 \\
\hline Crosby & 5 & 19,2 \\
\hline Kanban & 4 & 15,4 \\
\hline Kaizen & 3 & 11,5 \\
\hline 5 S & 7 & 26,9 \\
\hline CEP & 10 & 38,5 \\
\hline Comitês & 9 & 34,6 \\
\hline Outros & 6 & 23,1 \\
\hline
\end{tabular}

3.5.5 Ações e programas desejados e atingidos

Para entender os objetivos a médio prazo dos programas e ações mais freqüentes nas empresas, foram coletados os dados das Tabelas 3.16 e 3.17 , sobre a abrangência dos programas de empregados que deveriam ser atingidos.

O programa com melhor nível de realização foi refeitório. Já o programa transporte atingiu a meta somente de $70 \%$ dos empregados. 
No programa de previdência privada, as maiores diferenças encontram-se nos extremos, ou seja duas empresas tinham por objetivo atingir até $10 \%$ dos empregados.

A rotatividade aparece com alta variação de expectativas entre desejado e atingido. Já a redução do absenteísmo surge com baixa expectativa de controle, o que em décadas passadas era tido como um dos problemas sérios da administração de recursos humanos.

Os programas de saúde e segurança apresentaram ótimos índices de realização, o que confirma a tendência das empresas em ações desta natureza. É importante considerar que muitas dessas ações são obrigatórias por lei.

A cesta básica - um benefício bastante controvertido na prática das empresas - apresenta maior diferença entre o desejado e o atingido.

Gestão participativa deve ser um grande desafio, pois aparece com o maior índice de diferença entre o desejado e o atingido. É sinal do esforço necessário à modernização das empresas.

Tabela 3.17 Ações permanentes.

\begin{tabular}{|c|c|c|c|c|c|c|c|}
\hline AÇÕES & O A 10\% & 11 A $30 \%$ & 31 A $50 \%$ & 51 A $70 \%$ & 71 A $90 \%$ & $\begin{array}{r}91 \mathrm{~A} \\
100 \%\end{array}$ & $\begin{array}{c}\text { EM } \\
\text { BRANCO }\end{array}$ \\
\hline
\end{tabular}




\begin{tabular}{|c|c|c|c|c|c|c|c|c|c|c|c|c|c|c|}
\hline \multirow[t]{2}{*}{ PERMANENTES } & \multirow[b]{2}{*}{ DES } & \multirow[b]{2}{*}{ AT. } & \multirow[b]{2}{*}{ DES } & \multirow[b]{2}{*}{ AT. } & \multirow[b]{2}{*}{ DES } & \multirow[b]{2}{*}{ AT. } & \multirow[b]{2}{*}{ DES } & \multirow[b]{2}{*}{ AT. } & \multirow[b]{2}{*}{ DES } & \multirow[b]{2}{*}{ AT. } & \multirow[b]{2}{*}{ DES } & \multirow[b]{2}{*}{ AT. } & \multirow[b]{2}{*}{ DES } & \multirow[b]{2}{*}{ AT. } \\
\hline & & & & & & & & & & & & & & \\
\hline Refeições & 0,0 & 3,8 & 0,0 & 3,8 & 3,9 & 0,0 & 0,0 & 3,8 & 3,9 & $\begin{array}{c}15 \\
4\end{array}$ & $\begin{array}{c}69, \\
2\end{array}$ & $\begin{array}{c}65 \\
5\end{array}$ & $\begin{array}{c}23, \\
0\end{array}$ & 7,7 \\
\hline Transporte & 7,7 & $\begin{array}{c}15 \\
4\end{array}$ & 7,7 & $\begin{array}{c}11 \\
5\end{array}$ & 7,7 & $\begin{array}{c}11 \\
5\end{array}$ & 3,8 & $\begin{array}{c}11 \\
5\end{array}$ & 7,7 & $\begin{array}{c}15 \\
4\end{array}$ & $\begin{array}{c}42 \\
3\end{array}$ & $\begin{array}{c}15 \\
4\end{array}$ & $\begin{array}{c}23 \\
1\end{array}$ & $\begin{array}{c}19 \\
3\end{array}$ \\
\hline Previdência privada & 7,7 & $\begin{array}{c}38 \\
5\end{array}$ & 0,0 & 7,7 & 7,7 & 7,7 & 0,0 & 3,8 & 3,8 & 0,0 & $\begin{array}{c}37 \\
7\end{array}$ & $\begin{array}{c}15 \\
4\end{array}$ & $\begin{array}{c}23 \\
1\end{array}$ & $\begin{array}{c}26 \\
9\end{array}$ \\
\hline $\begin{array}{l}\text { Redução da } \\
\text { rotatividade }\end{array}$ & $\begin{array}{c}42 \\
3\end{array}$ & $\begin{array}{c}38 \\
5\end{array}$ & 0,0 & 3,8 & 3,9 & 3,8 & 0,0 & 3,8 & 0,0 & $\begin{array}{c}11 \\
5\end{array}$ & $\begin{array}{c}34 \\
6\end{array}$ & $\begin{array}{c}19, \\
2\end{array}$ & $\begin{array}{c}19 \\
2\end{array}$ & $\begin{array}{c}19, \\
2\end{array}$ \\
\hline $\begin{array}{l}\text { Redução do } \\
\text { absenteísmo }\end{array}$ & $\begin{array}{c}38 \\
5\end{array}$ & $\begin{array}{c}38 \\
5\end{array}$ & $\begin{array}{c}11 \\
5\end{array}$ & 7,7 & 0,0 & 0,0 & 0,0 & 3,8 & 0,0 & $\begin{array}{c}30 \\
8\end{array}$ & $\begin{array}{c}34 \\
6\end{array}$ & 7,7 & $\begin{array}{c}15 \\
4\end{array}$ & $\begin{array}{c}11 \\
5\end{array}$ \\
\hline Saúde e segurança & 0,0 & 0,0 & 0,0 & 3,8 & 0,0 & 0,0 & 7,7 & $\begin{array}{c}11 \\
5\end{array}$ & 3,8 & $\begin{array}{c}30 \\
8\end{array}$ & $\begin{array}{c}73, \\
1\end{array}$ & $\begin{array}{c}50 \\
0\end{array}$ & $\begin{array}{c}15 \\
4\end{array}$ & 3,8 \\
\hline Cesta básica & $\begin{array}{c}19 \\
2\end{array}$ & $\begin{array}{c}23 \\
1\end{array}$ & 0,0 & 3,8 & 0,0 & 3,8 & $\begin{array}{c}11 \\
5\end{array}$ & $\begin{array}{c}11 \\
5\end{array}$ & 7,7 & 7,7 & $\begin{array}{c}34 \\
7\end{array}$ & $\begin{array}{c}19 \\
2\end{array}$ & $\begin{array}{c}26 \\
9\end{array}$ & $\begin{array}{c}30 \\
8\end{array}$ \\
\hline Gestão participativa & 7,7 & $\begin{array}{c}11 \\
5\end{array}$ & 0,0 & $\begin{array}{c}15 \\
4\end{array}$ & 0,0 & $\begin{array}{c}11 \\
5\end{array}$ & 7,7 & $\begin{array}{c}15 \\
4\end{array}$ & 7,7 & $\begin{array}{c}11 \\
5\end{array}$ & $\begin{array}{c}61 \\
5\end{array}$ & $\begin{array}{c}15 \\
4\end{array}$ & $\begin{array}{c}15 \\
4\end{array}$ & $\begin{array}{c}19, \\
2\end{array}$ \\
\hline
\end{tabular}

Nos programas temporários, foram observados os maiores índices de atendimento entre $\mathrm{o}$ desejado $\mathrm{e}$ o atingido relativamente à melhoria de ferramentas de trabalho. O maior desafio parece ser melhorias no ambiente físico, uma vez que aparecem com expectativa de se alcançar o nível 91 a 100\% e no conglomerado só foram atingidos $30,8 \%$ desta meta.

Houve também muitas respostas em branco, isto é, não existem programas nos itens novos benefícios e campanha contra drogas. Este dado pode significar 
dificuldades em atender a demandas sociais que não estejam diretamente ligadas à empresa.

Tabela 3.18 Ações temporárias.

\begin{tabular}{|c|c|c|c|c|c|c|c|c|c|c|c|c|c|c|}
\hline \multirow{2}{*}{$\begin{array}{c}\text { AÇÕES } \\
\text { TEMPORÁRIAS }\end{array}$} & \multicolumn{2}{|c|}{0 a $10 \%$} & \multicolumn{2}{|c|}{11 a $30 \%$} & \multicolumn{2}{|c|}{31 a $50 \%$} & \multicolumn{2}{|c|}{51 a $70 \%$} & \multicolumn{2}{|c|}{71 a $90 \%$} & \multicolumn{2}{|c|}{91 a $100 \%$} & \multicolumn{2}{|c|}{$\begin{array}{c}\text { EM } \\
\text { BRANCO }\end{array}$} \\
\hline & DES & AT. & DES & AT. & DES & AT. & DES & AT. & DES & AT. & DES & AT. & DES & AT. \\
\hline $\begin{array}{l}\text { Melhorias no ambiente } \\
\text { físico }\end{array}$ & 3,8 & 3,8 & 3,8 & 7,7 & 3,8 & 15,4 & 3,8 & 19,2 & 7,8 & 7,7 & 57,8 & 30,8 & 19,2 & 15,4 \\
\hline $\begin{array}{l}\text { Melhoria nas } \\
\text { ferramentas }\end{array}$ & 3,8 & 3,8 & 0,0 & 7,7 & 11,6 & 19,2 & 3,8 & 11,5 & 15,4 & 15,4 & 46,2 & 26,9 & 19,2 & 15,4 \\
\hline Campanha sobre AIDS & 3,8 & 7,7 & 0,0 & 7,7 & 0,0 & 7,7 & 7,7 & 15,4 & 7,7 & 15,4 & 57,7 & 30,8 & 23,1 & 15,4 \\
\hline $\begin{array}{l}\text { Campanha sobre } \\
\text { drogas }\end{array}$ & 7,7 & 23,1 & 0,0 & 3,8 & 0,0 & 3,8 & 7,7 & 7,7 & 3,8 & 11,5 & 50,0 & 26,9 & 30,8 & 23,1 \\
\hline Campanha sobre fumo & 7,7 & 26,9 & 0,0 & 0,0 & 3,8 & 7,7 & 7,7 & 7,7 & 7,7 & 11,5 & 50,0 & 26,9 & 23,1 & 19,2 \\
\hline Controle de obesidade & 15,4 & 26,9 & 3,8 & 3,8 & 7,7 & 7,7 & 3,8 & 7,7 & 7,7 & 11,5 & 23,1 & 0,0 & 38,5 & 42,3 \\
\hline $\begin{array}{l}\text { Controle do } \\
\text { desperdício }\end{array}$ & 3,8 & 3,8 & 3,8 & 11,5 & 7,7 & 7,7 & 3,8 & 26,9 & 3,8 & 3,8 & 53,9 & 26,9 & 23,2 & 19,2 \\
\hline Novos benefícios & 3,8 & 15,4 & 15,4 & 7,7 & 0,0 & 0,0 & 3,8 & 19,2 & 0,0 & 3,8 & 38,5 & 11,5 & 38,5 & 42,3 \\
\hline
\end{tabular}

3.5.6 Melhorias percebidas para Qualidade de Vida no Trabalho 
Esses dados foram coletados em pergunta aberta. No questionário apresentado aos empregados havia a alternativa não sei nenhuma.

Foram listadas as respostas, em que pode ser observado grande número de demandas para cesta. Em seguida, aparece convênio médico. Uma das empresas havia suspendido o convênio por problemas financeiros. Creche e cursos técnicos confirmam as notas baixas dadas nas questões fechadas.

Tabela 3.19 Ações que faltam.

\begin{tabular}{|ll|}
\hline \multicolumn{2}{|c|}{ Empregados } \\
\hline Abono produtividade & Condições de trabalho \\
Amor & Criação de grêmio recreativo \\
Apoio à realização de cursos externos & Curso de $2^{\circ}$ grau \\
Aposentadoria particular & Convênio com faculdades \\
Área de lazer (7) & Convênio com psicólogo-terapeuta \\
Áreas esportivas & Convênio com papelaria \\
Assistencia social (5) & Cooperativa para fins de ajuda futura \\
Atendimento aos filhos/creches (7) & Falta tudo \\
Atendimento em ambulatório (8) & Férias, área de lazer \\
Atendimento médico & Financiamento para cursos externos (4) \\
Atuação CIPA (4) & Gerência se preocupa mais com a empresa \\
Atuação dos cipeiros & Convênio odontológico (2) \\
Aumento da abrangência de benefícios & Falta de transporte coletivo (2) \\
Auxiliar do chefe encarregado ou líder & Curso profissionalizante (2) \\
Auxílio-creche & Cursos técnicos (8) \\
Avaliação do trabalho & Esporte \\
Banheiro melhor & Cursos mais aprofundados para cada área \\
Biblioteca comunitária & Determinação do núcleo de trabalho \\
Café, pão com manteiga & Enfermaria (2) \\
Campo, quadras & Estacionamento (com seguro -2$)$ \\
Cargos (2) & Devolução dos vales transporte \\
Cesta básica (40) & Creche (8) \\
Clima para os funcionários & Melhora de almoço \\
Clube (4) & Estudos de sugestões \\
Colônia de férias & Excursões, colônia de férias \\
Comitê de participação dos funcionários & Entusiasmo, motivação, etc. \\
Comunicação & Grêmio \\
Confiança (5) & Estender o convênio a outros Estados \\
Crescimento profissional & Divulgação da empresa para os funcionários \\
\hline & \\
\hline
\end{tabular}

(continuação) 
Ginástica feminina

Salários (2)

Transporte (4)

Ação de recursos humanos

Assistência odontológica

Assistente social

Cesta básica

Comportamentais ex para células

Consciência

Conscientização da diretoria

Convênio médico

Definição de programa

Eliminação de cartão de ponto

Ginástica no local do trabalho

Ginástica laboral (2)

Contratação de especialista

Diminuição de hora-extra

Grêmio esportivo (2)

Educação no e para o trabalho

Eliminação do cartão de ponto

Ênfase nos recursos humanos

Vestiário

Humanização no trabalho

Previdência privada

Salários melhores um plano de carreira (20)

$1^{\circ}$ grau para os operários

Sistema de qualidade

Nova fábrica

Gerente ambiental

Informatização
Convênio médico (15)

Convênio com farmácias em outras regiões

Convênio com supermercado

Grêmio mais atuante

Incentivo

Lazer

Motivacionais, prêmios, etc.

Plano de assistência odontológica

Previdência privada

Programa de aposentadoria

Recursos financeiros

Redução de burocracia

Redução de jornada de trabalho Vontade

Diálogo aberto entre os cargos

Enfermeira e médico diariamente

Equipamentos qualificativos

Escola na empresa

Executação o planejamento

Facilitação o relacionamento

Festas

Fornecimento toalhas de banho

Ganhei um aparelho de som

Ganhei um multitost do pil

Grupos de negociação sobre salários

Informação

ISO 9002

Lavagem de uniformes

Layout

Limpeza e organização

(continuação)

\begin{tabular}{l}
\hline Incentivo ao alto desenvolvimento \\
Ar-condicionado na sala \\
Incentivo para a área de segurança \\
Revezamento do pessoal \\
Investimento qualidade (4) \\
Não sei (11) \\
Nenhuma (75) \\
Negociação de um novo plano de saúde \\
Palestras inclusão em comitês extra rotina \\
Operário ter acesso aos postos de \\
procedimento \\
Organização de processo \\
Reunião / trabalho em grupo \\
Pintura do chão da fábrica \\
Plano de carreira \\
Valorização dos funcionários \\
Plantão médico \\
Boa alimentação \\
Ventilação dos setores e limpeza \\
House keeping \\
Vestiário novo (2)
\end{tabular}

Máquinas modernas

Me deu emprego

Melhoria do ambiente, limpeza

Minimização ruídos

Mudança de direção

Mudança de fábrica (física)

Mudança no convênio médico (13)

Mudança da qualidade de trabalho

Plano participação nos resultados (4)

Programa Nuno Cobra (3)

Reavaliação das tarefas

Redução de ruído (2)

Reformas

Restaurante (35)

Segurança (14)

Trabalho

Treinamento (13)

Troca de assistência dentária

Vacina contra gripe

Visual da empresa (2) 
Ginástica laboral (2)

Contratação de especialista

Diminuição de hora-extra

Grêmio esportivo (2)

Educação no e para o trabalho

Eliminação do cartão de ponto

Ênfase nos recursos humanos

Vestiário

Humanização no trabalho

Previdência privada

Salários melhores um plano de carreira (20)

$1^{\circ}$ grau para os operários

Sistema de qualidade

Nova fábrica

Gerente ambiental

Informatização
Diálogo aberto entre os cargos

Enfermeira e médico diariamente

Equipamentos qualificativos

Escola na empresa

Executação o planejamento

Facilitação o relacionamento

Festas

Fornecimento toalhas de banho

Ganhei um aparelho de som

Ganhei um multitost do pil

Grupos de negociação sobre salários

Informação

ISO 9002

Lavagem de uniformes

Layout

Limpeza e organização

(continuação)

\begin{tabular}{l}
\hline Incentivo ao alto desenvolvimento \\
Ar-condicionado na sala \\
Incentivo para a área de segurança \\
Revezamento do pessoal \\
Investimento qualidade (4) \\
Organização \\
Visual da empresa (2) \\
Negociação de um novo plano de saúde \\
Palestras inclusão em comitês extra rotina \\
Operário ter acesso aos postos de \\
procedimento \\
Organização de processo \\
Reunião / trabalho em grupo \\
Pintura do chão da fábrica \\
Plano de carreira \\
Valorização dos funcionários \\
Plantão médico \\
Boa alimentação \\
Ventilação dos setores e limpeza \\
House keeping \\
Vestiário novo (2)
\end{tabular}

Incentivo ao alto desenvolvimento

Ar-condicionado na sala

Revezamento do pessoal

Investimento qualidade (4)

Organização

Visual da empresa (2)

egociação de um novo

Operário ter acesso aos postos de

ocedimento

Reunião / trabalho em grupo

Pintura do chão da fábrica

Valorização dos funcionários

antão médico

Ventilação dos setores e limpeza

House keeping

Vestiário novo (2)

\author{
Máquinas modernas \\ Me deu emprego \\ Melhoria do ambiente, limpeza \\ Minimização ruídos \\ Mudança de direção \\ Mudança de fábrica (física) \\ Mudança no convênio médico (13) \\ Mudança da qualidade de trabalho \\ Plano participação nos resultados (4) \\ Programa Nuno Cobra (3) \\ Reavaliação das tarefas \\ Redução de ruído (2) \\ Reformas \\ Restaurante (35) \\ Segurança (14) \\ Trabalho \\ Treinamento (13) \\ Troca de assistência dentária \\ Vacina contra gripe \\ Não se1 (11) / Nenhuma (75(
}


Tabela 3.20 Melhorias em QVT.

\begin{tabular}{|ll|}
\hline \multicolumn{2}{|c|}{ Gerência de Recursos Humanos } \\
\hline $\begin{array}{l}\text { Alimentação e saúde do empregado e } \\
\text { familiares }\end{array}$ & Multiplicação conceitos de qualidade \\
Atuação responsável e qualidade total & Condicionamento físico Nuno Cobra \\
Benefícios (3) & Plano de carreira \\
Certificação ISO 9002 & Participação nos resultados (3) \\
Controle médico da saúde ocupacional & Melhorias no ambiente físico/ferramentas \\
Gestão do desempenho autônomo & Saúde e segurança (3) \\
House keeping & TQM - Total Quality \\
Treinamento profissional & \\
\hline
\end{tabular}

As melhorias (ver Tabela 3.20) obtidas nas respostas das gerências de recursos humanos apresentam associações com atividades ligadas à certificação, qualidade e desenvolvimento profissional, além dos tradicionais focos em saúde e segurança.

Nas respostas dos empregados, pode ser constado grande número de nenhuma das alternativas (75) e não sei (11).

Entre as melhorias mais citadas - restaurante, salários e plano de carreira - há novidades, como as referentes às relações de trabalho, com acesso à sala de procedimentos, eliminação de cartão de ponto e plano de participação nos resultados. 


\subsection{ESTRUTURA ORGANIZACIONAL DE QVT}

O principal objetivo da investigação da estrutura organizacional de QVT foi reconhecer elementos de gestão que caracterizassem a forma de atendimento às demandas de qualidade de vida das manufaturas

As estruturas de gestão são um dos elos de ligação entre empresa e empregados que interferem nas ações da gerência de recursos humanos e, conseqüentemente, na satisfação dos empregados. O conceito de estrutura é amplo, variando de uma visão comportamental - "além da hierarquia" com ênfase na gestão participativa (Albuquerque, 1996 e Maximiano, 1995), até a visão que pode significar estrutura no sentido da divisão de atividades e autoridades (Vasconcellos e Hemsley, 1989), conjunto de unidades básicas de trabalho (Sbragia, 1982).

A referência conceitual utilizada para a seleção das variáveis foi o desenho organizacional da área. Considera-se estrutura um conjunto de funções e poderes formalizados, com ações gerenciais específicas, dotação financeira, medidas de resultado e posicionamento do contexto estratégico da empresa.

Com o intuito de identificar estágios de gestão, buscou-se um índice que discriminasse as empresas. 
3.6. 1 Índice das estruturas

O índice foi composto por variáveis cuja importância deve ser inversamente proporcional a sua presença em relação a todas as unidades certificadas. De acordo com respostas afirmativas ou negativas, foram obtidas as seguintes distribuições:

1. A empresa possui uma diretoria responsável pelos projetos de QVT?

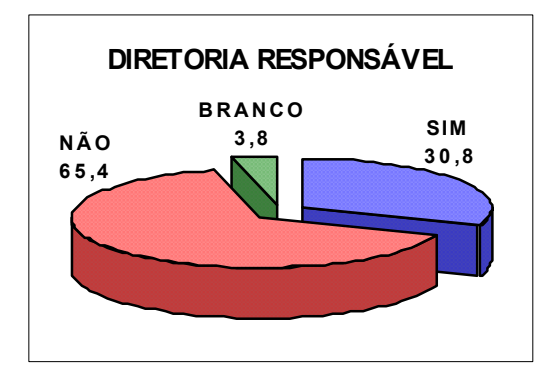

RESULTADO

Recursos Humanos: 3

Gestão da Qualidade: 1

Tecnologia e Qualidade: 1

Administrativa:

Técnica:
1

2

\section{COMENTÁRIOS}

A maioria das empresas não possui diretoria

própria, e quando há diretoria responsável está mais ligada à Recursos Humanos e Qualidade. 
2. Existe um poder decisório definido?

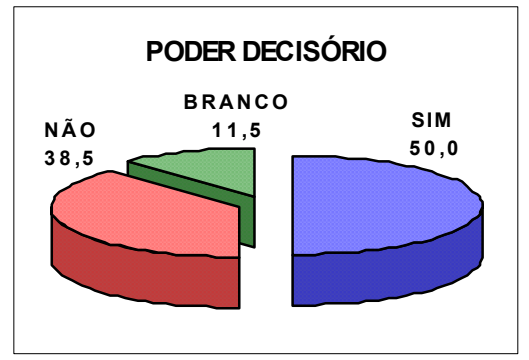

Direção: $\quad 9$

Gerência: 6
Existe poder decisório para QVT na maioria das empresas pesquisadas, com ênfase no nível de direção, sugerindo ações mais estratégicas do que gerenciais.

3. Existem áreas específicas envolvidas?

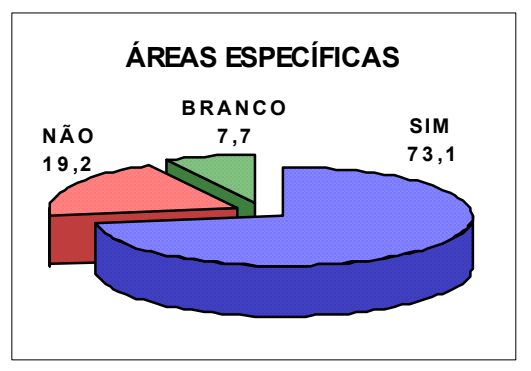

Recursos Humanos: 18

Saúde e Segurança: 14 Ambulatório Médico: 11 Beneficios: $\quad 12$ $5 s$ : 1
Existem áreas específicas mais concentradas em Recursos Humanos e Saúde. Na área de qualidade apareceu uma empresa que associou QVT ao programa 5s.

\section{Existem funcionários especialmente envolvidos com atividades de QVT?}

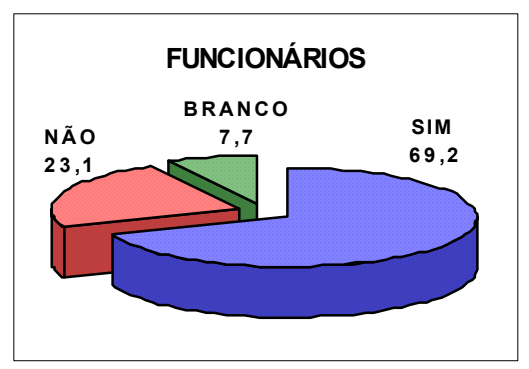

1 a 5 funcionários: 10

6 a 10 funcionários: 3 mais de 10:
A maioria das empresas têm funcionários envolvidos com atividades de QVT, em geral equipes de 1 a 5 funcionários. Algumas 
das empresas pequenas relataram ter equipes com mais de 10 funcionários, o que indica uma boa mobilização organizacional para estas ações e programas em QVT. 
5. Há métodos para levantar necessidades de QVT na sua empresa?

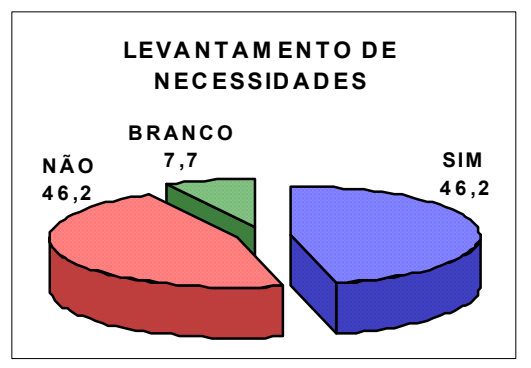

Número de acidentes: $\quad 11$

Demanda no ambulatório: 7

Há uma pequena maioria de empresas

Diagnóstico do clima: 7:via programa de $Q T$ procedimentos de levantamento de neces-

Determinação legal: $\quad 3$

Auditoria interna:
Outros: $1:$ satisfação cliente interno

sidades através de freqüência de acidentes

no trabalho, movimento no ambulatório, diagnóstico de clima e auditoria interna. Poucas declararam associação com determinação legal.

6. É possivel identificar o tempo de existência das atividadade de QVT?

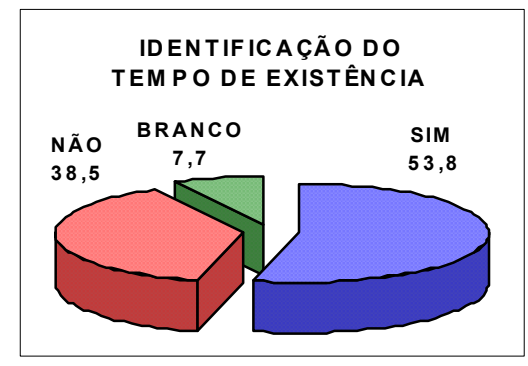

até 1 ano: 1

1 a 3 anos: $\quad 8$

3 a 5 anos: 1

mais de 5 anos: 4
A maioria das empresas identificou um tem-

po de 1 a 3 anos para existência dos programas de QVT. O que significa uma modesta posição consolidada para os mesmos. Houve um grupo de empresas que percebe a existência com mais de 5 anos, caracterizando mais solidez e visibilidade destas ações na empresa.

7. Existem propostas para novos programas nos próximos doze meses? 


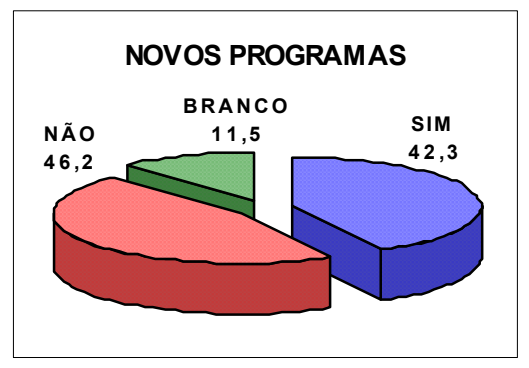

Definir metas, envolver áreas, levantar necessidades, medir resultados.

Melhoria contínua.

100\% assistência médica, 100\% segurança e medicina, satisfação dos usuários.

Reunião Coach, qualidade de vida. Pressão arterial, nivel de ruído. Ações comportamentais para aposentados, política única de QVT para o grupo.

Atuação responsável, melhorias, $5 \mathrm{~s}$, parte do projeto de Qualidade Total.

8. É possível avaliar a duração das atividades?
Na maioria não existem propostas de novos programas.

Nas empresas que responderam sim, a ên-

Fase é de procedimentos de implantação e

Já se começa a considerar os empregados Como foco de ação de QVT.

Uma das empresas associou novos prograMas ao 5s do Projeto de Qualidade Total.

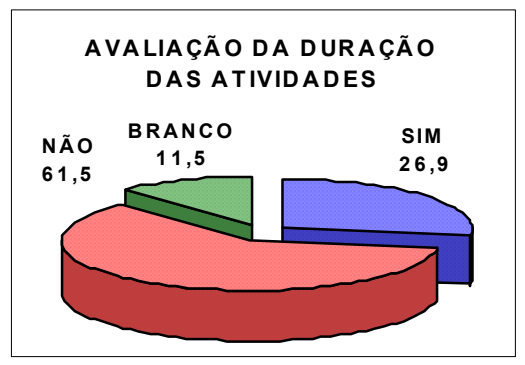

Qual a duração total dos serviços ou As atividades em sua maioria não têm projetos de QVT?

Horas: 1 (2 a 4 )

Dias: 1

Meses: 2

Anos: 3 (1 empresa: 3 anos)

Contínuo: 2 duração prevista. As que têm apontaram de 2 horas a 3 anos, além de duas indiçações para duração contínua. Percebe-se um esco-

po muito abrangente, caracterizando falta de um modelo mais homogêneo e referencial para a gestão da QVT.

9. Há dotação orçamentária? 


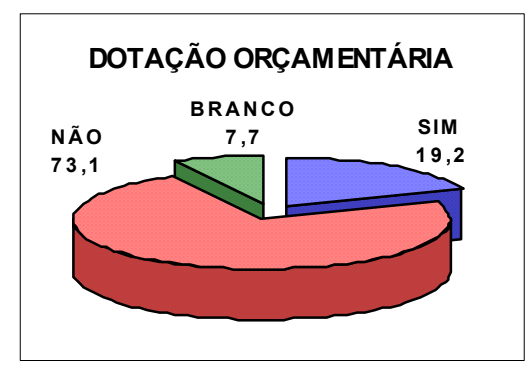

Anual: 3 ( uma empresa: $R \$ 36.000,00)$ Outros:2 (uma parte permanenteloutra tem-

porária, específica em saúde ocupacional
Na maioria das empresas não há dotação orçamentária. Nas que existe indicou-se anual e parte do programa de saúde ocupacional, o que demonstra frágil estrutura orçamentária para QVT. 
10. Há uma destinação orçamentária (vinculada) específica?

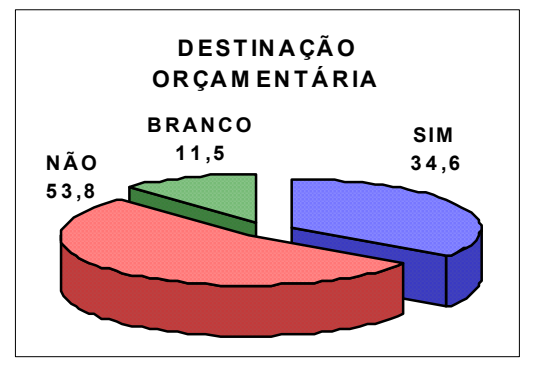

Departamento: 3

Projeto: $\quad 4$ (rateio)

Outros: $\quad 4$ (geral, por item de QVT)
Na maioria das empresas a destinação da verba não é específica. Nas empresas que possuem dotação específicas os critérios são variados: depto., projeto e genérico.

11. Existe uma porcentagem calculada de investimento com relação ao faturamento anual?

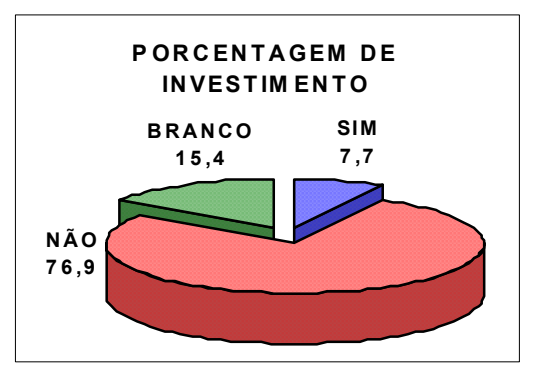

Porcentagem 0,01 a 0,90\%: 2 1,00 a 1,50\%: 1 (folha mensal)
Apenas uma minoria (20\%) das empresas calcula o investimento com o faturamento anual.As porcentagens são de 0,01 a $0,90 \%$ e também de 1,00 a $1,5 \%$ da folha de pagamento mensal.

12. Existem atividades formais denominadas Qualidade de Vida no Trabalho?

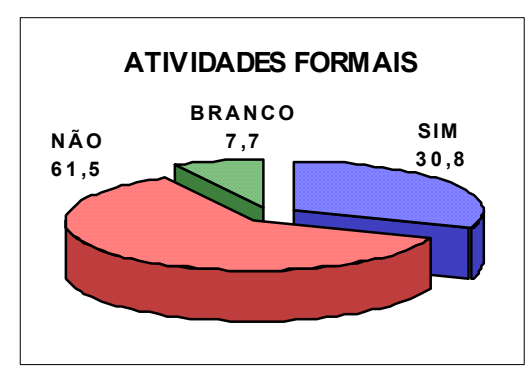

Campanhas

Palestras

Novos beneficios
5

5

1
Apenas 1/3 das empresas possuem atividades com nome de QVT, dentre estas as atividades mais citadas são campanhas e 
Melhorias no posto de trabalho Mudanças administrativas pales-

tras. Melhorias no posto de trabalho e umdanças administrativas aparecem, embora em menor incidência. 
13. Existe controle de resultados?

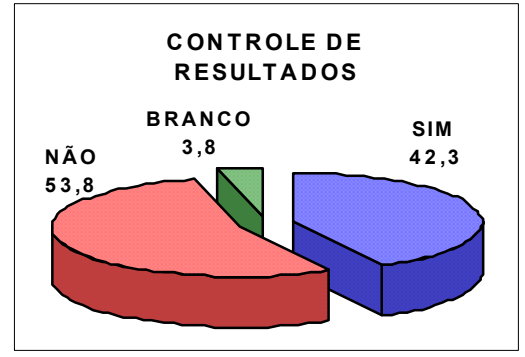

Questionários: 5 (absenteísmo, doenças)

Controle numérico 5 (ações de saúde)

Comitês de avaliação 4

Diálogo 1

Reuniões mistas 1
A maioria das empresas não controla os resultados associados à QVT. Dentre as que o fazem os controles referem-se mais à saúde e doença com dados obtidos através de questionários e controles numéricos. Os comitês de avaliação aparecem em quase metade das empresas como instrumento de avaliação. Em geral as empresas assinalaram múltiplas ferramentas de controle.

14. Os programas e ações de QVT tem uma importância na certificação ISO 9000?

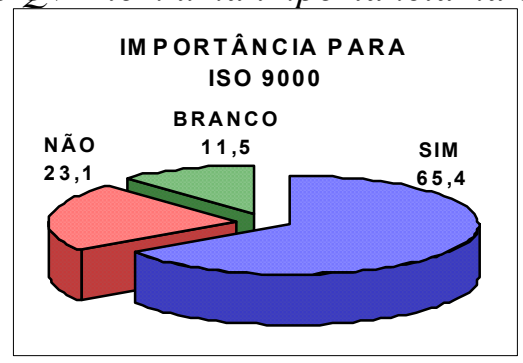

- Qualidade pessoal é base da qualidade profissional

- Negócio

- Satisfação em relação ao funcionário e ao mercado

- Treinamento

- Integração entre empresa e colaborador

- Algumas exigências das normas

- Já faziam programa antes da certificação

- Exigência do cliente externo

- Desempenho profissional

- Reflete na motivação do pessoal

- Se a pessoa não está satisfeita nenhuma ferramenta de trabalho vai em frente.
Esta questão demonstra a importância que se atribui à QVT associada à ISO 9000. A maioria absoluta das empresas considera importante. Os motivos focaram distribuídos em questões de qualidade, aten-

dimento à necessidades pessoais e até ao negócio da empresa, inclusive com relato de

pressão de cliente externo. 
- Motivação

- Atendimento do empregado é indispensável

- É um subconjunto de qualidade total

- Produtividade e qualidade

15. Os programas e ações de QVT tem valor para a política de negócios da empresa?

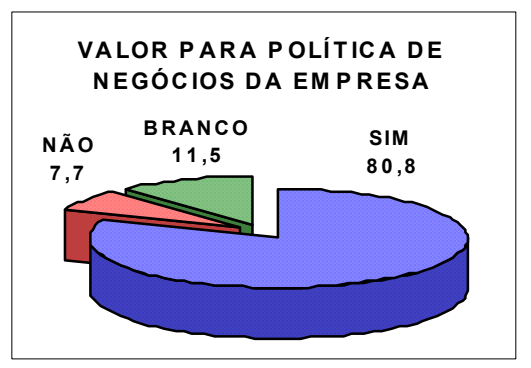

- Fortalecimento da cultura da empresa

- Continuidade

- Marketing da empresa

- O colaborador

- Alcançar resultados requer estar gostando do trabalho

- Adequação

- Condições para o desenvolvimento do negócio

- Imagem, imagem social

- Qualidade Tota.

- Trás retorno de resultado.

- Motivação, estado de espírito

- GM levanta estes aspectos da fábrica

- Participação nos lucros
As respostas positivas foram as maiores, Com relação a todas as outras questões. Os motivos apontados associam-se a empresa como um todo, à imagem da empresa,

Ao envolvimento dos empregados e auditoria de clientes externos.

Comparando as respostas sim e não pode-se observar que: 
- a maioria das empresas não possui diretoria responsável, mas grande parte considera a gestão da qualidade de vida importante para certificação ISO 9000, e para a política de negócios da empresa;

- existem áreas e funcionários específicos para as atividades de qualidade de vida, na maioria das empresas (em torno de $70 \%$ ), o que sugere presença de esforço, mas não estruturado;

- não existem medidas efetivas de retorno de investimento. Só a minoria das empresas tem previsão da duração das atividades e dotação orçamentária;

- há boa incidência de propostas de novos programas se associados ao caráter não estratégicos dessas atividades.

Os resultados demostram que:

- Aspectos gerenciais: Diretoria: a maioria das empresas pesquisadas declarou que não tem uma diretoria responsável pela gestão de ações e programas de qualidade de vida no trabalho. O que implica na difusão das decisões e provavelmente ausência de alinhamento gerencial com outras metas da organização. No entanto, observa-se que Poder Decisõrio, Áreas Específicas e Funcionários encontra-se mais presente, o que indica presença de decisões a nível mais operacional e tático do que estratégico.

- Procedimentos operacionais: O levantamento de necessidades ocorre em boa parte das empresas, o que pode indicar foco nas ações, embora muitos procedimentos associados a levantamento de necessidades estejam mais ligadas às exigências legais de saúde e segurança do que à procura de diagnóstico específico. Avaliação de resultados aparece em um terço das empresas, o que sinaliza juntamente com Controle de Resultados fraca ligação com compromISO para melhorias ou mudanças. 
- Estágio de Maturidade da Gestão: Para a maioria das empresas pesquisadas, o tempo de existência dos programas está acima de um ano, o que demonstra moderada consolidação; entretanto, a tendência de expansão de novos programas não teve número significativo de respostas positivas. Pode-se dizer que o estágio de gestão não é inicial e que existe uma intenção de expansão a partir da alta percentagem de respostas positivas para a "Importância da Qualidade de Vida na Política da Empresa" e "Gestão da ISO 9000".

- Investimento Financeiro: As respostas apontam para uma certa formalização orçamentária não atrelada a resultados globais, especialmente no que se refere indicação de porcentagem de investimento.

Estes itens da gestão mostram que existem uma distância entre o discurso e a prática na gestão da QVT. Esta distância pode ser percebida na ausência de "poderes" hierárquicos e controles de retorno visíveis na estrutura. No entanto, pode-se deduzir sobre a presença de mobilização operacional para atender estas demandas através do número de funcionários envolvidos e medidas de controle descrita. Todas estas empresas têm obrigações legais muito explícitas na legislação de Saúde e Segurança e a maioria delas não as associa à QVT. Se houvesse esta associação as exigências legais poderiam representar um ganho operacional e gerencial importante na visão da QVT.

Quanto ao foco estratégico, acreditamos que ele se mostrou presente de forma muito tímida quando associado à QVT, à imagem da empresa e à continuidade do negócio. 


\subsubsection{Tipos de gestão}

Para identificar as variáveis que mais contribuíram para a caracterização dos tipos de gestão, foi feita análise discriminante, com as respostas dos empregados. Os resultados da análise discriminante (Stepwise) encontram-se detalhados a seguir:

\begin{tabular}{|c|c|c|c|c|c|}
\hline Variável & Ordem de entrada & F aproximado & Grupo 1 & Grupo 2 & Grupo 3 \\
\hline & & & & & \\
\hline $\mathrm{P} 121$ & 2 & 32.520 & 0,3135 & 0,1297 & 0,4151 \\
\hline P122 & 8 & 18.111 & 0,1705 & 0,3876 & 0,4086 \\
\hline $\mathrm{P} 123$ & 5 & 23.442 & 0,1892 & $-0,2304$ & 0,0286 \\
\hline $\mathrm{P} 125$ & 9 & 16.998 & $-0,1001$ & $-0,1757$ & $-0,0038$ \\
\hline P126 & 6 & 21.462 & 0,1827 & 0,2598 & 0,3913 \\
\hline $\mathrm{P} 127$ & 7 & 19.587 & 1,8001 & 1,4316 & 1,4877 \\
\hline $\mathrm{P} 141$ & 4 & 23.089 & $-0,1307$ & 0,2866 & $-0,1633$ \\
\hline $\mathrm{P} 142$ & 10 & 15.852 & $-0,0855$ & 0,0606 & 0,0520 \\
\hline $\mathrm{P} 144$ & 1 & 39.232 & $-0,2002$ & 0,1286 & $-0,1545$ \\
\hline $\mathrm{P} 146$ & 3 & 26.700 & $-0,2299$ & $-0,0375$ & $-0,0729$ \\
\hline constante & & & $-9,3441$ & $-9,4882$ & $-10,6456$ \\
\hline
\end{tabular}

O grupo 1 tem sua função de classificação, de acordo com a tabela,

$$
\begin{aligned}
& y=-9,3441+0,3135 \mathrm{P} 121+0,1705 \mathrm{P} 122+0,1892 \mathrm{P} 123+\ldots \\
& -0,2299 \mathrm{P} 146
\end{aligned}
$$

O grupo 2:

$\underline{y}=-9,4882+0,1297 \mathrm{P} 121+0,3876 \mathrm{P} 122-0,2304 \mathrm{P} 123+\ldots \ldots$

$-0,0375$ P146 
De modo semelhante para o grupo 3:

A observação foi atribuída ao grupo cuja função de classificação obtenha o maior valor.

Assim, obteve-se a matriz de classificação

\begin{tabular}{|c|c|c|c|c|}
\hline Grupo & \% correto & 1 & 2 & 3 \\
\hline \hline 1 & 69.7 & 92 & 11 & 29 \\
\hline \hline 2 & 65.9 & 6 & 54 & 22 \\
\hline 3 & 65.1 & 25 & 28 & 99 \\
\hline Total & 66.9 & 123 & 93 & 150 \\
\hline
\end{tabular}

Com apenas 10 variáveis, foram atingidos com o modelo estimado, $70 \%$ de alocações corretas nos três grupos de variáveis de empregados. Estas são, em sua maioria, de âmbito biológico e social, o que leva a concluir que a estrutura da unidade certificada se acha refletida nestas variáveis.

Outras variáveis também se comportaram de maneira diferenciada nos grupos, porém não se configuraram relevantes para discriminação.

Pela análise de variância de um fator, pôde-se observar que as questões relativas a processos e tecnologia, comitês de decisão, ausência da burocracia, rotinas de pessoal, convênio médico, recrutamento e seleção, camaradagem, clima e salário não se diferenciam por tipo de gestão da qualidade de vida, com $95 \%$ de confiança.

Ainda, de acordo com as funções discriminantes, pode-se perceber que o ambulatório está negativamente associado, enquanto convênios (farmácias, 
supermercado etc.) e cesta básica estão positivamente relacionados ao grupo 2 , ocorrendo o oposto em reação aos grupos 1; aleatório e 3; estruturado.

Uma das possíveis razões para tal fato pode ser o ramo de atividade - quatro unidades certificadas entre oito do grupo 2; reativo, são do ramo químico/produtos químicos, enquanto nos outros grupos a distribuição não se encontra concentrada em nenhuma atividade.

Quanto ao grupo de empresas do tipo 3; gestão estruturada, as seguintes variáveis, entre as mais discriminatórias, têm média mais elevada: SIPATs, Riscos - PPRA, Ambulatório, Ginástica e Refeições, todas relativas a aspectos de saúde e atendimento de necessidades biológicas.

Ao comparar este resultado com a equação da regressão múltipla relativa à gerência de recursos humanos, notou-se que a única variável em comum é ambulatório. Daí se conclui que quanto melhor a estrutura da unidade certificada, melhor é o ambulatório (fazendo uma ressalva: uma correlação negativa no grupo 2; reativo), sendo tal ocorrência transparente aos olhos dos empregados. No entanto, não se pode repetir a mesma análise para a gestão do clima organizacional, que só tem correlação com as ações da gerência de recursos humanos.

Ao analisar a distribuição conjunta dos empregados, de acordo com a estrutura da unidade certificada e os conglomerados a que pertencem, não se pode concluir pela dependência desses dois critérios.(estrutura e análise de conglomerados).

Dessa maneira, a diretoria responsável terá um peso de 1/8, P62 um peso de 1/13, P63 um peso de 1/9, e assim por diante.

Computando todas as presenças com seu peso relativo, obteve-se um índice de estrutura de QVT para cada unidade certificada da amostra. De acordo com a 
média e o desvio-padrão (e coeficiente de variação de $67 \%$ ), foi possível segmentar as unidades certificadas em três níveis, alterando a alocação das unidades certificadas 6 e 17 para o superior imediato, de modo que a forma se torna-se mais coerente.

\begin{tabular}{|c|c|c|}
\multicolumn{1}{c}{ média $=6,0$} & $\begin{array}{c}\text { Limite Inferior } \\
(\times 10)\end{array}$ & $\begin{array}{c}\text { Limite superior } \\
(\times 10)\end{array}$ \\
\hline Grupo 1 - estruturado & 0 & 4 \\
\hline Grupo 2 - reativo & 4 & 8 \\
\hline Grupo 3 - aleatório & 8 & 16 \\
\hline
\end{tabular}

Esses grupos foram compostos com base no estágio de gestão, com indicadores de estruturação hierárquica, pessoal alocado, aporte financeiro, medidas de resultados e associação com as ações para certificação ISO 9000. Suas diferenciações básicas estão na Figura 3.4., a seguir. 


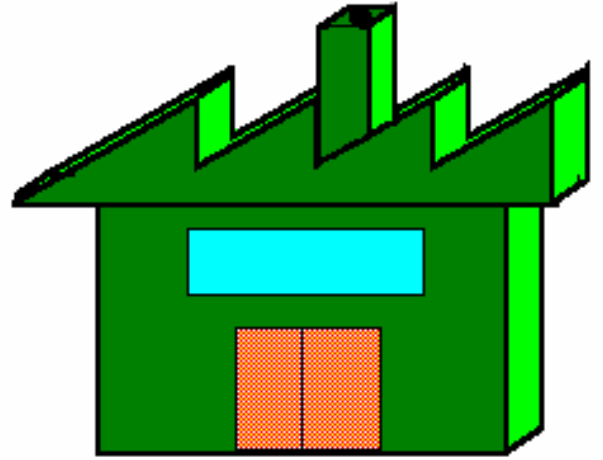

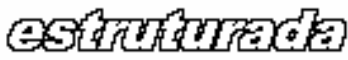

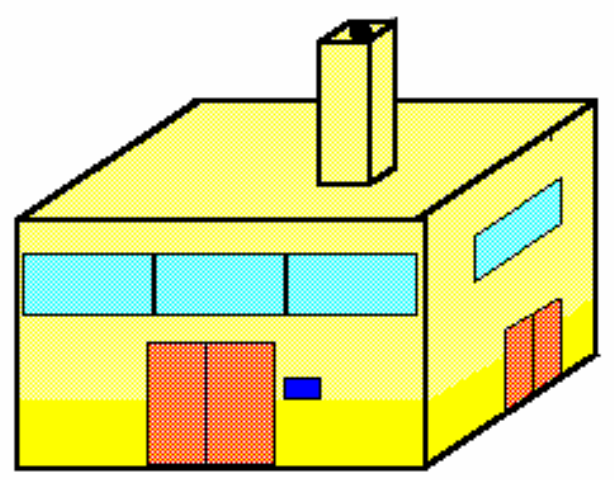

Areatra

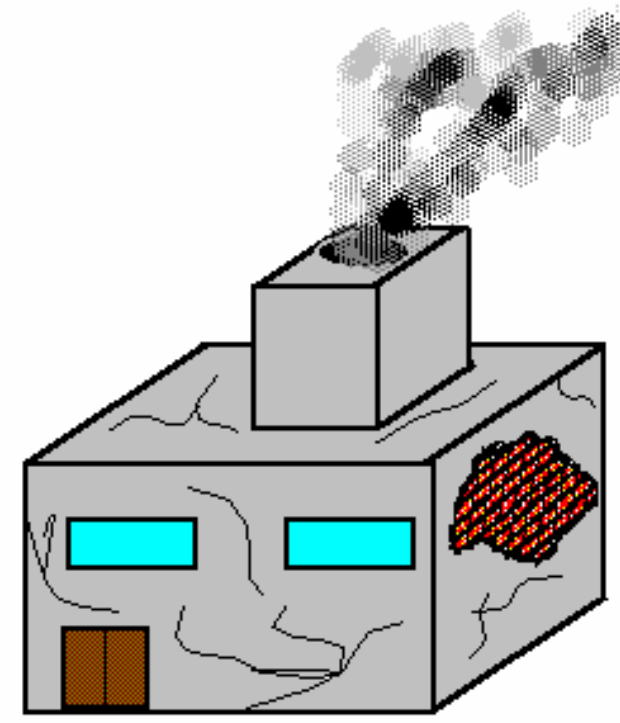

Alloetiontes
Estruturada: Os programas e ações de qualidade de vida no trabalho são realizados dentro de um estrutura organizacional formalizada. Possui diretoria responsável, valoriza QVT para a política de negócios da organização, inclusive com medidas orçamentárias e de acompanhamento das atividades. Atua claramente sobre programas de saúde e segurança, ginástica laboral e refeições.

Reativa: Os programas e ações de qualidade de vida no trabalho possuem áreas e profissionais específicos envolvidos, embora não apresentem nível estratégico de importância na estrutura da empresa. $O$ ambulatório não gera satisfação quanto ao atendimento aos empregados. $\mathrm{O}$ fornecimento de cesta básica e os convênios com farmácias e supermercados têm bons níveis de satisfação por parte dos empregados.

Aleatória: Nestas empresas as ações e programas de qualidade de vida no trabalho são realizadas de forma informal sem avaliação visível e gerenciamento específico. A ação que mais se destaca é a existência do ambulatório médico, que é visto de forma satisfatória por parte dos empregados. A importância da qualidade de vida no trabalho é relatada como importante para a empresa, mas não há esforço gerencial estruturado.

Figura 3.4 Tipos de Gestão 
Tabela 3.21 Tipos de gestão segundo o ramo de atividade

\begin{tabular}{|l|l|l|l|l|}
\hline \multicolumn{1}{|c|}{ Ramo de atividade } & \multicolumn{1}{|c|}{$\begin{array}{c}\text { Grupo 1, } \\
\text { aleatório }\end{array}$} & \multicolumn{1}{c|}{$\begin{array}{c}\text { Grupo 2, } \\
\text { reativo }\end{array}$} & \multicolumn{1}{c|}{$\begin{array}{c}\text { Grupo 3, } \\
\text { estruturado }\end{array}$} \\
\hline Eletroeletrônicos & 4 & $2(16,24)$ & $1(3)$ & $1(21)$ \\
\hline Equipamentos de transporte & 3 & $2(10,12)$ & $1(1)$ & 0 \\
\hline Fabricação de metal primário & 2 & 0 & $1(1)$ & $1(25)$ \\
\hline Instrumentos de medição & 2 & $1(7)$ & 0 & $1(9)$ \\
\hline $\begin{array}{l}\text { Máq. industriais e de } \\
\text { Computação }\end{array}$ & 4 & $1(14)$ & 0 & $3(2,3,13,22)$ \\
\hline $\begin{array}{l}\text { Metais (exceto para } \\
\text { transporte) }\end{array}$ & 2 & 0 & $1(20)$ & $1(4)$ \\
\hline Produtos de tecelagem & 1 & $1(11)$ & 0 & 0 \\
\hline Químicos e produtos químicos & 7 & $1(23)$ & $4(6,8,17,18)$ & $2(5,19)$ \\
\hline \multicolumn{1}{|c|}{ Totais } & 26 & 8 & 8 & 9 \\
\hline
\end{tabular}

Obs.: Os números entre parênteses referem-se ao número de empresas.

A distribuição das unidades segundo o ramo de atividade aponta concentração de indústrias químicas de gestão reativa. O ramo químico é um dos mais exigidos em termos de legislação e controle de riscos ambientais. Esta característica talvez tenha influenciado a forma de as empresas se organizarem para a qualidade de vida, isto é, atender as que é determinado legalmente ou por outros tipos de pressão, deixando para segundo plano ações mais educativas e de promoção integrada do bem-estar dos empregados.

A maior concentração de unidades de gestão estruturada está nas manufaturas de máquinas industriais e de computação. Excetuando-se uma delas, todas as outras são empresas novas e voltadas para o competitivo mercado da informática, com empregados mais novos e qualificados. Provavelmente este seja 
um fator importante para a presença de dados mais consolidados da Gestão da Ações e Programas de Qualidade de Vida no Trabalho.

Quanto às instituições certificadoras, cinco empresas $(20 \%$ do total das manufaturas) do tipo 2; gestão reativa, foram certificadas pela $A B S / Q E$. A ABS/QE certificou dez do total das unidades (40\%); portanto, é esperada sua maior porcentagem de participação nos dados da amostra. A Tabela3.22 detalha todas as distribuições entre tipo de gestão e instituição certificadora.

Tabela 3.22 Tipo de gestão comparado com instituições certificadoras

\begin{tabular}{llllllllll}
\hline & ABS/ & BSI & BVQI & DWV & INMETRO & RWTUV & VANZI & VANZI & Totais \\
& QE & & & & & ABS/QE & DQS & \\
\hline Aleatória & 3 & 0 & 2 & 1 & 0 & 0 & 1 & 1 & 8 \\
Reativa & 5 & 1 & 1 & 0 & 0 & 1 & 0 & 0 & 8 \\
Estruturada & 2 & 0 & 2 & 2 & 2 & 0 & 0 & 1 & 9 \\
\multicolumn{1}{r}{ Totais } & 10 & 1 & 5 & 3 & 2 & 1 & 1 & 2 & 25 \\
\hline
\end{tabular}

$\left(^{*}\right)$ A unidade certificada pela VCIEE respondeu em branco os dados sobre gestão de QVT

Com o objetivo de determinar quais variáveis independentes mais contribuem para a discriminação entre os grupos estruturais, foi realizada uma análise discriminante. O objetivo é indicar quais variáveis de avaliação dos empregados refletem-se na estrutura da empresa. 


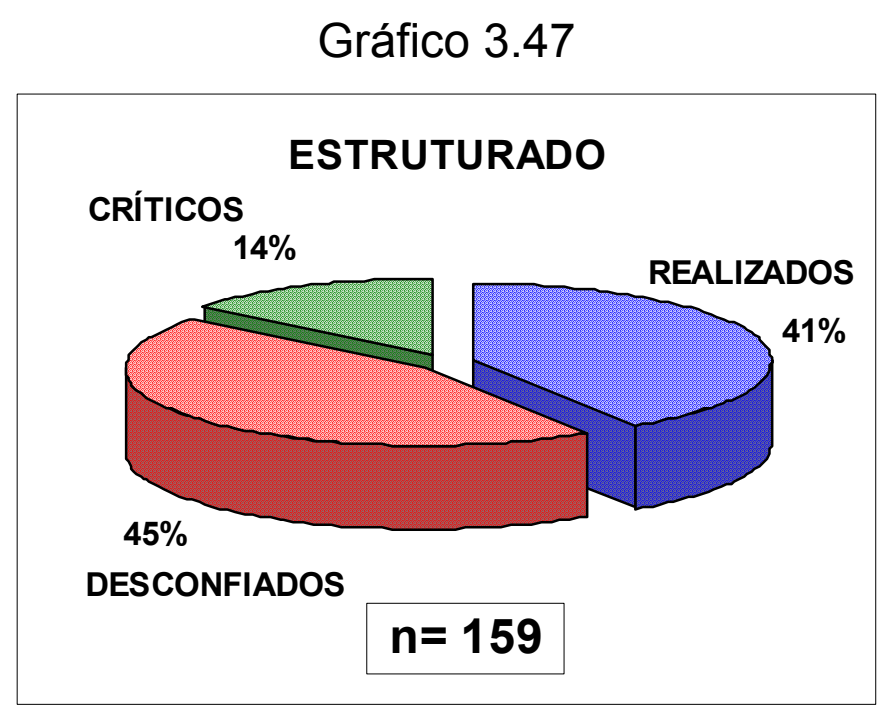

Gráfico 3.48

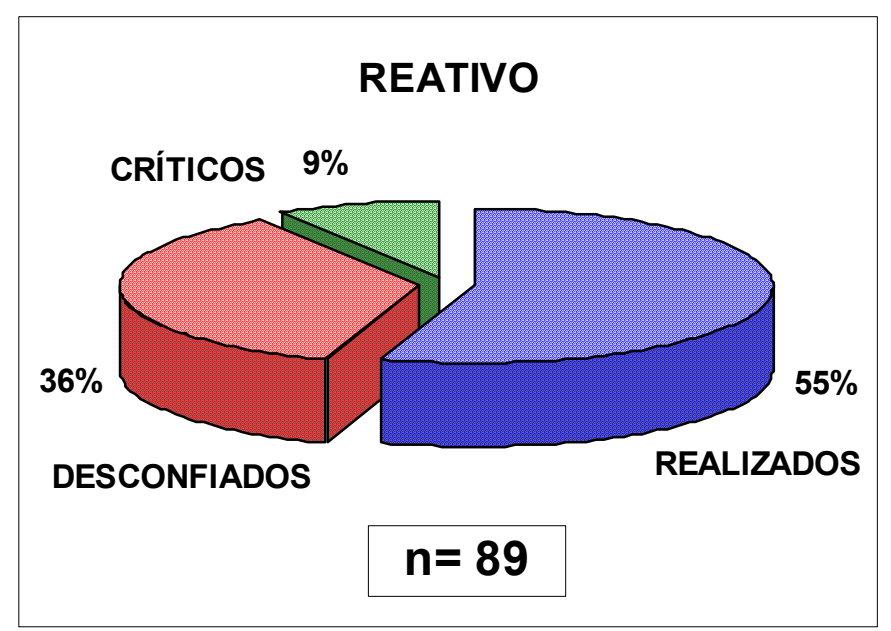

Gráfico 3.49 


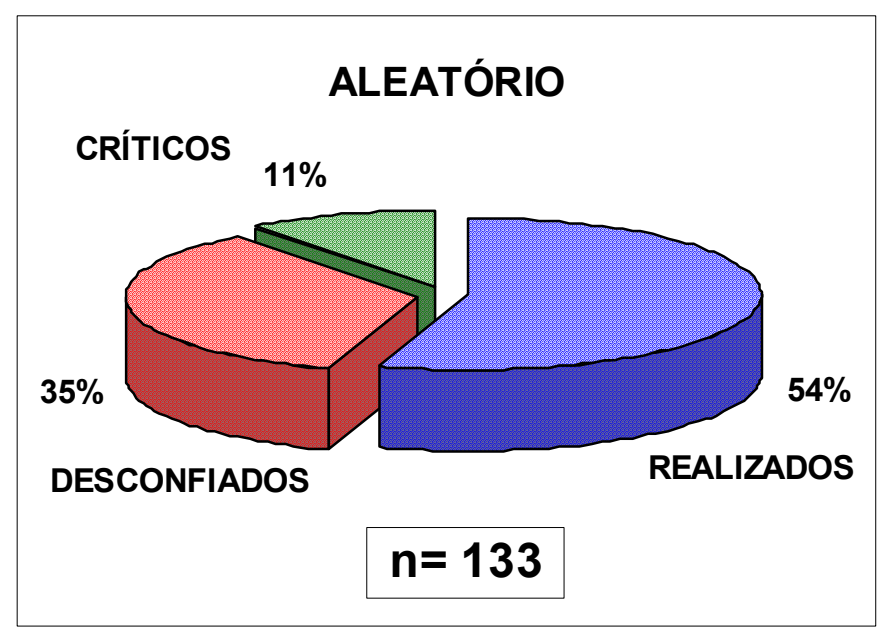

Para avaliação do grau de satisfação dos empregados necessário levar em conta o nível de estrutura organizacional de QVT da unidade certificada e o nível hierárquico do funcionário, já que esta é uma variável com significativo grau dos associação com os perfis de funcionários. 


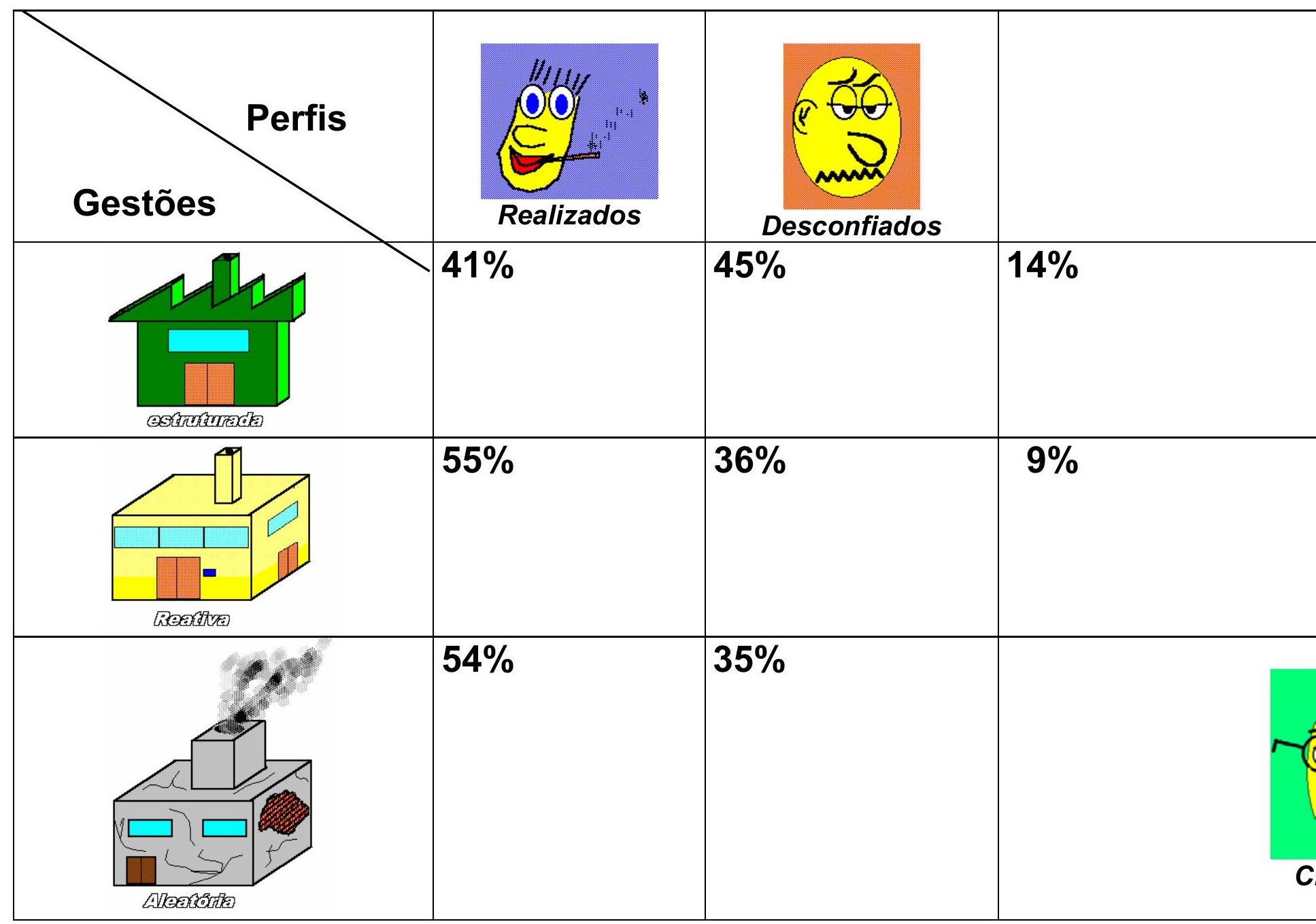




\section{CONCLUSÕES}

O estudo das possíveis relações que se estabelecem entre o esforço da empresa e as respostas de satisfação dos empregados, a partir de indicadores empresariais de qualidade de vida e as conclusões aqui descritas estão embasadas em pilares fundamentais: a revisão conceitual e os conceitos incorporados, a experiência adquirida durante os procedimentos de campo e a análise qualitativa e estatística dos resultados.

Os resultados do estudo de campo serão analisados por tópicos associados ao desenho do problema, na seguinte ordem:

- Comparações entre esforço da empresa e satisfação dos empregados.

- Significados e representação social entre as gerências de recursos humanos e os empregados.

- Tipos de gestão de qualidade de vida no trabalho das empresas.

- Atitudes e perfis de satisfação dos empregados.

- Fatores de qualidade de vida no trabalho dos empregados e das gerências de recursos humanos.

- Pertinência da abordagem biopsicossocial.

As comparações entre esforço da empresa e satisfação dos empregados demonstraram que existem prováveis relações entre esforço e satisfação especialmente quando as ações e os programas de qualidade de vida no trabalho se relacionam com critérios biológicos e critérios sociais. 
Os critérios biológicos foram representados com maior intensidade pelos serviços de ambulatório e convênio médico. Eles refletem a expectativa de atendimento à saúde do trabalhador. Nesses programas, existe equilíbrio entre o esforço da empresa e a satisfação dos empregados. Já quanto aos critérios sociais compostos por programas de atividades de lazer, atendimento a filhos, creches e financiamento de cursos externos, não existe concordância entre o esforço declarado pela empresa e a satisfação percebida dos empregados. As empresas consideram que o esforço dispendido nestes programas é bom, mas os empregados não se sentem satisfeitos. Esses critérios demonstram a necessidade de as empresas diagnosticarem previamente demandas de qualidade de vida no trabalho antes de criarem programas que não atrativos para a cultura específica da empresa e de seus empregados, clientes destes programas.

Os significados e representação social entre as gerências de recursos humanos e os empregados obtidos a partir da análise das escolhas do significado de qualidade de vida no trabalho nos dois segmentos, observou-se que são diferentes os conceitos entre eles. As gerências compreendem qualidade de vida no trabalho como realização pessoal, enquanto os empregados têm como significado mais diferenciador de qualidade de vida a saúde e a segurança (provavelmente associada a estabilidade de emprego). Entre os diferentes níveis hierárquicos observou-se que também existem diferentes representações sociais para qualidade de vida no trabalho, dependendo do nível hierárquico. A direção valorizou mais a realização pessoal e a confiança como conceito de qualidade de vida. As supervisões valorizaram realização pessoal e segurança, o pessoal da produção saúde, segurança e responsabilidade. A palavra responsabilidade também teve escolha significativa para a direção.

A escolha da gestão de recursos humanos para realização pessoal como qualidade de vida no trabalho, pode estar relacionada à posição hierárquica que ocupam, à sua formação e às expectativas de um estilo de vida mais realizador e menos frustrante do que à excessiva 
pressão a que estão submetidos. Por outro lado, as respostas dos empregados, especialmente da produção, podem ser estar refletindo necessidade de sobrevivência. Essas escolhas enquadram-se no modelo de Hierarquia de Necessidades de Maslow nos níveis de necessidades básicas e de auto-realização.

Os tipos de gestão de qualidade de vida no trabalho identificados com base nos elementos da estrutura organizacional, foram identificados três tipos de gestão para ações e programas de qualidade de vida no trabalho. As empresas pesquisadas apresentam gestão estruturada, aleatória ou reativa. No entanto, não houve diferenciação significativa de satisfação em função da estrutura. Não é suficiente ter estrutura disponível, mas é necessário utilizar a capacidade de gestão para o reconhecimento dos indicadores que geram maior satisfação dos empregados, especialmente, por meio de diagnósticos participativos.

Nas atitudes e perfis de satisfação dos empregados existem comportamentos típicos nos empregados que puderam ser identificados em realizados, desconfiados e críticos. Esses comportamentos estão mais associados a atitudes que podem ser expressas em diferentes momentos da autopercepção dos empregados associados a ações por eles valorizadas.

A satisfação demonstrada pelo perfil dos realizados surpreendeu, já que se esperava número mais expressivo de perfis críticos e desconfiados, decorrentes da grande pressão para certificação e recertificação, a que vivem submetidos. Considera-se, no entanto, que o atual mercado de trabalho é recessivo e as manifestações de insatisfação podem estar mais contidas. Por isso, os empregados podem ter elegido uma atitude politicamente correta para a preservação de sua imagem na empresa. A associação entre tipo de gestão e perfil dos empregados só é mais claramente percebida em função do nível hierárquico.

Os fatores de qualidade de vida no trabalho dos empregados e das gerências de recursos humanos obtidos a partir de análise fatorial apresentam um conjunto de novos critérios de análise da qualidade de vida no trabalho. Para o segmento dos empregados foram encontrados 
os

seguintes fatores: atuação organizacional, atendimento a necessidades biológicas, inclusão social e prestação de serviços. Na análise dos dados referentes ao esforço da empresa encontramos os fatores: imagem da empresa, desenvolvimento profissional, saúde e ética, demandas legais e administração de recursos humanos. Estes fatores, também considerados critérios, sinalizam onde ajustar metas em recursos humanos e não só para qualidade de vida.

A abordagem biopsicossocial permitiu analisar o comportamento organizacional de forma mais abrangente do que a tradicional, que apresenta forte tendência de atuar apenas sobre fatores de saúde e segurança. Com o critério organizacional foi possível identificar a importância que a variável imagem tem para os dois segmentos. A valorização da imagem da empresa apareceu associada aos serviços de saúde. Estes dois indicadores revelaram-se diferenciadores da estrutura de gestão das empresas.

A metodologia de estudo de campo mostrou-se eficaz no sentido de garantir conhecimento das condições ambientais dos pesquisados durante o autopreenchimento dos questionários.

Os questionários diferenciados para gerência de recursos humanos e empregados de todos os níveis hierárquicos, mas complementares em termos de foco de ação da empresa e expectativa dos empregados, foi de fácil compreensão e tempo de aplicação rápido. As escalas de zero a dez foram adequadas para o perfil sociofuncional bastante heterogêneo dos pesquisados.

A análise dos resultados organizada de forma a possibilitar crescente complexidade de dados estatísticos foi rica e ratificou indícios surgidos na análise exploratória através dos tratamentos estatísticos de análise fatorial e conglomerados. A classificação dos tipos de gestão foi feita com base em uma amostra pequena, por isso, seria interessante ampliá-la para confirmação dos grupos discriminados. 
Dentre as contribuições gerais da pesquisa foi possível identificar características das ações de qualidade de vida mais valorizadas e que geram bem-estar num ambiente de certificação ISO 9000.

Quanto as respostas para indicadores empresariais, foi possível discriminar indicadores que permitem enxergar com maior objetividade as demandas de esforço empresarial e satisfação dos empregados.

Reconhecemos as diferentes possibilidades da manifestação de atitudes: realizadas, críticas ou desconfiadas, como medidas de qualidade da satisfação dos empregados.

Do ponto de vista da gestão, foram obtidos elementos da estrutura organizacional para ampliar a visão das ações de Qualidade de Vida no Trabalho como ferramenta gerencial diferenciada para a integração e o desenvolvimento organizacional.

Observou-se que as ações e os programas de caráter obrigatório não podem ser subestimados, do ponto de vista da gestão de QVT. Ambulatório, Semanas Internas de Prevenção de Acidentes - SIPATs - devem fazer parte das ferramentas de gestão das empresas e não apenas ser tratados como eventos obrigatórios. Esses indicadores foram os mais associados à satisfação do que as definições de poder e responsabilidades. Esta valorização pode permitir o aprofundamento da visão de benefícios assistenciais na direção da responsabilidade social.

Finalmente, os dados da pesquisa demonstraram a importância de tratar a gestão empresarial da qualidade de vida de maneira mais integradora, incluindo-se a imagem da unidade certificada e autopercepção de qualidade de vida no trabalho. É necessário expandir a compreensão da prática da Qualidade de Vida no Trabalho, identificando-se novas abordagens, que viabilizem ações com foco no cliente das ações e programas de QVT. 


\section{LIMITAÇÕES DO ESTUDO}

Os dados desta pesquisa não devem ser generalizados, mas são informativos em termos de potência e tipos de comportamentos das pessoas diante dos indicadores selecionados, embora haja subjetividade nas respostas, e os dados da gerência de recursos humanos tenham sido restritos às informações de uma pessoa.

Os elementos examinados para a composição dos tipos de gestão precisariam ser repensados para buscar discriminações mais evidentes entre satisfação dos empregados e estrutura organizacional. Foi utilizado como critério elementos estruturais de gestão de uma atividade. À medida em que se expandisse esta análise para aspectos mais participativos, os dados de eficácia da gestão teriam um enfoque mais dinâmico.

Algumas variáveis poderiam ter sido incorporadas, como demandas por moradia, deslocamento físico, dificuldades diante das novas exigências. Estas variáveis ampliariam as contribuições do estudo.

Uma vez acertada a coleta de dados e estando na empresa a receptividade foi positiva. Por isso, seria pertinente uma discussão do tema de forma menos estruturada. Algumas vezes, foram verbalizados outros dados da história da empresa e das pessoas que seriam bastante contributivos sobre o momento que as pessoas estão vivendo, no que se refere a pressões e respostas de qualidade de vida.

\section{NOVAS POSSIBILIDADES NESTA LINHA DE PESQUISA}

Gestão participativa e qualidade de vida no trabalho. Participação em comitês parece ser o grande desafio para a gerência de recursos humanos. O indicador salário apareceu com satisfação moderada, mas nas respostas abertas surgiu com alta freqüência. A gestão participativa, que aparece como desafio das metas gerenciais desejadas e atingidas, poderia ser 
explorada mais profundamente. Os comitês de participação podem representar o canal de comunicação necessário para maior assertividade na geração de resultados de satisfação e até maior facilidade nos procedimentos de recertificação.

Endomarketing e certificação ISO 9000. A certificação cria um ambiente organizacional de mobilização, gera satisfação dos empregados com a imagem da empresa. Pode-se realizar estudo específico entre a variável imagem da empresa (endomarketing), satisfação dos empregados e resultados na manutenção dos requisitos da Certificação ISO 9000.

Aqui, concluímos nossa apresentação do trabalho de pesquisa, com a certeza de que a questão da qualidade de vida no trabalho tem significados importantes para a gestão das empresas e o bem-estar das pessoas. Esperamos que as contribuições ora apresentadas sejam duradouras e despertem novas linhas de pesquisa, especialmente, as relativas aos desafios de alinhar a valorização da condição e do pleno desenvolvimento humano ao posicionamento estratégico e competente das organizações empresariais. 
ANEXO 1

\subsection{MODELO DA CARTA E QUESTIONÁRIO PARA OS EMPREGADOS}

São Paulo, abril de 1996

Aos

Participantes da Pesquisa sobre Qualidade de Vida no Trabalho

\section{Ref: INFORMAÇÕES SOBRE A PESQUISA DE QUALIDADE DE VIDA NO TRABALHO}

Prezado senhor (a)

Vimos solicitar sua colaboração no levantamento de dados para a pesquisa acadêmica que estamos realizando com o objetivo de identificar e analisar a dinâmica das empresas no que se refere à Qualidade de Vida no Trabalho, visando à elaboração da Tese de Doutorado a ser apresentada à FEA/USP.

\section{CARACTERÍSTICAS DO ESTUDO:}

\section{Os questionários e quem responderá:}

O levantamento de campo é composto de dois questionários: um para ser preenchido pelo gerente de recursos humanos ou cargo equivalente, outro para ser preenchido por vinte empregados dos níveis da direção, gerência, supervisão e produção da unidade certificada.

As empresas convidadas foram sorteadas dentre as certificadas ISO 9000 até outubro de 1995, de médio porte e da área de manufatura na Região de São Paulo.

\section{A análise dos dados:}

Os dados e conclusões serão apresentados e discutidos em workshops para duas pessoas das empresas participantes, para discutir as informações tabuladas e sua interpretação adequada. Após defendida a Tese de doutorado, será preparada uma síntese dos resultados da pesquisa e enviada a cada empresa respondente.

\section{Confidencialidade:}

Todas as informações de identidade serão preservadas. Os dados totais serão apresentados de forma agregada, no entanto, cada empresa receberá informações comparativas sobre os seus dados com os demais do conjunto das empresas pesquisadas.

Estamos à disposição para esclarecimentos e informações no telefone (011) 833-0573.

\section{Cordialmente}

Prof. Dr. Lindolfo Galvão de Albuquerque

(Orientador)
Profa. Ana Cristina Limongi França

(pesquisadora) 
INDICADORES EMPRESARIAIS DE QUALIDADE DE VIDA NO TRABALHO

Parte 2 - ponto de vista do empregado

Como preencher o questionário:

$1^{0}$ ) Leia cuidadosamente, responda francamente, mas não demore muito em um item.

$2^{\underline{0}}$ ) Todas as questões devem ser assinaladas.

$3^{\underline{0}}$ ) Não pule item, mesmo que ache difícil responder, assinale apenas a alternativa que se adapte melhor à sua opinião.

BLOCO 1 - RESULTADOS INTERNOS DE SATISFAÇÃO EM QVT

1. Atribua notas de 0 a 10 (zero a dez) que expresse a sua SATISFAÇÃO, com a qualidade das ações da sua empresa para a sua Qualidade de Vida no Trabalho:

\section{LEGENDA:}

INSATISFAÇÃO TOTAL ת 1 ת ת
\begin{tabular}{|l|l|l|l|l|l|l|l|l|l|l|}
\hline 0 & 1 & 2 & 3 & 4 & 5 & 6 & 7 & 8 & 9 & 10 \\
\hline
\end{tabular}

N/T= Não existe a ação na empresa, assinale com um $\boldsymbol{X}$, quando for o caso.

\begin{tabular}{|c|c|c|c|c|c|c|c|c|c|c|c|c|}
\hline 1.1.ASPECTOS ORGANIZACIONAIS & $\mathrm{N} / \mathrm{T}$ & \multicolumn{11}{|c|}{ SATISFAÇÃO } \\
\hline 1.1.1. Imagem da empresa junto aos funcionários & & 0 & 1 & 2 & 3 & 4 & 5 & 6 & 7 & 8 & 9 & 10 \\
\hline $\begin{array}{l}\text { 1.1.2. Oportunidade de treinamento e desenvolvimento } \\
\text { profissional }\end{array}$ & & 0 & 1 & 2 & 3 & 4 & 5 & 6 & 7 & 8 & 9 & 10 \\
\hline $\begin{array}{l}\text { 1.1.3. Melhorias nos processos de trabalho e novas } \\
\text { tecnologias }\end{array}$ & & 0 & 1 & 2 & 3 & 4 & 5 & 6 & 7 & 8 & 9 & 10 \\
\hline 1.1.4. Oportunidade de participar de comitês de decisão & & 0 & 1 & 2 & 3 & 4 & 5 & 6 & 7 & 8 & 9 & 10 \\
\hline $\begin{array}{l}\text { 1.1.5. Qualidade dos procedimentos administrativos (ausên- } \\
\text { cia de burocracia) }\end{array}$ & & 0 & 1 & 2 & 3 & 4 & 5 & 6 & 7 & 8 & 9 & 10 \\
\hline $\begin{array}{l}\text { 1.1.6. Atendimento às rotinas de pessoal (registro, pagamen- } \\
\text { tos. documentos. etc.) }\end{array}$ & & 0 & 1 & 2 & 3 & 4 & 5 & 6 & 7 & 8 & 9 & 10 \\
\hline
\end{tabular}

\begin{tabular}{|l|c|c|c|c|c|c|c|c|c|c|c|c|}
\hline \multicolumn{1}{|c|}{ 1.2.ASPECTOS BIOLÓGICOS } & N/T & \multicolumn{5}{|c|}{ SATISFAČ̃̃ } \\
\hline 1.2.1. Qualidade das SIPATS -Sem.de Prev. de Acidentes & & 0 & 1 & 2 & 3 & 4 & 5 & 6 & 7 & 8 & 9 & 10 \\
\hline 1.2.2. Controle dos riscos ergonômicos e ambientais & & 0 & 1 & 2 & 3 & 4 & 5 & 6 & 7 & 8 & 9 & 10 \\
\hline 1.2.3. Atendimento do ambulatório & & 0 & 1 & 2 & 3 & 4 & 5 & 6 & 7 & 8 & 9 & 10 \\
\hline 1.2.4. Atendimento do convênio médico & & 0 & 1 & 2 & 3 & 4 & 5 & 6 & 7 & 8 & 9 & 10 \\
\hline 1.2.5. Oportunidade de realizar ginástica no trabalho & & 0 & 1 & 2 & 3 & 4 & 5 & 6 & 7 & 8 & 9 & 10 \\
\hline 1.2.6. Qualidade das Refeições oferecidas pela empresa & & 0 & 1 & 2 & 3 & 4 & 5 & 6 & 7 & 8 & 9 & 10 \\
\hline 1.2.7. Estado geral de saúde dos colegas e supeiores & & 0 & 1 & 2 & 3 & 4 & 5 & 6 & 7 & 8 & 9 & 10 \\
\hline 1.2 .8$. Qualidade da atuação da CIPAs & & 0 & 1 & 2 & 3 & 4 & 5 & 6 & 7 & 8 & 9 & 10 \\
\hline
\end{tabular}


LEGENDA:

NEUTRA

INSATISFAÇÃO TOTAL 』

$\sqrt{2}$

』 SATISFAÇÃo TOtAL

\begin{tabular}{|l|l|l|l|l|l|l|l|l|l|l|}
\hline 0 & 1 & 2 & 3 & 4 & 5 & 6 & 7 & 8 & 9 & 10 \\
\hline
\end{tabular}

$\mathrm{N} / \mathrm{T}=$ Não existe a ação na empresa, assinale com um $\boldsymbol{X}$, quando for o caso.

\begin{tabular}{|l|c|c|c|c|c|c|c|c|c|c|c|c|}
\hline \multicolumn{1}{|c|}{ 1.3.ASPECTOS PSICOLÓGICOS } & N/T & \multicolumn{5}{|c|}{ SATISFAÇ̃̃O } \\
\hline 1.3.1. Confiança nos critérios de recrutamento e seleção & & 0 & 1 & 2 & 3 & 4 & 5 & 6 & 7 & 8 & 9 & 10 \\
\hline 1.3.2. Forma de avaliação do desempenho do seu trabalho & & 0 & 1 & 2 & 3 & 4 & 5 & 6 & 7 & 8 & 9 & 10 \\
\hline 1.3.3. Clima de camaradagem entre as pessoas & & 0 & 1 & 2 & 3 & 4 & 5 & 6 & 7 & 8 & 9 & 10 \\
\hline 1.3.4. Oportunidade de carreira & & 0 & 1 & 2 & 3 & 4 & 5 & 6 & 7 & 8 & 9 & 10 \\
\hline 1.3.5. Satisfação com o salário & & 0 & 1 & 2 & 3 & 4 & 5 & 6 & 7 & 8 & 9 & 10 \\
\hline 1.3.6. Ausência de interferência na vida pessoal & & 0 & 1 & 2 & 3 & 4 & 5 & 6 & 7 & 8 & 9 & 10 \\
\hline
\end{tabular}

\begin{tabular}{|l|c|c|c|c|c|c|c|c|c|c|c|c|}
\hline 1.4.ASPECTOS SOCIAIS & N/T & \multicolumn{6}{|c|}{ SATISFAÇÃO } \\
\hline $\begin{array}{c}\text { 1.4.1. Qualidade de convênios (farmácia, compras, } \\
\text { supermercado) }\end{array}$ & & 0 & 1 & 2 & 3 & 4 & 5 & 6 & 7 & 8 & 9 & 10 \\
\hline $\begin{array}{c}\text { 1.4.2. Oportunidade para distração (futebol, área de } \\
\text { lazer.excursões, etc.) }\end{array}$ & & 0 & 1 & 2 & 3 & 4 & 5 & 6 & 7 & 8 & 9 & 10 \\
\hline $\begin{array}{c}\text { 1.4.3. Atendimento aos filhos (creche, escola) } \\
\text { 1.4.4. Qualidade da cesta básica }\end{array}$ & 0 & 1 & 2 & 3 & 4 & 5 & 6 & 7 & 8 & 9 & 10 \\
\hline $\begin{array}{c}\text { 1.4.5. Qualidade dos seguros de previdência privada } \\
\text { 1.4.6. Financiamento para cursos externos (faculdade,inglês, } \\
\text { cursos técnicos. profissionalizantes, etc) }\end{array}$ & & 0 & 1 & 2 & 3 & 4 & 5 & 6 & 7 & 8 & 9 & 10 \\
\hline
\end{tabular}

\begin{tabular}{|l|c|c|c|c|c|c|c|c|c|c|c|c|}
\hline \multicolumn{1}{|c|}{ 1.5. OUTRAS AÇÕES DE QVT DA EMPRESA } & \multicolumn{7}{|c|}{ SATISFAÇ̃̃O } \\
\hline 1.5 .1$. & 0 & 1 & 2 & 3 & 4 & 5 & 6 & 7 & 8 & 9 & 10 \\
\hline 1.5 .2$. & 0 & 1 & 2 & 3 & 4 & 5 & 6 & 7 & 8 & 9 & 10 \\
\hline 1.5 .3$. & 0 & 1 & 2 & 3 & 4 & 5 & 6 & 7 & 8 & 9 & 10 \\
\hline
\end{tabular}

\begin{tabular}{|l|c|c|c|c|c|c|c|c|c|c|c|c|}
\hline \multicolumn{7}{|c|}{ 1.6. AÇÕES DE QVT QUE FALTAM NA EMPRESA } & \multicolumn{7}{|c|}{ SATSFAC̃̃ } \\
\hline 1.6 .1$. & 0 & 1 & 2 & 3 & 4 & 5 & 6 & 7 & 8 & 9 & 10 \\
\hline 1.6 .2$. & 0 & 1 & 2 & 3 & 4 & 5 & 6 & 7 & 8 & 9 & 10 \\
\hline 1.6 .3$. & 0 & 1 & 2 & 3 & 4 & 5 & 6 & 7 & 8 & 9 & 10 \\
\hline
\end{tabular}

BLOCO 2- QUALIDADE DE VIDA NO TRABALHO

Neste bloco queremos saber sua opinião sobre o que significa Qualidade de Vida no Trabalho para você.Indique por ordem de importância TRESS PALAVRAS que expressem qualidade de vida no trabalho de acordo com a LEGENDA:

LEGENDA: $1=$ mais importante

$2=$ segunda mais importante

$3=$ terceira mais importante

confiança

humanismo

amor

outra: segurança

saúde

realização pessoal paz

competitividade amizade investimento

ausência de acidentes

responsabilidade 
BLOCO 3 - ESTADO PESSOAL DE QVT

Você está satisfeito com sua Qualidade Pessoal de vida? Dê uma nota de zero a dez - DE ACORDO COM A LEGENDA - para os aspectos de BEM-ESTAR indicados no quadro:

\section{LEGENDA:}

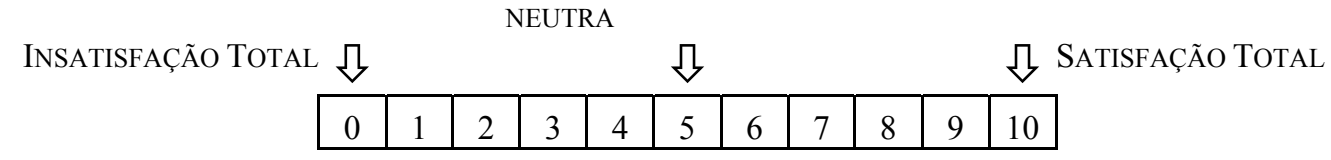

\begin{tabular}{|l|c|c|c|c|c|c|c|c|c|c|c|c|}
\hline 3.1.OPINIÃO PESSOAL & \multicolumn{7}{|c|}{ SATISFAÇ̃̃O } \\
\hline $\begin{array}{l}\text { 3.1.2. Sensação de bem-estar no trabalho } \\
\text { 3.1.2. Estado geral de tensão(stress) pessoal }\end{array}$ & 0 & 1 & 2 & 3 & 4 & 5 & 6 & 7 & 8 & 9 & 10 \\
\hline $\begin{array}{c}\text { 3.1.3. Satisfação com o seu modo próprio de viver o dia a } \\
\text { dia (estilo de vida) }\end{array}$ & 0 & 1 & 2 & 3 & 4 & 5 & 6 & 7 & 8 & 9 & 10 \\
\hline $\begin{array}{c}\text { 3.1.4.Adequação das Ações de QVT da sua empresa para as } \\
\text { suas necessidades pessoais }\end{array}$ & 0 & 1 & 2 & 3 & 4 & 5 & 6 & 7 & 8 & 9 & 10 \\
\hline \begin{tabular}{c} 
3.1.5. Importância da QVT para o resultado do seu trabalho \\
\hline
\end{tabular} & 0 & 1 & 2 & 3 & 4 & 5 & 6 & 7 & 8 & 9 & 10 \\
\hline
\end{tabular}

Assinale com um $\mathrm{X}$ sobre as suas seguintes OCORRÊNCIAS DE SAÚDE-DOENÇA nos últimos 12 meses?

\begin{tabular}{|c|c|c|c|}
\hline 3.2.OCORRÊNCIAS & & & \\
\hline 3.2.1.Utilizou remédios para dores específicas? & ( ) NÃO & ( ) SIM & Comentários: \\
\hline 3.2.2.Sofreu internação em hospital? & ( ) NÃO & ( ) SIM & \\
\hline 3.2.3.Foi atendido em pronto-socorro & ( ) NÃO & ( ) SIM & \\
\hline 3.2.4.Utilizou o convênio médico & ( ) NÃO & ( ) SIM & \\
\hline 3.2.5.Utilizou o serviço de saúde da empresa & ( ) NÃO & ( ) SIM & \\
\hline 3.2.6.Faltou ao trabalho por mal-estar ou doença? & ( ) NÃO & ( ) SIM & \\
\hline
\end{tabular}

3.3. Escreva no quadro abaixo a melhoria mais importante que a empresa fez para a Qualidade de Vida no Trabalho:

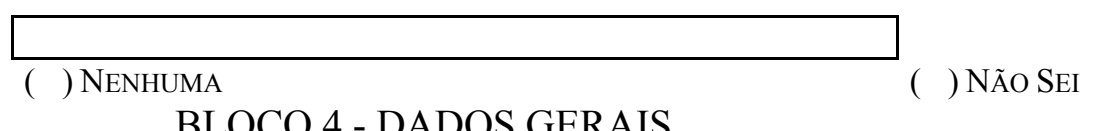

Você acredita que esta pesquisa poderá ser utilizada para as ações de Qualidade de Vida no Trabalho da sua empresa?

$$
\text { NÃO ( ) SIM ( ) }
$$

Comentários e sugestões:

\begin{tabular}{|l|l|l|l|}
\hline $\begin{array}{l}\text { Cargo } \\
\text { atual: }\end{array}$ & & \multicolumn{1}{l|}{ Idade: } & $\begin{array}{l}\text { Sexo: ( )Fem. ( } \\
\text { )Masc }\end{array}$ \\
\hline Nível hierárquico: & Faixa salarial: & Escolaridade: & $\begin{array}{l}\text { Número de dependentes: } \\
\left(\begin{array}{l}\text { ( )nenhum } \\
\hline\end{array}\right.\end{array}$ \\
\hline
\end{tabular}




\begin{tabular}{|c|c|c|c|}
\hline $\begin{array}{l}\text { ( )produção } \\
\text { ( )supervisão } \\
\text { ( )gerência } \\
\text { ( )direção } \\
\text { sindicalizado? } \\
\text { ( ) Não } \\
\text { ( ) Sim }\end{array}$ & $\begin{array}{l}(\quad) \text { até } \mathrm{R} \$ 500 \\
(\quad) \mathrm{R} \$ 501 \text { a } \mathrm{R} \$ 1.000 \\
(\quad) \mathrm{R} \$ 1001 \text { a } \mathrm{R} \$ 3.000 \\
(\quad) \mathrm{R} \$ 3001 \text { a } \mathrm{R} \$ 5.000 \\
(\quad) \text { acima de } \mathrm{R} \$ 5.001\end{array}$ & 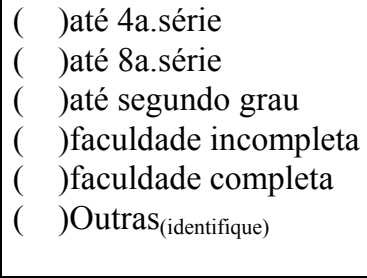 & $\begin{array}{ll}( & \text { )um } \\
( & \text { dois } \\
( & \text { )três } \\
( & \text { )quatro } \\
( & \text { cinco } \\
( & \text { ) mais de cinco }\end{array}$ \\
\hline
\end{tabular}




\title{
ANEXO 1 \\ 1.1 CARTA E QUESTIONÁRIO PARA A GERÊNCIA DE RECURSOS HUMANOS
}

\author{
São Paulo, abril de 1996 \\ $\grave{A}$ \\ Gerência de Recursos Humanos da \\ Unidade Certificada \\ Ref: PESQUISA SOBRE QUALIDADE DE VIDA NO TRABALHO \\ Prezado senhor (a) \\ Vimos solicitar sua colaboração no levantamento de dados para a pesquisa acadêmica que \\ estamos realizando com o objetivo de identificar e analisar a dinâmica das empresas no \\ que se refere à Qualidade de Vida no Trabalho, visando a elaboração da Tese de \\ Doutorado a ser apresentada à FEA/USP.
}

\section{CARACTERÍSTICAS DO ESTUDO:}

Os questionários e quem responderá:

O levantamento de campo é composto de dois questionários: um para ser preenchido pelo gerente de recursos humanos ou cargo equivalente, outro para ser preenchido por vinte empregados dos níveis da direção, gerência, supervisão e produção da unidade certificada.

As empresas convidadas foram sorteadas dentre as certificadas ISO 9000 até outubro de 1995, de médio porte e da área de manufatura na Região de São Paulo.

A análise dos dados:

Os dados e conclusões serão apresentados e discutidos em workshops para duas pessoas das empresas participantes, para discutir as informações tabuladas e sua interpretação adequada. Após defendida a Tese de doutorado, será preparada uma síntese dos resultados da pesquisa e enviada a cada empresa respondente.

Confidencialidade:

Todas as informações de identidade serão preservadas. Os dados totais serão apresentados de forma agregada, no entanto, cada empresa receberá informações comparativas sobre os seus dados com os demais do conjunto das empresas pesquisadas. 0573.

Estamos à disposição para esclarecimentos e informações no telefone (011) 833-

\section{Cordialmente}


Prof. Dr. Lindolfo Galvão de Albuquerque (orientador)
Profa. Ana Cristina Limongi França (pesquisadora) 
INDICADORES EMPRESARIAIS DE QUALIDADE DE VIDA NO TRABALHO

Parte 1: Ponto de Vista do Gerente de Recursos Humanos (ou equivalente)

\section{Como preencher o questionário:}

$\left.1^{\underline{0}}\right)$ Leia cada item, responda francamente, mas não demore muito em um item.

$\left.2^{\underline{0}}\right)$ Os questionários incompletos prejudicarão a análise. Sendo assim, não pule item.

$\left.3^{0}\right)$ Algumas respostas precisam de dados de outros setores, consulte-os.

$4^{\underline{0}}$ ) Quando não houver fonte de dados específica, assinale a alternativa que se adapte melhor.

\section{BLOCO 1 - AÇÕES EMPRESARIAIS EM QVT}

Avalie a INTENSIDADE DO ESFORÇO GERENCIAL (mobilização organizacional, pessoal e finenceira) da sua empresa na Unidade Certificada - nos últimos 12 meses - com relação às ações desenvolvidas. Marque com um $X_{\text {o }}$ esforço equivalente de 0 a 10 (zero a dez), de acordo com a LEGENDA:

\section{LEGENDA:}

ESFORÇO MODERADO

NENHUM ESFORÇO ת
\begin{tabular}{|l|l|l|l|l|l|l|l|l|l|l|}
\hline 0 & 1 & 2 & 3 & 4 & 5 & 6 & 7 & 8 & 9 & 10 \\
\hline
\end{tabular}

N/T= Não existe a ação na empresa, assinale com um $\boldsymbol{X}$, quando for o caso:

\begin{tabular}{|l|c|c|c|c|c|c|c|c|c|c|c|c|}
\hline \multicolumn{1}{|c|}{ 1.1.AÇÕES DE ÊNFASE ORGANIZACIONAL } & N/T & \multicolumn{7}{|c|}{ ESFORÇO } \\
\hline 1.1.1. Marketing da empresa para os funcionários & & 0 & 1 & 2 & 3 & 4 & 5 & 6 & 7 & 8 & 9 & 10 \\
\hline 1.1.2. Programação de Desenvolv. e Treinamento & & 0 & 1 & 2 & 3 & 4 & 5 & 6 & 7 & 8 & 9 & 10 \\
\hline 1.1.3. Melhorias nos processos e tecnologia & & 0 & 1 & 2 & 3 & 4 & 5 & 6 & 7 & 8 & 9 & 10 \\
\hline 1.1.4. Valorização da gestão do tipo participativa & & 0 & 1 & 2 & 3 & 4 & 5 & 6 & 7 & 8 & 9 & 10 \\
\hline $\begin{array}{l}\text { 1.1.5. Melhorias para redução da burocracia } \\
\text { 1.1.6. Organização das rotinas de pessoal (registro, } \\
\text { pagamentos, documentos,etc.) }\end{array}$ & & 0 & 1 & 2 & 3 & 4 & 5 & 6 & 7 & 8 & 9 & 10 \\
\hline
\end{tabular}

\begin{tabular}{|l|c|c|c|c|c|c|c|c|c|c|c|c|}
\hline \multicolumn{1}{|c|}{ 1.2.AÇÕES DE ÊNFASE BIOLÓGICA } & \multicolumn{1}{|c|}{ ESFORC } \\
\hline 1.2.1.SIPAT-Semana Interna de Prev de Acidentes & & 0 & 1 & 2 & 3 & 4 & 5 & 6 & 7 & 8 & 9 & 10 \\
\hline 1.2.2.PPRA-Prog. Prevenção de Riscos Ambientais & & 0 & 1 & 2 & 3 & 4 & 5 & 6 & 7 & 8 & 9 & 10 \\
\hline 1.2.3.Ambulatório & & 0 & 1 & 2 & 3 & 4 & 5 & 6 & 7 & 8 & 9 & 10 \\
\hline 1.2.4.Convênio Médico & & 0 & 1 & 2 & 3 & 4 & 5 & 6 & 7 & 8 & 9 & 10 \\
\hline 1.2.5.Ginástica durante o trabalho & & 0 & 1 & 2 & 3 & 4 & 5 & 6 & 7 & 8 & 9 & 10 \\
\hline 1.2.6.Refeições oferecidas pela empresa & & 0 & 1 & 2 & 3 & 4 & 5 & 6 & 7 & 8 & 9 & 10 \\
\hline
\end{tabular}




\begin{tabular}{|l|l|l|l|l|l|l|l|l|l|l|l|l|}
\hline 1.2.7.PCSMO -Contr. Médico e Saúde Ocupacional & & 0 & 1 & 2 & 3 & 4 & 5 & 6 & 7 & 8 & 9 & 10 \\
\hline 1.2.8.Atuação das CIPAs & & 0 & 1 & 2 & 3 & 4 & 5 & 6 & 7 & 8 & 9 & 10 \\
\hline
\end{tabular}


LEGENDA

ESFORÇO MODERADO

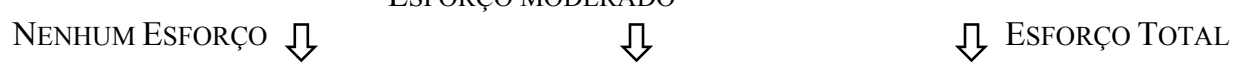

\begin{tabular}{|l|l|l|l|l|l|l|l|l|l|l|}
\hline 0 & 1 & 2 & 3 & 4 & 5 & 6 & 7 & 8 & 9 & 10 \\
\hline
\end{tabular}

N/T= Não existe a ação na empresa, assinale com um $\boldsymbol{X}$ quando for o caso

\begin{tabular}{|l|c|c|c|c|c|c|c|c|c|c|c|c|}
\hline \multicolumn{1}{|c|}{ 1.3.AÇÕES DE ÊNFASE PSICOLÓGICA } & \multicolumn{1}{|c|}{ N/T } & \multicolumn{1}{|c|}{ ESFORÇO } \\
\hline 1.3.1. Critérios de Recrutamento e Seleção & & 0 & 1 & 2 & 3 & 4 & 5 & 6 & 7 & 8 & 9 & 10 \\
\hline 1.3.2. Ferramentas de avaliação de desempenho & & 0 & 1 & 2 & 3 & 4 & 5 & 6 & 7 & 8 & 9 & 10 \\
\hline 1.3.3. Gestão do clima organizacional & & 0 & 1 & 2 & 3 & 4 & 5 & 6 & 7 & 8 & 9 & 10 \\
\hline 1.3.4. Plano de Carreira & & 0 & 1 & 2 & 3 & 4 & 5 & 6 & 7 & 8 & 9 & 10 \\
\hline 1.3.5. Administração de salários & & 0 & 1 & 2 & 3 & 4 & 5 & 6 & 7 & 8 & 9 & 10 \\
\hline 1.3.6. Respeito à vida pessoal dos empregados & & 0 & 1 & 2 & 3 & 4 & 5 & 6 & 7 & 8 & 9 & 10 \\
\hline
\end{tabular}

\begin{tabular}{|c|c|c|c|c|c|c|c|c|c|c|c|c|}
\hline 1.4.AÇÕES DE ÊNFASE SOCIAL & $\mathrm{N} / \mathrm{T}$ & \multicolumn{11}{|c|}{ ESFORÇO } \\
\hline 1.4.1. Convênios (farmácia, supermercado, compras) & & 0 & 1 & 2 & 3 & 4 & 5 & 6 & 7 & 8 & 9 & 10 \\
\hline $\begin{array}{l}\text { 1.4.2. Atividades para o tempo livre (futebol,esportes, } \\
\text { recreação, dominó, eventos, etc.) }\end{array}$ & & 0 & 1 & 2 & 3 & 4 & 5 & 6 & 7 & 8 & 9 & 10 \\
\hline $\begin{array}{l}\text { 1.4.3. Atendimento aos filhos (creche, berçário, } \\
\text { escola, etc.)) }\end{array}$ & & 0 & 1 & 2 & 3 & 4 & 5 & 6 & 7 & 8 & 9 & 10 \\
\hline 1.4.4. Fornecimento de cesta básica & & 0 & 1 & 2 & 3 & 4 & 5 & 6 & 7 & 8 & 9 & 10 \\
\hline 1.4.5. Administração da previdência privada & & 0 & 1 & 2 & 3 & 4 & 5 & 6 & 7 & 8 & 9 & 10 \\
\hline $\begin{array}{l}\text { 1.4.6. Financiamento educação (faculdade, idiomas, } \\
\text { técnicos, profissionalizantes, etc) }\end{array}$ & & 0 & 1 & 2 & 3 & 4 & 5 & 6 & 7 & 8 & 9 & 10 \\
\hline
\end{tabular}

\begin{tabular}{|l|l|l|l|l|l|l|l|l|l|l|l|l|}
\hline 1.5. OUTRAS AçÕES DE QVT QUE A EMPRESA TEM & \multicolumn{10}{|c|}{ ESFORÇO } \\
\hline 1.5 .1$. & 0 & 1 & 2 & 3 & 4 & 5 & 6 & 7 & 8 & 9 & 10 \\
\hline 1.5 .2$. & 0 & 1 & 2 & 3 & 4 & 5 & 6 & 7 & 8 & 9 & 10 \\
\hline 1.5 .3$. & 0 & 1 & 2 & 3 & 4 & 5 & 6 & 7 & 8 & 9 & 10 \\
\hline
\end{tabular}

\begin{tabular}{|l|c|c|c|c|c|c|c|c|c|c|c|}
\hline 1.6. AÇÕES DE QVT QUE FALTAM NA EMPRESA & \multicolumn{10}{|c|}{ ESFORÇO } \\
\hline 1.6.1. & 0 & 1 & 2 & 3 & 4 & 5 & 6 & 7 & 8 & 9 & 10 \\
\hline 1.6.2. & 0 & 1 & 2 & 3 & 4 & 5 & 6 & 7 & 8 & 9 & 10 \\
\hline 1.6 .3$. & 0 & 1 & 2 & 3 & 4 & 5 & 6 & 7 & 8 & 9 & 10 \\
\hline
\end{tabular}

1.7. Indique por ordem de importância TRÊS PALAVRAS que expressem - para você - qualidade de vida no trabalho:

$$
\begin{array}{ll}
\text { LEGENDA: } & 1=\text { MAIS IMPORTANTE } \\
& 2=\text { SEGUNDA MAIS IMPORTANTE } \\
& 3=\text { TERCEIRA MAIS IMPORTANTE }
\end{array}
$$


confiança

humanismo

amor

outra(identifique): segurança

saúde

realização pessoal paz

competitividade

amizade investimento

ausência de acidentes

responsabilidade

\section{BLOCO 2 - ESTADO PESSOAL DE QVT}

Você está satisfeito com sua Qualidade Pessoal de vida? Dê uma nota de zero a dez para os aspectos de BEMESTAR a seguir:

LEGENDA
INEUTRA
INSATISFAÇÃO TOTAL ת
\begin{tabular}{|l|l|l|l|l|l|l|l|l|l|l|}
\hline 0 & 1 & 2 & 3 & 4 & 5 & 6 & 7 & 8 & 9 & 10 \\
\hline
\end{tabular}

\begin{tabular}{|c|c|c|c|c|c|c|c|c|c|c|c|}
\hline 2.1.OPINIÃO PESSOAL & & $\mathrm{S}$ & $\mathrm{A}$ & $\mathrm{T}$ & $\mathrm{I}$ & $\mathrm{S}$ & $\mathrm{F}$ & A & Ç & $\tilde{\mathrm{A}}$ & $\mathrm{O}$ \\
\hline 2.1.1. Sensação de bem-estar no trabalho & 0 & 1 & 2 & 3 & 4 & 5 & 6 & 7 & 8 & 9 & 10 \\
\hline 2.1.2. Estado geral de tensão(stress) pessoal & 0 & 1 & 2 & 3 & 4 & 5 & 6 & 7 & 8 & 9 & 10 \\
\hline 2.1.3. Grau de satisfação com a sua Qualidade de Vida & 0 & 1 & 2 & 3 & 4 & 5 & 6 & 7 & 8 & 9 & 10 \\
\hline 2.1.4. Adequação das Ações de QVT da sua empresa & 0 & 1 & 2 & 3 & 4 & 5 & 6 & 7 & 8 & 9 & 10 \\
\hline 2.1.5. Importância da QVT para o resultado do seu trabalho & 0 & 1 & 2 & 3 & 4 & 5 & 6 & 7 & 8 & 9 & 10 \\
\hline
\end{tabular}

2.2.Assinale com um $X$ sobre as suas seguintes OCORRÊNCIAS DE SAÚDE-DOENÇA nos últimos 12meses?

\begin{tabular}{|c|c|c|c|}
\hline 2.2.OCORRÊNCIAS & & & \\
\hline 2.2.1.Utilizou remédios para dores específicas? & ( ) $\mathrm{NÃO}$ & ( ) SIM & Comentários: \\
\hline 2.2.2.Sofreu internação em hospital? & ( ) NÃO & ( ) SIM & \\
\hline 2.2.3. Foi atendido em pronto-socorro & ( ) NÃO & ( ) SIM & \\
\hline 2.2.4.Utilizou o convênio médico & ( ) $\mathrm{NÃO}$ & ( ) SIM & \\
\hline 2.2.5.Utilizou o serviço de saúde da empresa & ( ) NÃO & ( ) SIM & \\
\hline 2.2.6.Faltou ao trabalho por mal-estar ou doença? & ( ) NÃO & ( ) SIM & \\
\hline
\end{tabular}

\section{BLOCO 3 - QUALIDADE DE VIDA NO TRABALHO \& CERTIFICAÇÃO}

3.1. Considerando o processo de certificação da sua UNIDADE, indique por ordem de importância TRÊS MELHORIAS DE QUALIDADE DE VIDA NO TRABALHO que facilitariam a implantação da ISO 9000 (vide a LEGENDA):

\section{LEGENDA: $1=$ MAIS IMPORTANTE \\ 2= SEGUNDA MAIS IMPORTANTE \\ $3=$ TERCEIRA MAIS IMPORTANTE}

clareza de procedimentos

valorização monetária dos funcionários melhoria do sistema de alimentação desafios de metas para serem superados mais autonomia dos funcionários nas decisões novas atividades culturais e esportivas educação para o trabalho organização geral da empresa contato mais próximo com o cliente realização de ginástica laboral programas de controle de doenças e acidentes novos benefícios para funcionários e familiares outra (identifique): Nenhuma delas 
3.2. Considerando o processo de certificação da sua Unidade, indique por ordem de importância TRÊS OBSTÁCULOS RELACIONADOS À QUALIDADE DE VIDA NO TRABALHO que dificultam a implantação da ISO 9000 (vide a LEGENDA):

processos de produção/tecnologia

pressão dos clientes

condições sócio-econômicas dos funcionários

ausência por licenças médicas

problemas familiares dos funcionários

falta de motivação e interesse

cobrança excessiva de resultados existência de tarefas perigosas

falta de qualificação profissional

preparo da documentação

relacionamento entre os funcionários

ausência de alimentação e repouso adequados

outra (identifique):

nenhuma delas 


\section{BLOCO 4 - PRESSÕES EXTERNAS}

Considere a existência de PRESSÃo EXTERNA para serviços associados à Qualidade de Vida no Trabalho, na sua empresa desde os últimos 12 mêses, assinalando com um X ( )NÃO ou ( ) SIM para a origem apontada:

\begin{tabular}{|c|c|c|}
\hline ORIGEM & Pressão & Externa \\
\hline 4.1. Fiscalização & ( ) )NÃO & ( )SIM \\
\hline 4.1. Sindicatos & ( ) )NÃO & ( )SIM \\
\hline 4.3. Instituições Certificadoras & ( ) )NÃO & ( ) SIM \\
\hline 4.4. Cliente & ( )NÃO & ( ) $)$ SIM \\
\hline 4.5. Matriz/corporação & ( )NÃO & $\overline{(\quad) S I M}$ \\
\hline 4.6. Concorrentes & ( ) )NÃO & ( )SIM \\
\hline 4.7. Outra ${ }_{\text {(identifique): }}$ & ( ) )NÃO & ( ) $)$ SIM \\
\hline
\end{tabular}

Comentários:

\section{BLOCO 5 - QUALIDADE \& QUALIDADE DE VIDA NO TRABALHO}

5.1. Considere neste bloco a porcentagem de empregados que DEVERIAM SER ATINGIDOS E QUE FORAM REALMENTE ATINGIDOS nas ações permanentes ou temporárias de QVT, nos últimos 12 meses, de acordo com a LEGENDA:

\section{LEGENDA:}

$$
1=0 \text { A } 10 \% \quad 2=11 \text { A } 30 \% \quad 3=31 \text { A } 50 \% \quad 4=51 \text { A } 70 \% \quad 5=71 \text { A } 90 \% \quad 6=91 \text { a } 100 \%
$$

\begin{tabular}{|l|c|c|}
\hline \multicolumn{1}{|c|}{ AÇÕES PERMANENTES: } & $\begin{array}{c}\% \\
\text { desejada }\end{array}$ & $\begin{array}{c}\% \\
\text { atingida }\end{array}$ \\
\hline \hline Refeições & & \\
\hline Transporte & & \\
\hline Previdência Privada & & \\
\hline Redução da Rotatividade & & \\
\hline Redução do absenteísmo & & \\
\hline Saúde e segurança & & \\
\hline Cesta Básica & & \\
\hline Gestão participativa & & \\
\hline Outra (identifique): & & \\
\hline
\end{tabular}

\begin{tabular}{|l|c|c|}
\hline \multicolumn{1}{|c|}{ AÇÕES TEMPORÁRIAS } & $\begin{array}{c}\% \\
\text { deseja } \\
\text { da }\end{array}$ & $\begin{array}{c}\% \\
\text { atingid } \\
\text { a }\end{array}$ \\
\hline \hline Melhorias no ambiente físico & & \\
\hline Melhoria nas ferramentas & & \\
\hline Campanha sobre AIDS & & \\
\hline Campanha sobre DROGAS & & \\
\hline Campanha sobre FUMO & & \\
\hline Controle da OBESIDADE & & \\
\hline Controle do Desperdício & & \\
\hline Novos benefícios & & \\
\hline Outra $_{\text {(identifique) }}$ & & \\
\hline
\end{tabular}

5.2 A empresa desenvolve outros Programas ou Ações de Qualidade Total?

Não ( )

Sim ( ) : Assinale com um $\mathrm{X}$ os programas existentes:

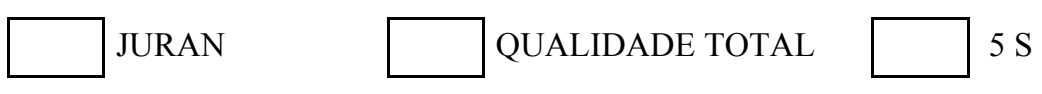




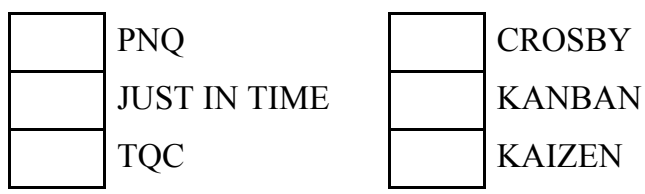

\begin{tabular}{|l|l}
\hline & CEP \\
\hline & COMITÊS DE QUALIDADE \\
\hline & OUTRO $_{\text {(identifique): }}$
\end{tabular}


5.3.Escreva no quadro abaixo o programa de melhoria da sua empresa que você considera mais importante para a Qualidade de Vida no Trabalho dos empregados da sua empresa?

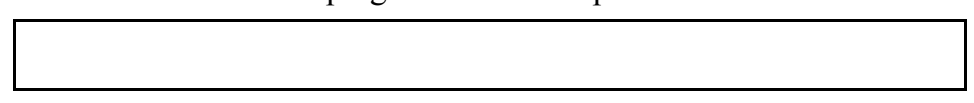

\section{BLOCO 6 - ESTRUTURA ORGANIZACIONAL DE QVT}

Este bloco pretende identificar as características organizacionais dos projetos, serviços e procedimentos de Qualidade de Vida no Trabalho, da sua empresa. Assinale com um $\mathbf{X}$ a resposta mais adequada e descreva as informações quando for $o$ caso.

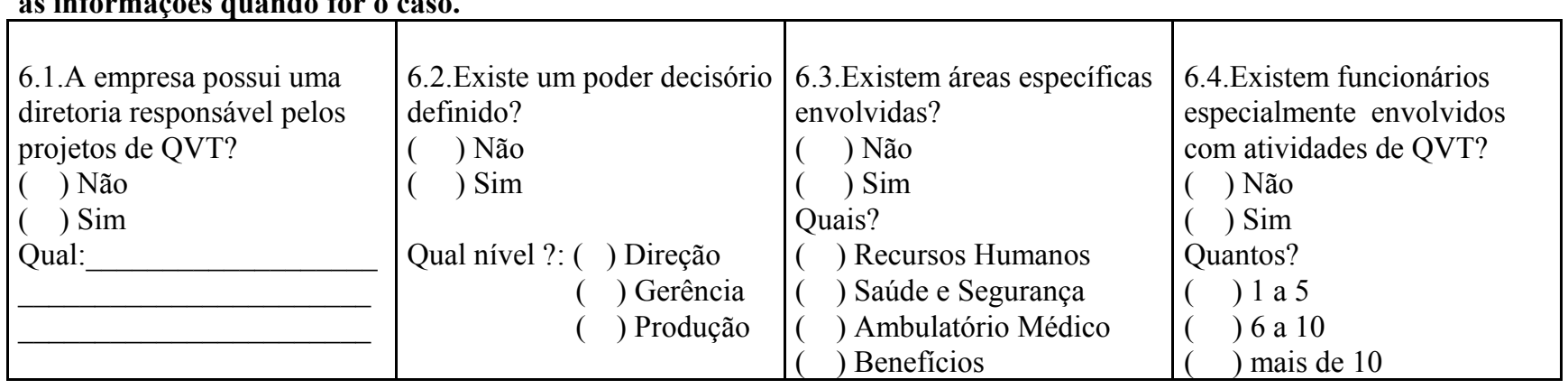

6.5.A sua empresa utiliza métodos específicos para levantar necessidades de QVT?

( ) Não

( ) Sim

Quais?

( ) número de acidentes

( ) ambulatório

( ) diagnóstico do clima

( ) determinação legal

( ) auditoria interna

( ) outra $_{\text {(identifique): }}$
6.6.É possível identificar o tempo de existência das atividades de QVT?

( ) Não

( ) $\mathrm{Sim}$

Existe há quanto tempo?

( ) até 1 ano

) 1 ano a 3 anos

) 3 anos a 5 anos

) mais de 5 anos
67.Existem propostas para novos programas nos próximos doze meses?

( ) Não

( ) $\mathrm{Sim}$

Quais? (identifique)

1.

2.

3

4.
6.8.É possível avaliar a duração das atividades?

( ) Não

( ) $\mathrm{Sim}$

Qual a duração total dos serviços ou projetos de QVT?

( ) dias

( ) semanas

( ) meses

( ) anos

( ) Outra(identifique):

\begin{tabular}{|c|c|c|c|}
\hline $\begin{array}{l}\text { 6.9.Há dotação orçamentária } \\
\text { pré-estabelecida? } \\
\text { ( ) Não } \\
\text { ( ) Sim } \\
\text { Valor: } \\
\text { ( )Mensal: R\$ } \\
\text { ( )Anual:R\$ } \\
\text { ( ) Outro } \\
\text { (especifique):R\$ }\end{array}$ & $\begin{array}{l}\text { 6.10.Há uma destinação } \\
\text { orçamentária específica? } \\
\text { ( } \quad \text { ) Não } \\
\text { ( } \quad \text { Sim } \\
\text { De que tipo? } \\
\text { ( } \quad) \text { Por departamento } \\
\text { ( } \quad) \text { Por projeto } \\
\text { ( } \quad) \text { Por usuário } \\
\text { ( } \quad) \text { Outra (identifique) }\end{array}$ & $\begin{array}{l}\text { 6.11.Existe uma porcen- } \\
\text { tagem calculada de inves- } \\
\text { timento com relação ao } \\
\text { faturamento anual? } \\
\text { ( ) Não } \\
\text { ( ) Sim } \\
\text { Qual a porcentagem? } \\
0,01 \text { a } 0,90 \% \\
1,00 \text { a } 1,50 \% \\
\text { Outra (identifique): }\end{array}$ & $\begin{array}{l}\text { 6.12.Existem atividades } \\
\text { formais denominadas Quali- } \\
\text { dade de Vida no Trabalho? } \\
\text { ( ) Não } \\
\text { ( ) Sim } \\
\text { Quais? } \\
\text { ( ) Campanhas } \\
\text { ( ) Palestras } \\
\text { ( ) Novos benefícios } \\
\text { ( ) No posto de trabalho } \\
\text { ( )Mudanças adminitrativas }\end{array}$ \\
\hline
\end{tabular}

6.13.Existe controle sistemático de resultados?

( )Não

( )Sim

De que forma:
6.14.Os programas e ações de QVT tem uma importância na certificação ISO 9000?

( )Não

( ) Sim
6.15.Os programas e ações de QVT tem valor para a política de negócios da empresa?

( ) Não ( ) Sim
6.16.Dados financeiros:

Lucro Líquido de 1995:

Patrimônio líquido: 


\begin{tabular}{|c|c|c|c|}
\hline $\begin{array}{l}\text { ( ) questionários } \\
\text { ( ) controle numérico } \\
\text { ( ) comitês de avaliação } \\
\text { ( ) Outro } \\
\text { (identifique) }\end{array}$ & Qual o motivo principal? & Qual o motivo principal? & Receita de 1995 \\
\hline
\end{tabular}


BLOCO 7 - DADOS GERAIS

\begin{tabular}{|c|c|c|c|}
\hline $\begin{array}{l}\text { Cargo } \\
\text { atual: }\end{array}$ & & Idade: & $\begin{array}{l}\text { Sexo:( )Fem. ( } \\
\text { )Masc }\end{array}$ \\
\hline $\begin{array}{l}\text { Nível hierárquico: } \\
\text { ( ) produção } \\
\text { ( ) supervisão } \\
\text { ( ) gerência } \\
\text { ( ) direção } \\
\text { É sindicalizado? } \\
\text { ( ) Sim () Não }\end{array}$ & 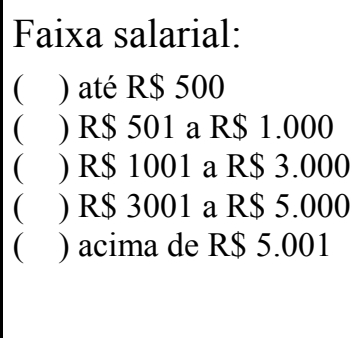 & $\begin{array}{l}\text { Escolaridade: } \\
\text { ( ) até 4a.série } \\
\text { ( ) até 8a.série } \\
\text { ( ) até segundo grau } \\
\text { ( ) faculdade incompleta } \\
\text { ( ) faculdade completa } \\
\text { ( ) Outra (identifique) }\end{array}$ & $\begin{array}{l}\text { Número de dependentes: } \\
(\text { ) nenhum } \\
(\text { ) }) \text { um } \\
(\text { ) dois } \\
(\text { ) três } \\
(\text { ) quatro } \\
(\text { ) cinco } \\
(\text { ) mais de cinco }\end{array}$ \\
\hline
\end{tabular}

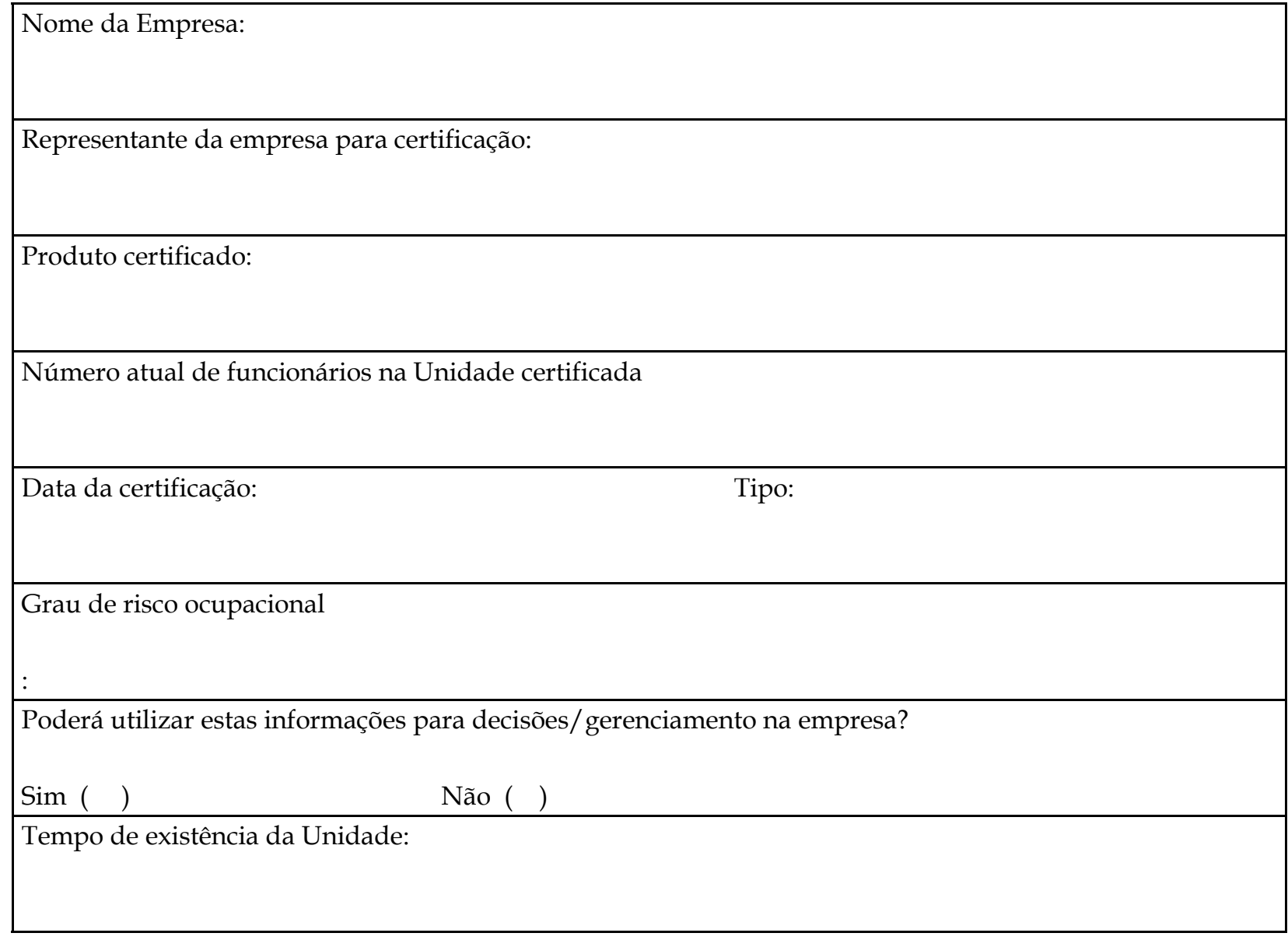

Como é a Qualidade de Vida da sua Empresa(quanto a organização, dimensões, objetivo e qualidade)? 
\begin{tabular}{|l|l|}
\hline \\
\hline
\end{tabular}

Comentários, Observações e Sugestões: 


\title{
ANEXO 2
}

\section{UNIVERSO DAS UNIDADES CERTIFICADAS - HISTÓRICO}

\author{
LEGENDA: \\ $\square=$ UNIDADES CERTIFICADAS SORTEADAS

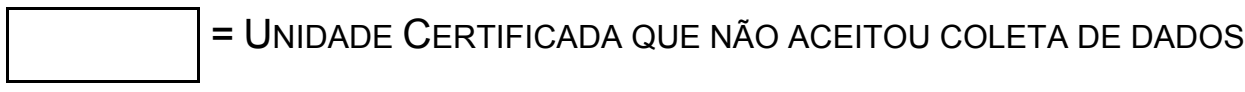

\begin{tabular}{|c|c|c|c|c|}
\hline Produto Certificado & $\begin{array}{l}\mathrm{N}^{\circ} \text { de } \\
\text { Func. }\end{array}$ & $\begin{array}{l}\text { Local da } \\
\text { Planta }\end{array}$ & Responsável & $\begin{array}{c}\text { Posição com relação à } \\
\text { pesquisa in "loco" }\end{array}$ \\
\hline Auto-peças & 270 & S.Caetano & $\begin{array}{l}\text { Sup. Administrativo- } \\
\text { Financeiro( gerência) }\end{array}$ & Pesquisada \\
\hline Equipamentos para plantas & 277 & Osasco & $\begin{array}{c}\text { Assessor da Diretoria } \\
\text { da Qualidade }\end{array}$ & Pesquisada \\
\hline $\begin{array}{l}\text { Micros e sistemas de grande } \\
\text { porte }\end{array}$ & 130 & SP & & \\
\hline Auto-peças & 191 & SBC & $\begin{array}{c}\text { Assessor da Diretoria } \\
\text { e Gerente de } \\
\text { Recursos Humanos }\end{array}$ & Não realizada \\
\hline Barras forjadas & 160 & S.Caetano & & \\
\hline Barras de aço & 242 & Diadema & $\begin{array}{c}\text { Diretor da } \\
\text { Fábrica/Gerente } \\
\text { Industrial }\end{array}$ & Pesquisada \\
\hline Placas de circuito de impressão & 186 & SP & $\begin{array}{c}\text { Gerente de Recursos } \\
\text { Humanos }\end{array}$ & Não realizada \\
\hline Produtos eletrônicos & 360 & SP & $\begin{array}{c}\text { Analista de Recursos } \\
\text { Humanos }\end{array}$ & Pesquisada \\
\hline Canaletas - caixas de luz & 263 & SBC & $\begin{array}{c}\text { Gerente de Recursos } \\
\text { Humanos }\end{array}$ & Pesquisada \\
\hline Aço laminado & 390 & SP & $\begin{array}{c}\text { Gerente de Recursos } \\
\text { Humanos }\end{array}$ & $\begin{array}{l}\text { Só gerência recursos } \\
\text { humanos }\end{array}$ \\
\hline Aço laminado & 307 & Sto André & & \\
\hline Sistemas de automação & 190 & SP & & \\
\hline $\begin{array}{l}\text { Microcomputadores e placas } \\
\text { acessórias }\end{array}$ & 180 & SP & $\begin{array}{c}\text { Gerente de Recursos } \\
\text { Humanos. }\end{array}$ & Não realizada \\
\hline $\begin{array}{l}\text { Equipamentos de } \\
\text { telecomunicações }\end{array}$ & 275 & SP & $\begin{array}{c}\text { Gerente de Recursos } \\
\text { Humanos }\end{array}$ & Não realizada \\
\hline Fabricação de pigmentos & 105 & SBC & $\begin{array}{c}\text { Gte de Desenv./Gte } \\
\text { de Qualidade }\end{array}$ & Pesquisada \\
\hline $\begin{array}{l}\text { Soluções peritonais e } \\
\text { intravenosas }\end{array}$ & 347 & SP & $\begin{array}{c}\text { Diretor de Recursos } \\
\text { Humanos }\end{array}$ & Pesquisada \\
\hline Embalagens e fibras de plástico & 331 & SP & & \\
\hline $\begin{array}{l}\text { Cabos de aço, cordoalhas, } \\
\text { arames }\end{array}$ & 376 & Osasco & $\begin{array}{c}\text { Gerente de Recursos } \\
\text { Humanos }\end{array}$ & Não realizada \\
\hline
\end{tabular}




\begin{tabular}{|c|c|c|c|c|}
\hline Produto Certificado & $\begin{array}{l}\mathrm{N}^{\circ} \text { de } \\
\text { Func. }\end{array}$ & $\begin{array}{l}\text { Local da } \\
\text { Planta }\end{array}$ & Responsável & $\begin{array}{c}\text { Posição com relação à } \\
\text { pesquisa in "loco" }\end{array}$ \\
\hline Cabos de aço & 313 & Osasco & $\begin{array}{c}\text { Gerente de Recursos } \\
\text { Humanos }\end{array}$ & Não realizada \\
\hline Válvulas & 250 & SP & & \\
\hline $\begin{array}{l}\text { Componentes e painéis de } \\
\text { controle }\end{array}$ & 179 & SP & $\begin{array}{c}\text { Gerente de Recursos } \\
\text { Humanos }\end{array}$ & Pesquisada \\
\hline $\begin{array}{l}\text { Equipamentos para indústria } \\
\text { Produtos sinretizados. }\end{array}$ & 326 & Sto André & & \\
\hline $\begin{array}{l}\text { Adesivos e massas, produtos } \\
\text { químicos }\end{array}$ & 150 & SP & $\begin{array}{c}\text { Gerente de Recursos } \\
\text { Humanos }\end{array}$ & $\begin{array}{l}\text { Pesquidada somente } \\
\text { gerência de recursos } \\
\text { humanos }\end{array}$ \\
\hline $\begin{array}{l}\text { Indústria metalúrgica peças } \\
\text { forjeadas }\end{array}$ & 400 & Osasco & & \\
\hline Produtos P.V.C & 100 & SP & & \\
\hline $\begin{array}{l}\text { Manômetros, pressostatos, } \\
\text { termômetros e outros. }\end{array}$ & 126 & S.Caetano & $\begin{array}{c}\text { Gerente de Recursos } \\
\text { Humanos }\end{array}$ & Pesquisada \\
\hline $\begin{array}{l}\text { Produtos de comunicação de } \\
\text { dados }\end{array}$ & 108 & SP & & \\
\hline Feixe de molas para automóveis & 438 & SBC & $\begin{array}{c}\text { Gerente de Recursos } \\
\text { humanos }\end{array}$ & Pesquisada \\
\hline Auto-peças & 400 & SP & $\begin{array}{c}\text { Diretor Administrativo } \\
\text { e de Pessoal }\end{array}$ & Pesquisada \\
\hline Fios texteis & 130 & Osasco & $\begin{array}{c}\text { Gerente de Recursos } \\
\text { Humanos }\end{array}$ & Pesquisada \\
\hline $\begin{array}{l}\text { Coberturas, pigmentos e materiais } \\
\text { cerâmicos }\end{array}$ & 231 & SBC & & \\
\hline Equipamentos de automação & 450 & SP & $\begin{array}{c}\text { Diretor Administrativo } \\
\text { e de Informática }\end{array}$ & Pesquisada \\
\hline $\begin{array}{l}\text { Indústria metalúrgica de } \\
\text { disjuntores }\end{array}$ & 134 & SP & $\begin{array}{c}\text { Gerente de Recursos } \\
\text { Humanos }\end{array}$ & Não realizada \\
\hline Produtos químicos & 102 & Diadema & & \\
\hline $\begin{array}{l}\text { Acessórios e instrumentos de } \\
\text { medição }\end{array}$ & 106 & Diadema & & \\
\hline Indústria de injeção de plástico & 300 & SP & $\begin{array}{l}\text { Analista de recursos } \\
\text { humanos }\end{array}$ & Não realizada \\
\hline Produtos da indústria mecânica & 180 & $\mathrm{SP}$ & $\begin{array}{c}\text { Gerente R.H. } \\
\text { Diretoria Industrial }\end{array}$ & Pesquisada \\
\hline Armação de carroceria e funilaria & 350 & SBC & $\begin{array}{c}\text { Gerente de Recursos } \\
\text { Humanos/ Gerente } \\
\text { da Qualidade }\end{array}$ & Não realizada \\
\hline Condutores elétrios: fios sólidos & 240 & SP & $\begin{array}{c}\text { Gerente de Recursos } \\
\text { Humanos }\end{array}$ & \begin{tabular}{|l|}
$\begin{array}{l}\text { Pesquisada só primeira } \\
\text { parte }\end{array}$ \\
\end{tabular} \\
\hline Componentes hidráulicos & 412 & Diadema & $\begin{array}{c}\text { Gerente de Recursos } \\
\text { Humanos }\end{array}$ & $\begin{array}{l}\text { Não realizada, com } \\
\text { carta justificando }\end{array}$ \\
\hline Placas de circuito & 330 & SP & $\begin{array}{c}\text { Gerente de Recursos } \\
\text { Humanos }\end{array}$ & Pesquisada \\
\hline Litárgio e pigmentos & 204 & Santo andré & Coordenadora de & Não realizada \\
\hline
\end{tabular}




\begin{tabular}{|l|l|l|l|l|}
\hline & & & Pessoal & \\
\hline $\begin{array}{l}\text { Produtos e serviços de } \\
\text { informática }\end{array}$ & 135 & SP & & \\
\hline
\end{tabular}

\begin{tabular}{|c|c|c|c|c|}
\hline Produto Certificado & $\begin{array}{l}\mathrm{N}^{\circ} \text { de } \\
\text { Func. }\end{array}$ & $\begin{array}{l}\text { Local da } \\
\text { Planta }\end{array}$ & Responsável & \begin{tabular}{|c|} 
Posição com relação à \\
pesquisa in "loco"
\end{tabular} \\
\hline $\begin{array}{l}\text { Sistemas de comunicação móveis } \\
\text { e celular }\end{array}$ & 188 & Guarulhos & & \\
\hline $\begin{array}{l}\text { Sistemas elétricos, carregadores } \\
\text { de baterias }\end{array}$ & 350 & $\mathrm{SP}$ & $\begin{array}{c}\text { Gerente da Qualidade } \\
\text { e Gerente de } \\
\text { Recursos Humanos }\end{array}$ & Não realizada \\
\hline Produção de ácidos & 250 & $\mathrm{SP}$ & $\begin{array}{l}\text { Responsável por } \\
\text { Recursos Humanos } \\
\text { (vide carta) }\end{array}$ & $\begin{array}{l}\text { Pesquisada só } \\
\text { gerência de recursos } \\
\text { humanos. }\end{array}$ \\
\hline Água oxigenada & 108 & Sto André & Gerente da Qualidade & Pesquisada \\
\hline Polietileno de baixa densidade - & 130 & Sto André & $\begin{array}{l}\text { Responsável por R. } \\
\text { H. e Responsável por } \\
\text { Treinamento }\end{array}$ & Pesquisada \\
\hline Terminais financeiros & 193 & $\mathrm{SP}$ & Supervisora R.H. & Não realizada \\
\hline Produtos indústria mecânica & 230 & $\mathrm{SP}$ & $\begin{array}{c}\text { Gerente de Recursos } \\
\text { Humanos }\end{array}$ & Não realizada \\
\hline Fios e cabos elétricos & 460 & $\mathrm{SP}$ & & \\
\hline Filter tow & 188 & Sto André & & \\
\hline Plásticos de engenharia & 250 & Sto André & & \\
\hline Impressoras & 160 & $\mathrm{SP}$ & & \\
\hline $\begin{array}{l}\text { Usina de faiscamento para fogão, } \\
\text { detetor de vibração }\end{array}$ & 193 & SP & & \\
\hline Brocas & 117 & SP & & \\
\hline $\begin{array}{l}\text { Pastilhas intercambiáveis de metal } \\
\text { duro }\end{array}$ & 230 & $\mathrm{SP}$ & $\begin{array}{c}\text { Gerente de } \\
\text { Benefícios (em } \\
\text { exercício direção de } \\
\text { Recursos Humanos) }\end{array}$ & Não realizadal \\
\hline Fabricação de válvulas & 220 & SP & $\begin{array}{c}\text { Gerente de Recursos } \\
\text { Humanos/Gerente da } \\
\text { Qualidade }\end{array}$ & Pesquisada \\
\hline Materiais eléletricos & 325 & $\mathrm{SP}$ & & \\
\hline $\begin{array}{l}\text { Chaves, selecionadores, } \\
\text { disjuntores }\end{array}$ & 133 & SP & $\begin{array}{c}\text { Gte Benefícios, } \\
\text { Coord. do Comitê de } \\
\text { Qualidade de Vida }\end{array}$ & Pesquisada \\
\hline $\begin{array}{l}\text { Equipamentos bebidas } \\
\text { gazeificadas }\end{array}$ & 200 & SP & $\begin{array}{c}\text { Vice-presidente de } \\
\text { Recursos } \\
\text { Humanos/Gerente } \\
\text { Industrial } \\
\end{array}$ & Pesquisada \\
\hline Indústria metalúrgica, ferramentas & 118 & SP & & \\
\hline
\end{tabular}




\begin{tabular}{|c|c|c|c|c|}
\hline Bombas e compressores & 397 & SBC & $\begin{array}{c}\text { Gerente de Recursos } \\
\text { Humanos/ Analista de } \\
\text { Recursos Humanos }\end{array}$ & Não realizada \\
\hline Fabricação de tintas & 350 & SP & $\begin{array}{c}\text { Gerente de Recursos } \\
\text { Humanos /Gte } \\
\text { Qualidade e Diretor } \\
\text { Industrial }\end{array}$ & $\begin{array}{l}\text { Pesquisada só } \\
\text { gerência } \\
\text { de recursos humanos }\end{array}$ \\
\hline
\end{tabular}

\begin{tabular}{|l|c|c|c|l|}
\hline \multicolumn{1}{|c|}{ Produto Certificado } & $\begin{array}{c}\mathrm{N}^{\circ} \text { de } \\
\text { Func. }\end{array}$ & $\begin{array}{c}\text { Local da } \\
\text { Planta }\end{array}$ & Responsável & $\begin{array}{c}\text { Posição com relação à } \\
\text { pesquisa in "loco" }\end{array}$ \\
\hline $\begin{array}{l}\text { Equipamentos de } \\
\text { telecomunicações e transmissão }\end{array}$ & 213 & SP & $\begin{array}{c}\text { Gerente de } \\
\text { R.H./Analista de } \\
\text { Recursos Humanos }\end{array}$ & Não realizada \\
\hline Motores, geradores e painéis & 280 & SP & $\begin{array}{c}\text { Gerente de Recursos } \\
\text { Humanos. }\end{array}$ & Pesquisada \\
\hline $\begin{array}{l}\text { UNISYS - produtos ozonados - } \\
\text { indústria química }\end{array}$ & 150 & SP & & \\
\hline $\begin{array}{l}\text { Consumíveis de solda, eletrodos, } \\
\text { varetas, arames }\end{array}$ & 144 & SP & & \\
\hline Tambores de aço & 229 & SP & & \\
\hline Bombas centrífugas & 140 & SP & & \\
\hline
\end{tabular}




\section{ANEXO 3}

\section{DADOS DAS VARIÁVEIS DA UNIDADE CERTIFICADA}

Tabela 3.1 Indicadores de ênfase organizacional

\begin{tabular}{|c|c|c|c|c|c|c|c|}
\hline EMPRESA & IMAGEM & $\begin{array}{c}\text { DESENV. } \\
\text { TREINAM. }\end{array}$ & $\begin{array}{c}\text { PROCES. } \\
\text { TECNOL. }\end{array}$ & COMITÊS & $\begin{array}{c}\text { BURO- } \\
\text { CRACIA }\end{array}$ & $\begin{array}{c}\text { ROTINAS } \\
\text { DE } \\
\text { PESSOAL }\end{array}$ & MÉDIA \\
\hline 1 & 7,75 & 7,15 & 6,90 & 5,90 & 6,89 & 8,20 & 7,13 \\
\hline 2 & 7,50 & 6,70 & 6,00 & 6,90 & 5,60 & 8,85 & 6,92 \\
\hline 3 & 6,95 & 5,80 & 5,95 & 5,35 & 4,85 & 7,95 & 6,14 \\
\hline 4 & 8,00 & 7,25 & 6,35 & 5,35 & 6,37 & 8,47 & 6,98 \\
\hline 5 & 4,90 & 3,30 & 2,85 & 1,20 & 3,45 & 8,30 & 4,00 \\
\hline 6 & 8,10 & 7,40 & 7,30 & 6,10 & 6,45 & 8,45 & 7,30 \\
\hline 7 & 5,45 & 4,20 & 5,65 & 3,15 & 4,95 & 8,70 & 5,35 \\
\hline 9 & 6,70 & 6,30 & 7,95 & 4,90 & 6,25 & 8,70 & 6,80 \\
\hline 11 & 7,30 & 5,85 & 7,05 & 5,20 & 6,55 & 8,30 & 6,71 \\
\hline 12 & 6,85 & 6,70 & 6,80 & 5,25 & 5,80 & 8,85 & 6,71 \\
\hline 13 & 7,60 & 7,95 & 8,25 & 6,65 & 6,65 & 9,05 & 7,69 \\
\hline 10 & 6,95 & 6,45 & 5,70 & 5,25 & 6,25 & 8,05 & 6,44 \\
\hline 14 & 4,70 & 5,15 & 5,10 & 4,30 & 4,45 & 5,75 & 4,91 \\
\hline 20 & 6,10 & 4,95 & 5,80 & 4,05 & 4,85 & 7,55 & 5,55 \\
\hline 16 & 7,75 & 7,95 & 8,25 & 7,60 & 7,68 & 8,58 & 7,98 \\
\hline 18 & 6,90 & 6,70 & 7,30 & 5,15 & 6,50 & 8,85 & 6,90 \\
\hline 19 & 7,75 & 8,70 & 7,95 & 7,15 & 7,25 & 8,75 & 7,93 \\
\hline 21 & 8,80 & 8,15 & 7,90 & 6,60 & 5,75 & 8,75 & 7,66 \\
\hline 22 & 6,90 & 6,55 & 6,00 & 5,16 & 5,35 & 7,70 & 6,28 \\
\hline 24 & 6,60 & 6,30 & 6,05 & 5,00 & 5,30 & 8,75 & 6,33 \\
\hline 25 & 8,40 & 8,15 & 8,00 & 6,20 & 7,15 & 8,74 & 7,75 \\
\hline
\end{tabular}




\section{DADOS DAS VARIÁVEIS DA UNIDADE CERTIFICADA}

Tabela 3.2 Indicadores de ênfase biológica

\begin{tabular}{|c|c|c|c|c|c|c|c|c|c|}
\hline EMPRESA & SIPAT & PPRA & $\begin{array}{c}\text { AMBULA- } \\
\text { TÓRIO }\end{array}$ & $\begin{array}{c}\text { CONVÊ } \\
\text { NIO }\end{array}$ & $\begin{array}{c}\text { GINÁS- } \\
\text { TICA }\end{array}$ & $\begin{array}{c}\text { REFEI- } \\
\text { ÇÕES }\end{array}$ & PCSMO & CIPA & MÉDIA \\
\hline 1 & 6,25 & 5,95 & 1,70 & 6,39 & 2,95 & 8,00 & 7,47 & 5,40 & 5,52 \\
\hline 2 & 8,40 & 7,50 & 8,15 & 8,50 & 7,25 & 8,40 & 7,80 & 6,85 & 7,86 \\
\hline 3 & 4,95 & 6,30 & 4,90 & 6,60 & 0,90 & 6,85 & 7,15 & 5,35 & 5,37 \\
\hline 4 & 7,40 & 7,71 & 3,80 & 0,75 & 1,58 & 6,60 & 7,05 & 8,26 & 5,36 \\
\hline 5 & 7,47 & 5,68 & 4,45 & 6,90 & 0,58 & 5,90 & 5,20 & 4,65 & 5,17 \\
\hline 6 & 8,10 & 7,80 & 7,80 & 8,40 & 2,10 & 7,25 & 7,35 & 7,55 & 7,04 \\
\hline 7 & 3,40 & 3,70 & 2,20 & 7,75 & 0,35 & 1,10 & 7,50 & 4,15 & 3,77 \\
\hline 9 & 7,60 & 7,05 & 6,05 & 9,16 & 1,30 & 6,05 & 7,58 & 7,55 & 6,54 \\
\hline 11 & 7,90 & 6,85 & 8,55 & 6,79 & 2,15 & 5,40 & 7,55 & 6,40 & 6,44 \\
\hline 12 & 5,40 & 5,35 & 7,00 & 8,00 & 1,95 & 6,26 & 6,40 & 4,25 & 5,57 \\
\hline 13 & 8,50 & 7,95 & 9,42 & 8,50 & 2,40 & 7,45 & 7,80 & 7,80 & 7,47 \\
\hline 10 & 6,40 & 5,65 & 8,15 & 7,35 & 2,10 & 6,50 & 7,20 & 5,70 & 6,13 \\
\hline 14 & 2,70 & 3,30 & 1,95 & 3,05 & 0,85 & 1,00 & 6,80 & 3,35 & 2,87 \\
\hline 20 & 3,60 & 5,55 & 4,25 & 7,40 & 1,45 & 3,60 & 7,45 & 4,95 & 4,78 \\
\hline 16 & 7,45 & 7,67 & 8,47 & 7,33 & 1,35 & 6,44 & 8,40 & 6,70 & 6,71 \\
\hline 18 & 7,35 & 7,10 & 8,15 & 8,05 & 3,45 & 6,15 & 7,45 & 5,70 & 6,67 \\
\hline 19 & 7,40 & 8,20 & 8,05 & 8,35 & 2,75 & 7,60 & 7,90 & 7,70 & 2,24 \\
\hline 21 & 8,05 & 8,10 & 8,35 & 8,75 & 5,55 & 7,45 & 8,35 & 7,45 & 7,76 \\
\hline 22 & 6,15 & 6,89 & 8,60 & 7,95 & 9,20 & 8,95 & 7,72 & 6,35 & 7,71 \\
\hline 24 & 7,40 & 6,05 & 7,55 & 7,65 & 2,30 & 7,35 & 7,45 & 6,10 & 6,48 \\
\hline 25 & 8,45 & 8,00 & 8,90 & 8,85 & 2,35 & 7,35 & 7,40 & 7,45 & 7,34 \\
\hline
\end{tabular}




\section{DADOS DAS VARIÁVEIS DA UNIDADE CERTIFICADA}

Tabela 3.3 Indicadores de ênfase psicológica

\begin{tabular}{|c|c|c|c|c|c|c|c|}
\hline EMPRESA & $\begin{array}{c}\text { RECRUT. } \\
\text { SELEÇÃO }\end{array}$ & $\begin{array}{c}\text { AVALIAÇÃO } \\
\text { DESEMP. }\end{array}$ & $\begin{array}{c}\text { CLIMA } \\
\text { ORGANIZ. }\end{array}$ & CARREIRA & SALÁRIOS & $\begin{array}{c}\text { VIDA } \\
\text { PESSOAL }\end{array}$ & MÉDIA \\
\hline 1 & 6,47 & 6,65 & 8,05 & 6,30 & 5,85 & 5,05 & 6,42 \\
\hline 2 & 6,75 & 7,65 & 7,85 & 6,53 & 6,45 & 6,50 & 6,98 \\
\hline 3 & 7,15 & 5,50 & 6,45 & 5,15 & 6,20 & 7,15 & 6,27 \\
\hline 4 & 7,21 & 7,40 & 6,50 & 5,40 & 5,21 & 6,80 & 6,42 \\
\hline 5 & 4,75 & 3,85 & 6,95 & 1,95 & 3,10 & 5,11 & 4,38 \\
\hline 6 & 8,00 & 8,21 & 7,05 & 6,89 & 5,89 & 7,21 & 7,20 \\
\hline 7 & 6,20 & 4,20 & 7,80 & 3,10 & 4,65 & 6,50 & 5,41 \\
\hline 9 & 6,75 & 5,16 & 7,40 & 4,65 & 4,35 & 5,53 & 5,63 \\
\hline 11 & 6,20 & 7,20 & 7,25 & 3,95 & 6,45 & 6,20 & 6,21 \\
\hline 12 & 7,40 & 7,15 & 6,95 & 5,65 & 5,20 & 6,37 & 6,46 \\
\hline 13 & 7,25 & 6,95 & 7,25 & 6,35 & 5,95 & 6,95 & 6,77 \\
\hline 10 & 7,35 & 5,40 & 7,65 & 6,25 & 5,35 & 5,50 & 6,25 \\
\hline 14 & 5,11 & 5,05 & 7,20 & 3,80 & 4,95 & 4,89 & 5,10 \\
\hline 20 & 6,40 & 6,20 & 8,00 & 5,60 & 4,15 & 6,25 & 6,10 \\
\hline 16 & 7,40 & 6,85 & 7,40 & 6,16 & 5,65 & 5,94 & 6,60 \\
\hline 18 & 6,70 & 5,55 & 7,25 & 6,55 & 6,35 & 6,95 & 6,57 \\
\hline 19 & 8,15 & 8,50 & 7,95 & 7,60 & 6,70 & 6,75 & 7,61 \\
\hline 21 & 7,40 & 8,20 & 8,15 & 6,30 & 6,40 & 7,75 & 7,37 \\
\hline 22 & 6,95 & 7,05 & 7,65 & 6,85 & 5,05 & 5,95 & 6,59 \\
\hline 24 & 6,70 & 6,35 & 7,95 & 4,95 & 4,20 & 5,20 & 5,89 \\
\hline 25 & 7,70 & 8,00 & 9,10 & 6,20 & 7,05 & 7,60 & 7,61 \\
\hline
\end{tabular}




\section{DADOS DAS VARIÁVEIS DA UNIDADE CERTIFICADA}

Tabela 3.4 Indicadores de ênfase social

\begin{tabular}{|c|c|c|c|c|c|c|c|}
\hline EMPRESA & $\begin{array}{c}\text { CONVÉ- } \\
\text { NIOS }\end{array}$ & $\begin{array}{c}\text { TEMPO } \\
\text { LIVRE }\end{array}$ & FILHOS & $\begin{array}{c}\text { CESTA } \\
\text { BÁSICA }\end{array}$ & $\begin{array}{c}\text { PREVID. } \\
\text { PRIVADA }\end{array}$ & $\begin{array}{c}\text { FINANC. } \\
\text { EDUCAÇÃO }\end{array}$ & MÉDIA \\
\hline 1 & 7,85 & 7,11 & 1,85 & 6,50 & 4,33 & 3,68 & 5,25 \\
\hline 2 & 7,85 & 7,65 & 7,55 & 1,11 & 3,29 & 2,70 & 5,14 \\
\hline 3 & 7,05 & 1,37 & 2,16 & 5,95 & 6,75 & 5,65 & 4,86 \\
\hline 4 & 1,05 & 6,95 & 0,80 & 0,30 & 1,50 & 4,75 & 2,56 \\
\hline 5 & 4,50 & 3,60 & 1,16 & 0,70 & 1,45 & 0,05 & 2,05 \\
\hline 6 & 7,45 & 5,90 & 4,80 & 8,15 & 7,80 & 5,65 & 6,62 \\
\hline 7 & 1,10 & 0,85 & 0,30 & 0,55 & 2,35 & 0,55 & 0,95 \\
\hline 9 & 5,65 & 2,45 & 2,35 & 4,15 & 5,68 & 4,55 & 4,11 \\
\hline 11 & 6,45 & 4,85 & 2,65 & 1,20 & 5,80 & 2,25 & 3,87 \\
\hline 12 & 5,95 & 3,00 & 0,70 & 0,65 & 3,00 & 1,65 & 2,47 \\
\hline 13 & 7,10 & 5,25 & 3,05 & 3,70 & 5,65 & 5,90 & 5,13 \\
\hline 10 & 6,80 & 3,55 & 0,65 & 0,25 & 3,45 & 1,35 & 2,68 \\
\hline 14 & 0,80 & 0,85 & 0,00 & 0,00 & 0,45 & 0,35 & 0,41 \\
\hline 20 & 6,80 & 5,00 & 0,35 & 5,40 & 2,25 & 0,40 & $3,3,7$ \\
\hline 16 & 6,45 & 1,85 & 1,35 & 6,55 & 5,20 & 3,11 & 4,13 \\
\hline 18 & 8,15 & 6,50 & 5,32 & 0,00 & 5,95 & 6,74 & 5,53 \\
\hline 19 & 4,50 & 3,95 & 1,50 & 0,95 & 6,90 & 7,25 & 4,17 \\
\hline 21 & 7,15 & 7,55 & 5,20 & 8,35 & 8,20 & 6,55 & 7,17 \\
\hline 22 & 7,70 & 4,35 & 5,63 & 2,12 & 5,68 & 4,06 & 4,98 \\
\hline 24 & 6,50 & 5,05 & 1,25 & 0,40 & 3,25 & 1,95 & 3,07 \\
\hline 25 & 8,95 & 6,85 & 2,21 & 0,35 & 7,10 & 2,42 & 4,70 \\
\hline
\end{tabular}




\section{DADOS DAS VARIÁVEIS DA UNIDADE CERTIFICADA}

Tabela 3.5 Indicadores de autopercepção (da QVT).

\begin{tabular}{|c|c|c|c|c|c|c|}
\hline EMPRESA & $\begin{array}{c}\text { BEM- } \\
\text { ESTAR }\end{array}$ & TENSÃO & $\begin{array}{c}\text { QUALIDADE } \\
\text { DE VIDA }\end{array}$ & $\begin{array}{c}\text { QVT DA } \\
\text { EMPRESA }\end{array}$ & RESULTADO & MÉDIA \\
\hline 1 & 7,65 & 5,75 & 7,30 & 6,10 & 7,95 & 6,96 \\
\hline 2 & 7,05 & 5,80 & 6,65 & 6,40 & 7,79 & 6,74 \\
\hline 3 & 6,15 & 4,25 & 6,20 & 5,40 & 7,50 & 5,90 \\
\hline 4 & 8,10 & 6,95 & 7,55 & 5,15 & 6,95 & 6,94 \\
\hline 5 & 5,85 & 6,25 & 6,25 & 2,89 & 8,47 & 6,02 \\
\hline 6 & 8,20 & 6,95 & 7,55 & 7,55 & 8,20 & 7,69 \\
\hline 7 & 6,35 & 4,90 & 5,90 & 4,15 & 7,00 & 5,66 \\
\hline 9 & 7,05 & 4,55 & 5,80 & 5,65 & 7,75 & 6,16 \\
\hline 11 & 7,35 & 5,90 & 7,55 & 6,75 & 7,40 & 6,99 \\
\hline 12 & 6,75 & 6,60 & 6,35 & 5,80 & 7,95 & 6,69 \\
\hline 13 & 7,55 & 6,25 & 6,80 & 6,60 & 8,15 & 7,07 \\
\hline 10 & 6,80 & 6,00 & 7,10 & 5,95 & 7,65 & 6,70 \\
\hline 14 & 6,45 & 5,35 & 7,25 & 3,50 & 8,00 & 6,11 \\
\hline 20 & 6,85 & 6,00 & 6,30 & 4,85 & 7,30 & 6,26 \\
\hline 16 & 7,60 & 5,70 & 7,00 & 6,30 & 7,75 & 6,87 \\
\hline 18 & 7,55 & 6,25 & 7,40 & 6,85 & 8,90 & 7,39 \\
\hline 19 & 7,45 & 6,70 & 7,35 & 6,80 & 9,05 & 7,47 \\
\hline 21 & 8,45 & 7,50 & 7,55 & 8,05 & 8,90 & 8,09 \\
\hline 22 & 7,80 & 6,90 & 7,85 & 7,20 & 8,21 & 7,58 \\
\hline 24 & 7,25 & 5,60 & 5,90 & 4,80 & 6,85 & 6,08 \\
\hline 25 & 9,05 & 7,75 & 7,50 & 7,45 & 9,35 & 8,22 \\
\hline
\end{tabular}




\section{DADOS DAS VARIÁVEIS DA UNIDADE CERTIFICADA}

Tabela 3.6 Eventos clínicos dos empregados

\begin{tabular}{|c|c|c|c|c|c|c|}
\hline EMPRESA & REMÉDIOS & HOSPITAL & $\begin{array}{l}\text { PRONTO- } \\
\text { SOCORRO }\end{array}$ & CONVÊNIO & $\begin{array}{l}\text { AMBULATÓ- } \\
\text { RIO }\end{array}$ & FALTAS \\
\hline 1 & 5 & 0 & 4 & 13 & 8 & 8 \\
\hline 2 & 11 & 5 & 5 & 17 & 17 & 7 \\
\hline 3 & 9 & 0 & 6 & 13 & 11 & 7 \\
\hline 4 & 16 & 0 & 6 & 5 & 2 & 8 \\
\hline 5 & 6 & 2 & 2 & 12 & 6 & 2 \\
\hline 6 & 5 & 3 & 6 & 13 & 11 & 5 \\
\hline 7 & 10 & 0 & 6 & 16 & 5 & 9 \\
\hline 9 & 15 & 0 & 4 & 18 & 14 & 8 \\
\hline 11 & 11 & 2 & 0 & 13 & 13 & 3 \\
\hline 12 & 9 & 1 & 6 & 18 & 11 & 9 \\
\hline 13 & 10 & 1 & 3 & 10 & 7 & 2 \\
\hline 10 & 7 & 0 & 6 & 14 & 14 & 7 \\
\hline 14 & 7 & 0 & 1 & 8 & 1 & 6 \\
\hline 20 & 7 & 1 & 4 & 17 & 10 & 12 \\
\hline 16 & 7 & 1 & 6 & 18 & 13 & 7 \\
\hline 18 & 8 & 3 & 1 & 15 & 11 & 5 \\
\hline 19 & 12 & 0 & 1 & 15 & 10 & 3 \\
\hline 21 & 11 & 5 & 7 & 17 & 18 & 10 \\
\hline 22 & 9 & 5 & 5 & 17 & 13 & 9 \\
\hline 24 & 5 & 0 & 0 & 9 & 11 & 3 \\
\hline 25 & 14 & 5 & 5 & 18 & 19 & 8 \\
\hline
\end{tabular}




\section{ANEXO 4}

\section{FÓRMULAS E MATRIZES ESTATÍSTICAS}

\subsection{Expressão para composição da amostra dos empregados}

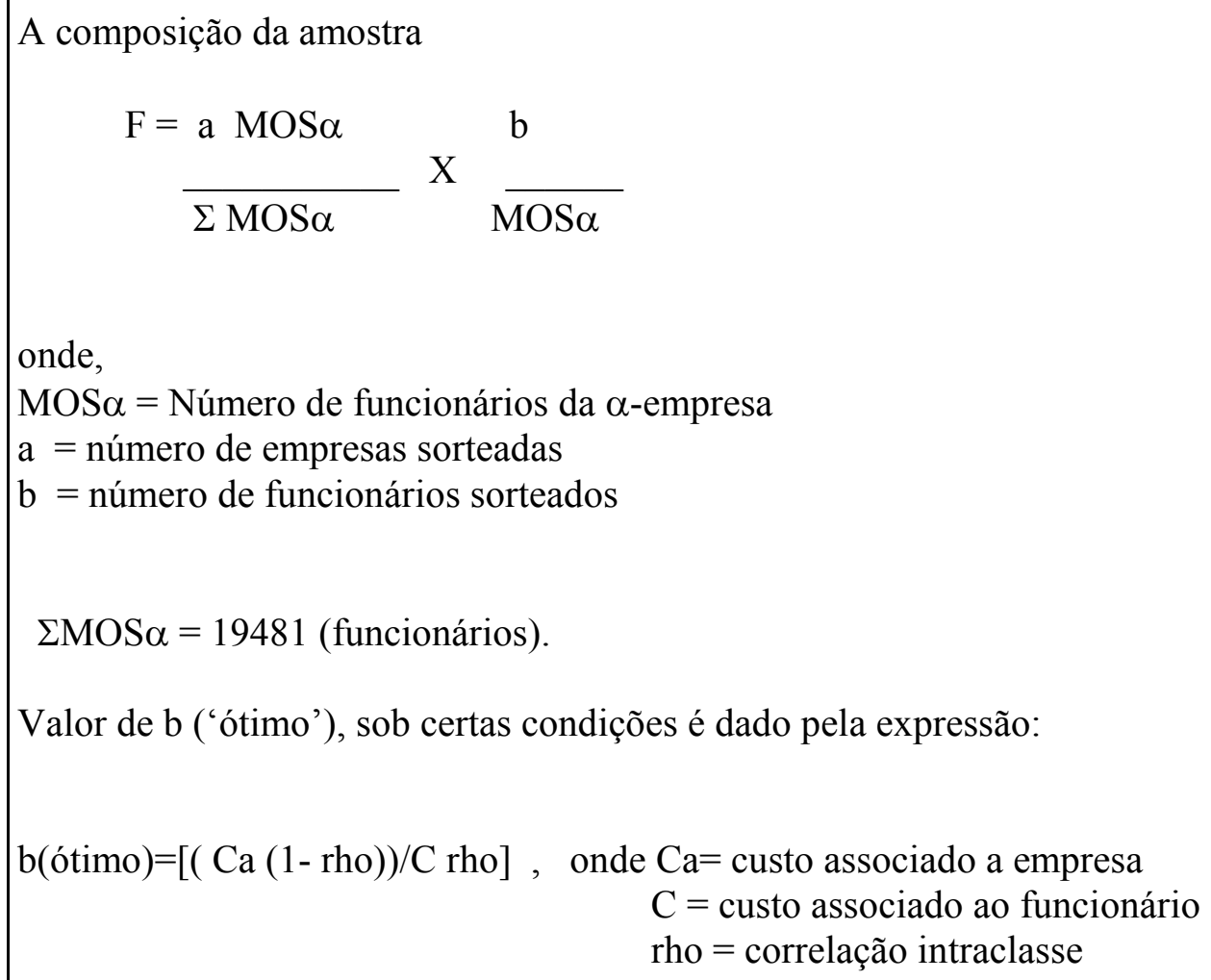

Opções para o valor de b:

\begin{tabular}{|c|c|c|c|}
\hline rho $\backslash(\mathrm{Ca} / \mathrm{C})$ & 10 & 20 & 30 \\
\hline 0.10 & 9 & 13 & 16 \\
\hline 0.05 & 14 & 19 & 24 \\
\hline 0.02 & 22 & 31 & 38 \\
\hline
\end{tabular}


4.2 Resultados dos fatores da matriz não rotacionada (análise fatorial) 4.2.1 Empregados

\begin{tabular}{|c|c|c|}
\hline Fator & $\begin{array}{c}\text { Proporção } \\
\text { (autovalor) }\end{array}$ & Acumulada \\
\hline 1 & 8.2302 & 0.3919 \\
2 & 1.6682 & 0.4714 \\
3 & 1.2346 & 0.5301 \\
4 & 1.0126 & 0.5784 \\
5 & 0.9573 & 0.6240 \\
6 & 0.8478 & 0.6643 \\
7 & 0.7956 & 0.7022 \\
8 & 0.6977 & 0.7354 \\
9 & 0.6446 & 0.7661 \\
10 & 0.6017 & 0.7948 \\
11 & 0.5757 & 0.8222 \\
12 & 0.5449 & 0.8481 \\
13 & 0.5174 & 0.8728 \\
14 & 0.4321 & 0.8934 \\
15 & 0.3892 & 0.9119 \\
16 & 0.3841 & 0.9302 \\
17 & 0.3486 & 0.9468 \\
18 & 0.3236 & 0.9622 \\
19 & 0.2939 & 0.9762 \\
20 & 0.2714 & 0.9891 \\
21 & 0.2287 & 1.0000 \\
\hline
\end{tabular}


4.2 Resultados dos fatores da matriz não rotacionada (análise fatorial)

4.2.1 Gerência de recursos humanos

\begin{tabular}{|c|c|c|}
\hline Fator & Auto-valor & $\begin{array}{c}\text { Proporção } \\
\text { Acumulada }\end{array}$ \\
\hline 1 & 7.6480 & 0.3642 \\
2 & 3.0787 & 0.5108 \\
3 & 1.6699 & 0.5903 \\
4 & 1.4405 & 0.6589 \\
5 & 1.3132 & 0.7214 \\
6 & 1.1520 & 0.7763 \\
7 & 1.0103 & 0.8244 \\
8 & 0.7962 & 0.8623 \\
9 & 0.6958 & 0.8955 \\
10 & 0.4994 & 0.9192 \\
11 & 0.4203 & 0.9392 \\
12 & 0.3012 & 0.9536 \\
13 & 0.2645 & 0.9662 \\
14 & 0.1813 & 0.9748 \\
15 & 0.1411 & 0.9815 \\
16 & 0.1388 & 0.9882 \\
17 & 0.0864 & 0.9923 \\
18 & 0.0713 & 0.9957 \\
19 & 0.0414 & 0.9976 \\
20 & 0.0283 & 0.9990 \\
21 & 0.0214 & 1.0000 \\
\hline
\end{tabular}




\subsection{Composição dos fatores}

\subsubsection{Empregados}

Fator 1: Atuação Organizacional (39\%)

\begin{tabular}{|l|l|l|l|c|c|c|c|}
\hline \multicolumn{1}{|c|}{ Variável } & $\begin{array}{c}\text { Comu- } \\
\text { nalidade }\end{array}$ & $\begin{array}{c}\text { Carga } \\
\text { Fatorial }\end{array}$ & $\begin{array}{c}0-3 \\
\%\end{array}$ & $\begin{array}{c}4-6 \\
\%\end{array}$ & $\begin{array}{c}7-10 \\
\%\end{array}$ & $\begin{array}{c}\text { Total } \\
\text { da \% }\end{array}$ & $\begin{array}{c}\text { Média- } \\
\text { X }\end{array}$ \\
\hline EM112 T\&D & 0.74 & 0.82 & 14 & 26 & 60 & 100 & 6,6 \\
\hline EM113 Processos e tecnologias & 0.68 & 0.80 & 11 & 29 & 60 & 100 & 6,6 \\
\hline EM114 Comitês de decisão & 0.62 & 0.74 & 25 & 34 & 41 & 100 & 6,4 \\
\hline EM115 Ausência de burocracia & 0.51 & 0.63 & 16 & 38 & 46 & 100 & 6 \\
\hline EM134 Carreira & 0.60 & 0.61 & 27 & 30 & 43 & 100 & 5,5 \\
\hline EM111 Imagem & 0.60 & 0.60 & 8 & 26 & 67 & 100 & 6,5 \\
\hline EM132 Avaliação do desempenho. & 0.4432 & 0.448 & 16 & 24 & 60 & 100 & 6,5 \\
\hline
\end{tabular}

Fator 2: Necessidades Biológicas (8\%)

\begin{tabular}{|l|l|l|l|l|l|l|l|}
\hline \multicolumn{1}{|c|}{ Variável } & $\begin{array}{c}\text { Comu- } \\
\text { nalidade }\end{array}$ & $\begin{array}{c}\text { Carga } \\
\text { Fatorial }\end{array}$ & $\begin{array}{c}0-3 \\
\%\end{array}$ & $\begin{array}{c}4-6 \\
\%\end{array}$ & $\begin{array}{c}7-10 \\
\%\end{array}$ & $\begin{array}{c}\text { Total } \\
\text { da } \%\end{array}$ & $\begin{array}{c}\text { Média } \\
\text { X }\end{array}$ \\
\hline EM121 SIPATS & 0,77 & 0.85 & 16 & 21 & 63 & 100 & 6.7 \\
\hline EM122 Riscos PPRA & 0.66 & 0.72 & 13 & 28 & 59 & 100 & 6.6 \\
\hline EM128 CIPA & 0.70 & 0.71 & 18 & 29 & 53 & 100 & 6.2 \\
\hline EM126 Refeições & 0.55 & 0.59 & 19 & 24 & 57 & 100 & 6.3 \\
\hline EM142 Tempo livre/lazer & 0.32 & 0.38 & 39 & 27 & 34 & 100 & 4.5 \\
\hline
\end{tabular}




\subsection{Composição dos fatores}

\subsubsection{Empregados (continuação)}

Fator 3: Inclusão Social (6\%)

\begin{tabular}{|l|c|c|c|c|c|c|c|}
\hline \multicolumn{1}{|c|}{ Variáveis } & $\begin{array}{c}\text { Comuna- } \\
\text { lidade }\end{array}$ & $\begin{array}{c}\text { Carga } \\
\text { Fatorial }\end{array}$ & $\begin{array}{c}0-3 \\
\%\end{array}$ & $\begin{array}{c}4-6 \\
\%\end{array}$ & $\begin{array}{c}7-10 \\
\%\end{array}$ & $\begin{array}{c}\text { Total } \\
\text { da \% }\end{array}$ & $\begin{array}{c}\text { Média } \\
\text { X }\end{array}$ \\
\hline EM136 Vida pessoal & 0.53 & 0.7103 & 16 & 35 & 49 & 100 & 6.3 \\
\hline EM133 Camaradagem/clima & 0.50 & 0.6747 & 8 & 18 & 74 & 100 & 7.5 \\
\hline EM131 Recrutamento e seleção & 0.52 & 0.5777 & 10 & 29 & 61 & 100 & 6.9 \\
\hline EM135 Salário & 0.5349 & 0.5251 & 26 & 32 & 42 & 100 & 5.5 \\
\hline EM127 Saúde - PCSMO & 0.4729 & 0.4964 & 6 & 20 & 74 & 100 & 7.4 \\
\hline EM142 Tempo livre/lazer & 0.3372 & 0.4564 & 5 & 9 & 86 & 100 & 8.4 \\
\hline
\end{tabular}

Fator 4: Prestação de Serviços (5\%)

\begin{tabular}{|l|c|c|c|c|c|c|c|}
\hline \multicolumn{1}{|c|}{ Variáveis } & $\begin{array}{c}\text { Comuna- } \\
\text { lidade }\end{array}$ & $\begin{array}{c}\text { Carga } \\
\text { Fatorial }\end{array}$ & $\begin{array}{c}0-3 \\
\%\end{array}$ & $\begin{array}{c}4-6 \\
\%\end{array}$ & $\begin{array}{c}7-10 \\
\%\end{array}$ & $\begin{array}{c}\text { Total da } \\
\%\end{array}$ & $\begin{array}{c}\text { Média } \\
\text { X }\end{array}$ \\
\hline EM124 Convênio médico & 0.74 & 0.84 & 13 & 17 & 71 & 100 & 7.3 \\
\hline EM141Convênios comerciais & 0.73 & 0.76 & 22 & 23 & 55 & 100 & 6,0 \\
\hline EM123 Ambulatório & 0.60 & 0.52 & 20 & 18 & 62 & 100 & 6.5 \\
\hline
\end{tabular}




\subsection{Composição dos fatores}

\subsubsection{Gerência de recursos humanos}

Fator 1: Imagem da Empresa (3\%)

\begin{tabular}{|l|c|c|c|c|c|c|c|}
\hline \multicolumn{1}{|c|}{ Variável } & $\begin{array}{c}\text { Comu- } \\
\text { nalidade }\end{array}$ & $\begin{array}{c}\text { Carga } \\
\text { Fatorial }\end{array}$ & $\begin{array}{c}0-3 \\
\%\end{array}$ & $\begin{array}{c}4-6 \\
\%\end{array}$ & $\begin{array}{c}7-10 \\
\%\end{array}$ & $\begin{array}{c}\text { Total } \\
\text { da } \%\end{array}$ & $\begin{array}{c}\text { Média } \\
\text { X }\end{array}$ \\
\hline EM115 Ausência de burocracia & 0.86 & 0.84 & 15 & 35 & 50 & 100 & 6.0 \\
\hline EM111 Imagem & 0.86 & 0.84 & 19 & 31 & 50 & 100 & 6.0 \\
\hline EM116 Rotinas de pessoal & 0.67 & 0.72 & 0 & 23 & 77 & 100 & 7.9 \\
\hline EM128 CIPA & 0.67 & 0.61 & 4 & 8 & 88 & 100 & 8.1 \\
\hline EM122 Riscos PPRA & 0.80 & 0.57 & 8 & 15 & 77 & 100 & 7.7 \\
\hline
\end{tabular}

Fator 2: Saúde e Ética

\begin{tabular}{|l|c|c|c|c|c|c|c|}
\hline \multicolumn{1}{|c|}{ Variável } & $\begin{array}{c}\text { Comunali } \\
\text {-dade }\end{array}$ & $\begin{array}{c}\text { Carga } \\
\text { Fatorial }\end{array}$ & $\begin{array}{c}0-3 \\
\%\end{array}$ & $\begin{array}{c}4-6 \\
\%\end{array}$ & $\begin{array}{c}7-10 \\
\%\end{array}$ & $\begin{array}{c}\text { Total } \\
\text { da \% }\end{array}$ & $\begin{array}{c}\text { Média } \\
\text { X }\end{array}$ \\
\hline RH127 Saúde - PCSMO & 0.8756 & 0.8790 & 4 & 11 & 85 & 100 & 8.4 \\
\hline RH131 Recrutamento e seleção & 0.8162 & 0.6381 & 4 & 15 & 81 & 100 & 7.5 \\
\hline RH123 Ambulatório & 0.4254 & 0.6115 & 15 & 15 & 70 & 100 & 7.1 \\
\hline RH136 Vida pessoal & 0.7484 & 0.5138 & 0 & 19 & 81 & 100 & 8.2 \\
\hline
\end{tabular}

Fator 3: Administração de Recursos Humanos (8\%)

\begin{tabular}{|l|c|c|c|c|c|c|c|}
\hline \multicolumn{1}{|c|}{ Variável } & $\begin{array}{c}\text { Comu- } \\
\text { nalidade }\end{array}$ & $\begin{array}{c}\text { Carga } \\
\text { Fatorial }\end{array}$ & $\begin{array}{c}0-3 \\
\%\end{array}$ & $\begin{array}{c}4-6 \\
\%\end{array}$ & $\begin{array}{c}7-10 \\
\%\end{array}$ & $\begin{array}{c}\text { Total } \\
\text { da \% }\end{array}$ & $\begin{array}{c}\text { Média } \\
\text { X }\end{array}$ \\
\hline RH112 T\&D & 0.88 & 0.88 & 8 & 27 & 65 & 100 & 7.0 \\
\hline RH132 Avaliação do desempenho & 0.75 & 0.75 & 15 & 50 & 35 & 100 & 5.6 \\
\hline RH113 Processos e tecnologia & 0.64 & 0.68 & 4 & 12 & 84 & 100 & 7.6 \\
\hline RH114 Comitês den decisão & 0.83 & 0.57 & 11 & 35 & 54 & 100 & 6.7 \\
\hline
\end{tabular}




\subsection{Composição dos fatores}

4.3.2 Gerência de recursos humanos (continuação)

Fator 4: Demandas Legais (7\%)

\begin{tabular}{|l|c|c|c|c|c|c|c|}
\hline \multicolumn{1}{|c|}{ Variável } & $\begin{array}{c}\text { Comu- } \\
\text { nalidade }\end{array}$ & $\begin{array}{c}\text { Carga } \\
\text { Fatorial }\end{array}$ & $\begin{array}{c}0-3 \\
\%\end{array}$ & $\begin{array}{c}4-6 \\
\%\end{array}$ & $\begin{array}{c}7-10 \\
\%\end{array}$ & $\begin{array}{c}\text { Total } \\
\text { da } \%\end{array}$ & $\begin{array}{c}\text { Média } \\
\text { X }\end{array}$ \\
\hline RH121 -SIPAT & 0.76 & 0.76 & 0 & 31 & 69 & 100 & 7.7 \\
\hline RH141 -Convênios comerciais & 0.71 & 0.71 & 15 & 15 & 70 & 100 & 6.8 \\
\hline RH124 Convênio Médico & 0.89 & 0.70 & 8 & 8 & 84 & 100 & 8.3 \\
\hline
\end{tabular}

Fator 5: Administração de Recursos Humanos

\begin{tabular}{|l|c|c|c|c|c|c|c|}
\hline \multicolumn{1}{|c|}{ Variável } & $\begin{array}{c}\text { Comu- } \\
\text { nalidade }\end{array}$ & $\begin{array}{c}\text { Carga } \\
\text { Fatorial }\end{array}$ & $\begin{array}{c}0-3 \\
\%\end{array}$ & $\begin{array}{c}4-6 \\
\%\end{array}$ & $\begin{array}{c}7-10 \\
\%\end{array}$ & $\begin{array}{c}\text { Total } \\
\text { da } \%\end{array}$ & $\begin{array}{c}\text { Média } \\
\text { X }\end{array}$ \\
\hline - RH133 camaradagem/clima & 0.87 & 0.73 & 30.8 & 27 & 42 & 100 & 5.5 \\
\hline - RH134 Carreira & 0.82 & 0.71 & 42.3 & 27 & 31 & 100 & 4.4 \\
\hline - RH135 Salário & 0.82 & 0.67 & 11.5 & 35 & 54 & 100 & 6.3 \\
\hline
\end{tabular}

Fator 6: Reposição de energias ( \%)

\begin{tabular}{|l|l|l|c|c|c|c|c|}
\hline \multicolumn{1}{|c|}{ Variável } & $\begin{array}{c}\text { Comu- } \\
\text { nalidade }\end{array}$ & $\begin{array}{c}\text { Carga } \\
\text { Fatorial }\end{array}$ & $\begin{array}{c}0-3 \\
\%\end{array}$ & $\begin{array}{c}4-6 \\
\%\end{array}$ & $\begin{array}{c}7-10 \\
\%\end{array}$ & $\begin{array}{c}\text { Total } \\
\text { da } \%\end{array}$ & $\begin{array}{c}\text { Média } \\
\text { X }\end{array}$ \\
\hline 142 Tempo livre/lazer & 0.83 & 0.86 & 38 & 27 & 35 & 100 & 4.8 \\
\hline RH126 Refeições & 0.70 & 0.71 & 8 & 11 & 81 & 100 & 7.7 \\
\hline
\end{tabular}




\section{ANEXO 5}

\section{DISTRIBUIÇÃO DAS VARIÁVEIS ESTRUTURA DE GESTÃO DE QVT (COLUNA) NAS UNIDADE CERTIFICADAS (LINHAS)}

\begin{tabular}{|l|l|l|l|l|l|l|l|l|l|l|l|l|l|l|l|l|}
\hline & 1 & 2 & 3 & 4 & 5 & 6 & 7 & 8 & 9 & 10 & 11 & 12 & 13 & 14 & 15 & $\begin{array}{l}\text { indice } \\
(\mathrm{x} 10)\end{array}$ \\
\hline 1 & 0 & 1 & 1 & 1 & 1 & 1 & 0 & 0 & 0 & 0 & 0 & 1 & 1 & 1 & 1 & 6.62 \\
\hline 2 & 1 & 1 & 1 & 1 & 1 & 1 & 1 & 0 &. & 1 & 0 & 1 & 0 & 1 & 1 & 8.98 \\
\hline 3 & 0 & 0 & 1 & 1 & 0 & 1 & 1 & 0 & 1 & 0 & 0 & 0 & 0 & 1 & 1 & 5.77 \\
\hline 4 & 1 & 1 & 1 & 1 & 1 & 1 & 0 & 1 & 0 & 1 & 0 & 1 & 1 & 1 & 1 & 10.4 \\
\hline 5 & 1 & 1 & 1 & 1 & 1 & 1 & 1 & 1 & 0 & 1 & 0 & 1 & 0 & 1 & 1 & 10.4 \\
\hline 6 & 1 & 0 & 1 & 0 & 0 & 0 & 1 & 0 & 0 & 0 & 0 & 0 & 0 & 1 & 1 & 3.75 \\
\hline 7 & 0 & 0 & 0 & 0 & 0 & 0 & 0 & 0 & 0 & 0 & 0 & 0 & 0 & 1 & 1 & 1.06 \\
\hline 8 & 0 & 0 & 1 & 1 &. & 0 & 0 & 0 & 0 & 1 & 0 & 0 & 1 & 1 & 1 & 4.17 \\
\hline 9 & 1 & 1 & 1 & 1 & 1 & 1 & 1 & 1 & 1 & 1 & 1 & 0 & 0 & 1 & 1 & 16.2 \\
\hline 10 & 0 & 0 & 1 & 0 & 0 & 0 & 1 & 0 & 0 & 0 & 0 & 0 & 1 & 1 & 1 & 3.41 \\
\hline 11 & 0 & 1 & 1 & 1 & 0 & 0 & 0 & 0 & 0 & 0 & 0 & 0 & 0 & 1 & 1 & 2.92 \\
\hline 12 & 0 & 0 & 0 & 1 & 0 & 0 & 0 & 0 & 0 & 0 & 0 & 1 & 0 & 1 & 1 & 2.87 \\
\hline 13 & 0 & 1 & 1 & 1 & 1 & 1 & 1 & 0 & 1 & 1 & 0 & 0 & 1 & 0 & 1 & 8.80 \\
\hline 14 & 0 & 0 & 0 & 0 & 0 & 0 & 0 & 0 & 0 & 0 & 0 & 0 & 0 & 0 & 0 & 0.00 \\
\hline 15 &. &. &. &. &. &. &. &. &. &. &. &. &. &. &. &. \\
\hline 16 & 0 & 0 & 1 & 1 & 0 & 0 &. & 0 & 0 & 0 & 0 & 0 & 0 & 1 & 1 & 2.15 \\
\hline 17 & 1 & 1 & 1 & 1 & 1 & 0 & 0 & 0 & 0 & 0 & 0 & 0 & 0 & 0 & 0 & 3.93 \\
\hline 18 & 0 & 1 & 0 & 1 & 1 & 1 & 1 & 0 & 0 & 0 & 0 & 0 & 1 & 1 & 1 & 5.76 \\
\hline 19 & 0 & 0 & 1 & 0 & 0 & 1 & 1 & 1 & 1 & 1 & 0 & 0 & 1 & 0 & 1 & 8.07 \\
\hline 20 & 1 & 1 & 1 & 1 & 1 & 1 & 0 & 0 & 0 & 0 & 0 & 1 & 0 & 1 & 1 & 6.96 \\
\hline 21 & 1 & 1 & 1 & 1 & 1 & 1 & 1 & 1 & 0 & 1 &. & 1 & 1 & 1 & 1 & 11.3 \\
\hline 22 & 0 & 0 & 1 & 1 & 0 & 1 & 1 &. & 0 & & 1 & 0 & 1 & 0 & 1 & 9.09 \\
\hline 23 & 0 &. &. &. & 0 &. &. &. & 0 &. &. &. & 0 &. &. & 0.00 \\
\hline 24 & 0 & 1 & 1 & 0 & 0 & 0 & 0 & 0 & 0 & 0 & 0 & 0 & 0 & 0 &. & 1.30 \\
\hline 25 & 0 & 1 & 0 & 1 & 1 & 1 & 0 & 1 & 1 & 1 &. & 1 & 1 &. & 1 & 10.0 \\
\hline 26 & 0 &. & 1 & 1 & 1 & 1 & 1 & 0 & 1 & 0 & 0 & 0 & 1 & 1 & 1 & 6.03 \\
\hline Tot & 8 & 13 & 19 & 18 & 12 & 14 & 11 & 7 & 5 & 9 & 2 & 8 & 11 & 17 & 21 & \\
\hline
\end{tabular}




\section{ANEXO 6}

\section{INSTITUIÇÕES CERTIFICADORAS DAS EMPRESAS PESQUISADAS}

ABS - ABS Quality Evaluations

BRTÜV (TÜV-CERT)

BSI - British Standats Institution

BVQI - Bureau Veritas Quality International

Comitê Brasileiro de Qualidade - CB- $25^{2}$

DOS - Deutsche Gesellschaft zur Zertifizierung von

Qualitatsmanagementsystemen

DVN - Det Norske Veritas Classification A/S

IBQN - Instituto Brasileiro de Qualidade Nuclear

INMETRO - Instituto Nacional de Metrologia, Normatização e Qualidade Industrial ${ }^{3}$

Lloyd's Register Quality Assurance

TÜV - RWTÜV

UCIEE - União Certificadora da Indústria Eletro-Eletrônica

VANZOLINI - Fundação Carlos Alberto Vanzolini

\footnotetext{
${ }^{2}$ Órgão normativo e informativo de Qualidade da ABNT - Associação Brasileira de Normas Técnicas

${ }^{3}$ INMETRO só certificou até Março de 1995
} 


\section{ANEXO 7}

\section{MATRIZES E RELATÓRIOS ESTATÍSTICOS - SAS}

1. Análise fatorial - $\mathrm{RH}$

2. Análise Fatorial - Funcionários

3. Análise de Conglomerados

4. Análise de correlação - funcionários

5. Análise discriminante

6. Análise de regressão múltipla 